\title{
Um poeta português também do Brasil: \\ Joaquim Nabuco leitor de Camões
}

Adriano Lima Drumond

Orientador: Prof. Dr. Paulo Motta Oliveira

USP - São Paulo

2012 


\title{
Um poeta português também do Brasil:
}

\section{Joaquim Nabuco leitor de Camões}

\author{
Adriano Lima Drumond
}

Orientador: Prof. Dr. Paulo Motta Oliveira

Monografia apresentada ao Programa de PósGraduação em Estudos Literários da Faculdade de Filosofia, Letras e Ciências Humanas da Universidade de São Paulo, como parte dos requisitos para obtenção do título de doutor em Estudos comparados de literaturas de língua portuguesa.

USP - São Paulo 
a José Guilherme Merquior, com cuja obra já planejo um encontro no pós-doutorado. 


\section{AGRADECIMENTOS}

Antes de agradecer, quero esclarecer. Esta tese é fruto de um desespero e de uma felicidade. Meu projeto anterior se propunha a analisar a ideia de decadência da nação portuguesa na narrativa ficcional de Camilo Castelo Branco, em confronto com obras de outros autores: Almeida Garrett, Alexandre Herculano, Júlio Dinis, Antero de Quental e Eça de Queirós (“Mas isso é quase um time de futebol!", disse-me simpaticamente um professor da Casa). Desse modo, eu desenvolveria a pesquisa da minha dissertação, A imagem da nação portuguesa em A queda dum anjo, de Camilo Castelo Branco, defendida em março de 2007 na Faculdade de Letras da UFMG, sob orientação do prof. Dr. Marcus Vinicius de Freitas. Na tese, ampliar-se-ia o corpus de estudo, restringindo-se o foco temático. Nunca me satisfizeram plenamente os termos dessa proposta. Não via, porém, como aprimorá-la a contento. Pesquisava e escrevia como imagino que o fizesse um burocrata alemão: com rigor, mas sem amor. Estava desesperado. Não achava justo comigo mesmo furtar-me, no doutoramento, ao arroubo que me tomara durante o mestrado. Não precisei rezar (agnóstico que sou), nem assinar pactos mefistofélicos (e agnóstico medroso de tais possibilidades), para que surgisse, nel mezzo del cammin desses cinco anos, a solução: adotar para um novo projeto meu interesse pelos estudos camonianos de Joaquim Nabuco, interesse que então já contava algum tempo. Aí estava minha felicidade... ou pelo menos a felicidade da cabeça. Era o bastante para comemorar muito. A felicidade do estômago jamais foi difícil. E a do coração... é sempre, dentre todas, a mais complicada, especialmente para pessoas como eu.

Dito isso, agradeço -

ao prof. Dr. Paulo Motta Oliveira: não apenas orientador e amigo, mas, sobretudo, um orientador-amigo, que compreendeu perfeitamente meu temperamento intelectual oscilante, 
tão sujeito a marasmos e intempéries. Se navegar é preciso, sem ser preciso chegar às Índias, seu auxilio foi essencial para que a nau não naufragasse;

aos professores Doutores Marcia Arruda Franco e Ricardo de Souza Carvalho, que, na qualificação, me deram preciosas sugestões bibliográficas e estruturais às quais acatei e que, ao lado do encorajador incentivo, garantiram melhor encaminhamento para este trabalho;

aos professores Doutores José Américo Miranda e Marcos Rogério Cordeiro, as respostas prestativas a minhas consultas sobre o tema deste trabalho;

a meus pais e minha irmã: porque à família como essa sempre é ocasião de agradecer;

a Aline Dias Leal: companheira que entendia e não entendia minhas ausências afetivas em razão desta pesquisa. Mas fosse como fosse, não deixou de estar junto de mim;

a Luciene Marie Pavanelo: nem José Dias se contentava, por the parecer pouco, chamá-la dulcíssima amiga. Foi ela a primeira pessoa com quem conversei e consultei sobre a mudança de projeto. Seu incentivo também exige mais que o superlativo obrigadíssimo;

a Ana Luísa Patrício Campos de Oliveira, o carinho, o humor, a amizade, as fotos de Praga... tanta coisa que comprova que Nelson Rodrigues estava completamente equivocado a respeito dos paulistas;

aos colegas Alexandre Paz Almeida, Carla Patrícia Silva do Nascimento, Evangelita Carvalho da Nóbrega, Gilvan Cordolino de Lima e Valdeney Lima da Costa, meus amigos do Nordeste, que me permitem me sentir em casa, mesmo onde não gosto de morar;

a André Yukio Kamei Mori, Leonardo Barbosa de Almeida Coelho e Leonardo Rodrigo de Oliveira Ramos: simplesmente os irmãos que não tive, nos amigos que tenho o privilégio de ter reconhecido, com quem estabeleço diálogos sempre fundamentais para minha formação intelectual e afetiva;

a Ludwig van Beethoven: num período de momentos tão complicados, em tantos setores da vida, distante na maior parte dos anos, desde 2009, da família, dos amigos, de Belo 
Horizonte, cidade onde nasci intelectualmente, só mesmo a música do maior de todos os compositores para tornar possível a existência. 


\section{RESUMO}

Nesta monografia, elegeram-se objeto de estudo os textos que Joaquim Nabuco escreveu sobre Camões, analisados numa perspectiva que privilegiou a articulação entre o assunto literário e a questão da nacionalidade. Parcela muito pouco conhecida da obra nabucoana, o ensaio Camões e Os Lusíadas, publicado em 1872, o discurso pronunciado por ocasião do tricentenário de morte do poeta quinhentista e as conferências "The place of Camoens in literature", "Camoens, the lyric poet" e "The Lusiads as epic of love", pronunciadas no biênio 1908-09, constituem registro de como o autor pernambucano pensou a cultura e a identidade brasileiras frente à história colonial e à presença da literatura portuguesa no contexto oitocentista no País, em período de consolidações nacionalistas. $\mathrm{O}$ fato é que a poesia camoniana motivou Nabuco a afirmar os laços culturais entre ex-colônia e ex-metrópole, propondo um Camões luso-brasileiro, em 1872 e 1880 (o primeiro desses anos, também um centenário, o de publicação d'Os Lusíadas), e, em 1908-09, um Camões - podemos dizer pan-americanista, ou a serviço da propaganda monroísta, causa abraçada pelo então embaixador do Brasil nos Estados Unidos. Esta monografia também discute as concepções literárias de Joaquim Nabuco, especialmente no que tange ao exercício da crítica, bem como levanta hipóteses a partir das quais se procurou explicar o porquê de o abolicionista ter escolhido Camões como tema de certa recorrência e importância dentro de sua dedicação à literatura.

PALAVRAS-CHAVE: Joaquim Nabuco; Camões; Identidade nacional; Crítica literária; Brasil. 


\begin{abstract}
This monograph analyses the texts that Joaquim Nabuco wrote about Camoens, in a perspective in which the literary subject and the nationality question are set in dialog. The book Camões e Os Lusíadas, published in 1872, the speech, which has celebrated the third centenary of Portuguese poet's death, and the speeches "The place of Camoens in literature", "Camoens, the lyric poet" and "The Lusiads as epic of love", which were spoken in 1908-09, are a register of how the author has thought about Brazilian culture and identity in the face of the colonial history and presence of Portuguese literature in $19^{\text {th }}$ century Brazilian context and in a period of emergence of nationalist movements. In fact Camoens's poetry motivated Nabuco to assert the cultural ties between Portugal and Brazil, by presenting a Luso-Brazilian image of Camoens in 1872 and 1880 (the first of these years was the third centenary of publication of Os Lusíadas) and a pan-americanist image of him in 1908-09, which is, a Camoens in service of monroism, foreign policy that the Brazilian ambassador did stand up for. This monograph discusses Joaquim Nabuco's literary thought, too, especially when it comes to criticism, and proposes hypothesis to explain why did the abolicionist choose Camoens as an important subject of his dedication for literature.
\end{abstract}

KEYWORDS: Joaquim Nabuco; Camoens; National identity; Criticism; Brazil. 


\section{CAPÍTULO 1:}

Camões no Portugal e no B rasil do século XIX .............................................. 20

1.1) Considerações preliminares ................................................................... 21

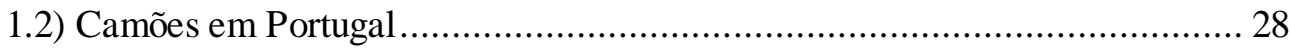

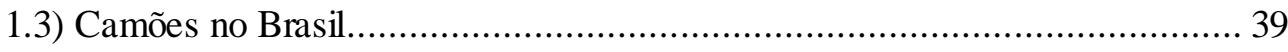

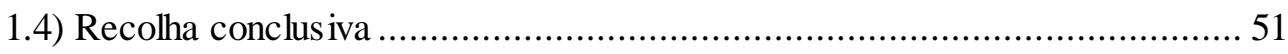

\section{CAPÍ́tulO 2:}

Um Camões luso-brasileiro: a rece pção nabucoana em 1872 e 1880 ................ 56

2.1) Camões e Os Lusíadas ............................................................................ 57

2.1.1) Considerações preliminares .............................................................. 57

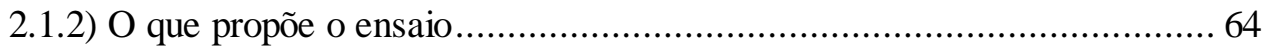

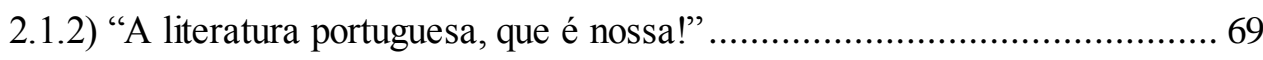

2.2) O discurso "Terceiro centenário de Camões"............................................ 86

2.2.1) Considerações preliminares ............................................................ 86

2.2.2) O que propõe o discurso .............................................................. 98

2.2.3) “Os Lusíadas nos pertence também um pouco" ....................................104

\section{CAPí́tulo 3:}

Um Camões pan-ame ricanis ta: a recepção nabucoana em 1908-09.................113

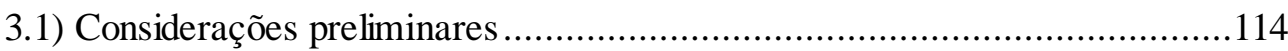

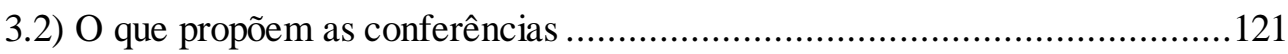

3.3) Um Camões pan-americanista? ............................................................140

\section{CAPí́tulo 4:}

Joaquim Nabuco leitor de Camões: o estigma da contradição ........................156

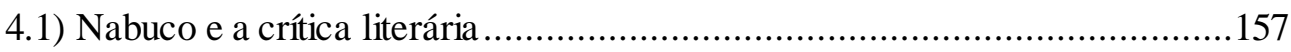

4.2) Por que Camões? ......................................................................... 175 
Porque pensamos bem de nós mesmos, mas não esperamos ser capazes de algum dia fazer um esboço de um quadro de Rafael ou a cena de um drama de Shakespeare, persuadimo-nos de que a capacidade para isso é algo sobremaneira maravilhoso, um acaso muito raro ou, se temos ainda sentimento religioso, uma graça dos céus. É assim que nossa vaidade, nosso amor-próprio, favorece o culto ao gênio: pois só quando é pensado como algo distante de nós, como um miraculum, o gênio não fere [...].

Humano, demasiado humano, F. Nietzsche 
INTRODUÇÃO 
Se um repórter de TV saísse às ruas de uma capital brasileira e perguntasse às pessoas se conhecem Joaquim Nabuco, caso a resposta fosse positiva, ${ }^{1}$ o mais comum decerto seria associarem-no ao movimento abolicionista. Numa percentagem bem menor, um ou outro transeunte poderia dizer que se trata do autor de Minha formação ou de Um estadista do império. E nem digamos quantos, mas quem responderia ter sido também um comentarista da vida e obra de Luís Vaz de Camões?

Das ruas para dentro dos muros universitários, o resultado revelasse talvez mudança percentual relativa à primeira e à segunda respostas, mas com certeza não quanto à terceira. Em muitos casos, não por descaso para com o legado de Joaquim Nabuco, e sim porque os estudos camonianos se situam realmente num lugar periférico de sua opera omnia. O fato se reflete na recepção crítica desses trabalhos. Há muitos textos que comentam, analisam essa parcela da obra nabucoana, valorizando-a, protestando contra o esquecimento a que a posteridade com muita pressa as relegou, mas nada que em importância e volume atinja o interesse que o Nabuco abolicionista e autor de Minha formação, Um estadista do império, $O$ abolicionismo vem despertando no meio acadêmico.

É sintomático o fato de que boa parte dos que escreveram e falaram no século XX sobre os estudos camonianos de Nabuco tenha aparecido em datas comemorativas. ${ }^{2}$ Caso da conferência de Antônio Carneiro Leão, "Nabuco - rapsodo de Camões", ${ }^{3}$ de 1949, ano em que se completava um século do nascimento do abolicionista; caso da conferência de Américo

\footnotetext{
${ }^{1}$ Em artigo veiculado pelo Diário de Pernambuco, a 3 de setembro de 1978, Gilberto Freyre desabafava: "Fui dos que se horrorizaram com a revelação, através de imediato inquérito jornalístico, dos muitos recifenses de hoje que não sabem quem foi Joaquim Nabuco." (FREYRE, 2010, p.287)

2 Notável exceção é o trabalho de Carlos Daghlian Os discursos americanos de Joaquim Nabuco, fruto de dissertação de título Joaquim Nabuco: American speeches, defendida na Pepperdine University de Los Angeles, a 1965. O autor aí tinha em vista a carência de fortuna crítica a respeito dos textos que o embaixador brasileiro em Washington proferiu. A análise de Carlos Daghlian pauta-se pela perspectiva da retórica e detém-se na figura do orador como princípio de construção textual. Ou seja, não é propósito de Daghlian abranger, em sua análise, o ensaio de 1872 e o discurso de 1880, nem privilegiar as três conferências camonianas, mas todas as dezoito pronunciadas por Nabuco.

${ }^{3}$ In: Nabuco e Junqueiro. Lisboa: Lello \& Irmão, 1953. pp.1-35.
} 
da Costa Ramalho, "Joaquim Nabuco e Camões", ${ }^{4}$ e do ensaio de Hernâni Cidade "Como o meu camonismo se sente apoiado em Joaquim Nabuco",5 ambos de 1972, quando se comemoraram os quatro séculos da edição princeps d'Os Lusíadas; e do estudo prévio de Maximiano de Carvalho e Silva, ${ }^{6}$ constituído por páginas que introduzem a edição de 1980 do discurso proferido havia cem anos pelo autor de Balmaceda. Assim sendo, chama a atenção a confissão expressa em um desses textos referidos: "Causa estranheza verificar, na bibliografia de trabalhos recentes, quando não a omissão completa, a citação apenas parcial e inexpressiva do que publicou o grande escritor [pernambucano sobre Camões]"7. Mas se os estudos camonianos de Joaquim Nabuco importam tanto quanto são esquecidos ou desprezados, por que comentá-los quase apenas em ocasiões comemorativas? A pergunta desencadeia outra: a defesa e divulgação dessa parte da obra nabucoana não decorreriam, em grande medida, de reverência à importância histórica de seu autor, assim como do valor de outros trabalhos seus, reconhecidamente importantes, como Minha formação, Um estadista do império e $O$ abolicionismo?

Seja como for, este trabalho não teve a pretensão de reverter o quadro que esboçamos acima. Objetivar fazer o Joaquim Nabuco leitor de Camões tornar-se tão conhecido e reconhecido quanto os demais Nabucos seria levar a cabo uma pesquisa sob a proteção do escudo de Mambrino. E acreditamos: pudemos até ter pecado por quixotismo em outros aspectos desta tese, mas não por essa pretensão. Está fora de nosso foco qualquer procura de argumentos e conclusões que valorizem ou desvalorizem esses estudos de Nabuco (não obstante nossa eleição do tema, necessariamente, valorizá-los, quer queira, quer não).

\footnotetext{
${ }^{4}$ In Estudos camonianos. Coimbra: Instituto de Al ta Cultura, 1975. pp.101-123.

${ }^{5}$ In Cultura. Rio de Janeiro, MEC, ano 2, no 6, abril-junho. 1972. pp.66-71.

6 In Camões: discurso pronunciado a 10 de junho de 1880 por parte do Gabinete Português de Leitura. Rio de Janeiro: Biblioteca Nacional, 1980. pp.7-26.

${ }^{7}$ CARVALHO E SILVA, 1980, p.21.
} 
E o que pretendemos com esta monografia? Primeiramente, é preciso dizer algumas palavras acerca da recepção de Camões no período no qual o ilustre pernambucano produziu seus trabalhos sobre o quinhentista português, que consistem num ensaio de 1872, um discurso proferido em 1880 e três conferências pronunciadas, em inglês, em 1908 e 1909. E foi esse um período, afinal, de centenários, de nacionalismos, de imperialismos, analisado por Eric Hobsbawm, que o denominou de a era dos impérios. Segundo o historiador, a era dos impérios principia em 1875, consolidado o capitalismo como modo de produção no Ocidente - resultado de uma outra era, a do capital - e termina em 1914, ano que, com a eclosão da Primeira Grande Guerra, encerra "uma das 'rupturas naturais' mais inegáveis da história". 8 E se o costume de se comemorar os centenários teria surgido "entre o centésimo aniversário da Revolução Americana (1876) e o da Revolução Francesa (1889)", ${ }^{9}$ é "no período de 1880 a 1914 [que] o nacionalismo avançou dramaticamente". ${ }^{10}$ Mas outro fato - o "maior do século XIX" - requer menção para compreendermos um pouco melhor, nesta introdução, o sentido da era dos impérios de Hobsbawm: trata-se da "criação de uma economia global única, que atinge progressivamente as mais remotas paragens do mundo", 11 fenômeno cujo código de 1875 a 1914 se traduziria na postura imperialista por parte das maiores potências econômicas, tradicionais como a Inglaterra e a França, e novas como a Alemanha, os Estados Unidos e o Japão.

A recepção oitocentista de Camões (adotemos como fim do século XIX o ano de 1914) foi profundamente marcada por essa conjuntura. Os dois centenários camonianos - em 1872, o de publicação d'Os Lusíadas; em 1880, o da morte do poeta; mas, sobretudo este último, plenamente inserido na era dos impérios - foram comemorados pelo mundo luso-

\footnotetext{
${ }^{8}$ HOBSBAWM, 2003, p.19.

${ }^{9}$ HOBSBAWM, 2003, p.29.

10 HOBSBAWM, 2003, p.203.

${ }^{11}$ HOBSBAWM, 2003, p.95.
} 
brasileiro. Com efeito, mais do que 1872, o ano de 1880 arrebatou os ânimos patrióticos dos portugueses, muito graças ao empenho da campanha meio literária, meio política do republicano Teófilo Braga, já então reconhecido camonólogo. A data não deixaria de comover o orgulho brasileiro, tendo sido aqui festejada em várias províncias, com a adesão de eminências políticas e intelectuais, mas também de setores populares da sociedade. E, efetivamente, tanto aquém quanto além-mar, nessa época, Camões tinha um sentido nacional.

Todavia, não é curioso que, num ano em que o Brasil poderia comemorar o meio século de sua independência, proclamada em 1822, um brasileiro - Joaquim Nabuco escrevesse ensaio de homenagem a poeta, ao considerado maior poeta da ex-metrópole?

Nesse período (2010-2012) de contato com os textos nabucoanos sobre Camões, vários temas nos instigaram reflexões que poderiam resultar em artigos ou mesmo outras monografias. O novo lugar da mulher na sociedade ocidental entre fins do século XIX e começo do XX é um desses temas. A homerização de Camões - processo que se verifica em boa parte da crítica oitocentista europeia e luso-brasileira - também. O olhar de Joaquim Nabuco sobre a mitologia clássica, outro tema. Nossa escolha aqui foi de abordagem que aponta para a necessidade de uma articulação da matéria literária com a questão da nacionalidade. Pois algo que definitivamente perseguiu Nabuco, no trato público com a vida e obra camonianas, foi a tensão entre a condição de ser brasileiro (em momento de afirmações nacionais, ou nacionalistas) e a eleição de um poeta (ou de o poeta) da ex-metrópole.

Joaquim Aurélio Nabuco de Araújo (1849-1910) escreveu textos sobre Camões, destinados ao público leitor e/ou ouvinte, em três momentos bem distintos de sua carreira de homem que se dedicou intensamente à vida intelectual, política e diplomática. O ensaio Camões e Os Lusíadas aparece em 1872, motivado pelo terceiro centenário dessa epopeia. $\mathrm{O}$ autor contava 23 anos e manifestava sede de nomeada por méritos próprios, pretendendo 
assim escapar à sombra do pai, senador do Império. Nabuco, a essa altura, já se fizera celebrado em julho de 1869, num comício do partido liberal, em Recife, tendo irrompido em meio aos ânimos exaltados pela desavença, realizando a proeza oratória de conclamar os correligionários à necessária união, episódio a que se acrescenta o da bem-sucedida defesa de um escravo assassino, encampando nisso dupla batalha: contra a escravidão e contra a pena de morte. Durante o curso de Direito, frequentado como aluno primeiro em São Paulo, depois em Recife, conforme a tradição acadêmica brasileira, Nabuco chegou a escrever textos literários, mas sem the reconhecerem, tampouco em si mesmo reconhecer, talento efetivo. Camões e Os Lusíadas foi a estreia em volume, ${ }^{12}$ primeiro manifesto - sobretudo no que diz respeito à introdução do livro - do autor como digno representante da chamada Geração de 70 brasileira.

Oito anos mais tarde, Joaquim Nabuco profere, a convite do Real Gabinete Português de Leitura do Rio de Janeiro, discurso por ocasião das comemorações do tricentenário de morte de Camões. Agora era deputado, e já estava célebre por ter se engajado na causa abolicionista. A instituição cultural lusitana reconhecia-lhe, pois, o interesse pelo poeta que tomavam como um dos símbolos da glória de Portugal. O texto, muito aplaudido pelos que o ouviram, viria a ser publicado em volume pela editora Leuzinger, e posteriormente coligido, com importantes alterações, em Escritos e discursos literários, de 1901.

Por fim, as três conferências pronunciadas nos anos de 1908 e 09, período no qual Joaquim Nabuco trabalhava como embaixador do Brasil em Washington. As diferenças contextuais entre o autor pernambucano do ensaio de 1872 e 1880 e o de "The place of Camoens in literature", "Camoens, the lyric poet" e "The Lusiads as epic of love" são numerosas e importantíssimas. A mudança de século, no âmbito brasileiro, trazia já dos últimos anos do oitocentos a mudança de regime de governo e um longo ostracismo político a

\footnotetext{
${ }^{12} \mathrm{Na}$ verdade, o jovem pernambucano tinha planejado publicar antes outra obra, de outro cunho, intitulada $A$ escravidão, que não concluiu, e que viria apenas a público, em volume, em 1988, pela editora Nova Fronteira.
} 
que Nabuco, fiel à monarquia, se impôs, refugiando-se numa considerável produtividade historiográfica e literária. O exercício no alto cargo diplomático implicava a adesão plena por parte de Joaquim Nabuco à república, e, ademais, ao engajamento numa nova causa, que substituiria a anterior - o abolicionismo -, na qual fora vitorioso: era essa nova causa o panamericanismo monroísta, ideário com que os Estados Unidos procurava legitimar seu imperialismo no Continente americano.

A introdução de Camões e Os Lusíadas, o discurso de 1880 e as três conferências de 1908-09 constituem preciosos testemunhos de como Joaquim Nabuco relacionou o intuito de interpretar e divulgar Camões com questões voltadas à nacionalidade, portuguesa e brasileira. No primeiro texto, o autor pernambucano chega a defender a não-separação entre a produção literária do Brasil e a literatura de Portugal, que, por conseguinte, nos pertenceria. No referido discurso, outro é o posicionamento de Nabuco, mas, de qualquer forma, ele ainda se vê às voltas com a questão da nacionalidade, dado que integrantes da comunidade portuguesa residente no Brasil contestaram-lhe a função honrosa - por não ser português - de discursar em data que ficaria designada além-mar como o Dia da Raça. Já as três conferências pronunciadas nos EUA, em inglês, parecem não se dissociar do cargo de embaixador do Brasil em Washington, que Joaquim Nabuco exercerá empunhando com entusiasmo a bandeira do pan-americanismo monroísta. Ora, Nabuco objetivará com essas solenidades o estreitamento de laços entre brasileiros e norte-americanos, divulgando a cultura não brasileira, mas luso-brasileira, da qual o grande poeta seria Camões.

Mas por que Camões? O que essa escolha nos diz das atividades intelectuais do ilustre pernambucano e do Brasil em geral na era dos impérios? Neste trabalho, dispomo-nos a considerar precisamente tais questões. 
Nossa monografia divide-se em quatro capítulos. No primeiro (“Camões no Portugal e no Brasil do século XIX”), rastreamos a imagem e recepção de Camões do século XIX especialmente a partir de meados dessa centúria - até princípios do $\mathrm{XX}$, contextualizando, no âmbito luso-brasileiro, o interesse de Joaquim Nabuco pelo poeta quinhentista. Obviamente, ativemos, para a constituição desse panorama, a alguns poucos, mas significativos autores. Dentre os portugueses, constam em destaque os nomes de Almeida Garrett, Teófilo Braga, Oliveira Martins, Antero de Quental, Eça de Queirós e Cesário Verde; dentre os brasileiros, Álvares de Azevedo, Casimiro de Abreu, Machado de Assis, Miguel Lemos e Afrânio Peixoto. O segundo capítulo (“Um Camões luso-brasileiro: a recepção nabucoana em 1872 e 1880”) destina-se à análise do livro Camões e Os Lusíadas, do qual a introdução será o foco, e do discurso por ocasião do tricentenário de morte do poeta português; o terceiro capítulo (“Um camões pan-americanista: a recepção nabucoana em 1908-09”), à análise das três conferências pronunciadas nos Estados Unidos. Nesses dois capítulos, centrais de nosso trabalho, é que discutimos com maior ênfase como os textos camonianos de Nabuco lidam com a questão de um autor/orador/conferencista brasileiro tratar de um poeta português, apropriado pela nacionalidade que a ex-colônia se esforçava por afirmar. O quarto capítulo (“Joaquim Nabuco leitor de Camões: o estigma da contradição") estrutura-se em duas partes: a) "Nabuco e a crítica literária", que contextualiza e problematiza os estudos camonianos de Nabuco na esfera da crítica literária; e b) "Por que Camões?", seção que objetiva levantar hipóteses que esclareçam a escolha do autor pernambucano em tornar pública sua admiração e conhecimento acerca do poeta d'Os Lusíadas, em diferentes e importantes etapas de sua vida. Em ambas as partes desse último capítulo de nossa monografia, discorreremos como a contradição perpassa a relação de Joaquim Nabuco com a poesia camoniana.

Gostaríamos ainda, e com isto finalizamos esta introdução, de informar que infelizmente não dispomos de acesso a mais adequada biblioteca para levar a cabo esta 
pesquisa. Quando nos decidimos pelo tema, dali a pouco devíamos residir numa pequena cidade ao sul de um estado nordestino, chamada Bom Jesus, onde ainda hoje exercemos o cargo de professor do quadro efetivo da Universidade Estadual do Piauí (UESPI). Grande parte de nossa bibliografia, editada unicamente no século XIX, e, portanto raridade, foi adquirida via internet. Mas não tivemos o recurso necessário para compra de outros importantes títulos, dentre os quais Camões e Os Lusíadas, de Francisco Leoni, de 1872, Camões, de Afonso Celso Jr., O centenário de Camões no Brasil. Portugal em 1580. O Brasil em 1880, ambos do mesmo ano do tricentenário da morte do quinhentista português, e os volumes do Visconde de Juromenha. E visto que poderíamos ter viajado para localidades que ofertariam bons ou razoáveis acervos, arrependemo-nos de não ter solicitado afastamento para conclusão do doutorado. 


\section{CAPÍtUlo 1:}

CAMÕES NO PORTUGAL E NO BRASIL

DO SÉCULO XIX 


\section{1) Considerações preliminares:}

Dificilmente se poderia pensar na imagem de Camões e na interpretação de sua obra, produzidas na segunda metade do oitocentos e nas primeiras décadas do novecentos, tanto em Portugal quanto no Brasil, sem uma mínima compreensão prévia de como isso se deu na primeira metade do século XIX. No caso português, a data que definitivamente marca o início da presença renovada da figura e da poesia camonianas, no imaginário luso-brasileiro, é o ano de 1825, quando Almeida Garrett publica o livro Camões, com o qual, segundo entendimento tradicional da historiografia literária, o romantismo estreia nas letras do país ibérico. No caso do Brasil, onde esse movimento só começará cerca de uma década mais tarde, publicado Suspiros poéticos e saudades, de Gonçalves de Magalhães, o poeta quinhentista, compreensivelmente, não constituiu alvo de tão amplo e exaltado interesse, como ocorria além-mar. Compreensivelmente porque o romantismo brasileiro teve por projeto hegemônico a afirmação da autonomia cultural de um país recém-independente. Dentro dessa perspectiva política, nada menos favorável à realização de tal projeto do que voltar as atenções, que se deviam concentrar na formação de uma literatura nacional, para um autor da ex-metrópole. Mas a questão não é tão simples assim. Não obstante o diagnóstico de lusofobia no romantismo brasileiro, cá houve vozes destacáveis que expressaram, de forma contundente, admiração e, por vezes, até preocupação de ordem crítica, pela figura e obra de Camões. Disso noticiam, dentre outros trabalhos anteriores, publicados alguns já no século XIX, “Camões e o Brasil” (1924), de Afrânio Peixoto, Camões e a poesia brasileira (1972), de Gilberto Mendonça Teles, e Camões e a literatura brasileira (1973), de Elia Hamilton. Aliás, Tasso da Silveira e Alceu Amoroso Lima destacaram também a disseminada ressonância camoniana em todo o percurso, particularmente, da poesia escrita no Brasil. O primeiro 
afirmara haver "superabundantemente Camões em nossa poesia"; ${ }^{13}$ o segundo, que o "maior poeta da língua portuguesa deixou reflexos do seu gênio em todas as nossas escolas literárias, do Classicismo de um Bento Teixeira ao Modernismo de um Augusto Schmidt, da geração de 1930, ou de um Geir Campos, da de 1945". ${ }^{14}$

Com efeito, encontramos, nas décadas iniciais do século XIX, no Brasil, numerosas manifestações de apreço poético à obra camoniana, salvo uma e outra crítica negativa, como a formulada por Gonçalves de Magalhães, em prefácio à segunda edição de A confederação dos Tamoios. $^{15}$ As gerações seguintes da poesia de nosso romantismo também se revelaram leitores e admiradores da obra camoniana. Em Gonçalves Dias, Álvares de Azevedo, Casimiro de Abreu, Fagundes Varela e Castro Alves, verificaríamos vestígios desse "culto a Camões". 16

Já antes de 1825, Camões e sua obra, sobretudo a épica, haviam conquistado projeção nas mais diversas paragens europeias, principalmente, no decorrer das últimas décadas do século XVIII e no início do XIX. Os Lusíadas, àquela altura, era integral ou parcialmente traduzido para o francês, inglês, alemão, holandês, dinamarquês... Maria Aparecida Ribeiro dá notícia de uma peça de 1808 inspirada em Camões, ${ }^{17}$ escrita por autor conterrâneo de Hamlet, e Camilo Castelo Branco de uma outra, do príncipe russo Elim Mestscherski. ${ }^{18}$ Ferdinand Denis, que se dedicou a pesquisar e divulgar a cultura luso-brasileira, também se rendeu literariamente à temática, tendo legado a peça Camões e José Índio, publicada em Paris poucos meses antes do poema de Almeida Garrett. Lord Byron, embora chamasse os portugueses de "Poor, paltry slaves", na estrofe XVIII do primeiro canto de Childe Harold's pilgrimage, escreveu soneto dedicado ao poeta quinhentista. Em Portugal, Camões inspira até

\footnotetext{
${ }^{13}$ SILVEIRA apud TELES, 1976, p.87.

${ }^{14}$ LIMA apud ELIA, 1973, p.15.

${ }^{15}$ Cf. TELES, 1976, p.93-94.

${ }^{16}$ Cf. TELES, 1976, p.129.

${ }^{17}$ Cf. RIBEIRO, 1987, p.627.

${ }^{18}$ Cf. CASTELO BRANCO, 1989, p.1095.
} 
em outras artes que não a literária; podemos mencionar, a esse respeito, obras musicais, telas (a do pintor português e liberal Domingos Sequeira, por exemplo) e uma intenção de edificar, em Portugal, monumento em homenagem ao autor d'Os Lusíadas - intenção esta, segundo José-Augusto França, motivada pela grandiosa e luxuosa edição do poema épico de 1817, custeada pelo Morgado de Mateus, em Paris. ${ }^{19}$ Também na esfera política a presença de Camões se fazia sentir: nele, os entusiastas da Revolução do Porto de 1820 viam "uma espécie de garantia da 'regeneração' e, ao mesmo tempo, um símbolo da pátria martirizada". ${ }^{20}$ Para José-Augusto França, o interesse europeu tardo-setecentista e oitocentista por Camões explica-se por dois fatores básicos: um de caráter literário (episódios d'Os Lusíadas como o de Inês de Castro) e outro de caráter biográfico (“a vida dolorosa do próprio Camões, poeta e aventureiro, homem de cultura e de experiência vivida, alma apaixonada de ingrato destino"21). Tudo isso falaria diretamente às sensibilidades pré-romântica e romântica europeias. Sobre o assunto, Eduardo Lourenço destaca a drástica mudança paradigmática realizada pelo romantismo em relação à episteme clássica: ${ }^{22}$

Se não foi o Romantismo que inventou a Literatura, modificou por completo sua noção. De realidade de ordem mais ou menos ornamental, atividade destinada a embelezar a vida, ou servir-lhe com verossimilhança de espelho, a obra literária - a grande, a verdadeira obra literária - transmudou-se em visão do mundo, espelho da aventura da Humanidade em busca do absoluto. $^{23}$

\footnotetext{
${ }^{19}$ Cf. FRANÇA, 1999, p.48.

${ }^{20}$ FRANÇA, 1999, p.47.

${ }^{21}$ FRANÇA, 1999, p.50.

${ }^{22}$ A propósito, em texto sobre Camões, João Adolfo Hansen esclarece: “Nem sempre a ficção foi literatura, que é uma invenção relativamente recente, datada do final do século XVIII; e nem sempre a leitura literária de poesia, como leitura que refaz a invenção de um ato de fingir, opera sobre textos originalmente inventados como textos literários. No mundo de Camões, a poesia era certamente ficção, mas não era literária". (HANSEN, 2005, p.163)

${ }^{23}$ LOURENÇO, 1999, p.54.
} 
Nessa nova configuração de paradigma, em que a arte se diviniza em decorrência de o próprio autor tornar-se "o deus da sua obra, sujeito e objeto dela", ${ }^{24}$ uma vez que, nesse momento, Deus "perdera a sua visibilidade, a sua presença, como referência obrigatória do imaginário do homem ocidental", ${ }^{25}$ não apenas os artistas e poetas são românticos: romantizam-se os grandes homens do passado, que teriam ocupado "o lugar vago pela ausência do Deus vivo [...], precursores de uma angústia existencial profunda, mas também os que tiveram um destino maldito por causa do seu gênio, incompatível com a ordem do mundo que os rodeia". ${ }^{26}$ Sendo assim, "destinos como o de Camões, de Tasso ou de Cervantes adaptam-se perfeitamente aos critérios e às exigências do novo olhar literário". ${ }^{27}$ No entanto, pontua Lourenço, "a lenda biográfica [camoniana] existia desde o século XVII sem que tivesse tido semelhante conseqüência" 28 e Os Lusíadas, com seu "caráter clássico" de obra aparentemente "mais virada para o passado que para o futuro", a narrar uma aventura "por demais particularista", estruturada num "fantasioso greco-latino" pouco ou nada afeito ao "maravilhoso propriamente romântico" dificultariam o surgimento de tal atração que o romantismo europeu em geral sentiu pela obra camoniana. ${ }^{29}$ O que nem teriam alcançado episódios como os de Inês de Castro e o do Adamastor. Eduardo Lourenço, então, considera:

Sob a arquitetura inegavelmente clássica de um canto em que se misturam, sem perda das suas cores originais, a luz de uma Renascença crepuscular e o claro-escuro do Barroco, autores como Chateaubriand, Schlegel ou Ludwig Tieck foram sensíveis não apenas à exaltação de uma aventura que evoca $o$ sentido do esforço humano na sua batalha contra o desconhecido, mas igualmente à presença, estranha numa epopéia de perfil clássico, do poeta, com a sua voz grave de herói extenuado, com a sua indignação perante a arbitrariedade da sociedade e dos poderosos, com a sua angústia, tão moderna, perante o desconcerto da História e do Tempo, sem falar da

\footnotetext{
24 LOURENÇO, 1999, p.54.

${ }^{25}$ LOURENÇO, 1999, p.54.

${ }^{26}$ LOURENÇO, 1999, p.55.

27 LOURENÇO, 1999, p.55.

${ }^{28}$ LOURENÇO, 1999, p.55-56.

29 LOURENÇO, 1999, p.56.
} 
vertigem erótica que perpassa nalgumas das mais famosas estrofes do poema. Nem o fervor patriótico, elevado à categoria de paixão, lhes desagrada, pois a alma romântica enraíza-se no particular, no chão natal, e não numa universalidade abstrata. ${ }^{30}$

Sendo assim, segundo Lourenço, se a "lenda biográfica [camoniana]" existia havia muito, a "nova sensibilidade" é que a valorizará de maneira que o não poderia ter feito o classicismo. Quanto aos episódios famosos de Inês e do Adamastor, dá-se o mesmo: sempre pertenceram a Os Lusíadas, porém a sensibilidade pré-romântica e romântica lhes conferirá outro peso literário-emocional impensável no período clássico. $\mathrm{Na}$ verdade, ao fim e ao cabo, Lourenço endossa a explicação sobre a "adoção deste poema pela nova sensibilidade", ao afirmar que Chateaubriand, Schlegel e Tieck "foram sensíveis" a elementos desconsiderados pelo olhar clássico, como o caráter individual do enunciador, o tom revoltoso e lamentoso de sua voz em determinadas passagens, além da carga patriótica tão cara ao romantismo, que nascia juntamente com a modernidade do fenômeno da nação.

Cumpre dizer aqui algumas palavras sobre esse tema que teve forte, íntimo vínculo com a recepção crítica e criativa de Camões, não apenas no decorrer do século XIX, mas também em boa parte do XX. Os textos camonianos de Joaquim Nabuco enquadram-se quase perfeitamente no que Eric Hobsbawm intitula de a era dos impérios, com princípio em 1875 e término em 1914. Trata-se de período em que, após a consolidação da ideia de nação como paradigma político-cultural entre fins do setecentos e as primeiras décadas do oitocentos, ocorre, principalmente a partir da década de 1870, um sensível aumento do número de movimentos nacionalistas na Europa. ${ }^{31}$ A questão acabaria por merecer a atenção de Ernest Renan (diga-se de passagem, autor de profunda e duradoura influência no pensamento nabucoano). E, assim, em maio de 1882, Renan pronuncia na Sorbonne conferência que

\footnotetext{
${ }^{30}$ LOURENÇO, 1999, p.56-57.

${ }^{31}$ Cf. HOBSBAWM, 2003, p.207.
} 
estaria destinada a constituir marco na história da problematização e teorização do assunto: “Qu'est-ce qu'une nation?” (“'O que é uma nação?”).

Contrariamente ao que pressupunha o senso comum informado pelo discurso do nacionalismo - a saber, a antiguidade ou mesmo o a-historicismo da nação, étnica e culturalmente homogênea e estática -, a conferência de 1882 ensinava: 'L'oubli, et je dirai même l'erreur historique, sont un facteur essentiel de la création d'une nation, et c'est ainsi que le progrés des études historiques est souvent pour la nationalité un danger.,32 Compreendida, portanto, como constructo localizado na história e, afinal, de data recente, Renan observava ainda: 'Les nations ne sont pas quelque chose d'eternel. Elles ont commencé, elles finiront.",33

E o que teria havido antes desse fenômeno moderno? É que o Adriano Moreira esclarece nestes termos, tomando a França como caso exemplar: "na Idade Média, um homem deveria sentir-se primeiramente cristão, depois burguinhão, e finalmente francês, em sentido inteiramente diferente do actual", ${ }^{34}$ bem como Lord Acton, em texto de 1862:

No antigo sistema europeu, os direitos das nacionalidades não eram reconhecidos pelos governos nem afirmados pelo povo. O interesse das familias reinantes, e não os das nações, regia as fronteiras; e a administração era conduzida, em geral, sem nenhuma referência aos desejos populares. ${ }^{35}$

\footnotetext{
32 RENAN, 1997, p. 13. Tradução nossa: "O esquecimento, e eu diria mesmo o erro histórico, é um fator essencial para a criação de uma nação, e, sendo assim, o progresso dos estudos históricos é frequentemente para a nacionalidade um perigo".

${ }_{34}^{3}$ RENAN, 1991, p. 33. Tradução nos sa: "As nações não são algo eterno. Elas começaram, elas vão acabar".

34 MOREIRA, 1999, p. 312.

${ }^{35}$ ACTON in BALAKRISHNAN, 2000, p. 25.
} 
Mas também o historiador português Alexandre Herculano, na introdução ao romance $O$ bobo, de 1843, mostrava-se consciente de que "A idéia de nação e de pátria não existia para os homens de então [o período medieval] do mesmo modo que existe para nós". ${ }^{36}$

O fato é que a literatura, assim como a crítica literária, ambas dentro do propósito de matriz romântica de valorizar não diretamente o universal, como no classicismo, mas o particular, contribuíram enormemente para a consolidação e legitimação da ideia de nação. Foi o caso do romantismo brasileiro, em larga medida comprometido em constituir ou explicitar nossa identidade nacional, atendendo, desse modo, às demandas ideológicas da independência declarada em 1822. No que a isso se refere, são pertinentes as palavras de Luiz Costa Lima a respeito de Gonçalves de Magalhães, inaugurador das letras românticas no Brasil, poeta que "abre uma linha de pensamento que só tenderá a crescer", válida "tanto para seus contemporâneos, quanto para as gerações sucessivas", isto é, "a afirmação de pátria [que] constituirá a justificação primeira de uma intelligentsia nativa". ${ }^{37}$

E foi o caso também de Portugal, cuja literatura oitocentista caracteriza-se, segundo Eduardo Lourenço, pela evocação do dever cívico, que impelira escritores a pensar a pátria em novos moldes, e a tentar compreender o que era, afinal, ser português. Entre antes de 1825, quando se publica o Camões de Garrett, e o depois, eis a diferença:

Em toda a nossa literatura anterior - mesmo naquela que sob inspiração humanista tematiza o destino pátrio, como é o caso ímpar de Os Lusíadas a determinação literária procede de um horizonte intelectual, abstracto ou humanisticamente "universal". O interlocutor ideal dos autores é a cristandade em geral, a sociedade universalmente concebida, ou, com mais medíocre alcance, a confraria restrita dos letrados (humanistas, ou não). A relação dos autores com a realidade colectiva enquanto simbolizável, era vivida sem autêntica interioridade. "Portugal" não é ainda apreendido como realidade histórica, em sentido próprio, e muito menos mortal, ou

\footnotetext{
${ }^{36}$ HERCULANO, 1967, p. 12.

37 LIMA, 1986, p.202.
} 
susceptível de morte. Quando os autores glosam o seu destino, em termos épicos ou apologéticos (raras vezes em termos críticos), o seu eu pessoal não se encontra por assim dizer envolvido, implicado na evocação. A exegese óbvia que se costuma fazer da relação Camões -Pátria é um espelhismo romântico. É Camões quem pessoaliza a Pátria, não é ela que o "camoniza", que o problematiza. ${ }^{38}$

A figura e a obra de Camões - como vimos páginas antes - cumpriu papel fundamental nesse percurso da literatura portuguesa, que parte do romantismo e atravessa o século XIX, chegando ao XX. E é Camões que constitui um elemento nevrálgico de tensão entre afastamento e aproximação por parte do Brasil para com a ex-metrópole, cerne este de nossa discussão em torno dos textos que Joaquim Nabuco dedicou ao poeta quinhentista.

Vejamos, por agora, a recepção de Camões no oitocentos português e, em seguida, no brasileiro.

\section{1) Camões em Portugal:}

No que se refere ao contexto específico português, é, pois a partir do poema de Almeida Garrett de 1825 que ocorre uma "identificação de Portugal com Camões", esse que é "caso único no quadro da cultura européia". ${ }^{39}$ E continua Lourenço: "Para os portugueses, Camões não será apenas o maior dos seus poetas - era-o já, desde o século XVII, e não apenas para o seu comentador e hagiógrafo, Faria e Sousa -, mas o seu herói nacional" e "símbolo de Portugal", ${ }^{40}$ conversão que acompanha a d'Os Lusíadas em "O Livro, o breviário

\footnotetext{
38 LOURENÇO, 1991, p.81.

${ }^{39}$ LOURENÇO, 1999, p.57.

40 LOURENÇO, 1999, p.57.
} 
do sentimento exaltado da nossa identidade, num momento dramático da nossa História". ${ }^{41}$

Por que "dramático"? Eduardo Lourenço observa como a epopeia camoniana passa a ter um vínculo forte com períodos conturbados para a política de Portugal, observação, aliás, que já era lugar-comum de comentaristas da obra camoniana, sobretudo de entre o século XIX e princípios do XX. ${ }^{42}$ Mas Lourenço destaca o período em que o reino se vê, em 1808 , abandonado pela família real e pela corte e ocupado por forças napoleônicas:

Foi nessa época que o Morgado de Mateus, para lembrar ao mundo culto, cujo centro, mais do que nunca, era Paris, a nossa tragédia e a nossa grandeza, publicou a edição monumental d'Os lusíadas, ilustrada por gravadores e artistas franceses eminentes. Essa edição transcende o mero acontecimento de ordem cultural e marca o primeiro momento significativo de um processo de canonização patriótica e cívica que iria concretizar-se meio século mais tarde num monumento erigido à glória do poeta. [...] Tratase de um gesto simbólico de afirmação de Portugal aos olhos do mundo cultivado no momento em que a vida nacional atravessa uma fase delicada e sofre com o seu eclipse no palco europeu. ${ }^{43}$

Tal gesto simbólico, no entanto, Eduardo Lourenço não o enxerga na medida e no efeito da publicação do Camões, de Garrett, e da tela hoje perdida do companheiro de liberalismo e de estreia romântica, Domingos Sequeira. O pintor, segundo registros,

\footnotetext{
${ }^{41}$ LOURENÇO, 1999, p.57.

${ }^{42}$ Ramal ho Ortigão, em prefácio da edição comemorativa d'Os Lusíadas de 1880, preparada pelo Real Gabinete Português de Leitura do Rio de Janeiro, escrevia: "O nível da energia e da dignidade portuguesa pode determinar-se, como num termómetro, pelo grau em que se desenvolve ou se deprime o aprêço público à obra de Camões. Desde o último quartel do século XVI até o fim do século XVII tiram-se sucessivamente vinte-e-três edições de Os Lusíadas; no século XIX fazem-se cinqüenta-e-duas edições; no século XVIII fazem apenas dez! A aproximação dêstes números é el oqüente. Não se liam Os Lusíadas no século da intolerância e do despotismo, no século em que D. Pedro II, celebrando o tratado de Methwen [sic], fazia de Portugal uma feitoria inglesa, em que $D$. João $V$ transformava o reino inteiro em uma torpe sacristia por cima da qual badalava o carrilhão de Mafra, em que D. José definia o dogma da soberania absoluta e omnisciente do rei, e D. Maria I, beata até à imbecilidade, convertia em institüições nacionais o histerismo devoto e a gulodice fradesca." (ORTIGÃO, 1945, p. 218. vol. 1) Afrânio Peixoto, em Camões e o Brasil, feria a mesma nota, em 1924, citando Teófilo Braga: "Se Camões morreu com a Pátria em 1580, deixou Os Lusíadas, que haviam de ser o estímul o para o renascimento, sessenta anos depois. Sob o jugo espanhol, as numerosas edições revelam como êles foram a fé e a esperança na redenção: em Inocêncio contei 10 edições entre 1580 e 1640. Insiste Teófilo Braga: 'Basta considerar que o es pírito organizador da Revolução de 1640, João Pinto Ribeiro, comentara Os Lusíadas de sua mão e que todos os movimentos nacionais, como os de 1820, 1834 e 1910 foram conseqüência de uma unanimidade afectiva, inspirada pela compreensão d'Os Lusíadas." (PEIXOTO, 1928, p.68-69)

43 LOURENÇO, 1999, p.58.
} 
tematizava o instante no qual o poeta quinhentista recebia a notícia da União Ibérica, por cujo impacto - já em extremas condições de pobreza e doença - vinha a falecer, dizendo que, pelo menos, morria com a pátria; donde o título A morte de Camões. Com o livro e o quadro, nas palavras de Lourenço, "Camões faz a sua entrada no espaço da mitologia literária e da iconografia romântica". ${ }^{44}$ Desse modo, à semelhança do que teria realizado Sequeira, Almeida Garrett (ambos ressentidos de uma revolução liberal frustrada) compreende Camões como "a imagem de Portugal doente, sofredor, de novo acorrentado depois de ter ressurgido miraculosamente sob a forma de Portugal-Liberdade",45 ou ainda: "Para Garrett, afinal, Camões não é tanto o poeta da Pátria como o da sua ausência, quase da sua perda"46 e seu poema revela a tensão entre "a consciência da desgraça nacional" e a certeza do "triunfo da Liberdade". ${ }^{47}$ Muito da força que o poema teve à época e ainda hoje parece dever-se também à identificação do autor com o personagem, este o duplo daquele, que escreveu a obra no exílio, assim como o outro boa parte d'Os Lusíadas. ${ }^{48}$ Mas observa França: "Camões não é o simples pretexto para a exibição de uma dor pessoal: em 1824, tomado como modelo existencial, ele deve garantir um conhecimento moderno da realidade humana". ${ }^{49}$ Vem a calhar, a esse propósito, o ensinamento de Lourenço, nas palavras do qual, "Os românticos não viajam realmente em direção ao passado, antes trazem o passado para o presente". ${ }^{50}$

Com base no ensaio de Lourenço, intitulado "Romantismo, Camões e a saudade", e no capítulo "Camões e a saudade" do livro O romantismo em Portugal, de França, podemos entender que Garrett (sobretudo, ele) e Sequeira amalgamam, em seus respectivos atos artísticos, praticamente simultâneos, Camões, Portugal, liberalismo, romantismo e saudade.

\footnotetext{
44 LOURENÇO, 1999, p.58.

45 LOURENÇO, 1999, p.58-59.

${ }^{46}$ LOURENÇO, 1999, p.59.

47 LOURENÇO, 1999, p.59.

${ }^{48}$ Cf. LOURENÇO, 1999, p.59; FRANÇA, 1999, p.49.

${ }^{49}$ FRANÇA, 1999, p.49.

50 LOURENÇO, 1999, p.59.
} 
Com efeito, assevera José-Augusto França: “A 'saudade' faz parte do mito de Camões; ela ficará ligada ao mito do Romantismo, que tomará Camões como testemunha, se não como padrinho". ${ }^{51}$ Referindo-se ao fato de Garrett ter, em seu poema de 1825, retomado simbólica e textualmente Os Lusíadas-Camões, sendo a obra do poeta oitocentista "o primeiro grande texto português tecido com o poema camoniano", Eduardo Lourenço detecta "um fundamento original a essa recuperação e metamorfose do texto épico, fazendo da palavra Saudade, e do sentimento que ela exprime, a sua verdadeira musa". 52 Por fim, "o próprio Camões é uma encarnação, entre outras, apesar de ser a mais sublime de todas, de um sentimento que está para além dele, e que todos os portugueses partilham, essa inexplicável mistura de sofrimento e de doçura a que chamam saudade". ${ }^{53}$ Tal sentimento, transformado numa doce dor existencial e nacional, segundo Lourenço, dita o ritmo da musicalidade lamentosa, algo desesperada, não obstante seu otimismo libertário, de Camões. Mas haveria nessa obra, para José-Augusto França, um caráter de "poema-suicídio", na medida em que ela "deveria ser (ainda que tal fosse impossível...) o último poema de Garrett - o seu primeiro e último poema romântico, exemplar único num domínio onde mal penetrara", conforme prometera e, de certa forma, cumprira o autor, de modo que este "gostaria de ter dito, ou parece dizer, que morria com a pátria ingrata, [e ainda] diz, sem querer, ou sem dar por isso, coisas bem profundas sobre a situação de uma geração que passava o limiar de uma nova época da história nacional. Eis porque o poema teve o maior êxito". ${ }^{54}$ Paralelamente, teríamos o fracasso da instauração romântica na pintura portuguesa, a que se proporia a tela de Domingos Sequeira ${ }^{55}$ - fracasso da Revolução de 1820 e de todas as revoluções e esperanças dos que, durante o século XIX,

\footnotetext{
${ }^{51}$ FRANÇA, 1999, p.51.

52 LOURENÇO, 1999, p.59.

53 LOURENÇO, 1999, p.59.

54 FRANÇA, 1999, p.50.

${ }^{55}$ Cf. FRANÇA, 1999, p.51.
} 
como Almeida Garrett e alguns membros da Geração de 70, fomentavam para remediar o estado decadente e as condições de atraso vividos por Portugal.

Sem dúvida, Almeida Garrett foi o maior nome da literatura portuguesa da primeira metade do século XIX, ligado à recepção da vida e obra camonianas, sobretudo no que se refere a uma recepção criativa. ${ }^{56}$ Seu Camões tornado herói cívico, romântico avant-la-lettre, sua epopeia convertida em bíblia da nacionalidade portuguesa, é imagem que perdura ao longo do oitocentos e ainda hoje parece sobreviver no imaginário popular lusitano (obra de grande responsabilidade salazarista). Devemos acrescentar a essas considerações relativas ao autor quinhentista na primeira metade do século XIX o processo de homerização romântica desse mesmo poeta, analisada por Carlos Manuel Ferreira da Cunha em seção de sua tese intitulada A construção do discurso da história literária na literatura portuguesa do século XIX. Na verdade, desde o século XVI e principalmente no decorrer do XVII, Os Lusíadas ensejaram comentários, pautados na poética clássica que se normatizava pela imitatio, nos quais se comparava Camões a Homero e Virgilio, ora aquele considerado equiparável a estes, ora mesmo superior, a depender do entusiasmo do comentarista. O critério que, via de regra, justificava o situar a epopeia camoniana perante os poemas homéricos e a Eneida é o de que "se trata dum poema perfeito, porque obedece perfeitamente aos preceitos do gênero". ${ }^{7}$ Em suma, porque Camões o compusera, respeitando o modelo épico dos poetas grego e latino. ${ }^{58}$ Todavia, no oitocentos, temos uma "afirmação da prioridade do critério genético na apreciação das obras literárias em detrimento do poética clássica". 59 Isso resultava,

\footnotetext{
${ }^{56}$ Em sua obra estritamente crítica, Bosquejo da poesia e da língua portuguesa (1826), Almeida Garrett informava que, devido à celebridade do poeta d'Os Lusíadas, nele não se detinha para "tratar de menos conhecidos nomes". (GARRETT, 1963, p.493. vol.1)

${ }^{57}$ PIRES, 1982, p.13.

${ }^{58}$ Gonçalves Pires esclarece que os comentaristas camonianos dos séculos XVI e XVII conjugavam o critério da imitatio e da aemulatio, pois "alguns críticos [compreendem] que os estreito quadro das normas do género e o princípio da imitação são instrumentos insuficientes para explicar a beleza da epopeia camoniana que lhes aparece, em muitos aspectos como obra original". (PIRES, 1982, p.16)

${ }^{59}$ CUNHA, 2002, p.84.
} 
concomitantemente a uma romantização de poetas como Camões, em nome de seu patriotismo, sua vida desventurada, numa leitura de perspectiva histórica que levava a um F. Bouterweck, em 1805, a considerar que o autor d'Os Lusíadas "quis ser para os portugueses o que Homero foi para os gregos (chama-lhe 'the Portuguese Homer')"; 60 a um Friedrich Schlegel afirmar sobre a epopeia camoniana:

[...] son poème contient en outre tout ce que l'histoire ancienne de sa nation présente de beau, de noble, de grand, de chevaleresque e de touchant, coordonné en un seul tout. Ce poème embrasse toute la poèsie de sa nation. De tous les poèmes heroïques des temps anciens et modernes, il n'en est point qui soit national à un aussi haut degré. Jamais, depuis Homère, poète n'a été honoré et aimé de sa nation autant que Camoëns; de sorte que tout cette nation, déchué de sa gloire immédiatement après lui, a conservé de sentiments patriotiques, se rattache à ce seul poète, qui peut à juste titre nous tenir lieu de beaucoup d'autre, et même d'une littérature tout entière. ${ }^{61}$

Na segunda metade do século XIX, em Portugal, há duas vertentes básicas da imagem de Camões. Uma delas faz a manutenção da heroicização romântica de matriz garrettiana; a outra a refuta, por vezes pela crítica, pela ironia, pela paródia, desmistificando o poeta quinhentista como espécie de anjo-custódio da nacionalidade lusitana. Teófilo Braga, o mais influente nome da camonologia luso-brasileira do período, direciona-se de acordo com a primeira dessas vertentes, sendo de se assinalar a ligação intelectual, observada tanto por Carolina Michaëlis quanto por A. do Prado Coelho, que ele procurou assumir com Almeida Garrett, no que diz respeito às "aspirações nacionais, do levantamento da alma nacional", 62 aspecto em comum que "havia de concorrer para dar a sua acção literária e política [a de

\footnotetext{
${ }^{60}$ CUNHA, 2002, p.85.

${ }^{61}$ SCHLEGEL apud CUNHA, 2002, p.85. Tradução nossa: "seu poema contém, além de tudo, o que a história antiga de sua nação apresenta de belo, de nobre, de grande, de cavaleiresco e de comovente, estruturado em uma unidade. Esse poema abarca toda a poesia de sua nação. Dentre todos os poemas heroicos dos tempos antigos e modernos, não há um que seja nacional em tão elevado nível. Jamais, depois de Homero, algum poeta foi tão honrado e amado pela sua nação quanto Camões; de modo que es sa nação, imediatamente destituída de sua glória, depois dele, mesmo assim conservou sentimentos patrióticos, se liga a esse único poeta, que pode com justiça ser tomado por muitos outros e mesmo por toda uma literatura."

${ }^{62}$ COELHO, 1921, p.12.
} 
ambos os portugueses] a direcção que vieram a tomar". ${ }^{63}$ E Camões, tanto para Garrett quanto para Teófilo, seria essa figura-chave do patriotismo que deve agir na consciência literária e política de Portugal. A outra vertente podemos verificar, a título de exemplos eloquentes, na recepção crítica de Oliveira Martins e Antero de Quental e na obra de Eça de Queirós e Cesário Verde. ${ }^{64}$

Ao apresentar tese em concurso para cadeira na Faculdade de Letras em Lisboa, em 1872, concorrendo com Pinheiro Chagas, Teófilo Braga defendia compreensão acerca da história da literatura portuguesa que, por um lado, confirmava o consenso de que se tratava de uma literatura sem originalidade, ${ }^{65} \mathrm{e}$, por outro, trazia a novidade da concepção rácica para explicar a produção literária nacional. $\mathrm{O}$ trabalho sustentava-se na suposta existência ancestral de uma raça moçárabe, que respondia pela constituição de Portugal como nação com base em fatores naturais e não morais, conforme alguns autores, a exemplo de Alexandre Herculano, Oliveira Martins e Antero de Quental, propunham. Junto ao moçarabismo, Teófilo "relegava a literatura culta (clássica) para um plano secundário e colocava no núcleo do sistema literário a 'literatura popular', de origem medieval, inspirando-se em Garrett”, bem como alçava os textos medievais a patamar "superior à maior parte das obras literárias do patrimônio

\footnotetext{
63 COELHO, 1921, p.13.

64 Infelizmente, não tivemos amplo acesso aos trabalhos desse autor referentes a Camões, triste lacuna desta monografia, que também não se beneficiou da consul ta ao artigo de Hernani Cidade, "Como o meu camonismo se sente apoiado em Joaquim Nabuco". De todo modo, mencionemos brevemente o Visconde de Juromenha, o outro grande nome da camonologia portuguesa oitocentista. Nos trabalhos desse autor, basearam-se o próprio Teófilo, Ramalho Ortigão, Oliveira Martins. Entre os anos de 1860 e 1869, Juromenh a publicou os seis dos sete volumes prometidos da Obras de Camões, com biografia e textos comentados (o último volume jamais viria a público). Sua importância para os estudos camonianos é de tal ordem, que foi convidado para presidir a comissão que organizaria as comemorações do tricentenário de morte do autor d'Os Lusíadas - aliás, o 10 de Junho de 1580 como a data em que Camões falecera foi estabelecida por Juromenha. Embora não aceitasse o honroso posto, alegando idade avançada, doença e necessidade de isolamento, acabou sendo considerado presidente honorário da comissão das comemorações camonianas.

${ }^{65}$ O que, mais uma vez, atesta a influência do pensamento crítico-literário alemão sobre os portugueses, pois, segundo Carlos Manuel Ferreira da Cunha, "a cartografia literária dos irmãos Schlegel e de Madame de Staël estabelecia uma fronteira nítida entre as literaturas orgânicas/nacionais [caso das anglo-germânicas e grega antiga] e as inorgânicas/imitativas [caso das neolatinas e latinas]" (CUNHA, 2002, p.232). Tal concepção determinava a visão historiográfica portuguesa sobre a literatura no próprio país.
} 
nacional, remetidas para o limbo da 'imitação inorgânica"”.66 Quanto a Camões, cronologicamente pertencente ao classicismo, Teófilo aparecia com a solução de que o poeta quinhentista constituía um milagre, em decorrência do qual se convergiam a alma renascentista (culta) e a alma medieval (popular), entendimento que o autor retomará em sua obra mais importante, História da literatura portuguesa: "Camões, cuja característica é a conciliação dos dois espíritos clássico e medieval." ${ }^{\text {67 }}$

Eleito pelo próprio Auguste Comte um dos santos cívicos festejados no oitavo mês do calendário positivista, Camões ensejaria, ao se completarem os trezentos anos de sua morte, oportunidade valiosa para Teófilo Braga - cujo pensamento, em 1880, estava sob os influxos do positivismo - insuflar sentimentos patrióticos no ânimo nacional e também propagandear o republicanismo num país governado por monarquia acusada de incapacidade de resolver as mazelas sócio-políticas seculares de Portugal. O Camões liberal de Garrett tornava-se, então, o Camões republicano de Teófilo, o grande poeta nacional abandonado à miséria, no fim de sua vida, pelo governo insensível às artes e desastrosamente incompetente para com a pátria.

Em oposição a Teófilo Braga dentro dos limites luso-brasileiros, a voz camoniana mais notável é provavelmente a de Oliveira Martins, que, juntamente com Antero de Quental, em termos intelectuais e afetivos, afrontou o futuro primeiro presidente da República portuguesa. Assim como Joaquim Nabuco, por ocasião do terceiro centenário d'Os Lusíadas, Oliveira Martins, então aos 27 anos de idade, publica ensaio sobre Camões que escrevera, no desterro em Santa Eufémia, cidade espanhola, por imperativos profissionais, - informa o autor - sem acesso a biblioteca adequada ou livros senão ao próprio poema épico e à Eneida. $\mathrm{O}$ volume, intitulado Os Lusíadas: ensaio sobre Camões e a sua obra em relação à sociedade portuguesa e ao movimento da Renascença, assim como o de Joaquim Nabuco, seria alvo das

\footnotetext{
${ }^{66}$ CUNHA, 2002, p.232.

${ }^{67}$ BRAGA, 2005, p.273.
} 
críticas severas de Teófilo Braga, em artigo de 1873. O historiador oitocentista, posteriormente insatisfeito com o trabahho, fará editá-lo uma segunda vez, duas décadas depois, com modificações importantes, pois, assume o próprio autor, o texto, em sua primeira versão, estava “inçado de erros, continha puerilidades, carecia de ser refundido para não ser de todo indigno, nem do público, nem, sobretudo, do culto que toda a minha vida tributei a Camões". ${ }^{68}$ E o republicará assim, como gesto sintomático dentro do contexto nacionalmente traumático: no ano seguinte ao Ultimatum inglês de 1890. Esse fato, de ordem cronológica, importa termos em mente para compreendermos melhor os propósitos desse integrante da Geração de 70, cujo círculo de que participa já na época se auto-intitulava Vencidos da Vida.

No ensaio, rebatizado de Camões, Os Lusíadas e a renascença em Portugal, Oliveira Martins transcreve artigo que havia saído no jornal O comércio português de 10 de junho de 1880, onde declara as razões de não se entusiasmar com a apropriação patrioticamente redentora do poeta quinhentista:

Camões escreveu um poema que foi um epitáfio, porque a sociedade que cantou acabou com ele. Os Lusíadas consagram as obras dos heróis. Pensamos nós acaso repetir-lhes as façanhas com o fácil e cómodo endeusamento do poeta?

Perigosa ilusão que pode levar a supor-nos felizes e meritórios! Quando os Lusíadas se leram ao rei, tudo eram festas e esperanças no reino. Preparavase Alcácer Quibir. E todos acreditavam - incluindo o poeta em pessoa - que se ia conquistar Marrocos com a seta que o Papa mandara a D. Sebastião... ${ }^{69}$

Uma década depois das comemorações do tricentenário da morte de Camões, Oliveira Martins vê transplantado para o presente a tragédia do passado: o entusiasmo nacional que antecedera a catástrofe de Alcácer Quibir parecia prefigurar o entusiasmo de 1880 e o trauma

\footnotetext{
${ }^{68}$ MARTINS, 1952, p.7-8.

69 MARTINS, 1952, p.11.
} 
nacional com o Ultimatum inglês de 1890. E, ao fim e ao cabo, Os Lusíadas não seria a bíblia do patriotismo lusitano, conforme apregoavam tantos comentaristas, dentre os quais Teófilo Braga e seus discípulos, mas o epitáfio do heroísmo português ou ainda "o testamento de um futuro não cumprido". ${ }^{70}$ Também em História da civilização ibérica, de 1879, o integrante da Geração de 70 já tomava a epopeia camoniana, embora em termos mais amplos, como "um livro que é o testamento da Espanha" e ainda contestava o ensinamento (teofiliano) de que Camões era um fenômeno à parte em meio à renascença de Portugal:

Camões não é um fenómeno isolado no seio da sociedade portuguesa, porque o seu poema se gerou com essência do pensamento mais íntimo dela, revelado no carácter especial que distingue, no XVI século, os nossos heróis - um Alburque e um Castro de um Cortês e de um Pizarro. ${ }^{71}$

A propósito, Eduardo Lourenço pontua a proximidade das concepções de Oliveira

Martins e de Antero de Quental em torno do quinhentista e sua obra; para esses integrantes da Geração de 70, Os Lusíadas

[...] não pod[e] conferir identidade ou dignidade a um país que a seus olhos simboliza a decadência, decadência quase estrutural, que dura há trezentos anos e não é puramente episódica - provocada de fora, pelos estrangeiros e, de dentro, pelos inimigos da Liberdade - como no tempo de Garrett. Em última instância, Camões e o seu Livro - pelo menos para Antero de Quental - podem ser englobados também eles no processo de decadência, pois o autor dos Sonetos atribui aos feitos que o poema canta uma quota-parte de responsabilidade no drama da nossa decadência. ${ }^{72}$

Está claro que Lourenço tem aí em mente uma das "Causas da decadência da península ibérica nos últimos três séculos", título da célebre conferência que Antero

\footnotetext{
${ }^{70}$ MARTINS, 1952, p.14.

71 MARTINS, [s.d], p.186.

72 LOURENÇO, 1999, p.60-61.
} 
pronunciara em 1871. Se a expansão ultramarina, ao lado do absolutismo e do catolicismo, provocara o estado decadente da nação, o fato de Os Lusíadas celebrá-la seria necessariamente negativo para a obra, destituída, portanto, de sua condição de bỉblia da nacionalidade. Já Oliveira Martins, compreendendo a decadência como algo irremediável, pois decorria da exaustão do organismo nacional, que se comprometera com todas as suas conquistas gloriosas, postulava que a epopeia camoniana, "mesmo na sua época, não era [...] um livro de glória, um livro verdadeiramente solar, mas antes o memorial de um povo em declínio e prometido à morte". 73

Lourenço também comenta a contribuição queirosiana nessa recepção desromantizadora de Camões, destacando a cena final d'O crime do padre Amaro, na qual a presença da estátua do quinhentista, às personagens, "só lhes suscita comentários ásperos ou mesmo cínicos", e "acaba assim, de uma maneira quase burlesca, no mesmo sítio onde o poeta tinha recebido a consagração suprema, numa praça soalheira de Lisboa, vagamente atenta aos longínquos rumores da Comuna, o papel romântico de Camões". ${ }^{74}$ Deve-se acrescer que Eça de Queirós, em carta a Carlos Mayer, tecia a seguinte comparação, muito significativa de sua opinião acerca do quinhentista português: "Camões, o filho da Renascença e das imitações latinas, não tem o espírito épico de João de Barros, que, às vezes, numa página, constrói toda a antiga alma heroica da pátria". ${ }^{75}$ Desse modo, o romancista de $A$ ilustre casa de Ramires rebaixa o tradicionalmente considerado o grande épico português perante João de Barros, mais apto do que o poeta d'Os Lusíadas para reproduzir e incutir o sentimento heroico e patriótico pela história de Portugal.

Outro autor que contribuiu, na segunda metade do século XIX, para a desmistificação do poeta quinhentista como anjo-custódio do patriotismo português é Cesário Verde, cujo

\footnotetext{
73 LOURENÇO, 1999, p.61.

74 LOURENÇO, 1999, p.62.

${ }^{75}$ QUEIRÓS apud MACHADO, 1986, p.66.
} 
célebre "O sentimento dum ocidental" reservaria para Camões um lugar incômodo e nada épico ou heroico na pátria oitocentista. Flavio Garcia Vichinsky, em monografia de mestrado defendida em 2009, interpreta a estrofe do poema de Cesário, 'Mas, num recinto público e vulgar, / Com bancos de namoro e exíguas pimenteiras, / Brônzeo, monumental, de proporções guerreiras, / Um épico de outrora ascende, num pilar!", 76 da seguinte forma:

O poeta faz alusão ao mesmo monumento citado por Eça de Queiroz [ao fim d'O crime do padre Amaro], desvalorizando-o inicialmente quando mostra que aquele local é "vulgar" [...]. Rodeado por "bancos de namoro" mostra que o ambiente é propício para outras atividades, que não a de reflexão sobre o próprio Camões, muito menos a leitura do seu poema. A ornamentação com "exíguas pimenteiras" nos faz lembrar que a pimenta era uma das especiarias trazidas da Índia. Representando as pimenteiras minguadas dessa forma, aos pés de Camões, entendemos que todas as grandezas das conquistas marítimas, simbolizadas pela presença de Camões e do seu épico, também se tornaram exíguas em Portugal. ${ }^{77}$

Passemos a verificar o que se dava, no mesmo período, no Brasil, com relação à imagem de Camões.

\section{2) Camões no Brasil:}

Já soubemos que o chefe dos primeiros românticos, Gonçalves de Magalhães, não nutriu admiração pelo quinhentista português. Mas quanto a certamente o primeiro mais importante poeta do romantismo brasileiro, Gonçalves Dias, Hamilton Elia enxerga no resquício neoclássico de sua poesia reverência à obra camoniana - donde a pergunta: "Seu poema épico Os Timbiras, com que tencionou mostrar 'capacidade de arquitetar e executar uma epopéia nacional brasilíada, inspirada nos fatos e costumes da raça que tanto amou e

\footnotetext{
${ }^{76}$ VERDE, [s.d], p.100.

77 VICHINSKY, 2009, p.97.
} 
exaltou', não apontam, por acaso, ecos de Os Lusíadas?", ${ }^{78}$ não se privando Elia de recordar a similitude do episódio trágico-marítimo que aproxima o autor de "I-juca-pirama" e o de Rimas. ${ }^{79}$ De todo modo, pelo menos em comparação com os poetas anteriores e posteriores, a poesia romântica brasileira em geral parece ter muito pouca ligação com Camões, privilegiando - entre a possibilidade, tipicamente romântica, de poder "sentir a genialidade de Camões" e a postura lusófoba, característica específica de nosso romantismo -, esta última. ${ }^{80}$

Pelo menos dois românticos brasileiros de destaque, Álvares de Azevedo e Casimiro de Abreu, ${ }^{81}$ propuseram-se a compreender o poeta português. O primeiro, criticamente, em Literatura e civilização em Portugal. O segundo, criativamente, em Camões e o jau. Todavia, o propósito textual daquele e os contornos contextuais deste não permitem pensarmos uma plena absorção de Camões à ideia de literatura brasileira e de Brasil.

O ensaio azevediano analisa a literatura portuguesa, à qual por critérios sóciolinguísticos a brasileira pertenceria ("sem língua à parte não há literatura à parte" ${ }^{\natural 2}$ ), detendose em duas épocas entre si antagônicas: o "período heroico", protagonizado por António Ferreira e Luís de Camões, e o "período das trevas", em que "Bocage é rei". ${ }^{83}$ Sabemos que o autor de Lira dos vinte anos professava verdadeiro culto a esse poeta meio neoclássico, meio pré-romântico, identificando-se profundamente com a imagem que constrói de Bocage, que reiteradamente aparece na obra azevediana. ${ }^{84}$ Além disso, Camões é rebaixado perante

\footnotetext{
${ }^{78}$ ELIA, 1973, p.34.

79 ELIA, 1973, p.34.

${ }^{80}$ Cf. TELES, 1976, p.191-192.

${ }^{81}$ Não nos podemos furtar a esta nota. Afirmamos ser Casimiro de Abreu um romântico brasileiro de destaque por mera observação de que o poeta (sem, afinal, o merecer) enquadra-se no cânone do nosso romantismo. É lamentável que a canonização periodológica imponha a manutenção de certos nomes poeticamente inexpressivos das letras nacionais (na falta de algo melhor), a o passo que um Da Costa e Silva, por exemplo, um Cornélio Pena não gozem de igual prestígio em livros sobre literatura do ensino médio.

${ }^{82}$ AZEVEDO, 2000, p.715.

${ }^{83}$ AZEVEDO, 2000, p.737.

${ }^{84}$ Desculpamo-nos por nos citar a nós mesmos, divulgando o artigo "A binomia de duas almas irmanadas: Bocage na obra de Álvares de Azevedo", publicado no número 5 da Revista Crioula, onde noticiamos: "[...] na leitura da opera omnia do romântico brasileiro, deparamo-nos com a presença bocagiana em vários lugares e de formas variadas. Para nos atermos às aparições explícitas, temos: 1) a citação do verso "Cantando a vida
} 
Ferreira, no que diz respeito às respectivas recriações do episódio de Inês de Castro. Sendo assim, o amante de Dinamene não constitui interesse maior por parte do jovem poeta paulista, ao escrever, no início do ano de 1850, seu ensaio. Por outro lado, segundo o poeta de Lira dos vinte anos, Os Lusíadas constituiria um marco na história da literatura e da civilização portuguesas: 'Da epopeia de Camões, perdoe-se-nos o erro, se é que o há em dizê-lo, é que data a inteira separação de literaturas [espanhola e portuguesa], em Portugal o timbre de apurado estudo, e a preferência das falas nacionais". ${ }^{85}$

Seja como for, Os Lusíadas impelem Azevedo a recriminar as ofensas de Byron, seu outro grande ídolo literário, com estas palavras: "Poeta! e esqueceras que essa nação sobre cujo túmulo pisavas tinha por Edda o livro de Luís de Camões, menestrel como o Tasso, guerreiro como Godofredo, amante como Petrarca, vagabundo como Dante, sublime e laureado das palmas da guerra como tinhas de sê-lo?"86 Algo que também merece menção, em Literatura e civilização em Portugal, é o fato de Álvares de Azevedo postular a não-separação entre a produção literária brasileira e a literatura portuguesa - questão que abordaremos mais detidamente no próximo capítulo.

Mais de um lustro depois, Casimiro de Abreu veria encenada pela primeira vez sua curta peça Camões e o jau; mais precisamente a 18 de janeiro de 1856. A obra dramática foi escrita e estreou em Portugal, onde o autor - então aos 17 anos de idade - encontrava-se a estudar Comércio, cumprindo a contragosto uma vontade paterna. O lugar de criação parece-

\footnotetext{
como o cisne a morte", como uma das epígrafes de Lira dos vinte anos; 2) no poema "O Editor", pertencente à segunda parte dessa mesma obra, a menção ao nome do autor de Rimas, 3) assim como na estrofe XXV do primeiro canto de $O$ poema do frade, 4) numa fala de Penseroso, personagem de Macário, e 5) na segunda parte do primeiro artigo sobre Jacques Rolla, de Alfred de Musset; 6) em nota ao quarto artigo desse mesmo estudo, a expressividade 'terna' de certos momentos da poesia bocagiana é comparada à de duas estrofes de Torquato Tasso; 7) o poeta português, no prefácio a $O$ conde Lopo, parece ser refutado como autor de certos poemas 'infames, corrompidos e corruptores' (AZEVEDO, 2000, p.378), tradicionalmente a ele atribuídos e 8) aparece como personagem no poema lírico-dramático "Glória moribunda"; 9) em Noite na taverna, o velho que interrompe a narrativa de Bertram lembra-se de ter bebido com o poeta de Setúbal, e, 10) no estudo ensaístico Literatura e civilização em Portugal, há toda uma seção dedicada a el e." (DRUMOND, 2009, p.2)

${ }^{85}$ AZEVEDO, 2000, p.715.

${ }^{86}$ AZEVEDO, 2000, p.724.
} 
nos dizer muito das motivações que levaram Casimiro de Abreu a escolher tal assunto, suposto episódio da vida de Camões. Já àquela altura produto da heroicização patriótica garrettiana, o tema da peça dificilmente desagradaria à plateia, posto que se tratasse de teatro medíocre ou ruim, como é o caso. De qualquer forma, acreditamos valer a pena deter-nos nessa obra, sem dúvida um dos marcos da presença camoniana na literatura e na cultura oitocentistas brasileiras.

Nessa peça, o que observamos é um processo simultâneo de romantização e abrasileiramento do tema. Casimiro de Abreu amolda algumas falas de seu personagem com base no modelo da dicção que marcou o romantismo brasileiro. Os versos seguintes, pronunciados por Camões, recordam de imediato as canções do exillio de Gonçalves Dias e do próprio Casimiro, com seus “Ai, que saudades!", seus sabiás e tutti quanti:

Que saudades que eu tinha desta terra,

Destas veigas risonhas, destas fontes,

Destas flores mimosas, destes ares!

Nunca naquelas regiões tristonhas

O riso do prazer me veio aos lábios.

[...]

Lá não trinava o rouxinol gorjeios

$\mathrm{Na}$ balseira virente em noite bela,

Quando a lua prateada se retrata

Sobre as águas do lago sossegado;

Lá não ouvia a gemebunda rola

Gemer saudosa... que entristece tanto! $!^{87}$

Assim, o patriotismo do personagem parece também expressar o patriotismo do autor, afirmado e fundamentado no prólogo da peça, em que o poeta fluminense argumenta sobre sua saudade do Brasil, com base na identificação - muito significativa - com o índio:

Não há que valha a terra natal. Tirai o índio do seu ninho e apresentai-o d'improviso em Paris: será por um momento fascinado diante dessas ruas,

\footnotetext{
${ }^{87}$ ABREU, [s.d.], p.31.
} 
dessas praças, desses templos, desses mármores; mas depois falam-lhe ao coração as lembranças da pátria, e trocará, de bom grado, ruas, praças, templos, mármores, pelos campos da sua terra, pela sua choupana na encosta do monte, pelos murmúrios da floresta, pelo correr dos seus rios. Arrancai a planta dos climas tropicais e plantai-a na Europa: ela tentará reverdecer, mas cedo pende e murcha, porque the falta o ar natal, o ar que the dá vida e vigor. Como o índio, prefiro a Portugal e ao mundo inteiro o meu Brasil, rico, majestoso, poético, sublime. Como a planta dos trópicos, os climas da Europa enfezam-me a existência, que sinto fugir no meio dos tormentos da saudade. ${ }^{88}$

Casimiro de Abreu, pertencente ao cânone do romantismo nacional, autor de canções de tom ufanista, enxergou na biografia e na poesia de Camões espelho onde refletir a própria imagem, de poeta saudoso da terra. A peça é tão simples na arquitetura dramática e superficial na constituição psicológica dos personagens quanto, via de regra, se apresentará a poesia de Casimiro. ${ }^{89}$ Seja como for, o caso casimiriano parece consistir numa exceção entre os autores brasileiros.

Com o esgotamento do romantismo brasileiro, parecem ter sucedido mudanças importantes nesse quesito. Segundo Gilberto Mendonça Teles, Olavo Bilac será o "maior camonista entre os parnasianos", além de "o restaurador literário do culto a Camões", 90 do que é testemunho seu soneto "No tronco de Goa", que integra o volume A tarde:

Camões sofre, na infâmia da clausura,

Pária sem honra, náufrago sem nome;

E rala, na saudade que o consome,

$\mathrm{O}$ pobre peito contra a pedra dura.

O seu gênio ilumina a abjeta lura...

Mas a vida das carnes se the some:

\footnotetext{
${ }^{88}$ ABREU, [s.d.], p.25-26.

${ }^{89}$ Ou seja, Camões e o jau, a primeira obra de Casimiro de Abreu que o público conheceu, fixou o patamar psicológico dos textos posteriores do poeta carioca, assim sintetizados no ensinamento de Antonio Candido, segundo o qual o autor de Primaveras privilegiou "os temas relativamente mais comuns da psicologia humana e os aspectos mais familiares da paisagem, tratando a uns e outros como menor amplitude". (CANDIDO, 2000, p.179. vol 2)

${ }^{90}$ TELES, 1976, p.144; cf. tb. p.205.
} 
Míngua de pão, e, outra mais negra fome,

Indigência de beijos e ventura.

Do próprio fel, dos íntimos venenos,

Faz a glória da pátria e a luz da raça;

E chora, na ignomínia. Mas, ao menos,

Possui, na mesquinhez da terra crassa

E na vergonha de homens tão pequenos,

O orgulho de ser grande na desgraça. ${ }^{91}$

De fato, o crítico goiano noticia o significativo aumento de interesse na vida e na obra do poeta português, dentre intelectuais e literatos brasileiros, aumento impulsionado pelos dois tricentenários festejados na segunda metade do século XIX: o de publicação d'Os Lusíadas e o de morte de seu autor. Teles chega mesmo a situar nesse período, de 1872 a 1882, o nascimento da camonologia no Brasil e ver como seu fundador Joaquim Nabuco. ${ }^{92}$

$\mathrm{Na}$ obra de Machado de Assis, as referências, os vestígios camonianos são numerosos, ${ }^{93}$ alguns supostamente mais discretos, como em $O$ Almada. ${ }^{94}$ Tu, só tu, puro amor resulta de encomenda do Real Gabinete Português de Leitura do Rio de Janeiro para marcar o terceiro centenário de morte de Luís Vaz de Camões. Publicou-se a peça em 1881, mesmo ano das Memórias póstumas de Brás Cubas, o romance que marca a guinada do percurso literário machadiano.

A comédia tem como centro da ação a relação amorosa proibida entre Camões e D. Catarina de Ataíde, a que se associam os sentimentos de Caminha, tão invejoso do engenho do outro poeta quanto ciumento da correspondência que este encontra no amor da dama do palácio. Vingativamente Caminha acaba por noticiar ao pai de Catarina esse relacionamento, que rende ao protagonista o desterro. $\mathrm{Na}$ visão de D. Antônio, tal punição "restituiu honra a

\footnotetext{
${ }^{91}$ BILAC, 1997, p.315.

${ }^{92}$ Cf. TELES, 1976, p.144-145.

${ }^{93}$ Cf. ELIA, 1973, 39-41.

${ }^{94}$ Cf. TELES, 1976, p.150; 203 e261.
} 
um vassalo, e a paz a um ancião", 95 sem temor de poder, com isso, matar a filha de desgosto, pois "Amores fáceis de curar são esses que aí brotam no meio de galanteios e versos. Versos curam tudo. Só não curam a honra os versos; mas para a honra dá Deus um rei austero, e um pai inflexível..." ${ }^{96}$ Suas palavras se confirmarão logo a seguir, justificando a denominação de comédia, quando o protagonista encerra a peça, já na perspectiva de superação do afastamento de sua amada:

E não choro, não; não choro... não quero... (Forcejando por ser alegre). Vedes? até rio! Vou-me para bem longe. Considerando bem, Ásia é melhor; lá rematou a audácia lusitana o seu edifício, lá irei escutar o rumor dos passos do nosso Vasco. E este sonho, esta quimera, esta coisa que me flameja cá dentro, quem sabe se... Vede lá, ao longe, na imensidade desses mares, nunca dantes navegados, uma figura rútila, que se debruça dos balcões da aurora, coroada de palmas indianas? É a nossa glória, é a nossa glória que alonga os olhos, como a pedir o seu esposo ocidental. E nenhum lhe vai dar o ósculo que a fecunde; nenhum filho desta terra, nenhum que empunhe a tuba da imortalidade, para dizê-la aos quatro ventos do céu... Nenhum... (Vai amortecendo a voz). Nenhum... (Pausa, fita D. Manoel, como se acordasse, e dá de ombros). Uma grande quimera, senhor D. Manoel. Vamos ao nosso desterro. ${ }^{97}$

De fato, os versos vão curar tudo, versos que se sugere serem da epopeia, que clama por ser escrita, numa comparação bastante conveniente: Camões não esposará D. Catarina de Ataíde, mas, como "fillho desta terra", Portugal, será o "esposo ocidental" da "nossa glória". $\mathrm{Na}$ verdade, em termos psicológicos, não há um salto brusco: primeiro, explica Machado de Assis, em sua nota: "Busquei, sim, haver-me de maneira que o poeta fosse contemporâneo de seus amores, não the dando feições épicas, e, por assim dizer, póstumas", ${ }^{98}$ ou seja, não romantizando o personagem como tanto tinha feito o romantismo; segundo, o protagonista, em certa passagem, diz, cheio de mistérios, haver em sua fronte "alguma coisa mais do que

\footnotetext{
95 ASSIS, 1938, p.303.

${ }_{96}$ ASSIS, 1938, p.303-304.

97 ASSIS, 1938, p.308.

${ }^{98}$ ASSIS, 1938, p.264.
} 
simples versos de desenfado", para a qual the inspiraria um "sonho... Às vezes cuido cá dentro mais do que a minha vida e o meu século... Sonhos... sonhos!"99 e, ao longo da peça, sente-se atraído pela África e pela Ásia: “[...] sinto umas tonteiras africanas. Pois que me fecham a porta dos amores, abrirei eu mesmo as da guerra. Irei lá pelejar, ou não sei se morrer... África, disse eu? Pode ser que Ásia também, ou Ásia só; o que me der na imaginação". ${ }^{100}$ O final de Tu, só tu, puro amor é feliz, como ensinam os cômicos versos de Álvares de Azevedo, em "Namoro a cavalo": "Se ela quisesse eu acabava a história / Como toda a Comédia - em casamento..."101 Na peça machadiana, o casamento se dá com a poesia, o único (“tu só") amor puro que se mantém constante no coração do poeta, que, pela superação de força épica, ${ }^{102}$ vislumbra escrever uma epopeia, inalcançável ao engenho de outros poetas portugueses da época. Assim, a resposta é não à pergunta de Camões, já ciente do decreto de seu desterro: "Venceu então o Caminha? Talvez os versos dele fiquem assim melhores. Se nos vai dar uma nova Eneida, o Caminha? Pode ser, tudo pode ser..."103 Ao vencedor, Os Lusíadas.

Também em comemoração ao tricentenário camoniano de 1880, mas à parte do que organizava o Real Gabinete Português de Leitura do Rio de Janeiro, Miguel Lemos publicou sobre o poeta quinhentista. O autor encontrava-se, então, na França, onde se aprofundava no positivismo de Auguste Comte, chegando a manter contato pessoalmente ou por correspondência com Pierre Lafitte, discípulo direto do filósofo de Montpellier, para já em

\footnotetext{
${ }^{99}$ ASSIS, 1938, p.279.

${ }^{100}$ ASSIS, 1938, p.307.

${ }^{101}$ AZEVEDO, 2000, p.242.

102 Confesso que o lastro dessa leitura deve-se ao ensaio de António Quadros, "Da 'paideia' grega à 'paideia' cristã-europeia e portuguesa", no qual o autor contradiz o caráter trágico atribuído a eventos da história portuguesa (como a batalha de Alcácer Quibir) e a obras da literatura portuguesa (como Castro, de António Ferreira). Quadro enxerga nesses episódios históricos e nesses textos literários uma superação épica, expressão de uma "resistência a o trágico". O sebastianismo, a coroação de Inês e a eternização do amor de Pedro na peça de Ferreira esvaziariam qualquer conteúdo trágico, afirmando-se, sobretudo, pelo espírito épico. (cf. QUADROS, 1989, p. 27-41) Nesse sentido, talvez fosse interessante pensar não propriamente em comédia como classificação para a obra machadiana em questão, mas em 'drama épico'.

103 ASSIS, 1938, p.305.
} 
1881 retornar ao Brasil, onde tomaria a frente, ao lado de Teixeira Mendes, do positivismo no Rio de Janeiro.

O fato de o ensaio ter sido escrito originalmente em francês é significativo, dentro dos propósitos mesmos de divulgação da corrente positivista, especialmente no que se refere à segunda fase do pensamento comtiano, com base no qual Lemos compreende a história de Portugal, na primeira parte do volume, a biografia de Camões, na segunda, e sua poesia, na terceira e última parte. É explícito o caráter doutrinário do texto, que, escrito no idioma então de maior circulação cultural e prestígio e, ademais, em que se pensou o positivismo, situava o autor d'Os Lusíadas no panteão dos santos cívicos a serem cultuados pela Humanidade. Em outras palavras, Miguel Lemos partia do princípio - encerrado na frase de Comte citada como epígrafe da conclusão do ensaio, "Não se deve ver na história uma massa de exemplos, mas deve-se nela procurar uma série de preparações" - de que a importância de comemorar o tricentenário camoniano não se limitava ao mundo lusófono, mas ao mundo todo, pois o homem e o poeta Camões e Portugal teriam participado, de maneira especial, no progresso rumo ao equilîbrio entre razão e emoção e à superioridade do amor pela Humanidade.

$\mathrm{Na}$ seção inicial de "Antécédents historiques", o positivista ortodoxo brasileiro combate as razões políticas para o desinteresse pela história de Portugal e por Camões no mundo não-lusófono, sendo, todavia, otimista com relação à mudança desse quadro:

Mais à mesure que la notion d'occidentalité, systematisée par le Positivisme, rendra plus familière la connaissance du concours historique que présente l'ensemble de l'Occident, Camoëns sera de plus em plus apprécié, car on saisira mieux la part de son pays dans ce développement commun. ${ }^{104}$

104 LEMOS, 1880, p.6. Tradução nossa: "Mas à medida que a noção de ocidentalidade, sistematizada pelo Positivismo, torna mais familiar o conhecimento do concurso histórico que apresenta o conjunto do Ocidente, Camões será cada vez mais apreciado, uma vez que se saberá melhor a contribuição de seu país no desenvolvimento comum". 
Podemos apreender a dimensão da valorização positivista de Camões e da história de Portugal na existência de busto em gesso do poeta no Templo da Humanidade no Rio de Janeiro e, conforme destaca Lemos na segunda parte do ensaio, no fato de o próprio Auguste Comte ter dedicado um dos dias de seu calendário histórico a um dos heróis portugueses, Albuquerque. Em suma, falar de Camões e de Portugal na época em que viveu o poeta, e especialmente em francês, seria conscientizar os leitores acerca de todo um processo histórico em conformidade com a concepção positivista. Compreender e apreciar devidamente a vida e obra camoniana, para Miguel Lemos, não prescinde do conhecimento do contexto em que viveu e escreveu o quinhentista português. A concepção estética do positivista brasileiro, portanto, vincula-se à história e também a uma visão totalizadora.

No ensaio, Lemos elogia a iniciativa dos portugueses ao realizar as comemorações do tricentenário da morte de Camões, redimindo assim "le crime de l'avoir laissé mourir dans la misère", 105 mas também dando mostras de "vigueur nationale", 106 uma vez que "une population qui sait ainsi remonter dans le passé pour acclamer sés grands hommes et rappeler sés traditions oubliées n'est pas morte: elle peut encore espérer une longue vie et retrouver de nouvelles destinées". 107

No que se refere especialmente a Os Lusíadas, essa obra acumularia duas restrições de público, sobretudo na época do positivista brasileiro: a dos não luso-brasileiros, pelo caráter "éminemment nationale"108 e, pela conformidade com "des modèles de convention

\footnotetext{
105 LEMOS, 1880, p.153. Tradução nossa: "o crime de o haver deixado morrer na miséria".

106 LEMOS, 1880, p.153. Tradução nossa: "vigor nacional".

107 LEMOS, 1880, p.153. Tradução nossa: "uma população que sabe assim retomar o passado para acla mar seus grandes homens e evocar suas tradições esquecidas não está morta: ela pode ainda esperar uma longa vida e encontrar novos destinos".

108 LEMOS, 1880, p.258. Tradução nossa: "eminentemente nacional”.
} 
littéraire", ${ }^{109}$ a do vulgo, ao qual a obra seria "peu accessible". ${ }^{110}$ Observa-se, portanto, que o líder positivista ortodoxo brasileiro distingue entre caráter popular e caráter nacional ou nacionalista de uma obra, sendo que, no caso d'Os Lusíadas, ratifica o autor carioca o julgamento de F. Schlegel, "De tous les poèmes héroïques des temps anciens et modernes, il n'en est point qui soit national à un aussi haut dégré". 111

Também há de se considerar, entre o último quartel do século XIX e as primeiras décadas do XX, na opinião de Gilberto Mendonça Teles, o "maior estudioso de Camões entre nós":"112 Afrânio Peixoto.

Júlio Afrânio Peixoto é o estudioso da obra de Camões que, de fato, melhor representa a camonologia brasileira na passagem do século XIX para o XX. Por iniciativa sua, o Brasil financiou a fundação da Cadeira de Estudos Camonianos na Universidade de Lisboa, em 1924 - por ocasião do quarto centenário do que se convencionou ser o ano de nascimento do quinhentista português. Mendonça Teles ressalta o papel de Peixoto ao lado de Nabuco na consolidação de Camões como autor definitivamente de interesse brasileiro:

Assim, quer em 1880, com o terceiro centenário da morte, quer em 1924, com o quarto centenário do nascimento, o culto de Camões - graças, sobretudo, repetimos, a homens como Joaquim Nabuco e Afrânio Peixoto ganhou foros oficiais, chegando em 1972, na comemoração do quarto centenário de Os Lusíadas, às maiores honras já prestadas a um escritor em língua portuguesa. ${ }^{113}$

$\mathrm{Na}$ verdade, Afrânio Peixoto retomou bastante do que se vinha afirmando acerca do autor d'Os Lusíadas no século XIX. Em seu livro Camões e o Brasil, de 1928, reiterou a

\footnotetext{
109 LEMOS, 1880, p.258. Tradução nossa: "model os de convenção literária".

110 LEMOS, 1880, p.258. Tradução nossa: "pouco acessível".

111 LEMOS, 1880, p.193. Tradução nossa: "De todos os poemas heroicos dos tempos antigos e modernos, não há outro que seja nacional a um grau tão elevado".

112 TELES, 1976, p.145.

113 TELES, 1976, p.146.
} 
notória síntese schlegeliana, ao escrever que Camões "é toda uma literatura, um passado, um futuro, um idioma, duas pátrias", ${ }^{114}$ assim como trecho famoso do discurso de Nabuco de 1880: "Dos prodígios que fềz Portugal no Mundo, dois maiores fễz: Camões e o Brasil." 115 Peixoto ainda professou opinião entusiasta típica dos apologistas do poeta português tanto do século XIX quanto de centúrias anteriores, nestes termos: "um tal vate, profeta, génio e herói", 116 retomando Os Lusíadas como "uma bíblia, o livro por excelência do nosso patriotismo, onde podemos ir buscar sempre, em tôdas as crises de desalento, nova energia para novos cometimentos". 117

$\mathrm{Na}$ conferência "Camões e o Brasil", Afrânio Peixoto realizara, em termos mais sumários, o que viriam a fazer, cinco décadas depois, Gilberto Mendonça Teles e Hamilton Elia - isto é - um rastreamento da presença do quinhentista português na literatura e na crítica brasileiras. No ensaio "Camões épico", ratificando a ligação entre Portugal e o Brasil, Peixoto ensinará:

A literatura universal tem em Camões e nos Lusíadas um genial poeta, como Homero, Vergílio, Dante, Tasso ou Ariosto, que cantou o poema moderno, só êle, igual aos outros, e mais novo que os outros, o poema que os resume a todos e a todos excede, num canto vasto e alto... Portugal, o Brasil - seu prolongamento no tempo e no espaço, - nós, os lusíadas, nós temos no Poema a fé de ofício de um povo, nossos pergaminhos, os brasões de nossa raça, nossa história, nossa fé, nossa esperança, e Camões é um dêsses gênios-heróis, representativos de uma civilização, como que o seu grandioso símbolo na Memória do Tempo. ${ }^{118}$

\footnotetext{
114 PEIXOTO, 1928, p.72.

115 PEIXOTO, 1928, p.85.

116 PEIXOTO, 1928, p.54.

117 PEIXOTO, 1928, p.76-77.

118 PEIXOTO, 1947, p.56-57.
} 


\section{3) Recolha conclusiva:}

Nesse panorama luso-brasileiro, constituído por amostra - com efeito, bastante restrita - é que Joaquim Nabuco pensará vida e obra de Camões. E pelo que pudemos averiguar, a recepção oitocentista do poeta d'Os Lusíadas, como um todo cronológico e geográfico, é marcada pelo denominador comum da questão nacional. Se, de acordo com Eduardo Lourenço, os irmãos Schlegel, Ludwig Tieck, Chateaubriand identificaram-se com o patriotismo exaltado, sem deixar de ser crítico, expresso n'Os Lusíadas, é o que se verifica em autores portugueses como Almeida Garrett e Teófilo Braga, aquele convertendo o poeta quinhentista em voz do liberalismo, este em bandeira antimonárquica da causa republicana, e tanto um quanto o outro Camões a representação do mais elevado valor identitário português.

O que se sucede, pois, no período, é uma canonização geral de Camões como poeta da literatura portuguesa e da literatura universal. Canonização seja no sentido mais estritamente literário, seja num sentido que beira à devoção religiosa da filosofia positivista, que converteu o poeta quinhentista em santo cívico: Teófilo Braga e Miguel Lemos estão nessa plataforma. Por outro lado, a compreensão d'Os Lusíadas como a bíblia da nacionalidade lusitana, capaz de alçar o tricentenário de 10 de Junho de 1880 a comemoração a partir da qual, segundo Teófilo Braga, "tira[mos] da maior tradição do nosso passado histórico o estímulo para um renascimento", 119 não foi opinião unânime. Oliveira Martins e Antero de Quental apontavam na obra-prima camoniana o valor negativo da decadência portuguesa.

A identificação transpirenaica com o vate patriota também atingiria os românticos brasileiros, nos quais se costuma diagnosticar sentimentos lusófobos. O caso de Camões e o jau, de Casimiro de Abreu, revela como foi possível conjugar a afirmação da independência

${ }^{119}$ BRAGA in CABRAL, 1973, p.238-239. 
do Brasil e da especificidade da cultura e paisagem brasileiras e a adoção do maior nome da literatura da ex-metrópole como porta-voz de todos os patriotismos. À identificação GarrettCamões, dentro da clave do romantismo e do liberalismo, se sucede a identificação CasimiroCamões, dentro da clave do romantismo, mas com forte coloração brasileira. Está claro que tais fatos respondem ao contexto sócio-político europeu e ocidental em que se vai consolidando o fenômeno tipicamente moderno da nação, capaz de cooptar mentes românticas, sequiosas de alguma justificativa existencial particular e coletiva, e mentes que embarcaram nos ideários da segunda metade do oitocentos e princípios do novecentos.

Álvares de Azevedo e Casimiro de Abreu diferenciam-se, todavia, no tocante à recepção de Camões. A despeito do caráter distinto dos dois textos aqui selecionados - um ensaio crítico e uma peça teatral -, Azevedo não abrasileira o quinhentista português, como o faz Casimiro, mas defende a não-separação das literaturas de aquém e além-mar, questão que exploraremos no próximo capítulo. Seja como for, para o poeta de Lira dos vinte anos o vate d'Os Lusíadas nem constituiria um modelo supremo (haja vista António Ferreira superá-lo na reconstrução ficcional do episódio de Inês de Castro), nem objeto de maior interesse, identificando-se mais proximamente com Bocage.

Já Machado de Assis e Miguel Lemos, contemporâneos e compatriotas de Joaquim Nabuco, constroem, em seus respectivos textos aqui discutidos, um Camões que está para além dos nacionalismos, sendo, acima de tudo, universal. Tu, só tu, puro amor conduz um personagem destinado a escrever uma obra maior, que suplantará o amor por Catarina e os versos amorosos, num desfecho ele mesmo épico que propõe a arte como o "puro amor único", definitivo, do quinhentista português. Lemos, líder do positivismo no Brasil, aplica, em seu ensaio escrito em francês sobre Camões, a concepção de que as nações e o patriotismo consistem em etapas que prefiguram o momento histórico da universalidade. De qualquer 
modo, o autor d'Os Lusíadas, bem como outras grandes personalidades da história, deveriam ser homenageadas e cultuadas como santos cívicos, por terem promovido o avanço da Humanidade.

Quanto a Afrânio Peixoto, podemos dizer que ele reforça a ligação cultural entre Brasil e Portugal em nome de Camões, retomando todo o ensinamento consagrado acerca do poeta quinhentista no século XIX. De fato, o camonólogo baiano reverencia textos de Teófilo Braga, Miguel Lemos, Joaquim Nabuco, Storck, Schlegel... Sua iniciativa de angariar fundos para se fundar cadeira de estudos camonianos em universidade portuguesa é significativa de um empenho no sentido de estreitar o Atlântico, aproximando as duas margens d'aquém e d'além-mar.

Importa frisar que a camonologia oitocentista luso-brasileira deve muito aos comentários e às pesquisas de autores estrangeiros, dívida que se verifica na recorrência de citações em trabalhos de Oliveira Martins, Teófilo Braga, Miguel Lemos e mesmo Joaquim Nabuco. Carlos Manuel Ferreira da Cunha chega a destacar a importância de um diálogo teuto-português e até franco-anglo-português na Umwertung der Camoens'schen Werte que o romantismo em Portugal propôs vitoriosamente: “[...] o Camões romântico e nacional do Morgado de Mateus é um legado da filologia alemã, dos românticos alemães e dos primeiros historiadores da literatura portuguesa, F. Bouterwek, Sismondi e F. Denis." ${ }^{20}$ No caso alemão, quatro nomes se destacam: Friedrich Schlegel, Alexander von Humboldt, Wilhelm Storck e Carolina Michaëlis de Vasconcelos. Do primeiro foi bastante citada a compreensão de que o autor d'Os Lusíadas valeria por toda uma literatura; o segundo, famoso naturalista, por reconhecer no poeta português um exímio pintor em versos da natureza e da paisagem oceânica; a contribuição de Storck reside na primorosa tradução de toda a obra camoniana,

${ }^{120}$ CUNHA, 2002, p.84. 
além de estudos relativos à biografia e à poesia do autor quinhentista; por fim, Michälis, principalmente pelos avanços no âmbito ecdótico para a fixação da lírica de Camões. Cumpre distinguir claramente a relação desses quatro ilustres alemães com a camonologia lusobrasileira oitocentista e novecentista.

A verdade é que Friedrich Schlegel e Alexander von Humboldt tiveram papel maior na comprovação ou endosso de Camões como poeta de valor universal, ${ }^{121}$ isso aos olhos dos próprios portugueses e brasileiros. O prestígio internacional desses homens, um respeitado filósofo, crítico literário e escritor, o outro naturalista de renome, atestava o que o anseio lusófono requisitava, sob a baixa auto-estima de países periféricos como o Portugal e o Brasil da época. Já Wilhelm Storck e Carolina Michaëlis de Vasconcelos foram dois verdadeiros camonistas. Pois, mais do que ratificar o reconhecimento pela Europa culta e industrializada do grande quinhentista português, contribuíram inestimavelmente para o progresso da camonologia oitocentista, reavaliando o que até então havia sido feito para a construção biográfica, a compreensão crítica e a definição ecdótica de Camões.

Não podemos deixar de nos referir à recepção francesa do quinhentista português, também - como seria de outro modo, dada a enorme influência cultural da França no mundo luso-brasileiro do século XIX? - presença marcante nos trabalhos de autores d'aquém e d'além-mar. Sendo o iluminista Voltaire um dos primeiros franceses a comentar, com ampla projeção, a poesia camoniana, é, entretanto, Edgard Quinet autor que, em Génie des religions, atentará para a necessidade de “étudier les rapports des cultes d'Orient avec ceux de la

\footnotetext{
${ }^{121}$ No prólogo à edição d'Os Lusiadas de 1613, Pedro Mariz noticia o duvidoso caso de um fidalgo alemão - por ele não nomeado - "que pediu ao seu correspondente em Lisboa informações sobre o túmulo de Camões, falando da 'veneração que tão insigne hom e merecia". (EHRHARDT, 1972, p.55) Já no século XIX, o Visconde de Juromenha, em sua "Advertencia preliminar" à edição das Obras de Luís de Camões, de 1861, "para que se não julgue que é opinião de um enthusiasta que sabe comtudo reprimir o seu enthusiasmo á vista da verdade, quando é necessario", cita "o juizo insuspeito de um estrangeiro, o sabio traductor das obras do mesmo Camões, D. Lamberto Gil”. (JUROMENHA, 1861, p.VI)
} 
Grèce", ${ }^{122}$ uma vez que "De leur union naîtra l'âge moderne, dont les Lusiades sont l'expression, poëme qui ouvre des temps modernes, en scellant l'alliance de l'Orient et de l'Occident". ${ }^{123}$ Ao lado de Quinet, Sismonde de Sismondi e Ferdinand Denis - acima mencionados - chegaram a tratar, divulgando em idioma de tanto prestígio na época, como o francês, não apenas a vida e a obra camonianas, como a literatura portuguesa em geral. São esses três outros que colaboraram para o reconhecimento universal de Camões no oitocentos e, em especial, no universo luso-brasileiro.

Mas que Camões Joaquim Nabuco delineou em seus textos de 1872, 1880 e 1908-09? Como o autor pernambucano lidou com esse contexto de tão acentuada abordagem nacionalista do objeto literário e do poeta quinhentista em especial? É o que procuraremos responder nos dois próximos capítulos desta monografia.

122 QUINET apud FRÈCHES, 1972, p.52. Tradução nossa: "estudar as relações dos cultos orientais com aqueles da Grécia antiga".

${ }^{123}$ QUINET apud FRÈCHES, 1972, p.52. Tradução nossa: "Da união destes nasceu a idade moderna, da qual Os Lusíadas é a expressão, poema que abre os tempos modernos, selando a aliança do Oriente e do Ocidente". 


\section{CAPÍTULO 2:}

UM CAMÕES LUSO-BRASILEIRO:

A RECEPÇÃO NABUCOANA EM 1872 E 1880 


\section{1) Camões e Os Lusíadas:}

\subsection{1) Considerações preliminares:}

Camões e Os Lusíadas, livro que ainda não teve segunda edição, publicado em 1872, vem encontrando, ao longo dos tempos, duas recepções básicas e antagônicas, o que verificamos inclusive com relação ao próprio autor. Luís Viana Filho, consagrado biógrafo de Joaquim Nabuco, assim contextualiza a intenção de escrever o ensaio de homenagem ao tricentenário da epopeia camoniana: o filho de senador do império, frustrado o projeto de candidatura a deputado, "como não tinha nada para fazer, gastou o tempo num ensaio sôbre os Lusíadas, [...] quando ainda uma vez, faminto de celebridade e de pressa, se viu de braços cruzados diante do tempo, que voava". ${ }^{24}$ Bem outra é a consideração de Antônio Carneiro Leão; em comentário prévio a conferência originalmente pronunciada em 1949, esse também imortal da ABL, pensando tanto no livro de 1872 quanto nas conferências de 1908-09, asseverou: "Camões foi assim farol e porto de sua existência fecunda, iluminou-lhe o caminho das letras, do início ao fim da vida", ${ }^{125}$ sendo que "Nabuco teve, entre as paixões mais altas de seu espírito e de sua sensibilidade, duas dominantes: a abolição do braço escravo e a veneração imperecedora do génio de Camões". ${ }^{126}$ Essa segunda paixão teria tornado o autor de Um estadista do império

[...] o aedo imortal do idioma português, o artista da forma, o prosador delicioso e inconfundível. Mas foi a fascinação pela beleza poética do grande vate, pela sonoridade da língua dos Lusíadas [sic], da criação singular

\footnotetext{
124 VIANA FILHO, 1973, p.44.

125 LEÃO, 1953, p.5.

${ }^{126}$ LEÃO, 1953, p.5.
} 
desse monumento de amor e de civismo, que norteara a sua sensibilidade, desde os primeiros dias de seu labor de artista. ${ }^{127}$

E Gilberto Mendonça Teles, como vimos no capítulo anterior, chega a atribuir ao Camões $e$ Os Lusíadas o título de marco inicial da camonologia no Brasil. ${ }^{128}$

Aquando da publicação do ensaio do jovem autor (ele contava 23 anos de idade), a se levar em conta a menção destrutiva de José de Alencar, expressa no contexto da polêmica que travaria com Nabuco três anos depois, o livro foi recebido com ululante indiferença pelo público brasileiro. ${ }^{129}$ Em Portugal, porém, Teófilo Braga, que então se esforçava por se firmar como autoridade no assunto, dedicou em 1873 - a esse e a outros dois ensaios (o de Oliveira Martins e o de Francisco Leoni) publicados no ano anterior - artigo no qual os criticava acerbamente. Segundo o integrante da Geração de 70, o Camões e Os Lusíadas de Joaquim Nabuco, falto de fundamentação histórica e consistência analítica, não teria sido escrito "para satisfazer qualquer necessidade intellectual", mas apenas "para festejar um terceiro centenario". ${ }^{130}$ Também recrimina a desatualização com relação às pesquisas camonianas então mais recentes, para concluir nestes termos sua apreciação da obra do autor pernambucano: "O que constitue, em summa, todo o livro? Estylo guidado, cheio de imagens poeticas do ardente lyrismo brazileiro; é um livro feito por quem estava mais apto para as odes amorosas do que para critica da historia."131

Em Minha formação, autobiografia intelectual e política publicada em 1900, Joaquim Nabuco acata, com muita elegância, as críticas de Teófilo:

\footnotetext{
127 LEÃO, 1953, p.5-6.

128 Cf. TELES, 1976, p.144-145.

129 Alencar refere-se ao ensaio de Nabuco como "fóssil estudo sôbre Camões" (ALENCAR in COUTINHO, 1965, p.94) e alfineta: "O Sr. Nabuco, tão môço ainda, já conta em sua vida, nada menos de dous suicídios literários", (ALENCAR in COUTINHO, 1965, p.116) referindo-se, naturalmente, ao ensaio de 1872 e ao livro de poemas em francês Amour et Dieu.

${ }^{130}$ BRAGA in MACEDO, 1880, p.143.

131 BRAGA in MACEDO, 1880, p.147.
} 
Em 1872, o que me ocupa o espírito é o centenário de Os Lusíadas; estou imprimindo um livro sobre Camões, e a quem trabalha em um livro, apesar do seu nenhum valor literário, como o mostrou Teófilo Braga, não sobra muita atenção ou interesse para dar ao que acontece em redor de si [...]. ${ }^{132}$

De qualquer forma, os autores açoriano e pernambucano, àquela altura de Minha formação, já contavam com certa afetividade e respeito mútuos, comprovados no convite remetido ao segundo, 20 anos antes, para proferir o discurso das comemorações do tricentenário de morte de Camões, evento organizado pelo Real Gabinete Português de Leitura do Rio de Janeiro, do qual Teófilo Braga era presidente. Este, a propósito, dirá sobre o discurso de Nabuco:

[...] é de uma alevantada eloquencia, e por elle se vê que o orador comprehendeu profundamente $\mathrm{o}$ sentido da festa, terminando com affirmações gloriosissimas para o futuro de Portugal; o genio poetico allia-se n'este trabalho á capacidade scientifica, e em todo esse discurso, que arrebatou uma assembléa de tres mil pessoas, é notavel a calorosa sympathia com que é revivificada a tradição portugueza de que o Brazil tira o seu impulso historico. ${ }^{133}$

Importa dizer que o argumento maior que justificava o convite emitido pelo Gabinete para Joaquim Nabuco ser o orador oficial das comemorações camonianas no Rio de Janeiro era justamente o fato de o então deputado ter publicado o ensaio em homenagem ao tricentenário anterior. É o que informava Ramalho Ortigão, primeiro-secretário da instituição lusobrasileira, em resposta aos ataques de representantes da comunidade portuguesa no Brasil, melindrados com o convite a um brasileiro. Palavras de Ortigão:

\footnotetext{
132 NABUCO, 1981, p.42.

133 BRAGA, 1891, p.293.
} 
A parte principalissima distribuida na festa do centenario ao illustrado Sr. Dr. Joaquim Aurelio Nabuco de Araujo não é a que lhe conferiu nem o nosso respeito pelos seus talentos, que é grande, nem a nossa estimação pela sua pessoa, que não é menor; é a que lhe pertence exclusivamente como o unico escriptor da lingua portugueza que ha oito annos teve a gloria de escrever $[\ldots] .{ }^{134}$

e segue excerto do ensaio nabucoano em que o autor diz de seu entusiasmo em homenagear o poeta português.

Conquanto parecesse acatar as críticas de Teófilo a seu Camões e Os Lusíadas, Joaquim Nabuco, na conferência "The place of Camoens in literature", pronunciada em maio de 1908, irá esclarecer aos estudantes da universidade de Yale:

When I had read the Lusiads for the first time, I at once wrote a book to tell of my wonder, offering for it the only apology that a tribute of love is always acceptable to a poet. I do not repent of having recorded in print that early impression, which has developed into years of faithful admiration and has kept company with my mind throughout life. Still I always intended to renew to Camoens on my decline the vow of my youth, and it is quite an unexpected fortune for me to be allowed to do it before a great American University. ${ }^{135}$

Tal afirmação da validade do ensaio de juventude vai se confirmando inclusive consoante concepção que desqualifica a crítica literária, exposta na conferência seguinte, "Camoens, the lyric poet": "Willing and reasoned admiration is never such a perfect tribute as the

134 ORTIGÃO in MAGALHÃES, 1880, p.16-17.

${ }^{135}$ NABUCO (a), 1924, p.1. Tradução: “Depois de ler, pela primeira vez, os Lusiadas não demorei em externar o meu deslumbramento em um pequeno volume, trabal ho de mocidade para o qual não offereci outra desculpa senão a de que todo tributo de amor deve ser aceitavel a um poeta. Não me arrependo de ter assim registrado minha primeira impressão, que cresceu sempre em annos de culto fiel, e acompanhou o meu espirito através da vida inteira. Sempre, porem, tive a intenção de renovar a Camões, antes de morrer, a homenagem que lhe prestei na mocidade. Feliz é o ensejo que se me apresenta agora de desempenhar-me deste voto perante uma grande Universidade americana." (NABUCO, 1940, p.1) 
unconscious one, that which does not know where it begins and where it ends."136 A nosso ver, Nabuco aí parece sobrepor, nas entrelinhas, a valorização de seu velho livro Camões e Os Lusíadas, fruto de "verdadeiras impressões pessoaes", ${ }^{137}$ no qual Teófilo Braga não havia visto "nenhum valor literário", atacando sutilmente o que o próprio positivista republicano da Geração de 70 portuguesa publicava e publicara sobre Camões, exemplo de admiração willing e reasoned.

Por outro lado, Nabuco teria negado a Camões e Os Lusíadas o título de livro de estreia, em favor de $O$ abolicionismo, de 1883. Em suma, se houve e há duplicidade no conjunto da recepção ao ensaio de 1872, uns the enaltecendo o valor, outros o criticando, o próprio Nabuco demonstrou ser ambíguo em relação a sua obra de juventude, postura que se compromete ainda mais, uma vez que, ao contrário de Oliveira Martins, jamais o reformularia. $^{138}$

Com Camões e Os Lusíadas, o autor pernambucano procedia a um costume que se consolidava no século XIX ou, mais precisamente, na era dos impérios. Dentro desse período, explica Hobsbawm, os centenários tornaram-se datas comemorativas importantes para o Ocidente. Na lição do historiador:

Os centenários foram inventados ao fim do século XIX. Em algum momento entre o centésimo aniversário da Revolução Americana (1876) e o da Revolução Francesa (1889) - ambos comemorados com as exposições internacionais da praxe - os cidadãos instruídos do mundo ocidental tomaram consciência do fato de que aquele mundo, nascido entre a

\footnotetext{
${ }^{136}$ NABUCO (b), 1924, p.22. Tradução: “A a dmiração voluntaria e arrazoada nunca é tributo tão perfeito qua nto a admiração inconsciente, aquella que ignora onde principia e onde acaba." (NABUCO, 1940, p.56) 137 NABUCO, 1872, p.5.

${ }^{138}$ Acresce, como dado muito curioso e sintomático, que Angela Alonso, na cronologia apensa ao volume que escreveu dedicado à vida de Nabuco, noticia para o ano de 1872 a publicação do romance Ressurreição, de Machado de Assis, mas não o Camões e Os Lusíadas do próprio biografado. (ALONSO, 2007, p.356)
} 
Declaração de Independência, a construção da primeira ponte de ferro do mundo e a tomada da Bastilha, estava completando cem anos. ${ }^{139}$

Mas (sabemo-lo) não apenas episódios históricos teriam seus centenários. Homens, obras artísticas também. Em 1870, por exemplo, em plena efervescência da atmosfera bélica entre a França e a Prússia, o compositor Richard Wagner lembrava o povo alemão, em ensaio, de que então se completavam cem anos de nascimento de Ludwig van Beethoven. No seu próprio ensaio de 1872, quando também Oliveira Martins e Francisco Leoni na Península Ibérica, homenageavam em volume os três séculos da edição princeps d'Os Lusíadas, Nabuco contextualizava bem seus propósitos:

Em 1859, em 1864 e em 1865, a Allemanha, a Inglaterra e a Italia celebrárão com festas nacionaes os centenarios de Schiller, de Shakespeare e de Dante.

Publicando hoje estas notas, não faço mais do que fizeram os homens de coração d'esses três paizes, quando, deixando os campos, vinham ás cidades cobrir de flores as estatuas dos poetas. ${ }^{140}$

Parte desses eventos comemorativos do século XIX refletia uma atitude relativamente nova, que era o culto ao gênio, expresso significativamente em obras literárias, como o Tasso de Goethe e, nos limites luso-brasileiros, as que fizeram de Camões personagem literário de contornos psicológicos admiráveis ou mesmo heroicos, como o poema de Garrett e a pequena peça de Casimiro de Abreu. Recordemos, a esse propósito, uma das lições de Eduardo Lourenço, trazida a esta monografia no capítulo anterior, de que, com o romantismo, os grandes homens do passado passam a ocupar "o lugar vago pela ausência do Deus vivo" e

\footnotetext{
139 HOBSBAWM, 2003, p.29.

140 NABUCO, 1872, p.16-17.
} 
“destinos como o de Camões, de Tasso ou de Cervantes adaptam-se perfeitamente aos critérios e às exigências do novo olhar literário". ${ }^{141}$

Mas a questão no tocante ao ensaio de Nabuco não concerne apenas ao culto ao gênio, mas de como este, celebrado nos centenários, corresponde a anseios da vaidade nacional ou patriótica ou ainda nacionalista. O fato de esse tipo de comemoração ter-se intensificado dentro da era dos impérios faz-nos compreender bem o porquê do seu cariz recorrentemente nacionalista. Pois terá sido ao acaso ou mera coincidência a escolha dos republicanos brasileiros pelo ano em que se distanciavam 100 anos da Conjuração Mineira, e, além do mais, eleito o mártir Tiradentes herói da nação sob o novo governo? ${ }^{142}$ Em Portugal, o tricentenário d'Os Lusíadas não teve o apelo que o da morte de Camões, oito anos depois, alcançará, após o qual se festejaram os do Marquês de Pombal, em 1882; do infante D. Henrique, em 1894; o de Santo António, em 1895; o da viagem de Vasco da Gama às Índias, em 1898 e do descobrimento do Brasil, em 1900, para nos atermos ao século XIX. Todas essas celebrações tinham por objetivo, mais ou menos explícito ou consciente, exaltar a própria nação, que era berço de homens e feitos de tão relevante vulto.

Perante o que fica dito aqui, é curioso que Joaquim Nabuco tenha homenageado um poeta português, em tal contexto acima esboçado. Mas nos refiramos, previamente, ao que o professor Roberto Acízelo de Souza denomina de "o culto brasileiro da literatura portuguesa", fenômeno (digamos) que, obviamente, só viria a ocorrer a partir da independência do Brasil, quando certa corrente da crítica e historiografia literária do País postula a continuidade de uma ligação cultural estreita entre ex-metrópole e ex-colônia, sobretudo no tange ao pertencimento da produção de autores brasileiros à literatura portuguesa, bem como de a literatura portuguesa ser patrimônio igualmente dos brasileiros. Esse é, na verdade, o ponto

\footnotetext{
${ }^{141}$ LOURENÇO, 1999, p.55.

${ }^{142}$ Sobre o assunto cf. capítulo 3 do incontornável trabalho de José Murilo de Carval ho, A formação das almas: o imaginário da república no Brasil.
} 
nevrálgico da discussão que Joaquim Nabuco desenvolve na introdução ao Camões $e$ Os Lusíadas. Desse modo, aprofundaremos,a seção 2.1.3, o que aqui por ora sinalizamos.

Façamos agora um apanhado geral acerca desse livro de 1872.

\subsection{2) O que propõe o ensaio:}

Seja, porém, a sorte de Portugal feliz ou adversa, esteja elle destinado á cruéis revezes ou á um brilhante futuro, a fama do poeta não será alterada. Gloria incomparavel a do homem, que como Luiz de Camões, é sempre através dos seculos a expressão viva dos triumphos, das esperanças, da morte e da resurreição de seu paiz! ${ }^{143}$

São essas as linhas que encerram Camões e Os Lusíadas. As palavras acima citadas quase bastam por si sós para filiarmos esse livro do jovem Joaquim Nabuco à tradição crítica, de matriz romântica, contra a qual, um século depois, Jorge de Sena lutará: “Camões não é o pastelão patriótico-clássico que durante anos tem sido" e, quanto a Os Lusíadas, "os portugueses podem realmente admirá-lo, [...] sem que, para tal, seja necessário apelar para sentimentos nacionais ou para a simpatia dos amigos de Portugal". ${ }^{144}$ Seja como for, o ensaísta pernambucano considerava Camões um poeta "eminentemente nacional"145 e Os Lusíadas "o livro da patria", escrito para que "a alma da nação respirasse em seus versos, e que fosse elle em todos tempos o deposito das esperanças, das tradições, da gloria de Portugal". 146

\footnotetext{
143 NABUCO, 1872, p.286.

144 SENA, 1970, p.III.

145 NABUCO, 1872, p.30.

146 NABUCO, 1872, p.106.
} 
De fato, o ensaio de Nabuco integra aquele processo iniciado em fins do século XVIII de romantização interpretativa de Camões - processo, aliás, de mãos dadas com o de homerização do quinhentista português. Segundo Carlos Manuel de Ferreira Cunha, a exegese camoniana romântica ter-se-ia baseado no que Vico e F. Wolf propuseram acerca da poesia homérica. ${ }^{147}$ Nessa clave hermenêutica, A. von Humboldt intitulará o autor d'Os Lusíadas de o "Homero das línguas vivas"148 e F. Bouterwek, de "the Portuguese Homer","149 Friedrich Schlegel afirmará que “Jamais, depuis Homère, poète n'a été honoré et aimé de sa nation autant que Camoëns", ${ }^{150}$ até que um Almeida Garrett se refira ao compatriota do século XVI como "o nosso Homero portuguez". 151

Joaquim Nabuco, insistentemente, ao longo do ensaio, aproxima Os Lusíadas à Ilíada e, por conseguinte, Camões a Homero. $\mathrm{Na}$ verdade, os fundamentos interpretativos explanados pelo autor pernambucano parecem ser todos voltados para esse fim. Os Lusíadas seriam uma epopeia individual, conforme a tipologia proposta no livro de 1872, mas sua condição de ser o mais nacional dos poemas épicos fá-lo-ia possuir algo das epopeias nacionais (ou primitivas), como a Ilíada. Se esta narra duas ações conjuntas (a ira de Aquiles e a Guerra de Troia), Os Lusíadas também (a viagem de Gama e a História de Portugal), sendo que na obra camoniana a fusão de uma com a outra ação se daria mais perfeitamente do que na obra homérica. Segundo Nabuco, "As mais bellas pinturas dos Lusiadas são desenhadas com as cores de Homero com um raio do Olympo". ${ }^{152}$ A respeito da passagem em que Vênus salva os portugueses de iminente naufrágio, acredita o ensaísta:

\footnotetext{
${ }^{147}$ Cf. CUNHA, 2002, p.83.

${ }^{148}$ Cf. CUNHA, 2002, p.83.

149 Cf. CUHNHA, 2002, p.85. Tradução nossa: "o Homero português".

${ }^{150}$ SCHLEGEL apud CUNHA, 2002, p.85. Tradução nossa: "Jamais, depois de Homero, algum poeta foi honrado e ama do pela sua nação como Camões".

${ }^{151}$ Cf. CUNHA, 2002, p.86.

152 NABUCO, 1872, p.153.
} 
Não se póde dizer ao certo como procedeu Homero compondo a Iliada; não se sabe se ha em todas essas fabulas poeticas um fundo de verdade, e menos poder-se-hia reconstruir a historia dos tempos heroicos tomando, por conjectura a parte dos mythos que se julgasse verosimil; mas o que nos parece é que Homero divinisou heróes populares, e explicou de um modo maravilhoso acontecimentos historicos, que antes delle já a imaginação do povo havia tornado legendarios. Se assim foi, Camões procedeu do mesmo modo ao crear essa fresca e deliciosa ficção. ${ }^{153}$

E quando Nabuco vai recriminar o poeta homenageado por ter erotizado em demasia a figura ideal de Vênus, é porque ele "merece n’este ponto as censuras de Platão á Homero". ${ }^{154}$ Os exemplos poder-se-iam multiplicar. Esses são suficientes para comprovar como Joaquim Nabuco dançou conforme a música da recepção camoniana oitocentista europeia e portuguesa, em tal quesito, em Camões e Os Lusíadas.

Seu ensaio também não se desviou da via biográfica de mão dupla pela qual grande parte da crítica do século XIX transitou: buscava-se compreender a obra, conhecendo-se o poeta; conhecia-se o poeta, compreendendo sua obra. A estrutura de Camões e Os Lusíadas dividido em três livros: o primeiro dedicado a "Camões antes d'Os Lusíadas", o segundo ao período de composição da epopeia e o terceiro à "Velhice e morte de Camões" - parece-nos sugerir a plena adoção dessa concepção. Ao decidir não construir a biografia completa primeiro para depois analisar o poema épico, mas sim inserir a análise entre a mocidade e a velhice e morte de Camões, é como se Os Lusíadas se fundisse perfeitamente no período da vida em que o poeta escreveu sua obra-prima.

Ainda sobre a construção biográfica realizada no ensaio de 1872, o autor baseou-se, sobretudo, em Faria e Sousa, a quem em nota reverencia como o "mais authorisado dos biographos de Camões", ${ }^{155}$ e no Visconde de Juromenha, o primeiro grande camonólogo do século XIX. Costume da ensaística da época, Nabuco não sistematiza as referências a esses (e

\footnotetext{
153 NABUCO, 1872, p.181.

154 NABUCO, 1872, p.188.

155 NABUCO, 1872, p.280.
} 
outros) autores, tampouco problematiza as informações que forneceram, como por altura do início da década de 1870 Wilhelm Storck começava a fazer. Ao que tudo indica, Joaquim Nabuco desconhecia ainda os trabalhos do camonista alemão, que apontaria a irresponsabilidade de uma série de dados confirmados por ambos os biógrafos portugueses (Faria e Sousa e Juromenha). De qualquer forma, o autor pernambucano assume ter tido apego a prováveis lendas enxertadas na vida de documentação tão lacunar como é a de Camões, isso em nome da mais eficiente popularização do poeta. Já na introdução lemos:

Não toucarei assim nas roupas de marmore em que a posteridade envolveu a estatua do poeta, nem tratarei de quebrar o prestigio seductor de suas desgraças. A tradição é a historia. Seria uma profanação mentir a ambas, só para seguir os passados de uma opinião que quer destruir todos os cultos da humanidade, decompor as lendas, mostrar os lados pequenos dos grandes homens. Como se um mytho não fosse a resultante de um longo trabalho de idealisação e como se a humanidade não tivesse querido, formando-os, crear modelos inalteraveis para progresso de todos! ${ }^{156}$

Seria, portanto, mais conveniente acreditar-se que o vate lusitano tivera a sua Laura (identificada em D. Catarina), pois tal amor comoveria e interessaria a amplo espectro de leitores. Ademais, Nabuco crê poder apenas um amor verdadeiro inspirar os poemas amorosos tais quais os atribuídos à autoria camoniana.

Gênio precoce, que, antes de escrever Os Lusíadas, já contaria com obra superior à dos contemporâneos portugueses, e gênio desafortunado, mas de admirável correção moral (sem auto-compaixão, nutrindo amor desinteressado tanto por Catarina quanto pela Pátria); um poeta, enfim, sempre movido pelos mais nobres sentimentos. Eis o retrato, sem dúvida romantizado, que Joaquim Nabuco ofereceu de Camões nesse ensaio. A tese de que o gênio implicaria uma vida tormentosa, perante a conclusão de que o quinhentista português teve a

${ }^{156}$ NABUCO, 1872, p.9-10. 
vida mais desgraçada do que a de Tasso e Milton, conduz à inferência seguinte: se tanto sofreu é porque maior era sua genialidade. E, com efeito, Nabuco esforça-se por comprovar, no que concerne seja à vida, seja à obra (ambas intimamente associadas, na verdade), a superioridade de Camões, só não acima de Homero.

António Carneiro Leão chama a atenção para a falta, no ensaio, de sustentação argumentativa em torno do porquê Os Lusíadas superariam a Eneida e a Divina comédia. ${ }^{157}$ A nosso ver, a argumentação nabucoana aí é muito clara: o ensaísta pernambucano se aferra ao critério do enquadramento no gênero épico, em certa medida aquele mesmo critério clássico de avaliação de uma epopeia; obedece ou desobedece aos modelos de Homero e Virgílio? No caso de Camões e Os Lusíadas, o épico camoniano teria superado o virgiliano e o dantesco por ser mais afim aos sentimentos nacionais, num otimismo heroico. O mais problemático no ensaio diz respeito à originalidade conjugada com a subserviência ao código poético quinhentista, que, paradoxalmente, teria feito Os Lusíadas uma obra antiquada. Nessa lógica meio ilógica, Camões abdicou da universalidade de um Shakespeare, de um Dante, de um Homero, em benefício da glória da Pátria cantada na epopeia. A verdade é que Joaquim Nabuco opera analiticamente - nem sempre com felicidade - com algumas tensões nas quais Os Lusíadas se situaria: entre originalidade e imitação; modernidade e antiguidade; nacionalidade e universalidade.

Feito esse comentário geral ao livro, procedamos à análise da introdução, texto que mais nos interessa neste percurso de nossa monografia.

${ }^{157}$ Cf. LEÃO, 1953, p.19-21. 


\subsection{3) “A literatura portuguesa, que é nossa!":}

A introdução a Camões e Os Lusíadas é, posto que pouco conhecido, documento de grande interesse para pensarmos o diálogo dos brasileiros com a literatura portuguesa, em período não muito posterior ao 7 de Setembro de 1822. Se, como ensinam Antonio Candido e toda uma tradição historiográfica, "o Romantismo no Brasil foi episódio do grande processo de tomada de consciência nacional, constituindo um aspecto do movimento de independência", ${ }^{158}$ vozes se fizeram ouvir, algumas plenamente classificáveis como românticas, que não ostentavam nenhum "interesse pela autonomia literária". ${ }^{159} \mathrm{O}$ professor Roberto Acízelo de Souza introduziu primorosamente a questão, ao tratar de dois nomes (o cônego Januário da Cunha Barbosa e o general José Inácio de Abreu e Lima), representantes cada um de um dos lados de uma verdadeira polêmica em torno da separação ou não da literatura brasileira frente à portuguesa:

Nossa historiografia literária oitocentista é usualmente apresentada como uma unânime profissão de fé nacionalista, que só teria olhos para a grandiosidade do Brasil, cuja natureza privilegiada e história heróica seriam promessas e garantias de uma literatura igualmente rica e destinada à glória futura. No entanto, é possível verificar que esse não é o único tom do pensamento sobre nossa cultura literária formulado na época, havendo vozes que se opuseram a essa posição de entusiasmo e ufanismo, acentuando, ao contrário, nossos problemas e limites e, ao mesmo tempo, sinalizando para concepções em que a idéia de nacionalidade não se absolutizasse a ponto de apagar as dimensões universais da literatura. ${ }^{160}$

\footnotetext{
${ }^{158}$ CANDIDO, 2000, p.281. vol.1

${ }^{159}$ CANDIDO, 2000, p.281. vol.1

${ }^{160}$ SOUZA, 2007, p.41.
} 
Surpreende como Joaquim Nabuco, em sua introdução ao ensaio de 1872, assume lugar por entre essas vozes que desafinaram o coro ufanista, dentro de um percurso que Acízelo de Souza esclarece principiar na década de 1840 e avançar até, pelo menos, Machado de Assis, com o célebre artigo "Instinto de nacionalidade", publicado em 1873. Frente ao que Afrânio Coutinho ${ }^{161}$ batizara, divulgara e analisara como a "polêmica da Minerva fluminense", travada entre 1840 e 1860, e mesmo o ensaio de Álvares de Azevedo, Literatura e civilização em Portugal, escrito em 1850, o texto machadiano, ao propugnar que "os vínculos de uma literatura com determinada nação antes se revelam por certo 'sentimento íntimo' do que pela presença ostensiva e grosseira de um mero 'instinto de nacionalidade", comprovaria que não se trata de "um rasgo de clarividência isolada [por parte do romancista de $A$ mão e a luva], tendo na verdade [...] raízes que vão muito longe". ${ }^{162}$ Roberto Acízelo de Souza, ao analisar a historiografia literária do século XIX brasileira, detecta, portanto, duas correntes relativas à literatura brasileira e portuguesa: uma separatista e outra unionista, sendo que a primeira passaria a predominar a partir de meados do oitocentos, com os trabalhos de Antônio Henriques Leal, Sívio Romero, e José Veríssimo, ${ }^{163}$ ao passo que a segunda sobreviveria até os dias atuais no interesse dos brasileiros pela literatura portuguesa, visto que esta

[...] nunca foi considerada propriamente estrangeira em nosso país, conforme compreensão que se firmou já no século XIX. Assim, quer pelo sentimento de familiaridade que despertava nos brasileiros, decorrente da circunstância de servir-se da mesma língua corrente no Brasil, quer pelo suposto caráter derivado da literatura brasileira em relação à portuguesa, foi ela amada e

\footnotetext{
${ }^{161}$ É digno de nota que o próprio crítico baiano não se absteve, ainda em meados do século XX, em intervir, de certa forma, na questão de nossa autonomia literária. Em "Conceito de literatura brasileira", contestando o antinacionalismo de Antonio Candido, acusadamente expresso em Formação da literatura brasileira, defende Coutinho: "A literatura brasileira não começa no momento arcádico-romântico. Vem de antes, partiu do instante em que o primeiro homem europeu aqui pôs o pé, aqui se instalou, iniciando uma nova realidade histórica, [...] germinando uma nova literatura." (COUTINHO, [s.d.], p.40)

${ }^{162}$ SOUZA, 2007, p.53.

${ }^{163}$ Cf. SOUZA, 2007, p.95.
} 
estudada por brasileiros, pelo menos ao mesmo tempo em que se tornava objeto de estudo dos historiadores literários portugueses, se não mesmo antes disso. ${ }^{164}$

Veremos que a introdução a Camões e Os Lusíadas merece constar na história dessa questão político-identitária de nosso oitocentos, em articulação comparativa tanto com o período romântico quanto com integrantes do que podemos convencionar denominar de Geração de 70 brasileira. Esta, para os propósitos deste capítulo, será aqui representada por Machado de Assis, Silvio Romero e José Veríssimo.

Na parte introdutória de Camões e Os Lusíadas, após destacar, levado seja pela franqueza, seja pela falsa modéstia, seja pelo que havia em si de romântico, que seu ensaio era resultado principalmente de "impressões pessoaes" provocadas pela epopeia camoniana, o autor discorre sobre as fortes emoções decorrentes da leitura e releitura d'Os Lusíadas. Em seguida, assinala a necessidade de os brasileiros passarem a ler esse livro "pouco lido e pouco conhecido"165 no Brasil, mais seduzido, segundo o jovem autor, por obras efềmeras da literatura francesa que, deixando de falar "ao espirito", apenas falariam "ao sistema nervoso, à sensibilidade doentia das mulheres histericas e aos homens ciosos". ${ }^{166}$ Essas obras efêmeras, está claro, pertenceriam ao romantismo francês, assaz influente e popular no meio cultural brasileiro em todo o século XIX. Desse modo, se a linguagem nabucoana, em Camões e Os Lusíadas, ainda não se desapegou de todo das orientações retóricas românticas, ${ }^{167}$ há algo na

\footnotetext{
164 SOUZA, 2007, p.77-78.

165 NABUCO, 1872, p.5.

${ }^{166}$ NABUCO, 1872, p.7-8.

167 Leiamos o trecho seguinte, extraído da introdução de Camões e Os Lusíadas: "Quando se o [um grande poema] lê á primeira, vez [sic] parece que se comtempla um céo estrellado em noite de verão; sente-se espalhado por todo elle um ar de magestade e de grandeza, que nos faz dizer - ahi está o génio. Temos a vertigem do infinito." (NABUCO, 1872, p.6) É patente a filiação do texto a certa retórica romântica que encontramos, por exemplo em ensaio de Álvares de Azevedo ("Bocage - aquela alma era negra como as cavernas escuras onde o mar rebenta com um murmúrio lúgubre." (AZEVEDO, 2000, p.738)) ou em versos de um Castro Alves. O que corrobora a crítica de Teófilo Braga ao ensaio de Nabuco, com seu estilo "cheio de
} 
concepção crítica do autor recifense que rejeita o romantismo, em nome de uma literatura mais elevada, posto que mais antiga, caso d'Os Lusíadas. Aqui, portanto, o classicismo surge como oposição à literatura romântica desvalorizada por Joaquim Nabuco.

Mas, decerto, o ponto nevrálgico da introdução de Camões e Os Lusídas é o manifesto de uma concepção de literatura portuguesa e de literatura brasileira que não comunga do que se tornaria mais aceite entre críticos e historiadores do Brasil àquela altura. Joaquim Nabuco esclarece: "Escolhendo Os Lusiadas para objeto de meus estudos, acredito que tomei um assunto nacional. Os Lusiadas são a obra-prima da literatura portuguesa, que é nossa"168 afirmação a que sucede menção a trabalhos nos quais havia o "intuito de dar-nos uma literatura própria". ${ }^{169}$ Entretanto, assevera o autor categoricamente: "ela ainda não existe". ${ }^{170}$ É que, lemos páginas adiante, "não está no poder de um homem, nem de um grupo, mudar a natureza das coisas e que as literaturas formam-se lentamente, como a língua, a religião e a sociedade". ${ }^{171}$

50 anos separavam a publicação de Camões e Os Lusíadas do 7 de Setembro; nesse ínterim, o romantismo brasileiro, em termos gerais, tinha procurado afirmar nossa autonomia identitária e literária frente a Portugal e à Europa, recorrendo, de modo significativo, ao que poderia ser o tema mais genuinamente nacional: o índio. Nas palavras de Bernardo Ricupero:

Se o problema principal para os brasileiros depois da independência é se pensarem como brasileiros e não mais como portugueses, portuguesesamericanos ou mesmo pernambucanos, paulistas, rio-grandenses, etc, o índio ou, ao menos, a idéia que se decide fazer dele, lhes oferece para isso múltiplas possibilidades. Em primeiro lugar, encontravam-se aqui antes dos

imagens poeticas do ardente lyrismo brazileiro". Mas devemos observar que a altissonância condoreira marca a retórica de muitos discursos do Joaquim Nabuco deputado.

168 NABUCO, 1872, p.10.

169 NABUCO, 1872, p.10.

170 NABUCO, 1872, p.10.

171 NABUCO, 1872, p.14. 
portugueses, sendo possível, portanto, considerá-los os primeiros brasileiros. $^{172}$

Afirmando haver dois caminhos pelos quais os escritores brasileiros procuravam chegar à autenticidade ou originalidade da literatura brasileira - a tematização indianista e a captação da sociedade do País na época -, o ensaísta pernambucano refuta, nesse propósito, a validade do primeiro caminho, argumentando que:

Uma litteratura, inspirada pela vida errante das tribus primitivas, que se servisse amplamente de seu rude vocabulario, que não nos descrevesse senão os seus costumes, seria bem uma litteratura tupy ou guarany, mas não a brazileira. A poesia pôde idealisar o caracter, o coração, as guerras, a civilisação até d'esses ferozes habitantes de nossos sertões; mas a poesia, que se impuzer essa aliás bella missão, será uma poesia phantastica, sem direito a ser nacional. ${ }^{173}$

Nabuco, desse modo, negava que o País fosse, em sua essência identitária, indígena, pois, a formação do Brasil, resultado de um processo de colonização, contara justamente com o extermínio e expulsão dos povos aborígenes. Sendo assim, no que havia de território civilizado: "Nada ficou sobre o solo attestando a antiga existencia das tribus primitivas $[\ldots]^{\prime \prime} \cdot{ }^{174}$

Descartado o filão indianista, restaria a solução de "expressar o estado da sociedade", ${ }^{175}$ havendo de distinto em relação à Europa (e ao mundo), "em nossa honra [...] a natureza", e "para nossa vergonha [...] a escravidão". ${ }^{176}$ Com efeito, Joaquim Nabuco compreende que o regime escravocrata comprometia profundamente a estrutura social

\footnotetext{
172 RICUPERO, 2004, p.153.

173 NABUCO, 1872,p.11.

174 NABUCO, 1872,p.11.

175 NABUCO, 1872,p.13.

176 NABUCO, 1872,p.13.
} 
brasileira, de modo que "ha sempre nas obras dos escriptores, que querem ser nacionaes, traços, reflexos, signaes d'essa deploravel instituição". ${ }^{177}$ Vale destacar, à guisa de parênteses, que essa concepção esboçada no texto introdutório de Camões e Os Lusíadas, ganhará contornos mais nítidos no "Manifesto da Sociedade Brasileira contra a Escravidão", redigido e publicado em 1880, segundo o qual, conforme noticia Angela Alonso, "a escravidão era o fulcro da herança colonial - 'a chaga ainda aberta da velha colonização Portuguesa'. A abolição [portanto] era indispensável para completar a modernização e autonomia política."178 Mas já em ensaio que prometia ser a primeira publicação em volume do autor, escrito em 1870 e intitulado A escravidão, Joaquim Nabuco diagnosticava: "Toda a nossa existência social é alimentada por esse crime [o regime escravocrata]: crescemos sobre ele, é a base de nossa sociedade. Nossa fortuna donde vem? De nossa produção serva. Suprimi hoje a escravidão, tereis suprimido o país." ${ }^{\prime 17}$

Não há menção a nomes e a obras que exemplificariam essa literatura que se queria nacional, acabando por retratar uma sociedade ainda presa a resquícios dos tempos de colônia. Gonçalves Dias é citado como poeta que escreveu, sim, versos indianistas, mas não teria limitado sua poesia a essa temática, tendo nisso mais razão do que a expectativa de Alexandre Herculano, que gostaria de que as poesias americanas ocupassem espaço maior nos Cantos. Curiosamente, José de Alencar, romancista também marcado por se render ao filão indianista, não aparece na introdução a Camões e Os Lusíadas. Porém, na polêmica que os autores cearense e pernambucano haveriam de travar dali a três anos, Joaquim Nabuco tocará na

\footnotetext{
177 NABUCO, 1872,p.13. A introdução a Camões e Os Lusíadas parece endossar a análise de Luiz Costa Lima em "Nabuco: trauma e crítica", no qual o autor maranhense defende: "Seria [...] superficial e preconceituoso dizer se que Nabuco não se qualificará para o exercício da crítica porque só tivesse ol hos de admiração para a Europa civilizada. Desqualifica-se, quer se trate de literatura européia ou brasileira, por uma experiência primária que nasce e se desenvolve aqui: a defesa dos que protegem a escravidão, dos que utilizam desde a força bruta ou dos capitães-de-mato até a força sutil da elaboração de leis, funda-se na sinonímia entre ficção, engodo e mentira." (COSTA LIMA, 2002, p.348) O instigante ensaio de Costa Lima será mais bem aproveitado em nosso Capítulo 4.

${ }^{178}$ ALONSO, 2007, p.117.

179 NABUCO, 2010, p.15.
} 
questão da presença da escravidão na literatura brasileira. E, assim, descontado o calor da animosidade, sobre $O$ demônio familiar comentará:

A escravidão é a atmosfera do seu teatro; os seus personagens respiram nela, e desenvolvem-se com perfeita indiferença nessa meio corrompido. [...] Se a escravidão sai abalada do seu drama e da sua comédia, não é que êle tivesse querido atingir êsse fim, é que se vê como ela avilta a literatura que inspira. ${ }^{180}$

Seja como for, Nabuco antevia (na verdade, a opinião era consensual, sobretudo no meio político da Corte) que o trabalho escravo não duraria para sempre, conforme expressara em A escravidão: “[...] o bem é que há de avultar: o crime é uma nuvem que passa, que solta tormentos, mas uma vez exausta deixa o ar mais livre [...],",181 para ratificar em 1872: "O presente no Brazil é uma épocha de transição." ${ }^{\text {182 }}$ Nessas condições, a sociedade escravocrata não poderia fornecer o elemento genúno, característico da identidade nacional à literatura. Mas também se deveria considerar que a escolha desse caminho de retrato social "pecca[ria] por falta de ideal, sem o qual não existem nem letras nem artes", e seria esse filão, "na verdade, a exacta pintura da sociedade de hoje, mas por isso mesmo é destinado á perecer com esta". ${ }^{183}$ E prediz o jovem ensaísta:

Não duvido que venhamos a ter uma abundante literatura patria, mas para isso é preciso, primeiro, que a alma beba amplamente inspirações na nossa natureza e, depois, que a sociedade chegue pela liberdade a tomar sua forma definitiva. Enquanto tais resultados não se produzirem, os Lusiadas como obra-prima de nossa língua, serão a obra-prima de nossa literatura. ${ }^{184}$

\footnotetext{
${ }^{180}$ NABUCO, 1965, p.112.

${ }^{181}$ NABUCO, 2010, p.12.

182 NABUCO, 1872, p.14.

183 NABUCO, 1872, p.14.

184 NABUCO, 1872, p.14.
} 
A discussão em torno da identidade nacional da produção literária portuguesa e brasileira remontava, como vimos, pelo menos, à "polêmica da Minerva fluminense", transcorrida entre 1840 e 1860, da qual participaram Santiago Nunes Ribeiro, Gama e Castro, Abreu e Lima, Joaquim Norberto e outros. Nunes Ribeiro é autor do ensaio de teor nacionalista "Da nacionalidade da literatura brasileira", de 1843, nele argumentando contra a tese de que "as produções intelectuais brasileiras deviam pertencer a Portugal em virtude dos vínculos existentes entre os dois povos", ${ }^{185}$ além de questionar o argumento da identificação nacional de uma literatura pela língua - em concordância com a "teoria portuguesa", que, segundo Afrânio Coutinho, "veio de Garrett e se prolonga por toda a historiografia literária lusa", ${ }^{186}$ critério adotado, afinal, por Abreu e Lima. Todavia, para Nunes Ribeiro: "A literatura é a expressão da índole, do caráter, da inteligência social de um povo, ou de uma época: ora o Brasil tem uma índole, um caráter, uma inteligência social própria; logo tem uma literatura própria, isto é, uma literatura brasileira". ${ }^{187}$

Em Literatura e civilização em Portugal, ensaio escrito nos primeiros meses de 1850 e não publicado em vida do autor, Álvares de Azevedo mostra-se convencido de haver relações muito próximas entre as características de uma sociedade e o caráter de sua produção literária, de modo que, sintetizando em uma frase lapidar: "Mudai as relações do país e a literatura muda". ${ }^{188}$ Uma dessas "relações" que definiriam a identidade de uma literatura seria a língua: "[...] quanto a nosso muito humilde parecer, sem língua à parte não há literatura à parte". ${ }^{189}$ Assim, a literatura portuguesa somente alcança sua autonomia frente à espanhola, quando os poetas de Portugal passam a preferir ou predominantemente expressar-se em português. Para Álvares de Azevedo, Os Lusíadas seria o marco de separação entre uma e outra das literaturas

\footnotetext{
${ }^{185}$ COUTINHO, 1968, p.53.

${ }^{186}$ COUTINHO, 1968, p.32.

187 RIBEIRO in COUTINHO, 1968, p.42.

${ }^{188}$ AZEVEDO, 2000, p.708.

189 AZEVEDO, 2000, p.715.
} 
ibéricas, embora seja “[...] tanta a similitude do parecer [...] que se fosse possível passar por esse tropeço do vário das línguas, pudéramos dizer que essas duas, eram uma só literatura".190 Perante essa argumentação, teria sido impossível ao poeta brasileiro não tocar na questão, muito em voga nos debates literários do País, de a literatura do Brasil separar-se ou não da de Portugal.

Tachando de "ridícula, de mesquinha pequenez" a defesa de Santiago Nunes Ribeiro pela separação e de "secundária" a polêmica que "[...] alguns poetas, e mais modernamente o Sr. Gonçalves Dias parecem ter indigitado: [a] saber, que a nossa literatura deve ser aquilo que ele intitulou nas suas coleções poéticas - poesias americanas", ${ }^{191}$ Azevedo tanto se mostra avesso à ideia de que a mera tematização indianista, como a realizada pelo poeta de 'I-jucapirama", conduziria a uma separação identitária do que se escreve aquém e além-mar, quanto diz:

E demais, ignoro eu que lucro houvera [...] em não querermos derramar nossa mão cheia de jóias nesse cofre mais abundante da literatura pátria [a da ex-metrópole]; por causa de Durão, não podermos chamar Camões nosso; por causa, por causa de quem?... (de Alvarenga?) nos resignarmos a dizer estrangeiro o livro de sonetos de Bocage! ${ }^{192}$

Como podemos observar na passagem acima, ao lado do argumento linguístico, coloca-se o argumento da vantagem cultural para os brasileiros de pensarem sua literatura integrada à de Portugal, para que não pudéssemos chamar "estrangeiros" o poeta d'Os Lusíadas e o de

\footnotetext{
190 AZEVEDO, 2000, p.716.

${ }^{191}$ AZEVEDO, 2000, p.715.

192 AZEVEDO, 2000, p.715.
} 
Rimas. Segue-se o argumento de cunho histórico-sociológico, que, embora se baseie exclusivamente no período anterior a 1822 , ainda se aplicaria ao Brasil independente: ${ }^{193}$

[...] os vezos e usanças das colônias do Brasil eram os mesmos dos Portugueses: a língua foi sempre a mesma. Os poetas, cuja nascença tanto honra ao Brasil, alçaram seus vôos d'águia na mãe-pátria. Com pouca exceção, todos nossos patrícios que se haviam erguido poetas, tinham-se ido inspirar em terra portuguesa, na leitura dos velhos livros, e nas grandezas da mãe-pátria. ${ }^{194}$

Sendo que a polêmica da Minerva fluminense transcorrera entre 1840 e 1860, e Álvares de Azevedo redigira Literatura e civilização em Portugal em 1850, já não nos parece tão heroico assim o esforço do poeta paulista em defender a participação das letras brasileiras na literatura portuguesa, como quer Antonio Candido; ${ }^{195}$ definitivamente, o autor de Noite na taverna, nisso não estava sozinho (como também não o estava Machado de Assis, em sua época).

O professor Acízelo de Souza destaca também dois autores, Sotero dos Reis e Fernandes Pinheiro, cujas obras "são bastante representativas do modo por que se institucionalizou entre nós o culto da literatura portuguesa". ${ }^{196}$ Trata-se, na verdade, de posicionamentos menos radicais, que não conduzem à conclusão de que a literatura produzida no Brasil pertença ou não à de Portugal, mas sim à afirmação da "persistência de um vínculo aditivo entre ambas", ${ }^{197}$ mesmo depois de 1822. No Curso de literatura portuguesa $e$

\footnotetext{
${ }^{193}$ Assim compreendemos porque Álvares de Azevedo polemiza a questão com autor como Gonçalves Dias, o qual, em prefácio às Sextilhas de frei Antão, de 1848, proclamava que "as literaturas brasileira e portuguesa hão de ser duas [...]". (DIAS in COUTINHO, 1968, p.57)

${ }^{194}$ AZEVEDO, 2000, p.716.

195 “[...] lembremos que Álvares de Azevedo foi antinacionalista decidido em matéria de literatura. Segundo ele, a nossa fazia parte da portuguesa e não havia sentido nem vantagem em proclamar a sua identidade específica - atitude destoante de esforço central da crítica do tempo, constituindo um paradoxo que deve ter sido difícil e quase heróico sustentar." (CANDIDO, 1989, p.14)

${ }^{196}$ SOUZA, 2007, p.77.

${ }^{197}$ SOUZA, 2007, p.76.
} 
brasileira, vindo a público em volumes entre 1866 e 1873, Francisco Sotero dos Reis acolhia a língua como critério para estabelecer a necessidade de se estudar as produções literárias dos dois lados do Atlântico juntas. Já Joaquim Caetano Fernandes Pinheiro, com seu Curso elementar de literatura nacional, de 1862, sustentava a coerente posição de que só depois da independência o Brasil passaria a possuir uma literatura que não se confundisse mais com a portuguesa; o romantismo, desse modo, é que iniciaria a produção literária autônoma do País. ${ }^{198}$

A importância do debate se evidencia ao ser retomado por Joaquim Nabuco em 1872 e, em 1873, por Machado de Assis, em "Instinto de nacionalidade". São muitas as coincidências de ponto-de-vista entre o texto nabucoano e o machadiano. Importa saber que o romancista de A mão e a luva conhecia Camões e Os Lusíadas, antes de ser publicado, conforme parece atestar carta que recebeu em 1872: "Se V. quiser ouvir umas folhas de má prosa sobre os Lusíadas [sic] apareça às 7 da noite à rua da Princesa do Catete no 1 , casa sua e de Joaquim Nabuco". 199

Em "Instinto de nacionalidade", afirmava Machado de Assis: "Esta outra independência [a literária] não tem Sete de Setembro nem campo de Ipiranga; não se fará num dia, mas pausadamente, para sair mais duradoura; não será obra de uma geração nem duas; muitas trabalharão para ela até perfazê-la de todo". ${ }^{200}$ Joaquim Nabuco reprovava justamente a solução fácil de uma autenticidade literária nacional encontrada no que propunha o indianismo, nestes termos: "Uma literatura, inspirada pela vida errante das tribos primitivas, que se servisse amplamente de seu rude vocabulário, que não nos descrevesse senão os seus costumes, seria bem uma literatura tupi ou guarani, mas não a brasileira". 201 Isso, em

\footnotetext{
198 Cf. SOUZA, 2007, p.76.

199 NABUCO in ARANHA, 2008, p.91.

${ }^{200}$ ASSIS, 1968, p.136-137.

${ }^{201}$ NABUCO, 1872, p.11.
} 
consonância com o que advogará o amigo Machado, no ano seguinte: 'É certo que a civilização brasileira não está ligada ao elemento indiano, nem dele recebeu influxo algum; e isto basta para não ir buscar entre as tribos vencidas os títulos da nossa personalidade literária". 202 Também para Nabuco é tão descabida a solução apressada de encontrar a nacionalidade literária na cultura indígena quanto a suposição de que a "vida do Brasil começou em 1500; antes existia o seu solo, mas com outro nome e povoado por outra raça. O domínio dessa desapareceu, barbaramente perseguido, é certo, e refugiou-se no interior ainda virgem do país". ${ }^{203}$ Isso posto, surge a pergunta: “[...] e o que tem a sociedade brasileira com as tribos indigenas?"204 Rejeitando "a cor local" como expressão da "originalidade de uma literatura", Nabuco argumenta que, se assim fosse, "Gonçalves Dias seria andaluz do tempo dos sarracenos, Byron seria veneziano ou grego e Shakespeare seria ao mesmo tempo bretão, romano e mouro"205 - último exemplo dos quais a ser recordado por Machado de Assis, em "Instinto de nacionalidade": “[...] perguntarei mais se Hamlet, o Otelo, o Júlio César, a Julieta e Romeu [sic] têm alguma coisa com a história inglesa nem com o território britânico, e se, entretanto, Shakespeare não é, além de um gênio universal, um poeta essencialmente inglês". 206

Para Joaquim Nabuco, consistiria em "preconceito" o suposto dever de "tornar-nos independentes de Portugal, literária, como nos tornamos politicamente". ${ }^{207}$ A proclamação dessa independência em literatura muitos teriam atribuído à obra de Gonçalves de Magalhães, isto é, o ter realizado "a nacionalização das letras patrias", o que também nega Nabuco, em vista da precária qualidade estética de seus textos, incapazes de fundar uma verdadeira e autóctone tradição literária no país. $\mathrm{Na}$ verdade, Joaquim Nabuco defende: 'Escolhendo, pois,

\footnotetext{
${ }^{202}$ ASSIS, 1968, p.138.

${ }^{203}$ NABUCO, 1872, p.11.

204 NABUCO, 1872, p.12.

205 NABUCO, 1872, p.12.

${ }^{206}$ MACHADO, 1968, p.140.

207 NABUCO, 1872, p.15.
} 
os Lusiadas, acredito que não saí do terreno da literatura nacional", ${ }^{208}$ crença que mais se postula na explicitação final dos propósitos de seu livro comemorativo:

Em 1859, em 1864 e em 1865, a Allemanha, a Inglaterra e a Italia celebrárão com festas nacionaes os centenarios de Schiller, de Shakespeare e de Dante. Publicando hoje estas notas, não faço mais do que fizeram os homens de coração desses três países, quando, deixando os campos, vinham ás cidades cobrir de flores as estatuas dos poetas. Eu pago o tributo de uma admiração sempre crescente a Luís de Camões no terceiro centenario de seu poema. ${ }^{209}$

Como se vê, a admiração pessoal pelo poeta renascentista português ganha uma dimensão coletiva: se foram alemães, ingleses e italianos os que homenagearam grandes poetas de suas respectivas nações, Nabuco - um brasileiro - legitima sua homenagem a um poeta português, com base no vínculo cultural entre Brasil e Portugal, mesmo após 1822, e uma dependência literária daquele em relação a este, a que seria desnecessário pôr fim, para não perdermos a obra camoniana como tesouro também dos brasileiros.

Uma e outra dessas ideias encontrarão eco em textos posteriores de outros autores. $\mathrm{O}$ tão nacionalista Sílvio Romero, por exemplo, na História da literatura brasileira, de 1881, ensina que: "O caráter nacional [de uma literatura] não está em se falar em maracás $e$ tangapemas, tampouco está em se lembrar o xiba, o bumba-meu-boi, o samba, etc. Deve estar no sentimento original, no sentir especial do brasileiro",210 para mais adiante esclarecer:

Ao crítico e ao historiador é que compete indagar das condições de nosso nacionalismo. Os poetas não se devem meter nisso. De poeta só uma coisa se pode exigir: é que tenha talento. Quanto ao mais, deve sempre escrever sem se preocupar se é nacional ou não; porque, se preocupar, sê-lo-á à força,

\footnotetext{
${ }^{208}$ NABUCO, 1872, p.15.

209 NABUCO, 1872, p.16-17.

${ }^{210}$ ROMERO, 1978, p.21.
} 
falsificará desde logo a sua intuição. Não é nacional quem o quer; é nacional aquele que a natureza o faz, ainda que o não procure ostensivamente. ${ }^{211}$

Posto que haja diferenças importantes entre o que dissera Álvares de Azevedo, o que dizia Nabuco e o que viriam a dizer Machado de Assis e Sílvio Romero, não se referiria a tais questões a contribuição pioneira do autor pernambucano, assinalada por José Veríssimo, à crítica brasileira? Seja como for, ainda o próprio Veríssimo defenderá ideias muito afins às de Nabuco e Azevedo, no artigo "O que falta à nossa literatura", publicado em fevereiro de 1899 . Aí o crítico paraense postula:

[...] ainda eu hesito em atribuir à nossa literatura o qualificativo de brasileira, [...] pois não sei se é possível a existência de uma literatura inteiramente independente, sem uma língua inteiramente independente também. A língua é o elemento constituinte das literaturas, por isso que ela já é de si mesma a expressão do que há de mais íntimo, de mais individual, de mais característico em um povo. Só têm literatura própria, sua, original, os povos que têm língua própria. Neste sentido, que me parece o verdadeiro, não há literatura austríaca ou literatura suíça ou literatura belga, sem embargo de existirem nesses povos, com uma alta cultura, escritores notáveis de todo o gênero.

Considero, portanto, a literatura brasileira como um ramo da portuguesa $[\ldots] .{ }^{212}$

A passagem aproxima Veríssimo mais ao Álvares de Azevedo de Literatura $e$ civilização em Portugal do que ao Nabuco de Camões e Os Lusíadas, por comungarem os dois primeiros autores da crença na primazia do critério da língua na identificação nacional de uma literatura. Pensando assim e no diagnóstico de que Portugal acabaria dali (fins do século XIX) a pouco tempo desaparecendo numa segunda união ibérica, o crítico paraense chega até a ter a expectativa de que esse acontecimento "nos daria uma enorme superioridade moral sobre os Estados Unidos e as nações hispano-americanas, fazendo-nos na América a única

\footnotetext{
${ }^{211}$ ROMERO, 1978, p.29.

212 VERÍSSIMO, 1977, p.63.
} 
nação de língua e Literatura verdadeiramente nacionais". ${ }^{213}$ Contudo, aquele período finissecular parecia a Veríssimo pouco propenso à constituição da nacionalidade brasileira na literatura, dada a influência estrangeira (não lusófona) que teria eliminado a sinceridade poética de autores como Álvares de Azevedo, Gonçalves Dias, Junqueira Freire, Casimiro de Abreu e outros das décadas de 1850 e $60 .^{214}$

Em “Sobre a formação da literatura brasileira", texto de 1906, José Veríssimo não apenas reproduz que "Não há maior erro do que falar [...] no índio como fator da nossa literatura", 15 mas também insiste no entendimento de que "o português foi, incomparavelmente, o principal agente da nossa formação literária, o que nos deu o precípuo e indispensável instrumento de expressão literária, a língua que é, só por si, o fundamento insubstituível de toda a literatura". ${ }^{216}$ Contudo, diferentemente de todos os autores evocados nessa discussão, são Veríssimo e Romero os únicos a assinalarem a importância dos negros na formação literária brasileira. ${ }^{217}$

Uma década depois de publicar aquele texto, Veríssimo, na introdução a sua História da literatura brasileira, percebe outra realidade:

A literatura que se escreve no Brasil é já a expressão de um pensamento e sentimento que se não confundem mais com o português, e em forma que, apesar da comunidade da língua, não é mais inteiramente portuguesa. É isto absolutamente certo desde o Romantismo, que foi a nossa emancipação literária, seguindo-se naturalmente à nossa independência política. ${ }^{218}$

\footnotetext{
213 VERÍSSIMO, 1977, p.64.

214 Cf. VERÍSSIMO, 1977, p.65.

${ }^{215}$ VERÍSSIMO, 1977, p.71.

${ }^{216}$ VERÍSSIMO, 1977, p.72.

217 Cf. VERÍSSIMO, 1977, p.74. Indaga Sílvio Romero, em seção de sua História da literatura brasileira, dedicada à quinta fase da poesia romântica: "E se a questão é de amor para com as raças que constituíramo nosso povo, por que motivo não se estuda o negro, como se estuda o índio?" (ROMERO, 1977, p.47), sendo que "O predomínio aparente do indianismo na civilização bra sileira é um velho prejuízo [no sentido de preconceito], difícil de extirpar". (ROMERO, 1977, p.49)

${ }^{218}$ VERÍSSIMO, 1977, p.89.
} 
$\mathrm{Na}$ discussão dos demais textos nabucoanos sobre Camões, veremos que o autor pernambucano, a exemplo de José Veríssimo, veio a modificar seu entendimento acerca da literatura brasileira e a relação desta com a portuguesa. De qualquer forma, na introdução a Camões e Os Lusíadas, Joaquim Nabuco acaba por intervir em debate de interesse longevo: intelectuais anteriores (os participantes da "polêmica da Minerva Fluminense" e Álvares de Azevedo), contemporâneos (Machado, Romero e Veríssimo) e até autores do novecentos e ainda do século $\mathrm{XXI}^{219}$ encontraram-se às voltas com a questão relativa à autonomia identitária da literatura brasileira. A proximidade ideológica no tocante a essa questão entre Nabuco, Machado, Romero e Veríssimo - ou, pelo menos, no comum interesse pela questão reforça a noção de uma plataforma crítica que os levou aos quatro a repensar a literatura do País. Cabe aqui também sublinhar que o postulado pertencimento de nossas letras ao sistema literário português ia ao encontro da própria ligação estreita entre intelectuais brasileiros com a cena cultural da ex-metrópole, conforme observamos na primeira parte do capítulo anterior deste trabalho.

Importa balizar, nesse continuum do debate em torno da autonomia ou não da literatura brasileira, a posição de Joaquim Nabuco expressa em 1872. Conquanto tenhamos apontado para a proximidade de pensamento entre o texto introdutório do jovem ensaísta pernambucano e o artigo de Machado de Assis, cumpre frisar que o romancista carioca não tinha então em vista postular o pertencimento da produção literária brasileira à portuguesa, mas apenas salientava como a nacionalidade de nossa literatura ia-se encontrando não na facilidade de temas locais, mas em algo menos palpável, da ordem do instinto. Em síntese, era

\footnotetext{
${ }^{219}$ Mais ultimamente, o professor português de Literatura Brasileira, Abel Barros Baptista, verificou na Formação da literatura brasileira, de Antonio Candido, a sobrevivência de imperativos nacionalistas erguidos como bandeira dos modernistas da década de 1920, traduzidos no estabelecimento da "possibilidade de desconhecer Portugal 'pura e simplesmente', dando esse desconhecimento como resultado natural do processo de 'formação' da literatura brasileira". (BAPTISTA, 2005, p.43)
} 
essa nacionalidade desejável para Machado de Assis. Nabuco também rejeita o indianismo como tema que afirmaria a brasilidade literária, porém, toca em fatores mais concretos que impediriam a realização de nossa autonomia nessa esfera - a escravidão -, resquício do passado colonial. Igualmente são mais concretas as soluções propostas para haver a independência literária no Brasil: o conhecimento e maior convívio com a natureza pátria ${ }^{220}$ e a abolição da escravatura. Tanto Machado quanto Nabuco descartam da questão o elemento da língua, diferentemente do que fizeram Álvares de Azevedo e José Veríssimo.

O fato é que a eleição de Camões para ser homenageado por brasileiro pós-1822 atacou certos brios patrióticos dos corações românticos. Até porque, em 1872, se completava o cinquentenário de proclamação da independência. Na polêmica de 1875 , José de Alencar desmereceu o ensaio de Nabuco com estas palavras: “[...] escreveu um livro cortejando o lusitanismo, e recebeu a correção do Sr. T. Braga."221 Esse veto ao não-nacional, a propósito, infelizmente não parece ter terminado ainda hoje; haja vista o depoimento do professor Luiz Costa Lima: “[...] nunca julguei que o fato de ser brasileiro me obrigasse a só considerar assuntos brasileiros! Isso me parece provinciano, absurdo, em parte responsável por nosso isolacionismo."222 Seja como for, Nabuco em 1872, considerando-se a proximidade de pensamento com José Veríssimo e Machado de Assis, assume postura geracional. E quando alça o quinhentista português à condição de bandeira contrária à literatura oficial do Segundo Império, o indianismo, de fato, conforme ensina Angela Alonso, um dos sustentáculos

\footnotetext{
${ }^{220}$ No ano posterior à publicação de Camões e Os Lusíadas, Joaquim Nabuco viaja para a Europa. Sua estada no Velho Continente o afetou profundamente, inclusive no tocante à visão sobre a paisagem nacional. Em muitíssimo citado trecho de Minha formação, o abolicionista dá a entender que a natureza brasileira já não seria importante para a constituição de uma literatura autônoma, depois da viagem: "As paisagens todas do Novo Mundo, a floresta amazônica ou os pampas argentinos, não valem para mim um trecho da Via Appia, uma volta da estrada de Salerno a Amalfi, um pedaço do cais do Sena à sombra do velho Louvre." (NABUCO, 1981, p.44)

${ }^{221}$ ALENCAR in COUTINHO, 1965, p.60.

222 LIMA, 2002, p.18.
} 
ideológicos do regime monárquico de D. Pedro II, ${ }^{223}$ podemos compreender seu ensaio como um ato político-cultural - de negação ao status quo brasileiro, o que é reforçado pela crítica veemente à escravidão, que acaba por manchar toda uma produção literária do País no século XIX.

\section{1) O discurso no terceiro centenário da morte de Camões:}

\subsection{1) Considerações preliminares:}

Entre a publicação de Camões e Os Lusíadas (1872) e o pronunciamento do discurso por ocasião do terceiro centenário de morte do poeta quinhentista, a 10 de junho de 1880 , sucederam-se fatos na vida de Joaquim Nabuco que merecem aqui menção.

Em 1873, frequentando o Clube da Reforma e contribuindo para o periódico dessa instituição monárquico-liberal (A reforma), Nabuco investe contra a união de Estado e Igreja, em textos como "A invasão ultramontana" e "O partido ultramontano: suas invasões, seus órgãos e seu futuro". Nesse mesmo ano, pela primeira vez, viaja para a Europa, onde visita os principais países do Continente e trava conhecimento com eminências intelectuais do porte de Ernest Renan, George Sand e Hipolythe Taine. A estada na civilisation europeia, naturalmente, afeta o viajante, que frequenta as altas rodas sociais. Nas palavras de Angela Alonso: "Ali se poliu como aristocrata e se converteu em cosmopolita". ${ }^{224}$ Também ali se consolidaram suas ideias monarquistas, depois de, anos antes, ter flertado com o republicanismo, para desgosto e temor do pai. De volta ao Brasil, organiza volume de poemas

\footnotetext{
${ }^{223}$ Cf. ALONSO, 2002, p.56-58.
}

${ }^{224}$ ALONSO, 2007, p.34. 
seus em francês, Amour et Dieu, e se lança como crítico literário e de arte, aproveitando (e ostentando) o que viu na Europa. Nessa atividade, inesperadamente, envolve-se em polêmica com José de Alencar, melindrado pelos comentários do jovem crítico sobre a encenação de $O$ jesuíta. No ano seguinte, o filho de senador do império escreve o drama, também em francês, L'option e torna-se adido em Washington, já que se frustrara, como em 1871, a candidatura a deputado, articulada sempre pelo pai. O senso demasiado pragmático e pouco afeito ao estilo aristocrático de ser dos norte-americanos não tardou a desgostar e entediar Nabuco, que, de volta ao Brasil em 1877, cada vez mais se vai interessando pela questão abolicionista. Em 1878, é nomeado adido em Londres, mas a notícia da morte de Nabuco de Araújo trá-lo de volta ao País. Influências políticas envolvidas com seu pai acabam determinando sua candidatura e eleição para deputado. E é nessa condição que Joaquim Nabuco, em 1880, encaminhou monção para a Câmara Provisória participar oficialmente das comemorações camonianas brasileiras.

O notório camonista de meados do século XIX, Visconde de Juromenha, baseado em antigo documento que consultara na biblioteca da Torre do Tombo, veio a estabelecer o 10 de Junho de 1580 como o último dia de vida do autor d'Os Lusíadas. A data tornar-se-ia não apenas o Dia de Camões, mas também o de Portugal, da Língua e das comunidades portuguesas. A importância dessa descoberta é avaliada nas seguintes palavras de João Gaspar Simões:

Só uma data é certa na vida de Luís de Camões - a data da sua morte. Por isso mesmo os Portugueses se concertaram para conferir ao dia 10 de Junho - a única data certa na vida do poeta, 10 de Junho de 1580, data da sua morte - atributos que fazem dela, dessa data [...] a data mais solenemente comemorativa desse mesmo povo. ${ }^{225}$

${ }^{225}$ SIMÕES, 1981, p.85. 
Em 1880, os 300 anos de morte de Luís Vaz de Camões foram amplamente lembrados e comemorados tanto em Portugal quanto no Brasil. Todavia, se lá os festejos camonianos marcaram-se pela predominância das cores antimonárquicas e republicanas - efeito do esforço empolgado de Teófilo Braga e seus asseclas -, aqui o evento apresentou caráter, em linhas gerais, entre o conservador e o reformista, este no propósito de, segundo Angela Alonso, “acentuar a continuidade cultural com a metrópole européia e manifestar seu desdém pelo indianismo romântico, a marca do Segundo Reinado", 226 ou ainda: "A recuperação de Camões auxiliou os contestadores [do status quo do regime imperial] a conectarem o Brasil com sua raiz européia, dando-thes uma matéria alternativa ao indianismo saquarema para recompor o identidade nacional brasileira."227 Nesse propósito, Joaquim Nabuco seria nome muitíssimo adequado para discursar nas comemorações organizadas pelo Real Gabinete Português de Leitura do Rio de Janeiro. Como vimos na parte anterior deste capítulo, a introdução a seu ensaio de 1872 (esse livro era uma das razões alegadas para o convite ao deputado pernambucano) professava a ligação literária, mesmo após 1822, entre a ex-colônia e a exmetrópole, e ainda refutava a solução indianista como representante da genuína literatura brasileira. Ademais, ainda nos apropriando das palavras de Alonso, em seu modus vivendi político e intelectual, Nabuco sempre "equilibrou-se entre reforma e tradição", ${ }^{228}$ estando, pois, em perfeita sintonia ideológica com o evento.

Seja como for, o republicanismo também marcou as comemorações camonianas brasileiras. Aliás, esses defensores da mudança de regime de governo no Brasil ganhavam, na época, cada vez maior força política no País. E, afinal: Foram os republicanos que mais se mobilizaram nas comemorações do terceiro centenário da [morte] do poeta em 1880 . No

\footnotetext{
${ }^{226}$ ALONSO, 2007, p.120.

227 ALONSO, 2002, p.289.

${ }^{228}$ ALONSO, 2007, p.16.
} 
Brasil, houve competição em torno de qual a verdadeira e digna leitura da obra",229 a exemplo das conferências de Miguel Lemos, Teixeira Mendes e Clóvis Beviláqua. Tal contexto decerto alegrava Teófilo Braga, que confessaria sentir nessas comemorações de aquém-mar "o mesmo sentido democrático que em Portugal, a mesma aspiração para uma renovação futura",230 convicto o integrante da Geração de 70 portuguesa de que o "Brasil só póde ser grande como povo civilizado quando se reorganisar em uma Republica federal', libertando-se de uma "pressão centralista irracional e inefficaz"231 que seria o regime monárquico de D. Pedro II.

À parte a organização do evento no Rio de Janeiro contar com instituição (o Real Gabinete) que tinha por presidente Teófilo Braga e por primeiro-secretário Ramalho Ortigão, as comemorações camonianas na Corte brasileira tiveram semelhanças notáveis com as realizadas em Portugal. Se Alexandre Cabral defende que o sentimento de nacionalidade, patriotismo e admiração pelo poeta maior da pátria suplantou o cariz político-partidário (antimonárquico e republicano) das comemorações camonianas em Portugal, inclusive repreendendo Eduardo Lourenço por ter-se referido ao evento como "comemoração teofiliana-jacobina",232 em artigo de 1972, Marcelo Corrêa Sandman, mais recentemente, noticia, quanto ao Brasil, a ampla adesão de várias camadas e setores da sociedade (políticos, intelectuais, escritores, poetas, comerciantes) às comemorações camonianas, conforme nos fornece disso dimensão em artigo de 2003:

Do Imperador D. Pedro II aos empregados da Relojoaria E. J. Gondolo, da peça teatral de Machado de Assis e do discurso de Joaquim Nabuco ao prato do dia do Grand Restaurant Oliveira, o nome do poeta circulou amplamente, numa explícita demonstração de sua popularidade entre nós. ${ }^{233}$

\footnotetext{
${ }^{229}$ ALONSO, 2002, p.288.

230 BRAGA, 1891, p.300.

231 BRAGA, 1891, p.303.

232 Cf. CABRAL, 1973, p.126-127.

${ }^{233}$ SANDMANN, 2003, p.204.
} 
E se um Antero de Quental e um Oliveira Martins criticaram a índole patrioteira, positivista e republicana na homenagem a poeta que teria sido, de fato, patriota, mas embebido na fé católica e monarquista, e, ademais, símbolo inadequado para uma tentativa de renascimento da glória da nacionalidade portuguesa, ${ }^{234}$ não faltou quem nestas plagas semeasse a polêmica. Pelo menos Araripe Júnior incomodou-se com as comemorações camonianas brasileiras, nelas enxergando a negação ou retrocesso da autonomia cultural do Brasil, que parecia assim demonstrar nostalgia dos tempos de colônia. Além disso, dois dias depois de o Real Gabinete Português de Leitura publicar, na Gazeta de notícias de 9 de março, o convite a Joaquim Nabuco para ser o orador oficial, portugueses residentes no Rio de Janeiro protestavam contra a escolha de um brasileiro para discursar sobre um poeta de Portugal, sobretudo porque haveria portugueses no Brasil tão ou mais aptos à incumbência do que o convidado. Os doutores Francisco Ferraz de Macedo e Figueiredo Magalhães parecem ter sido os mais revoltados; um e outro chegaram a publicar em volume sua indignação xenófoba e, segundo alguns, despeitada: o primeiro, o Desabafo patriótico e o tricentenário de Camões no Rio de Janeiro, e o segundo, Camões e os portugueses no Brasil: reparos críticos.

No primeiro artigo publicado dois dias após tomar conhecimento da escolha do Real Gabinete, artigo coligido no volume, Ferraz de Macedo desabafava patrioticamente:

[...] como póde harmonisar-se isto?... É crivel que uma associação genuinamente portugueza (e honra seja feita a quem a recebe com respeitosa hospitalidade), que escrupulisa tencionalmente na admissão de seus socios effectivos e nos seus accionistas, não os aceitando quando não sejam patricios, tenha para representante, ou vá buscar para represental-a em

\footnotetext{
${ }^{234}$ Cf. pp. 32 a 34 desta monografia, em que se discute o que era Camões para Oliveira Martins e Antero de Quental.
} 
assumpto puramente patriotico um filho de outro paiz, embora amigo, irmão affetuoso pelo sangue, pelos costumes e lingua e habitos e aspirações e tudo, enfim?... Não comprehendo! ${ }^{235}$

Basicamente, a contestação se pautava em dois pontos: 1) o caráter nacional das comemorações camonianas, organizadas por instituição portuguesa em homenagem a poeta português; 2) a desqualificação do orador escolhido para tratar do assunto. Pois se Ramalho Ortigão, em resposta aos descontentes, referia-se a Camões e Os Lusíadas - suposta prova da qualificação do convidado - para legitimar a escolha de Nabuco, o dr. Ferraz de Macedo dizia acerca desse ensaio:

[...] diz elle [Nabuco, em Camões e Os Lusíadas] que deixou de parte os estudos bibliographicos, desconhecendo quasi tudo que a respeito de tal assumpto se tinha até àquella epocha escripto; diz finalmente que aquella critica, manifestada em seu livro, não tem historico, nem applicação ao estudo, nem exame confrontativo, nem competencia de authoridade, nem sentimentos patrios, nem fundos de verdade, nem nada, nada, nada, só tem words, words, words!... porque é um livro escripto, como elle muito bem diz, tendo por base um planeta pingue de suas proprias impressões. ${ }^{236}$

E conclui seu Desabafo patriótico, retomando o sentido de ofensa do convite ao significado nacional das comemorações, ofensa que seria igual à que os brasileiros sentiriam, caso soubessem que um estrangeiro havia sido escolhido para orador de cerimônia de homenagem a poeta do Brasil. E insiste em tom dramático:

[...] julgo que é uma violação aos direitos patrioticos, um insulto arremeçado bruscamente á face do bom-senso, uma bofetada na rainha da sciencia, um tiro na dignidade e aptidão de sessenta a setenta mil portuguezes presentes, um cartel de desafio ao dever, um acoroçoamento degradante para o cidadão de qualquer povo do mundo, uma monstruosidade inqualificavel, uma

\footnotetext{
${ }^{235}$ MACEDO, 1880, p.39-40.

${ }^{236}$ MACEDO, 1880, p.62.
} 
coisa... uma coisa para hi sem nome por ora, porque é nova e unica entre nós! $!^{237}$

O Desabafo patriótico de F. Ferraz de Macedo publicou-se em duas edições, antes de Nabuco proferir o discurso, a 10 de junho de 1880. O compatriota dr. Figueiredo Magalhães publicou seu protesto em volume depois desse dia. Além de também coligir artigos e manifestos veiculados em jornal, em torno da legitimidade do convite do Real Gabinete, Magalhães analisa o discurso de Nabuco, ressaltando problemas de compreensão histórica e literária, bem como de gramática, argumento que se associa ao de caráter xenófobo-patriótico para contestar a escolha do abolicionista pernambucano para a honrosa função. Diferentemente do dr. Macedo, o autor de Camões e os portugueses no Brasil não critica apenas o orador, mas também Teófilo Braga, ambos considerados "réus de alta traição litteraria". ${ }^{238} \mathrm{O}$ propósito dessas páginas se esclarece nestes termos, como protesto "do alto da minha insufficiencia contra a rasa annullação de todos os patricios, porque conheço alguns que muito bem podiam salvar-nos da vergonhosa penuria litteraria a que o proprio atheneu officialmente condemnou a colonia inteira!",239 com o fim de

[...] dar uns açoites no discurso official do centenario camoneano, celebrisado nesta cidade pela directoria do Gabinete Portuguez de Leitura, e correr a pau o que aleivosamente se julga, diz, e escreve aquém e além mar a respeito da colonia portugueza no Brazil; mas a rir e galhofando, como quem dá pancadinhas d'amor no seu bem querido, misturando apenas alguns beliscões pelo meio da brincadeira para quebrar a monotonia das graçolas insulsas. ${ }^{240}$

\footnotetext{
237 MACEDO, 1880, p.171.

238 MAGALHÃES, 1880, p.30.

239 MAGALHÃES, 1880, p.9.

240 MAGALHÃES, 1880, p.9.
} 
A proposta do volume, portanto, era comprovar, mediante análise do discurso já ouvido e disponível para leitura, que a escolha do orador tinha sido um equívoco. Magalhães revisita os argumentos patrióticos (diríamos nós, xenófobos) expressos em artigos anteriores à solenidade e procura reforçá-los com os linguísticos, afirmando que Joaquim Nabuco teria falado, à ocasição, "n'um portuguez sui generis","241 eivado de "alterações phonicas, morphologicas e syntaticas, que abalam profundamente as cellulas glotticas do organismo grammatical da lingua portugueza, e que desfiguram o caracteristico da sua physionomia real'" ${ }^{242}$ Dentre essas alterações, tão dramaticamente qualificadas, encontrar-se-ia a escrita da conjunção 'si', em vez de 'se'; questões às quais se dedica capítulo intitulado "Camões em língua nova". Quanto aos argumentos ditos patrióticos, o autor assevera: "Mas Camões é tanto - o poeta do Brazil - como Gonçalves Dias é - o poeta de Portugal."243 E também: "O portuguez não póde nem deve intrometter-se nas cousas brazileiras; e o brazileiro não deve nem póde promiscuar-se nas cousas portuguezas". 244

No Rio de Janeiro, capital do Império, o Real Gabinete Português de Leitura apenas organizou o evento que talvez tenha sido o de maior destaque em todo o território nacional, pois outras províncias, como São Paulo, Pernambuco, Bahia e Rio Grande do Sul, também manifestaram reverência à data. ${ }^{245} \mathrm{~A}$ instituição luso-brasileira, sediada na Corte, envolveu célebres nomes do País e de Portugal. Encomendou a Machado de Assis uma peça, que veio a

\footnotetext{
${ }^{241}$ MAGALHÃES, 1880, p.11.

242 MAGALHÃES, 1880, p.33. Gilberto Freyre chegou a considerar a questão em pequeno texto, intitulado "Secretas da polícia gramatical". Às "zangadas notas de um hoje desconhecido mestre de gramática contra o 'português errado' de Joaquim Nabuco", (FREYRE, 2010, p.31) o autor de Ordem e progresso defende o conterrâneo abolicionista, argumentando, em síntese, que "Os gramáticos desaparecem depressa e os renovadores das línguas tornam-se vida. É que seus supostos erros são mais fortes que as regras da gramática". (FREYRE, 2010, p.32) Na língua portuguesa, segundo Freyre, emparelhar-se-iam a esse respeito: "Como Eça em Portugal. Como Nabuco no Brasil." (FREYRE, 2010, p.32)

243 MAGALHÃES, 1880, p.45.

244 MAGALHÃES, 1880, p.53.

245 Segundo Wilson Martins, "[...] comemorava-se em 1880 o tricentenário da morte de Camões, dando lugar, em todo o país, a fervorosas solenidades literárias e cívicas. O símbolo de todas elas pode ser a cerimônia promovida no Rio de Janeiro pelo Gabinete Português de Leitura [...]". (MARTINS, 1983, p.216. vol.1) Para notas sobre as comemorações realizadas em outras províncias do Brasil, cf. MARTINS, 1983, p.217-218. Vol.1.
} 
ser o Tu, só tu, puro amor; hinos a Carlos Gomes, Artur Napoleão e Leopoldo Miguez - obras a serem encenada e executadas especialmente no período das comemorações. Também preparou edição d'Os Lusíadas, cujo prefácio (na verdade, um escorço biográfico de Camões) Ramalho Ortigão redigiria, sendo que a revisão do poema e as notas filológicas ficariam a cargo de Adolfo Coelho. Programou a inauguração da pedra fundamental de uma biblioteca, defronte à qual estariam as estátuas de Camões e de D. Henrique. E o deputado Joaquim Nabuco proferiria o discurso, perante, dentre outras figuras importantes da sociedade e da política brasileiras, o imperador D. Pedro II e a imperatriz Teresa Cristina.

Podemos apreciar o valor desse discurso para próprio autor no fato de este tê-lo feito integrar, como texto de abertura, o volume Escritos e discursos literários, publicado em 1901. Acresce que certa frase dita naquela noite de 10 de junho de 1880 , muito aplaudida por sinal, é repetida em mais de um texto; na conferência "O espírito de nacionalidade na história do Brasil', pronunciada nos EUA dias após a primeira sobre Camões das que proferirá o então embaixador entre 1908 e 1909, lemos: 'Parece natural sequencia falar do Brazil, depois de me haver occupado dos Lusiadas, uma vez que o Brazil e os Lusiadas são as duas grandes obras de Portugal."246

Entre o texto que se imprimia em 1880 e o de 1901, encontramos modificações diversas: de pontuação, paragrafação, vocábulo, supressão de palavras, sintagmas, frases, parágrafos inteiros etc. Maximiano de Carvalho e Silva, em texto sobre os estudos camonianos de Joaquim Nabuco, ao comentar as alterações de forma e conteúdo do discurso, incita a realizar-se "cuidadosa análise, a partir do conhecimento das crises de pensamento por que passou [o autor] ${ }^{2247}$. De fato, algumas supressões parecem indicar terem decorrido, por exemplo, da reconversão de Nabuco ao catolicismo, processo que se inicia, depois da

\footnotetext{
${ }^{246}$ NABUCO, 1911, p.121. (grifo nosso)

${ }^{247}$ CARVALHO E SILVA, 1980, p.19.
} 
Proclamação da República, num dos períodos de exílio na Inglaterra, mais exatamente na igreja jesuíta de Farm Street, em Londres, e se consolida entre 1892 e 93, quando escreve Foi voulue. Comparemos os trechos; primeiro, o em conformidade com a edição fac-similada de 1880:

O morticinio dos Judeos, o trafico de escravos, a Inquisição com os seos Autos da Fé, as intrigas Hespanholas, o despotismo grosseiro de um rei fanatisado pelos Jesuitas, as pestes que se repetem, a alegria que desapparece no meio da miseria crescente, eis o quadro de Lisbôa durante longos annos. ${ }^{248}$

Agora o mesmo trecho correspondente em sua versão de $1901:^{249}$

O morticínio dos judeus, o tráfico de escravos, a Inquisição com os seus autos da fé, as intrigadas espanholas, o despotismo [xxxx] de um rei

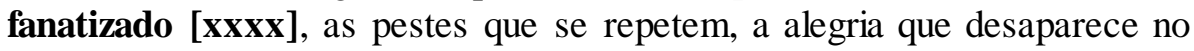
meio da miséria crescente, eis o quadro de Lisboa durante longos anos.

Não consideremos as diferenças de ordem ortográfica, mas, sobretudo a estilística ("grosseiro" é suprimido na versão posterior; seria descartável, perante palavra de carga semântica negativa, como "despotismo"), que sugere a transformação ideológica: elimina-se "pelos Jesuitas", talvez para não comprometer a ordem, da qual numa das igrejas Joaquim Nabuco ouvira o chamado à reaproximação da fé católica. Seja como for, infelizmente, não nos deteremos nessa interessante questão ecdótica. E para os propósitos da análise empreendia

\footnotetext{
248 NABUCO, 1980, p.13.

249 Consultamos a edição do Instituto Progresso, volume IX das Obras completas da Joaquim Nabuco, de 1949. Importa aqui assumir não dispormos de conhecimento de crítica textual suficiente e necessário para uma análise comparativa verdadeiramente qualificada.
} 
neste capítulo, recorremos à versão fac-similada de 1880 . De todo modo, cada citação terá em nota seu correspondente transcrito na versão posterior, conforme edição de 1901.

Mas Joaquim Nabuco expressou seu entusiasmo pela data comemorativa também em versos, tendo escrito, talvez dentre outros, estes dois sonetos publicados em 1880 e transcritos abaixo:

\section{APOTEOSE}

Ele foi um artista soberano

E só teve na arte um ideal:

Era a pátria, por isso Portugal

Que ele amou com alma de romano,

A quem disse, mirando-o no Oceano:

"Podes morrer, que eu torno-te imortal", É hoje o vasto, o imenso pedestal

Do vulto do poeta sobre-humano.

Nesse bronze que os tempos não consomem

Ele paga uma dívida de glória,

A maior que um país deveu a um homem.

E de joelhos no chão da sua história,

Lembrando-se da grande ingratidão

"Pede ao Deus dos Lusíadas" - Perdão! ${ }^{250}$

\section{INÊS E CATARINA}

Duas mulheres chegam-se medrosas

Para perto da estátua, cuja fronte

A manhã que desperta no horizonte

Enche de claridades jubilosas.

Vestem ambas as roupas gloriosas

Cujos fios de luz não há quem conte.

Mas quem são essas formas vaporosas,

Como as névoas que descem sobre o monte?

Uma traz "as ervinhas" com as flores

Que ela colheu na fonte dos amores

A quem "depois de morta a fez rainha"!

${ }^{250}$ NABUCO apud LEÃO, 1953, p.3-4. 
A outra, que era a vida, era o desejo

Que enchia a grande alma que ele tinha

Noiva de sua glória - traz-lhe um beijo. ${ }^{251}$

Vale comentar esses poemas brevemente, antes de discutirmos o discurso pronunciado em 1880.

Ambos os sonetos deixam patente o cunho comemorativo, na imagem das três figuras - Portugal, no primeiro; Inês de Castro e Catarina de Ataíde, no segundo -, as quais rendem homenagem ao poeta representado em estátua, provavelmente, aludindo-se à que existe em Lisboa, ponto apoteótico das comemorações do tricentenário em Portugal. Verdade seja dita, são versos bastante convencionais; aproveitam, no que se refere ao "Apoteose", elementos batidos do imaginário camoniano: o patriotismo máximo do poeta, recompensado pela ingratidão da pátria imortalizada n'Os Lusíadas. Mas as comemorações significariam um pedido humilde e penitente de perdão ao autor quinhentista. Podemos destacar naquele primeiro poema transcrito a divinização de Camões, a quem Nabuco atribui caráter "sobrehumano", e chama-o de "Deus dos Lusíadas", bem como se refere a um "vasto, imenso pedestal", o próprio reino português, sobre o qual se põe a estátua do poeta, reverenciada pela nação "de joelhos".

Quanto ao segundo soneto, a questão é de puro reconhecimento, por parte de uma figura histórica - Inês - que se sobressai na narrativa épica camoniana como protagonista de uma das passagens mais célebres e comoventes da literatura portuguesa; e também reconhecimento por parte de outra figura histórica - Catarina -, mas esta tornada inspiração para os melhores versos amorosos escritos em nosso idioma. No poema, ambas reconhecem e agradecem a imortalidade que lhes conferiu o estro de Camões.

${ }^{251}$ NABUCO apud LEÃO, 1953, p.4. 
Veremos adiante que os dois sonetos contêm algo assinável da recepção nabucoana da vida e obra do quinhentista português, àquela altura; a valorização da figura de Inês na epopeia, a representação de ideais patrióticos, ao lado do amor como tema fulcral da poesia camoniana, e também de proximidade do poeta maior da língua portuguesa com a antiguidade, aqui - acreditamos que por força da rima - representada pela expressão "alma de romano", e não, como conviria mais, em se tratando do que defendeu Nabuco em prosa, "de grego".

\subsection{2) O que propõe o discurso:}

[...] por muitos seculos ainda o teo Centenario reunirá em torno das tuas estatuas, espalhadas pelos vastos dominios da lingoa Portugueza, as duas Nações eternamente tributarias da tua gloria, que unidas hoje pela primeira vez pela paixão da Arte e da Poesia, acclamam a tua realeza electiva e perpetua, e confundem o teo genio e a tua obra n'uma salva de admiração, de reconhecimento e de amor, que há de ser ouvida no outro seculo! ${ }^{252}$

Essas palavras acima transcritas finalizam o discurso de 1880. Aí temos em síntese a expressão do cunho de celebração de um centenário que entusiasmou portugueses e brasileiros num grau que esteve muito longe de conhecer o ano de 1872. Em torno de Camões, duas Nações eternamente tributárias da glória desse poeta, Brasil e Portugal, uniam-se não em nome de um processo político-econômico de colonização, mas sim em nome da paixão da Arte e da Poesia. Não é difícil antever, após a leitura desse trecho, a permanência de uma imagem do poeta quinhentista como herói de sua nacionalidade, abarcadas - pelo menos em certa medida - ex-metrópole e ex-colônia, no discurso de 1880 , segundo o qual, aliás, o prestígio de Camões teria chegado a tal patamar que "Portugal pode 
desapparecer, dentro de seculos, submergido pela vaga Européa",253 e o "Brazil pode deixar, no decurso de milhares de annos, de ser uma nação latina, de fallar a [...] lingoa [portuguesa]", ${ }^{254}$ que o poeta, mesmo assim, "viverá intacto nos Lusiadas, como o de Homero na Illiada".255

E, sendo assim, tanto em 1872 quanto em 1880, temos um Joaquim Nabuco convicto da proximidade do quinhentista português com a cultura helênica, enunciando afirmações e apreciações que vão desde algumas canções camonianas parecerem ter sido "escriptas por um grego, de naturaes que são", 256 ou ao comparar Os Lusíadas à escultura e à arquitetura da Grécia Antiga. Eis aí, portanto, de novo ferida a tecla da homerização do poeta quinhentista, que a recepção crítica camoniana do século XIX encampou. Nesse aspecto, não obstante todo o caráter patriótico do poeta do século XVI igualmente destacado pelo orador, este também procura assinalar a universalidade do nome e da obra camoniana. É curioso notar que o deputado pernambucano chega a especular o que teria acontecido à obra do quinhentista português, caso este tivesse entrado em contato direto com a renascença italiana, no próprio solo que foi berço dessa tentativa de restaurar a cultura Greco-latina. Para Nabuco, Camões receberia influências, alcançando uma formação artística capaz de levá-lo a produzir outras obras-primas, além d'Os Lusíadas. Conquanto não tenha isso ocorrido, o poeta português veio a conquistar a universalidade que um suposto herdeiro autêntico do espírito grego não deixaria de conquistar.

Universalidade e nacionalidade: a tensão que norteia muitas considerações no ensaio de 1872 reaparece no discurso de 1880 . Em passagem deste que talvez recorde capítulo de

\footnotetext{
253 NABUCO, 1980, p.29. "Portugal pode desaparecer submergido pela vaga européia" conforme NABUCO, 1949, p.23.

${ }^{254}$ NABUCO, 1980, p.29. "O Brasil pode deixar de ser uma nação latina, de falar a tua língua [de Camões] conforme NABUCO, 1949, p.23.

${ }^{255}$ NABUCO, 1980, p.29. "viverá intacto nos Lusíadas, como o de Homero na llíada" conforme NABUCO, 1949, p.23.

${ }^{256}$ NABUCO, 1980, p.15. "escritas por um grego, de naturais que são" conforme NABUCO, 1949, p.10-11.
} 
Viagem na minha terra, em que o narrador garrettiano afirmava que Dante 'tinha fé em Deus", Goethe "no cepticismo" e Camões "na sua pátria", ${ }^{257}$ Joaquim Nabuco também diferencia o "trabalho de composição" d'Os Lusíadas frente à Divina comédia e às obras do grande poeta alemão. Para o orador, o poema camoniano "não nos revela, como o da composição da Divina comédia, nenhum soffrimento tragico do espirito, debruçado sobre os abysmos da sua propria allucinação, querendo seguir com os olhos fechados a restia de luz que precede a Dante nesse Inferno", 258 nem "nos revela [...] a liberdade serena com a qual Goethe olha como naturalista para o homem, autor das suas proprias desgraças moraes, do seu proprio destino intellectual, desprezando idealmente a vida n'uma illusão inexplicavel". ${ }^{259} \mathrm{E}$ conclui o deputado pernambucano de reflexões tão obscuras, para não dizer quase ininteligíveis: "Os Lusiadas não resumem o homem, nem a vida; não são o espelho do Infinito subjectivo, nem o da Natureza; elles são como obra de arte, o poema da patria, a memoria de um povo., 260

O deputado pernambucano também chega discorrer sobre a preocupação do quinhentista português, nos últimos anos de vida, com os destinos da pátria, maior do que a preocupação com a posteridade de seu próprio nome - preocupação marcada pelo ceticismo e que reunia indissociavelmente o reino e o império e a epopeia que cantava toda a glória da história portuguesa:

Nesse momento, Camões não separou a patria do poema, os Lusiadas de Portugal. O poeta das Orientáes e de Hernani assiste em vida á sua immortalidade. Mas como poderia Camões acreditar que a gloria succederia á miseria e á indifferença, no meio das quaes elle morria? Não, o poema não duraria mais do que a patria. E si durasse? Á confiança infundada que elle teve na hegemonia Portugueza correspondia a certeza, tambem infundada, da

\footnotetext{
${ }^{257}$ GARRETT, 1963, p.32. vol.I.

258 NABUCO, 1880, p.20. Trecho suprimido na versão de 1901.

259 NABUCO, 1880, p.20. Trecho suprimido na versão de 1901.

${ }^{260}$ NABUCO, 1980, p.20. Trecho suprimido na versão de 1901.
} 
eterna aniquilação de Portugal. Pois bem, morto Portugal, si os Lusiadas the sobrevivessem, o poeta já via o poema vertido para o Hespanhol... ${ }^{261}$

Todavia, graças a, dentre outros fatores, a Inquisição e o absolutismo que, após o reinado de Filipe II, prejudicaram o progresso interno em favor de um crescimento externo, a Espanha não absorvera cultural e politicamente Portugal, mantendo-se este como nação viva. E pergunta o orador: "O que é a celebração deste Centenario, senão a prova de que Portugal não morreo de todo em 1580, mas somente atravessou a morte, e de que os Lusiadas não foram o tumulo nem da raça nem da lingoa?"262 Fosse como fosse, para Nabuco, a derrota em Alcácer Quibir e a União Ibérica converteram a epopeia camoniana na "[...] patria do Portuguez, como a Biblia é a patria do Israelita e o Corão a do Musulmano". ${ }^{263}$

No que se refere à vida do quinhentista português, Joaquim Nabuco não adota a imagem republicano-positivista que, em Portugal, Teófilo Braga estava explorando: a de um poeta, nos seus últimos anos, na extrema pobreza, vítima da indiferença e do descaso de uma monarquia insensível à verdadeira arte. $\mathrm{O}$ orador até se refere, logo no início do discurso, ao 10 de junho de 1580, quando "Luiz de Camões expirava em Lisbôa, na mais completa miseria, ao desamparo de todos, abandonado até de si mesmo". ${ }^{264}$ Entretanto, contrasta a pequenez dessa situação de infortúnio, da miséria de uma vida com a grandeza da glória

\footnotetext{
${ }^{261}$ NABUCO, 1980, p.25. “Naquele momento, Camões não separou a pátria do poema, os Lusíadas de Portugal. O poeta das Orientais e de Hernani assiste em vida à sua imortalidade. Mas como poderia Camões acreditar que a glória sucederia à miséria e à indiferença no meio das quais êle morria? Não, o poema não duraria mais do que a pátria. E se durasse? À confiança infundada que êle teve na hegemonia portuguêsa correspondia à certeza, também infundada da eterna aniquilação de Portugal. Pois bem, morto Portugal, se os Lusíadas Ihe sobrevivessem, o poeta já via o poema vertido para o espanhol..." conforme NABUCO, 1949, p.19-20.

${ }^{262}$ NABUCO, 1980, p.26. "Que é a celebração deste centenario, senão a prova de que Portugal não morreu em 1580, mas sómente atravessou a morte, e de que os Lusiadas não foram o tumulo e sim o novo berço da raça e da lingua?" conforme NABUCO, 1949, p.20.

263 NABUCO, 1980, p.26. "a pátria do português, como a Bíblia é a pátria do israelita e o Corão a do muçulmano" conforme NABUCO, 1949, p.20.

${ }^{264}$ NABUCO, 1980, p.7. "Luís de Camões expirava em Lisboa, na mais completa miséria, ao desamparo de todos, abandonado até de si mesmo" conforme NABUCO, 1949, p.3.
} 
imortal que o gênio conquista com sua obra. "O homem é o nome", ${ }^{265}$ define o orador, e a "parte individual da nossa existencia, si é a que mais nos interessa e commove, não é por certo a melhor. Alem desta, há outra que pertence á patria, á sciencia, á arte". ${ }^{266}$ Essa parte existencial, de interesse amplo, dos grandes homens da história celebrar-se-ia, notadamente, nos centenários, "grandes renovações periodicas dessa posse perpetua" ${ }^{267}$ de um nome.

Um dos pontos mais significativos desse discurso com relação a Camões e Os Lusíadas é a mudança de postura, no que se refere a dados biográficos do poeta quinhentista. Em 1872, era o autor pernambucano mais assertivo e, aparentemente, menos cônscio das dúvidas em torno da vida de Camões. Em 1880, seu texto contém marcas patentes da consciência de que a biografia camoniana estava muito longe de ser ponto pacífico entre os estudiosos. Todavia, uma concepção permanecia ao longo daqueles oito anos: a apologia ao conteúdo lendário, em prol da maior simpatia popular pelo poeta e mais disseminado interesse em o ler. No ensaio de juventude, Nabuco sustentava a tese de que apenas tendo amado verdadeiramente uma mulher (D. Catarina de Ataíde) é que Camões poderia ter escrito versos amorosos tão comoventes. Essa tese, em 1880, passa a ser assumida como "ilusão", que seria melhor manter para não ficar um vazio que outra postulação não preencheria. Desse modo, o orador, que em 1872 estabelecera a oposição entre a "escola histórica" e o imaginário popular, sendo partidário deste, mantinha-se firma nessa sua proposta de compreensão biográfica e literária.

O deputado abolicionista também abandonava a informação de uma única Catarina de Ataíde, honrada pelo amor de tal gênio, para noticiar a existência de outras duas homônimas e contemporâneas, mas sem tomar partido de nenhuma delas. Sendo assim, mais

\footnotetext{
${ }^{265}$ NABUCO, 1980, p.8. "O homem é o nome posthumo" conforme NABUCO, 1949, p.2.

${ }^{266}$ NABUCO, 1980, p.8. "parte individual da nossa existência, se é a que mais nos interessa e comove, nãoé por certo a maior. Além desta, há outra que pertence à pátria, à ciência, à arte" conforme NABUCO, 1949, p.3.

${ }^{267}$ NABUCO, 1980, p.8. "os centenarios são as grandes renovações symbolicas dessa posse perpetua" conforme NABUCO, 1949, p.2.
} 
responsavelmente, o orador matiza outra concepção exposta em 1872, quando fizera implicar genialidade e infortúnio. O agora deputado pernambucano vem a propor uma oposição entre infortúnio da vida e imortalidade do gênio, esta uma sublimação daquele. Consoante a lógica desses termos, Nabuco distingue o homem do poeta; e se o homem Camões, durante o desterro no Oriente, teria sido contaminado pela degradação moral de um império em decadência, o poeta Camões atravessava esse tempo protegido na sua concentração patriótica em escrever Os Lusíadas. Eis aí outra elaboração distinta do que lemos no ensaio de 1872, que nos dizia de um Camões estoico, um herói da ética, sempre movido por elevados valores e sentimentos, conquanto tivesse, segundo o autor, a fraqueza de não levar às últimas consequências sua originalidade e, desse modo, obedecendo aos preceitos poéticos de seu século.

No discurso de 1880, Joaquim Nabuco não se detém sobre a mitologia clássica, não problematiza a coexistência desta com o catolicismo n'Os Lusíadas e tampouco recrimina Camões por ter imitado Virgilio, não assumindo o quinhentista português, desse modo, a plenitude de sua genialidade, deixando de ser ao máximo original. Quanto aos dois primeiros aspectos, sem termo de comparação, ou nos resta o silêncio sobre isso ou observar que se trata de dois estudos - o discurso e o ensaio - de características discursivas e contextos completamente diferentes. A total liberdade de extensão de um livro permite abordagem e profundidade incomparáveis ao que se dispõe num discurso, limitado ao tempo de parcela de uma solenidade. Um recorte, portanto, impunha-se em 1880. Quanto à questão da imitação, o que parece é ter havido um amadurecimento crítico por parte de Nabuco, ciente ou mais ciente da imitatio $^{268}$ como processo incontornável da poética clássica.

\footnotetext{
${ }^{268}$ Afrânio Coutinho esclarece: “A imitação era regra retórica e pedagógica por excelência, e não se confundia com plágio. O princípio normativo da imitação dos modelos foi admitido pacificamente pelos mestres da retórica heleno-romana, não como um processo inferior, mas como uma disciplina formadora através da qual se emulavam as virtudes dos grandes autores. [...] De imitação da natureza, concebida como o motor gerador
} 


\subsection{3) “Os Lusíadas nos pertence também um pouco":}

Joaquim Nabuco manteve silêncio frente a todos os ataques e críticas de alguns dos representantes da comunidade portuguesa residente no Rio de Janeiro, preferindo defender-se no próprio discurso. Palavras como estas, "Nesta festa uns são Brazileiros, outros Portuguezes, outros estrangeiros; temos todos porem o direito de abrigar-nos sob o manto do Poeta", ${ }^{269}$ conforme já observou Josué Montello, ${ }^{270}$ constituíram decerto resposta aos protestos dos doutores Figueiredo de Magalhães e Ferraz de Macedo. Era aquela, afinal, a melhor oportunidade de argumentar em favor de sua presença no evento na qualidade de orador oficial, decerto menos como Joaquim Nabuco do que como brasileiro. Isso não sem um toque da retórica modéstia: “[...] o Gabinete Portuguez commetteo a unica falta do seo brilhante programa, nomeando-me para fallar em seo nome." 271

Em História da crítica literária no Brasil, Wilson Martins contextualiza as comemorações do tricentenário de morte de Camões neste lado do Atlântico, em 1880, como uma "irônica coincidência" com um diagnóstico de literatos brasileiros, nessa época, de que "havíamos deixado 'definitivamente de lado a inteligência portuguesa". ${ }^{272}$ Tendo em vista ainda os ataques ao convite dirigido a Joaquim Nabuco, fica evidente o chão forrado de

\footnotetext{
das coisas, o espírito normativo dos romanos transformou o conceito em disciplina retórica de imitação de autores modelares, que, nos tempos modernos, se confundiram com os clássicos antigos, isto é, em vez de ir à natureza, imitavam-se os que já haviam, de modo excelente, imitado a natureza." (COUTINHO, 1968, p. 85-6)

${ }^{269}$ NABUCO, 1980, p.8. "Nesta festa uns são Brasileiros, outros Portugueses, outros estrangeiros. Temos todos, porém, o mesmo direito de abrigar-nos sob o manto do poeta" conforme NABUCO, 1949, p.3.

${ }_{270}$ Cf. MONTELLO, 1973, p.120-121.

${ }^{271}$ NABUCO, 1980, p.11. O trecho foi suprimido na versão de 1901.

272 MARTINS, 1983, p.216.
} 
melindres patrióticos (de brasileiros e portugueses) que o autor pernambucano estava pisando naquela data que, de fato, houve de "ser ouvida no outro seculo". 273

De qualquer modo, os contornos argumentativos do discurso que Nabuco proferiu já fogem à frente daquela polêmica em torno da autonomia da produção literária brasileira em relação à literatura portuguesa. Nelson H. Vieira comenta a celebração de 1880 no Brasil, de modo a esclarecer bem do que o pensamento nabucoano passa a conceber acerca de Camões, Brasil e Portugal:

Ocorrências, como a celebração em 1880 do Terceiro Centenário da morte de Camões, foram arquitectadas para elevar a cultura portuguesa perante os olhos dos brasileiros [...]. O Gabinete Português de Cultura, em diversas cidades brasileiras, realizou elaboradas festividades para a celebração do Centenário de Camões, no qual, brasileiros, como Joaquim Nabuco, voluntariamente participaram. Este acontecimento não foi porém LusoBrasilianismo, com seu desejo de unidade, ou seu conceito de comunidade. A celebração passou simplesmente como uma expressão de cooperação portuguesa e brasileira. ${ }^{274}$

Mas também é necessário saber que o evento de 1880, com participação ampla de uma nova geração de políticos e intelectuais críticos da estrutura do Segundo Reinado, era marcado por uma nova afirmação da identidade nacional. É sobre o que Angela Alonso discorre nesta passagem:

A raiz de ultramar, os laços com a cultura portuguesa foram reclamados como formadores da nacionalidade, suprimindo-se a distinção entre cultura autóctone e civilização européia. É o que embasa a demanda da geração 1870 pela integração do país no movimento "ocidental". ${ }^{275}$

\footnotetext{
273 NABUCO, 1980, p.30.

274 VIEIRA, 1991, p.74.

275 ALONSO, 2002, p.290.
} 
Seja como for, a situação com que o deputado pernambucano se deparava parecia, até certo ponto, refletir às avessas o que havia discutido na introdução a Camões e Os Lusídas. Em 1872, dirigira-se aos brasileiros, na defesa de um compatriota - ele mesmo - homenagear um autor da ex-metrópole. Em 1880, os parágrafos dedicados a responder à desaprovação e aos questionamentos relativos ao convite do Real Gabinete dirigem-se especialmente (embora de forma indireta) a esses portugueses contrariados e feridos no orgulho patriótico. Todavia, o pensamento e a argumentação nabucoanos entre os dois tricentenários tinham sensivelmente mudado no tocante ao assunto. Veremos adiante em quais aspectos.

Três linhas básicas orientam a argumentação do orador em defesa da legitimidade da participação dele, um brasileiro, naquelas comemorações de 1880: 1) o sentimento de pátria, impelido pelas ciências e pelas artes, seria destinado a estender-se para além das fronteiras nacionais, conciliando e enlaçando as nações; 2) a ligação histórica, cultural e linguística entre Portugal e Brasil; 3) os laços d'Os Lusíadas com este último país.

Tendo exercido cargos diplomáticos anos antes de se tornar deputado, Joaquim Nabuco mostrava-se bastante otimista diante de um contexto de recrudescimento dos nacionalismos e, por conseguinte, dos atritos internacionais, que, dali a algumas décadas, resultaria nas duas Grandes Guerras. Embora julgasse temerariamente admissíveis "muitas intolerancias" do fanatismo patriótico, Nabuco asseverava consistir numa contradição dessa postura o "recusarmos o concurso expontaneo das sympathias estrangeiras nas grandes expansões da nossa Patria". ${ }^{276}$ O movimento, então, estava no sentido de que "em toda a parte a sciencia prepara a unidade, emquanto a arte opera a união". ${ }^{277}$ No caso específico de Camões, estudado e admirado não apenas em Portugal, mas também no Brasil e em outros

\footnotetext{
${ }^{276}$ NABUCO, 1980, p.9. "muitas intolerancias" e "recusar-se o concurso es pontaneo da sympathia es trangei ra nas grandes expansões de cada povo" conforme NABUCO, 1949, p.3.

277 NABUCO, 1980, p.9. "em toda a parte a sciencia prepara a unidade, emquanto a arte opera a união" conforme NABUCO, 1949, p.3.
} 
países, indagava o deputado pernambucano: “[...] não paira a gloria do poeta acima das fronteiras dos Estados, ou estará o espirito humano tambem dividido em feudos inimigos?"278 Sob as bênçãos de Camões, cujos 300 anos de morte eram festejados naquele momento, Joaquim Nabuco assume por fim: "[...] nesta noite sou Portuguez", ${ }^{279}$ tomado por "um sentimento que, si não se confunde com o patriotismo, não deixa de confundir-se entretanto com o proprio orgulho nacional". ${ }^{280}$

Se entre as nações a tendência era a do congraçamento, porque "a patria é um sentimento que se alarga, abate as muralhas da China que o isolavam, e torna-se cada vez mais, como se tornou a familia entre os homens, e há de tornar-se a religião entre as Igrejas, um instrumento de paz, de conciliação, e de enlaçamento entre os povos", ${ }^{281}$ entre Portugal e Brasil a situação estaria ainda mais inserida nessas circunstâncias. Sobre o 10 de Junho de 1880, Nabuco lançava as perguntas: "Si o dia de hoje é o dia de Portugal, não é melhor para elle que a sua festa nacional seja considerada entre nós uma festa de familia? Si é o dia da lingoa Portugueza, não é esta tambem a que fallam dez milhões de Brazileiros?"282

Diversas seriam as razões que comprovariam a validade da participação de brasileiros naquela festa de caráter tão nacional ou mesmo nacionalista dos portugueses. Nabuco referese aos laços históricos, constituídos durante os séculos de relação metrópole-colônia, entre Portugal e Brasil; à permanência da dinastia de Bragança no governo imperial do território independente; à residência de vários portugueses em solo brasileiro, sendo, desse modo, “o

\footnotetext{
278 NABUCO, 1980, p.9. "não paira a gloria do poeta acima das fronteiras dos Estados, ou estará o espirito humano tambem dividido em feudos inimigos?" conforme NABUCO, 1949, p.3.

279 NABUCO, 1980, p.12. "nesta noite sou Portuguez" conforme NABUCO, 1949, p.6.

280 NABUCO, 1980, p.12. "um sentimento que, se não se confunde com o patriotismo, não deixa de confundirse, entretanto, com o proprio orgul ho nacional" conforme NABUCO, 1949, p.6.

${ }^{281}$ NABUCO, 1980, p.9. "a patria é um sentimento que se alarga, abate as muralhas que o isolavam, e se torna cada vez mais, como tornou-se a familia entre os homens e ha de tornar-se a religião entre as igrejas, um instrumento de paz, de conciliação e de enlaçamento entre os povos." conforme NABUCO, 1949, p.3.

282 NABUCO, 1980, p.9. "Se o dia de hoje é o dia de Portugal, não é melhor para este que a sua festa nacional seja considerada entre nós uma festa de familia? Se é o dia da lingua portugueza, não é esta, tambem, a que falam dez milhões de Brasileiros?" conforme NABUCO, 1949, p.3.
} 
Brazil a segunda patria dos Portuguezes". ${ }^{283}$ E, no que concerne à própria pessoa, o orador esclarece o motivo de ter aceitado o convite do Real Gabinete: “[...] aceitei este logar pela divida de gratidão que temos para com Portugal, e na qual, como Brazileiro, reclamo a minha quota parte". ${ }^{284}$ É a oportunidade de Joaquim Nabuco, já então reconhecido pelo engajamento na causa abolicionista, de pronunciar-se como quem "votou a sua vida politica toda á causa do trabalho livre". ${ }^{285}$ Cumpre informar que o autor pernambucano, no ensaio de 1872 , tocara no problema da escravidão no País, tendo inclusive recriminado Camões "um poeta tão recto", ao chamar "felicidade - a escravidão"286 de Nápoles, cativa dos espanhóis, em certa passagem d'Os Lusíadas. No discurso de 1880, em compensação, a lição camoniana é a oposta: a epopeia "fulmina a escravidão em dois versos, que encerram a eterna injustiça das grandes riquezas accumuladas pelo trabalho alheio não retribuido, quando promette não louvar a quem / 'Não acha que é justo e bom respeito / Que se pague o suor da servil gente"”. ${ }^{287}$ Mas dizíamos que o orador destaca (com tintas idealizadoras) a imigração portuguesa no Brasil, que fortalecia os vínculos entre ex-metrópole e ex-colônia, nestes termos: "O emigrante Portuguez chega ao Brazil sem fortuna, mas tambem sem vicios, e pelo seo trabalho crêa capitáes; vem só, e funda uma familia; seos filhos são Brazileiros; fallando a nossa lingoa, e da nossa raça, essa immigração nem parece de estrangeiros [...]."288

Por fim, a terceira linha argumentativa do discurso: quanto a Os Lusíadas, “[...] deixai-me dizel-o, elle nos pertence tambem um pouco", ${ }^{289}$ pois, à parte a comunhão estabelecida pela língua e pela ascendência, “[...] que nos faz tão bons herdeiros, pondo de

\footnotetext{
283 NABUCO, 1980, p.9. “o Brasil a segunda pátria dos portugueses”. Conforme NABUCO, 1949, p.5.

284 NABUCO, 1980, p.11. "acceitei este logar pela divida de gratidão que temos para com Portugal, e na qual, como Brasileiro, reclamo a minha parte" conforme NABUCO, 1949, p.5.

285 NABUCO, 1980, p.11. Trecho suprimido na versão de 1901.

${ }^{286}$ NABUCO, 1872, p.87.

287 NABUCO, 1980, p.27. "fulmina a escravidão em dois versos que encerram a eterna injustiça das grandes riquezas acumuladas pelo trabalho alheio não retribuído, quando promete não louvar a quem [...]" conforme NABUCO, 1949, p.22.

${ }^{288}$ NABUCO, 1980, p.11. Trecho suprimido na versão de 1901.

289 NABUCO, 1980, p.9. “deixai-me dizel-o, elle nos pertence tambem um pouco" conforme NABUCO, 1949, p.4.
} 
parte a tradição nacional, dos contemporaneos de Camões, e do velho Portugal dos Lusiadas, como os Portuguezes do século XIX", 290 "Qual é a idéa dos Lusiadas, si elles não são o poema das descobertas maritimas e da expansão territorial da raça portugueza? Mas o descobrimento do Brazil não será uma parte integrante desse conjuncto histórico?"291 E posto que a epopeia tematize, em sua centralidade, a navegação por mares nunca dantes navegados em direção às Índias, numa época como o século XIX, “[...] a India portugueza é uma pallida sombra do imperio que Affonso d'Albuquerque fundou, ao passo que o Brazil e os Lusiadas são as duas maiores obras de Portugal". ${ }^{292}$ Também o deputado pernambucano frisava a grande e crescente população de falantes da língua portuguesa no Brasil, esses leitores em potencial da obra camoniana.

Se, em Camões e Os Lusíadas, Joaquim Nabuco dizia que a epopeia camoniana era assunto nacional dos brasileiros, porque a produção literária nossa não estava independente da literatura portuguesa, no discurso de 1880 a afirmação é bem menos radical: "Os Lusiadas [...] elle nos pertence tambem um pouco". As razões para isso não mais seriam de ordem de autonomia/dependência literária, mas principalmente de tema (a obra refere-se ao Brasil, ao tematizar as grandes descobertas ultramarinas de Portugal) e de língua (o poema foi escrito em idioma falado no Brasil). Às razões - digamos - textuais somam-se as contextuais: se a epopeia era a bíblia da nacionalidade portuguesa, o Brasil, tendo um forte vínculo com Portugal, também teria direito a sentir um "orgulho nacional" pela importância universal de Camões. E, de fato, Joaquim Nabuco ressalta interrogativamente: "não paira a gloria do poeta acima das fronteiras dos Estados?" Assim pensando, o orador assume sentir-se português

\footnotetext{
${ }^{290}$ NABUCO, 1980, p.9. "que nos faz tão bons herdeiros dos contemporaneos de Camões, e do vel ho Portugal dos Lusiadas, como os Portuguezes do século XIX" conforme NABUCO, 1949, p.4.

${ }^{291}$ NABUCO, 1980, p.19. "Qual é a idéa dos Lusiadas, se elles não são o poema das descobertas maritimas e da expansão territorial da raça portugueza? O descobrimento do Brasil não fará parte desse conjunto histórico?" conforme NABUCO, 1949, p.4.

${ }^{292}$ NABUCO, 1980, p.19. "a India portugueza é uma pallida sombra do Imperio que Affonso d'Albuquerque fundou; a passo que o Brasil e os Lusíadas são as duas maiores obras de Portugal" conforme NABUCO, 1949, p.5.
} 
naquele 10 de Junho de 1880. Decerto devemos ter em mente aqui a afirmação da “continuidade cultural com a metrópole europeia", que Angela Alonso destaca como um dos propósitos das comemorações camonianas no Brasil.

O problema da escravidão aparece no discurso de 1880, mas sem atingir a questão propriamente literária, como havia ocorrido na introdução a Camões e Os Lusíadas. De qualquer forma, Nabuco levava ainda adiante o entendimento de que a independência brasileira apenas se completaria, caso tivesse fim o trabalho escravo no País. Mas a literatura, com efeito, não participava das preocupações abolicionistas do deputado pernambucano em seu primeiro mandato.

Fator ausente na introdução a Camões e Os Lusíadas, a língua compartilhada por portugueses e brasileiros surge como argumento para legitimar a participação do Brasil nas comemorações camonianas de 1880. E sendo no 10 de Junho festejado também o dia da língua portuguesa, e sendo esta falada por contingente bem mais numeroso aqui do que alémmar, Nabuco chega a termos persuasivos em sua argumentação.

Definitivamente, o Real Gabinete Português de Leitura do Rio de Janeiro encontrou em Joaquim Nabuco importante aliado na defesa do diálogo cultural entre brasileiros e portugueses, em conformidade com a razão de existir dessa mesma instituição. Seus dirigentes reconheceram tanto no deputado em primeiro mandato os méritos do ensaísta de Camões e Os Lusíadas, convidando-o para ser o orador oficial das comemorações camonianas, quanto no deputado em segundo mandato o valor de seu discurso proferido em 1880, voltando a convidá-lo para discursar, a 22 de dezembro de 1888, na inauguração da Biblioteca Portuguesa do Brasil. O discurso, também coligido no volume de 1901, intitula-se "Portugal e Brasil" e se desenvolve justamente em torno das relações entre os dois países, 
separados pela "lei da formação social da América", ${ }^{293}$ o que, no entanto, não teria quebrado "a aliança intelectual luso-brasileira", 294 representada na biblioteca que então se inaugurava. Todavia, Nabuco ia mais longe, ou era mais categórico, ao finalizar seu discurso, referindo-se ao Brasil como "uma nação que nunca deixou de ser portuguêsa", "um grande, um imenso Portugal americano", na medida em que "Portugal e Brasil formavam uma só nacionalidade tão certo como êles hão de sempre falar uma só língua". 295

É, de fato, a língua em comum o elemento no qual Joaquim Nabuco mais se concentra na afirmação da continuidade cultural entre ex-colônia e ex-metrópole, tão bem captada por Angela Alonso em suas reflexões acerca do tricentenário de morte de Camões comemorados no Brasil. Sendo um dever dos portugueses não "deixar morrer [sua] tradição na memória da nacionalidade que [eles fundaram]"296 na América, nada mais necessário do que disseminar "o culto de Camões":

Estamos aqui, senhores, no adro da religião camoniana no Brasil [o próprio Real Gabinete], e não preciso dizer-vos que essa é a base sólida e indestrutível de tôda a nossa literatura, pois ninguém que não admire Camões há de fazer, em nossa língua, nada que seja grande, fecundo, nada que mereça viver e reproduzir-se. Tudo o que sai da atração dos Lusíadas precipita-se pelos espaços vazios. Uma geração educada em Camões só pode ser uma geração forte, máscula, heróica. ${ }^{297}$

Portanto, num momento em que o grande abolicionista já estava vitorioso em sua grande causa, cuja reivindicação havia seis meses fora atendida, e por conta da qual deixara 
em plano secundário "todo o interesse que antes sentia pela poesia e pela arte", 298 era ainda a ocasião não de sustentar que as literaturas portuguesa e brasileira eram uma única, como o fizera em 1872, mas de continuar, como tinha feito em 1880, a defender a necessidade de um diálogo entre as duas literaturas, sob o patronato de Luíz Vaz de Camões. Em tal sentido é que o vate quinhentista pertenceria aos brasileiros, conforme pensava Nabuco nessa segunda etapa da demonstração pública de sua admiração pelo poeta d'Os Lusíadas.

${ }^{298}$ NABUCO, 1949, p.41. 


\section{CAPÍTULO 3:}

UM CAMÕES PAN-AMERICANISTA:

A RECEPÇÃO NABUCOANA EM 1908-09 


\section{1) Considerações preliminares:}

Quase três décadas transcorridas após ter pronunciado seu discurso de 1880, Joaquim Nabuco volta a tornar públicos sua admiração e seus conhecimentos acerca de Camões, em três datas distintas, em três diferentes universidades norte-americanas: a 14 de maio de 1908, na Yale University, pronuncia a conferência "The place of Camoens in literature"; a 21 de abril de 1909, no Vassar College, "Camoens, the lyric poet"; e dois dias depois, na Cornell University, "The Lusiads as epic of love". Mas em relação a 1880, as circunstâncias de 1908 e 1909 são completamente outras, no âmbito pessoal e contextual. Podemos começar por destacar que em 1872 tratava-se de um jovem ansioso por adentrar a celebridade pelas portas da política ou da literatura; oito anos depois, era o deputado em primeiro mandato, que empunhava a bandeira abolicionista; em sua última atuação camoniana, Nabuco é um senhor idoso, respeitado e reconhecido pelo histórico de lutas e de conquistas jurídicas, diplomáticas e políticas, sendo, havia desde alguns anos, embaixador do Brasil em Washington.

Naturalmente, entre 1880 e 1908-09, eventos de fundamental importância na vida de Nabuco e na história do País merecem menção mais detalhada e comentário prévio. Aliás, cumpre assinalar mais uma vez o fato de Joaquim Nabuco ter inserido seu discurso de 1880 em Escritos e discursos literários, volume no qual o autor coligira textos pronunciados e/ou publicados desde aquela data até momentos que precedem à publicação do livro, em 1901. Seu amplo leque temático - com páginas dedicadas a personagens brasileiros então recémfalecidos, ilustres uns, como Taunay e D. Pedro II, menos conhecidos outros, a personagens estrangeiros, como a rainha Vitória da Inglaterra, Ernest Renan, a eventos como a Revolução Farroupilha, e textos referentes à ABL, ao tricentenário de Anchieta e ao de Camões - talvez apenas se justifique como unidade, se o considerarmos em grande parte um painel-memorial 
dos tempos do Segundo Reinado, ato literário de um monarquista nostálgico em ostracismo político, depois do 15 de Novembro de 1889.

Aquele primeiro ano do século XX achava um Nabuco havia pouco tempo saído de seu exílio nas letras, a que o pernambucano se sentira compelido pela fidelidade à monarquia, uma vez proclamada a República. Com efeito, partilhando do pressentimento generalizado de que a abolição do regime escravocrata poderia conduzir à abolição do regime monárquico, Joaquim Nabuco muito lutou, como deputado em segundo mandato, pela reforma federalista no fito da manutenção da monarquia e, concomitantemente, atacava a ideia republicana em efervescência incontida no País. É que, conquanto observasse, a 15 de setembro de 1888, que "o partido republicano é uma força que ninguém pode mais destruir", ${ }^{299}$ dois meses e meio depois verificava:

[...] o atual movimento republicano é um puro efeito de causas acumuladas que nada têm de republicanas; é uma contra-revolução social, é a tentativa de restauração do escravismo pela servidão da gleba; é o despeito de uma classe, explorado e incensado, ao ponto de ameaçar a unidade moral e a integridade material da pátria. $^{300}$

A vingança escravista contra a monarquia que havia, na pessoa da princesa-regente Isabel, sancionado a abolição da escravatura seria, pois, segundo Nabuco, a grande razão para a articulação política que culminaria no 15 de Novembro. Ao contrário de muitos monarquistas, Joaquim Nabuco relutou por bastante tempo em aceitar convites para cargos públicos sob o novo regime, interessado este em arrebanhar antigas eminências políticas, no intuito de consolidar-se. Entre frágeis esperanças de restauração e as contundentes provas da barbárie jacobina que caracterizou os primeiros anos da república, Nabuco viu-se forçado a

\footnotetext{
${ }^{299}$ NABUCO in GOUVÊA, 1989, p.368.

${ }^{300}$ NABUCO in GOUVÊA, 1989, p.383-384.
} 
refugiar-se, por alguns períodos, na Europa, receoso das perseguições violentas que vitimavam monarquistas. Mas também, por outro lado, não se calou frente àquela desoladora paisagem política nacional. À semelhança do que, cerca de um século antes, fizera Tomás Antônio Gonzaga nas Cartas chilenas, o abolicionista pernambucano parecia manifestar suas críticas ao governo republicano, discutindo a história de um ditador chileno, que espelharia Floriano Peixoto, no que se tornou um dos principais títulos de sua opera omnia, o Balmaceda, publicado em 1895. De maneira mais direta, tinha publicado também em volume A intervenção estrangeira, em 1893, abordando o embate entre um ethos monárquico e o autoritarismo republicano na Revolta da Armada. Outro marco do manifesto nostálgico seu dos tempos de D. Pedro II são os anos nos quais se dedica a escrever Um estadista do império, obra titânica, de cunho historiográfico, que relatava a atuação política do senador Nabuco de Araújo, seu pai, num período feito grandioso, heroico mesmo, para servir de contraponto frente à degradação republicana. Era sua obra-prima, cujo primeiro volume sai em 1898. Só no ano seguinte, na presidência um civil, é que Nabuco aceitará cargo oferecido pelo novo regime, sendo convidado a advogar a defesa de territórios na Guiana, em contenda com a Inglaterra. Mesmo assim, não em atitude que conotaria, conforme sua própria vontade, em adesão à república, mas que simplesmente atestasse, acima de tudo, seu patriotismo.

A essa transformação drástica da ordem política no Brasil, que afetou profundamente a vida de Joaquim Nabuco, devemos acrescentar, como informação relevante, a sua reconversão ao catolicismo. Casado desde 1889 com Evelina Torres Soares Ribeiro, católica fervorosa, o agnóstico Nabuco, frente a tantas intempéries nacionais e pessoais (ostracismo político, perda de investimentos substanciosos na bolsa argentina, instabilidade profissional), foi-se a pouco e pouco, admirado do inabalável estoicismo da esposa, reaproximando da fé de que se afastara na juventude. Num dos períodos de exílio na Inglaterra, mais exatamente na igreja jesuíta de Farm Street, em Londres, esse processo de reconversão ao credo do Vaticano se inicia, para 
consolidar-se entre 1892 e 93, quando Nabuco escreve Foi voulue, obra apenas publicada postumamente, e ainda será como católico que dará a lume boa parte de suas reflexões filosofoides em Pensées détachées, de 1906. O fato é que o catolicismo do grande abolicionista reconverso, sem dúvida, enquadra-se numa fase da vida (a partir da década de 1890), em que, nas palavras de Angela Alonso, "seu tradicionalismo de origem desabrochou". ${ }^{301}$ Talvez fosse difícil ser diferente, tratando-se de um homem de quarentão para cinquentenário, a vivenciar mudanças tão radicais de um cenário político em que havia atuado desde a juventude. De qualquer modo, uma anotação no diário a 18 de janeiro de 1891 já sugere compreensão dos motivos que o levariam de volta à fé católica: “[...] não corresponderão as religiões às fases da vida mental do homem, o fetichismo à infância, o politeísmo à adolescência e mocidade, o Cristianismo à madureza, à razão humana verdadeira religião da Humanidade?"302

Ao aceitar tornar-se embaixador do Brasil em Washington, em 1904, Joaquim Nabuco definitivamente abraça o regime republicano, consolidado com seu terceiro presidente civil (Rodrigues Alves), e a doutrina do pan-americanismo monroísta. A ligação estreita entre um e outra na postura político-diplomática daquele ex-monarquista ficaria muito bem expressa no discurso "A república é incontestável", pronunciado no Rio de Janeiro, a 19 de julho de 1906. $\mathrm{Na}$ primeira parte desse texto, Nabuco dizia que, nas antigas discussões com Quintino Bocaiúva - aquele defendendo a monarquia; este, a república - o velho corifeu do movimento republicano brasileiro "acabou por ter razão, porque previu o curso dos acontecimentos e o verdadeiro desenlace da abolição". ${ }^{303} \mathrm{O}$ assunto da segunda parte do discurso, constituído de nítida unidade ideológica, é a causa em que o abolicionista depois de Maio de 1888 se engajaria: "Os destinos queriam que este resto de vida poupada da campanha da abolição

\footnotetext{
${ }^{301}$ ALONSO, 2007, p.233.

302 NABUCO, 2006, p.290.

${ }^{303}$ NABUCO, 1906, p.96.
} 
pudesse ser empregado em um serviço que enchesse na minha alma o vazio que aquela grande causa havia deixado. // Refiro-me à aproximação entre o Brasil e os Estados Unidos.”304

A adesão era uma mudança e tanto na vida de Nabuco. No século XIX, tendo viajado e trabalhado na Europa e nos Estados Unidos, estava convencido, como a maioria dos intelectuais brasileiros da época, que a civilização europeia, sobretudo inglesa e francesa, era o modelo em que o desenvolvimento brasileiro deveria se espelhar. Quanto às Terras do Tio Sam, em Minha formação, sentenciava:

É possível que a civilização americana venha um dia a ser mais grandiosa do que qualquer que o mundo conheceu, mas eu consideraria perigoso, por enquanto, renunciar a Europa nos Estados Unidos a tarefa de levar a cabo a obra da humanidade. [...] Os americanos, em grande escala, estão inventando a vida, como se nada existisse feito até hoje. Tudo isto sugere grandes inovações futuras, mas não existe ainda o menor sinal de que a elaboração do destino humano ou a revelação superior feita ao homem tenha um dia que passar para os Estados Unidos. A sua missão na história é ainda a mais absoluta incógnita. Se ele desaparecesse de repente, não se pode dizer o que é que a humanidade perderia de essencial, que raio se apagaria do espírito humano; não é ainda como se tivesse desaparecido a França, a Alemanha, a Inglaterra, a Itália, a Espanha. ${ }^{305}$

Todavia, no século $\mathrm{XX}$, receoso do recrudescimento de políticas imperialistas do Velho Continente e a decepção com o resultado na disputa com a Inglaterra por territórios da Guiana, em cuja defesa empregara mais do que prometia a força humana, Joaquim Nabuco passa a enxergar no estreitamento de laços com os Estados Unidos o caminho, em termos de política externa, mais conveniente para o Brasil. Na condição de embaixador em Washington, estavam unidos o útil e o agradável. Monroísta antes mesmo de assumir o cargo diplomático, o ilustre pernambucano apresentaria suas credenciais para um presidente norte-americano que

\footnotetext{
${ }^{304}$ NABUCO, 1906, p.98.

305 NABUCO, 1981, p.116.
} 
propalava a doutrina da América para os americanos. E sobre seu secretário, Elihu Root, dentre as breves palavras de um discurso pronunciado por ocasião de almoço em fevereiro de 1909, Nabuco definia elogiosamente: “[...] he read the Monroe Doctrine as a complete code of foreign policy; towards this Continent, solidarity; towards the rest of the world, good will and

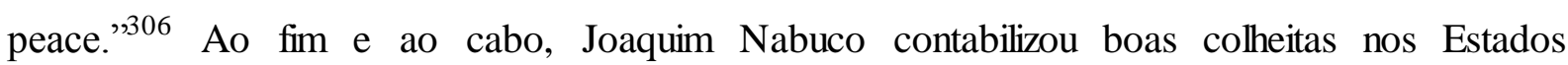
Unidos, no seu último lustro de existência: organizou e presidiu um fórum pan-americano realizado no Rio de Janeiro, em julho de 1906; conquistou a amizade ou, pelo menos, a simpatia do presidente Roosevelt e de Root; ${ }^{307}$ foi contemplado com título de doutor honoris causa por uma universidade norte-americana, conforme frisa Gilberto Freire, "talvez a primeira distinção dessa espécie recebida por brasileiro dos Estados Unidos". ${ }^{308}$

$\mathrm{Na}$ mesma altura em que o personagem-narrador de seu amigo Machado de Assis tentava, em Dom Casmurro, "atar as duas pontas da vida, e restaurar na velhice a adolescência", ${ }^{309}$ Joaquim Nabuco parecia reproduzir o procedimento, decerto de modo menos voluntário que Bentinho. Antes a dedicação à literatura, logo depois de Novembro de 1889, é verdade que forçada pela conjuntura política nacional, resultando em títulos como Um estadista do império e Minha formação, seria o revival de entre 1873 e 1879, anos que constituiriam, nas palavras do próprio Nabuco, "meu período literário". 310 E ainda, conforme destaca Marco Aurélio Nogueira: “[...] na distante juventude estavam os ideias republicanos, a primeira experiência diplomática [...] e a empolgação cosmopolita [...]. Sob certo aspecto,

\footnotetext{
306 NABUCO, 1909, p.2. Tradução nossa: "ele compreende a doutrina Monroe como um completo código de política externa: em relação a este Continente, solidariedade; em relação ao resto do mundo, boa vontade e paz."

307 Anotação no diário de Nabuco, em 26 de outubro de 1907: "Barrett hoje disse-me ter ouvido de Mr. Root que eu era de quantos homens ele tem visto o que melhor realiza a sua idéia de embaixador. Disse isto a um senador à vista dele. Satisfaz-me essa lisonjeira opinião a meu respeito, de um homem que é, sobretudo, meu amigo." (NABUCO, 2006, p.654)

${ }^{308}$ FREIRE in NABUCO, 1981, p.16.

309 ASSIS, 1997, p.3.

310 NABUCO, 1981, p.57.
} 
voltava às origens. ${ }^{\text {311 }}$ Machado de Assis publicava Dom Casmurro em 1899; nesse mesmo ano, o grande pernambucano dava o primeiro passo rumo à aproximação com os republicanos.

Foi na condição de embaixador do Brasil em Washington, desde 1905, que Joaquim Nabuco proferiu 18 conferências, algumas a convite de instituições universitárias norteamericanas. Três dessas conferências dedicam-se a Camões ("The place of Camoens in literature", "Camoens, the lyric poet" e "The Lusiads as epic of love"), tendo Nabuco planejado e esboçado uma quarta, que as condições ruins de saúde, que não tardariam a leválo à morte, impedi-lo-iam de proferi-la e mesmo redigi-la.

Vimos no capítulo anterior deste trabalho que Joaquim Nabuco não perdera a oportunidade de, escrevendo e discursando sobre Camões, em 1872 e 1880, trazer à baila a questão da escravidão brasileira. Devemos ter em mente que a plataforma abolicionista não interferira no ensaio e no discurso sobre o quinhentista português tanto quanto o panamericanismo o fará nessas conferências. É curiosa e expressiva a informação de que Nabuco, frente ao telegrama no qual Rio Branco, ministro das Relações Exteriores, o convidava (ou invectivava) ao cargo de embaixador, que o faria sair de Londres para morar na capital norteamericana, desabafa ao amigo Graça Aranha: “[...] em diversos casos as maiores obras (veja o Lusíadas), resultaram muitas vezes de remoções forçadas [...] quando digo remoção forçada não quero dizer que o Paranhos não me tivesse deixado a opção material, não me deixou porém a moral, ou patriótica." ${ }^{312}$ Mas antes de discutirmos a relação entre pan-americanismo monroísta e as três conferências camonianas de Joaquim Nabuco, procedamos a uma visada

\footnotetext{
${ }^{311}$ NOGUEIRA, 2010, p.255.

312 Nota de PEREIRA, 2006, p.29.
} 
conjunta desses textos, recorrendo ao original e à tradução que deles realizou Carolina Nabuco. $^{313}$

\section{2) O que propõem as conferências:}

Tudo pareceu começar com uma carta remetida ao professor Henry R. Lang da Yale University, que the dava de volta "a sugestão [...] de ir fazer umas conferências em Yale sobre o lugar dele [do quinhentista português] entre os maiores poetas". ${ }^{314}$ Eis o que está registrado no diário de Joaquim Nabuco, a 30 de janeiro de 1908. Dois dias antes, outra anotação comprova como o velho abolicionista respirava ares camonianos no período: "Ontem e hoje faço diversos sonetos a Camões, que vou mandar com os do Centenário ao Carvalho Monteiro para a sua coleção". 315 Dali a dois meses, como o próprio embaixador assumiria desde a primeira conferência, teria a oportunidade de se tornar, em terra estrangeira, o rapsodo de Camões.

Se, no tocante à adesão à república, Nabuco parecia atar as duas pontas de sua própria vida, com as conferências proferidas nos EUA algo similar se sucedia. Leiamos o primeiro parágrafo de "The place of Camoens in literature", a primeira das conferências camonianas que o embaixador pronuncia, a 14 de maio de 1908:

\footnotetext{
${ }^{313}$ Consultamos Camões e assumptos americanos. São Paulo: Companhia Editora Nacional; Rio de Janeiro: Civilização Brasileira, 1940. Julgamos conveniente atualizar a ortografia dessa edição.

${ }^{314}$ NABUCO, 2006, p.665.

${ }^{315}$ NABUCO, 2006, p.665. Infelizmente, não tivemos acesso a tais poemas, destinados, conforme vontade do autor, a "ficarem inéditos na biblioteca [de Carvalho Monteiro]". (NABUCO, 2006, p.665) Na verdade, tampouco obtivemos a notícia de publicação posterior deles. Seria contribuição valiosa como termo comparativo ao que se dera em 1880, quando Joaquim Nabuco discursou e poetou acerca de Camões.
} 
When I had read the Lusiads for the first time, I at once wrote a book to tell of my wonder, offering for it the only apology that a tribute of love is always acceptable to a poet. I do not repent of having recorded in print that early impression, which has developed into years of faithful admiration and has kept company with my mind throughout life. Still I always intended to renew to Camoens on my decline the vow of my youth, and it is quite an unexpected fortune for me to be allowed to do it before a great American University. $^{316}$

Obviamente o conferencista referia-se a Camões e Os Lusíadas, o ensaio que tinha publicado 36 anos antes e que, verdade seja dita, nunca deixou de assombrar as atividades camonianos de Nabuco. Afinal, o convite que recebera do Gabinete Português de Leitura, para ser o orador oficial das comemorações do tricentenário de morte do poeta quinhentista, realizadas no Rio de Janeiro, era motivado e justificado pela publicação desse seu trabalho de 1872.

Provavelmente sem tê-lo planejado, Nabuco acabou, com a sequência de suas três conferências camonianas pronunciadas nos Estados Unidos, por articular, de maneira interessante, a abordagem do épico e do lírico na obra do quinhentista português. Se "The place of Camoens in literature" focaliza Os Lusíadas e "Camoens, the lyric poet" sonetos e canções, a última dessas conferências parece sintetizar a temática das anteriores na fórmula “The Lusiads as epic of love". Esse título, aliás, resgata compreensão acerca da epopeia como “o poema de Vênus”, exposta em 1872. E essa expressão - “o poema de Vênus” - reaparece, pelo menos, nas duas primeiras conferências. Em Camões e Os Lusíadas, o jovem autor pernambucano assim definia a grande obra da literatura portuguesa, destacando o papel da deusa no sucesso da viagem capitaneada por Vasco da Gama, episódio que resumia em si toda

\footnotetext{
${ }^{316}$ NABUCO(a), 1924, p.1. Tradução: “Depois de ler, pela primeira vez, os Lusíadas não demorei em externar o meu deslumbramento em um pequeno volume, trabalho de mocidade para o qual não ofereci outra desculpa senão a de que todo tributo de amor deve ser aceitável a um poeta. Não me arrependo de ter assim registrado minha primeira impressão, que cresceu sempre em anos de culto fiel, e acompanhou o meu espírito através da vida inteira. Sempre, porém, tive a intenção de renovar a Camões, antes de morrer, a homenagem que lhe prestei na mocidade. Feliz é o ensejo que se me apresenta agora de desempenhar-me deste voto perante uma grande Universidade americana." (NABUCO, 1940, p.1)
} 
a história heroica de Portugal. $\mathrm{O}$ amor teria impelido e protegido os portugueses que navegavam rumo às Índias, de tal modo que Nabuco em 1872 ensinava que, "se os Lusiadas fossem uma obra religiosa, seriam o poema de Venus". ${ }^{317}$ Em "The place of Camoens in literature", retomando essa reflexão da juventude, o então embaixador do Brasil em Washington vinha a dizer: "The Lusiads is truly the poem of Venus. It is a censer, in which are burnt to her all the perfumes of the newly discovered East". 318 Já em "Camoens, the lyric poet" afirmava prestar o quinhentista português verdadeiro "worship of woman"319 e ser o amor "the daily Bread of his genius; as a poet, he fed on love: in his early verses, as the singer of his own joys and pains; in his maturity, as the mirror of its power on nature and mankind". ${ }^{320}$ Desse modo, tanto o Camões predominantemente lírico na juventude quanto o marcadamente épico na maturidade eram poetas que se inspiravam no amor. Próximo de concluir essa sua segunda conferência, Joaquim Nabuco dizia:

Were love to be banished from life, from literature and from art, the Lusiads, like the Iliad, and the Odyssey, and the Bible, would cease to count for mankind; but however supremely love might be purified by Religion and moral dignity, the Lusiads would keep intact its heat and its light. You will find in its poetry the soul of the Renaissance purified by the breath of Chivalry. It is the poem of heroism as well as that of love; the poem of Neptune as the poem of Venus; that is, it represents the combined power of the two poles of mankind: the masculine and the feminine. ${ }^{321}$

\footnotetext{
${ }^{317}$ NABUCO, 1872, p.207.

318 NABUCO(a), 1924, p.17. Tradução: “Os Lusíadas são de fato o poema de Vênus. São o turíbulo em que se queimam em sua honra todos os perfumes do recém-descoberto Oriente." (NABUCO, 1940, p.19)

${ }^{319}$ NABUCO(b), 1924, p.1. Tradução: "culto da mulher" (NABUCO, 1940, p.33)

320 NABUCO(b), 1924, p.1. Tradução: “o pão quotidiano do seu gênio. Alimentou -se [Camões] sempre de amor, como poeta. Jovem, no cantar das próprias penas e alegrias, e, na idade madura, fazendo-se o espel ho de seu poder sobre a natureza e a humanidade." (NABUCO, 1940, p.33)

${ }^{321}$ NABUCO(b), 1924, p.28. Tradução: "Se o amor fosse abolido, da vida, da literatura e da arte, então os Lusíadas e,com estes, a llíada, a Odisseia e a Bíblia, deixariam de contar para a humanidade; mas, por muito que a Religião e a dignidade moral purifiquem o amor, ele guardará nos Lusíadas seu calor e sua luz. No Poema de Camões, encontrareis a alma da Renascença, purificada pelo hálito dos seus cavaleiros. É o poema do heroísmo, tanto quanto do amor; de Netuno, tanto quanto de Vênus; é o poema, portanto, que representa o poder reunido dos dois polos da Humanidade: o masculino e o feminino." (NABUCO, 1940, p.65)
} 
O amor, personificado pela deusa Vênus, também estaria ao lado, em importância, n'Os Lusíadas, do patriotismo, com este formando "two parallel chains". ${ }^{322}$ A corrente patriótica representar-se-ia em "the Invocation to Dom Sebastian, the battle of Ourique, the battle of Aljubarrota, Dom Manoel's dream, the departure of Vasco da Gama from Belem, the doubling of the Cape of Good Hope";,323 a corrente amorosa, por sua vez, em "Venus before Jupiter in the first Canto, Ignez de Castro in the third, Adamastor in the fifth, the forge of Cupid and the Isle of Love in the ninth". ${ }^{324}$ É o que explica Nabuco em "The Lusiads as epic of love", conferência na qual o embaixador brasileiro enlaça vida e obra e vai apontando como o sentimento do amor marcou Camões, a começar pela suposta origem etimológica de seu nobre sobrenome e pela influência que exerceu nas desventuras sofridas e na glória gozada pelo poeta. Sendo assim, Joaquim Nabuco assevera: "Poetry for Camoens, if not limited to love, was always convertible into love, at it higher power."325 Também a participação de Vênus na epopeia daria a entender que o amor consistiria na "dominant force of the universe". ${ }^{326}$ Cumpre observar como o conferencista não se atém a acentuar a imagem amedrontadora do monstro Adamastor, personificação do Cabo das Tormentas e das "relentles forces that opposed the advance of man on sea": 327 trata-se - o personagem - da expressão do "tenderest heart that any lover ever had". 328

Seja como for, Joaquim Nabuco persevera - como a maioria de seus contemporâneos e predecessores - na valorização maior da épica camoniana frente à lírica. Para fundamentar

\footnotetext{
322 NABUCO(b), 1924, p.8. Tradução: "duas cordilheiras paralelas" (NABUCO, 1940, p.79)

${ }^{323}$ NABUCO(b), 1924, p.8. Tradução: "A invocação a Dom Sebastião; a batalha de Ourique; a de Aljubarrota; o sonho de Dom Manuel; a partida de Vasco da Gama, de Belém; a passagem do Cabo da Boa Esperança" (NABUCO, 1940, p.79)

324 NABUCO(b), 1924, p.8. Tradução: "Vênus perante Júpiter, no primeiro Canto, Inês de Castro, no terceiro, Adamastor no quinto, a Forja de Cupido e a Il ha dos Amores no nono." (NABUCO, 1940, p.79)

${ }^{325}$ NABUCO(b), 1924, p.14. Tradução: "A poesia de Camões, embora não se limitasse ao amor, era sempre conversível em amor da mais alta tensão." (NABUCO, 1940, p.87)

${ }^{326} \mathrm{NABUCO}(\mathrm{b}), 1924$, p.9. Tradução: "força dominante do Universo". (NABUCO, 1940, p.80)

327 NABUCO(b), 1924, p.13. Tradução: "forças cegas e impiedosas que tolhem o progresso do homem sobre o mar". (NABUCO, 1940, p.87)

${ }^{328}$ NABUCO(b), 1924, p.13. Tradução: “coração mais terno que jamais a mante teve". (NABUCO, 1940, p.87)
} 
essa apreciação, defende que "the epic, or collective, light is more powerful of its nature than the lyric, or personal, one". ${ }^{329}$ Tão convicto o embaixador estava disso que via prejudicado o lugar de Camões na literatura universal, caso não houvesse escrito Os Lusíadas; seu nome, "owing to the narrower circle of Portuguese, would not compete with Petrarca, and I am afraid that he would not even be recognized in Portugal and Brazil as infinitely above all other native poets". ${ }^{330}$ Mas ao deter-se propriamente na poesia lírica camoniana, Nabuco revela duas preocupações básicas: esclarecer o tratamento da temática amorosa e situar o autor renascentista como herdeiro direto da lírica dantesca e petrarquiana. Citados alguns sonetos na íntegra e longas passagens de duas canções, na segunda conferência, a conclusão aparentemente contraditória - é que Camões "really deserves to be counted among the greatest lyric poets". 331

Lembremo-nos de que Nabuco, em 1872, assinalava o fato de poucos brasileiros lerem Os Lusíadas ("[...] é triste dizêl-o, os Lusiadas são um livro pouco lido e pouco conhecido" ${ }^{332}$ ), à leitura desse clássico preferindo grande parte dos leitores do País a da literatura romântica francesa ou escrita sob ressonância do modelo romântico francês (literatura essa que fala "ao sistema nervoso, á sensibilidade doentia das mulheres hystericas e aos homens ociosos"333). Também no discurso de 1880, o então deputado pernambucano requeria a distribuição de exemplares da epopeia camoniana nas escolas do País. Naturalmente, numa outra conjuntura, Joaquim Nabuco, no século XX, diagnostica a mesma necessidade de converter os jovens estudantes universitários norte-americanos, inseridos

\footnotetext{
${ }^{329}$ NABUCO(b), 1924, p.6. Tradução: “a luz coletiva, ou épica, é por sua natureza mais poderosa que a lírica, ou pessoal" (NABUCO, 1940, p.39)

${ }^{330}$ NABUCO(b), 1924, p.7. Tradução: "dada a repercussão menor do idioma português, a fama de Camões sem os Lusíadas não poderia competir com a de Petrarca. Receio que seu nome, mesmo em Portugal e no Brasil, não estivesse tão infinitamente acima dos outros poetas pátrios." (NABUCO, 1940, p.39)

331 NABUCO(b), 1924, p.26. Tradução: "realmente merece ser contado entre os maiores poetas líricos". (NABUCO, 1940, p.63-64)

332 NABUCO, 1872, p.7.

${ }^{333}$ NABUCO, 1872, p.8.
} 
numa cultura hegemônica no cenário mundial, em leitores de Camões, autor esse pertencente aos quadros da cultura latina, em declínio. O cerne da discussão inicial de "The place of Camoens in literature" revela-se ser como traduzir Os Lusíadas para o inglês, de modo a manter ao máximo a expressividade poética do original. Nabuco afirma que as traduções disponíveis, antigas e mais recentes, não o satisfazem e incentiva uma nova, a cargo do professor Henry Lang, presente no momento em que proferiria o embaixador brasileiro. Essa tradução haveria de ser em prosa (pois "Translations in verse [...] generaly associate also two very unequal poets" ${ }^{\text {334 }}$ ) e levaria em conta as melhores soluções encontradas por outros tradutores.

Ainda refletindo sobre o problema de se traduzir Os Lusíadas para o inglês, na terceira conferência camoniana pronunciada nos EUA, Nabuco postula que "the essence of poetry is thought, not sound, which is only a vehicle for it". ${ }^{335}$ Donde, mesmo que traduzidas, obras como a Bíblia e a Ilíada ainda assim teriam estatuto de opera magna "in whatever language they may be translated". ${ }^{336}$ De todo modo, o conferencista salienta: "The original verse, in the poet's own language, has a direct grasp upon the memory and makes mind resound with it throughout life, while the prose translation does not interest the auditive, the musical mechanism of mind."337 Parece que esse incontornável obstáculo de acesso à epopeia camoniana a um público não conhecedor da língua portuguesa está de mãos dadas com a profunda ligação entre os falantes desse idioma e o poeta quinhentista. Com efeito, segundo Nabuco: "The Portuguese language will always be called 'the language of Camoens', while

\footnotetext{
${ }^{334}$ NABUCO(b), 1924, p.8. Tradução: "Traduções em verso [...] tem a mais [o inconveniente] de associar em geral dois poetas desiguais" (NABUCO, 1940, p.41)

${ }^{335}$ NABUCO(c), 1924, p.1. Tradução: “a essência da poesia não está no som, mas no pensamento, do qual o som é apenas o veículo" (NABUCO, 1940, p.71)

${ }^{336}$ NABUCO(c), 1924, p.8. Tradução: "as maiores obras das línguas em que foram traduzidas" (NABUCO, 1940, p.71)

${ }^{337}$ NABUCO(c), 1924, p.1. Tradução: "O verso original, na língua do poeta, tem acesso direto à memória, criando no espírito ressonâncias que perduram por toda a vida, enquanto a tradução em prosa não consegue interessar o mecanismo auditivo ou musical do cérebro" (NABUCO, 1940, p.71)
} 
no poet in the world has more the devotion of his own people, nay, of all who speak his language, than he.”338 De todos? Não exageraria o embaixador brasileiro, que havia décadas reclamava dos poucos leitores de Camões no Brasil? ${ }^{339}$ De certo não teria aumentado tão significativamente o número de brasileiros que leriam Os Lusíadas. Cabe aqui observar, todavia, que o conferencista não fala em leitura, mas em devoção, expressa nas comemorações de 1880 realizadas pelo Gabinete Português de Leitura do Rio de Janeiro, com o apoio do parlamento nacional, e as realizadas em Portugal.

Dentro dessa mesma questão considerada acima, temos o conflito (ou contradição) entre a segurança do lugar de Camões na literatura - lugar que seria em meio aos maiores poetas de todos os tempos - e os tempos difíceis para os clássicos, resultado do ocaso da "Latin influence" 340 e da ascensão da hegemonia cultural anglo-germânica. Como se resolve isso? Joaquim Nabuco parece aqui pensar em duas esferas distintas: a) a dos estudiosos e críticos ocidentais, incluídos ingleses, alemães e norte-americanos, que se dedicavam a zelar pela importância universal da poesia camoniana; e b) a dos leitores comuns, em especial os não falantes da língua portuguesa, que dificilmente entrariam em contato com a obra de Camões, em vista das inevitáveis perdas de expressividade poética nas traduções e da nova conjuntura, mais favorável à divulgação de autores anglo-germânicos. Mas também o embaixador brasileiro chegava ao ponto de asseverar, nos diletos termos metafóricos:

When I see his great Poem so completely ignored as it is in foreign countries, I do not grieve for him. What does it matter to Antares, or to

\footnotetext{
${ }^{338}$ NABUCO(c), 1924, p.22. Tradução: “A língua portuguesa será sempre chamada a língua de Camões, nem há poeta no mundo que possua como ele a devoção de todo seu povo, digo mais, de todos que Ihe falam a língua" (NABUCO, 1940, p.97)

${ }^{339}$ Convém, a esse propósito, citar passagem do discurso de inauguração da Biblioteca Portuguesa do Brasil, texto que discutimos na última seção do capítulo anterior desta monografia: "Não há um brasileiro talvez, que tenha pensado meia hora seguida sôbre coisas portuguêsas. Nós [brasileiros] falamos a mesma língua, mas de que serve, se não lemos o português?" (NABUCO, 1949, p.44)

${ }^{340} \operatorname{NABUCO}(\mathrm{a}), 1924, \mathrm{p} .1$.
} 
Sirius, if they are not seen in all their grandeur by all men? A few telescopes turned on them suffice to their glory in our little planet. ${ }^{341}$

Com isso, Nabuco procurava disseminar a palavra camoniana, não receoso da sobrevivência desta, numa época em que a cultura anglo-germânica sobrepujava a latina, mas sim preocupado com a perda dos próprios leitores e estudantes que desconheciam um dos maiores valores literários do Ocidente - Camões. Porém, o ex-deputado pernambucano discernia a leitura dos grandes clássicos da leitura de grande parte da literatura da época:

One had better not touch Homer, or Dante, or Camoens, if one has contracted the habit of reading to kill time. To enjoy their company we need the contrary habit of reading to treasure up our passing hours in undying recollections. To read the great authors of the past is a duty for all who are real particles of the human intelligence. If one lets his taste for the writings of the day absorb him, he overlooks that sacred duty of watching over the precious deposits of the human mind, of keeping fresh and retentive the memory of our race, of increasiag its touch with the past the more it drifts away from us. ${ }^{342}$

No contexto dessas conferências, Joaquim Nabuco é um homem do século XIX, falando no século XX. Contando 60 anos, reconvertido ao catolicismo e, segundo alguns biógrafos, mais afeito ao conservadorismo (algo, afinal, comum e esperável para a idade), o embaixador brasileiro tece comentários sobre a nova conjuntura que se abria ou se consolidava na jovem centúria. Especialmente em "The Lusiads as epic of love", temos a

\footnotetext{
${ }^{341}$ NABUCO(c), 1924, p.22. Tradução: "Quando vejo seu grande poema tão completamente desconhecido de outros povos, não o lamento por causa de Camões. Que importa a Antares ou a Sírius não serem vistos em toda sua grandeza por todos os homens? Alguns telescópios virados sobre eles bastam para sua glória no nosso planeta". (NABUCO, 1940, p.97)

${ }_{342}$ NABUCO(b), 1924, p.26-27. Tradução: "Quem contraiu o hábito de ler para matar tempo não se deve aproximar de Homero, de Dante ou de Camões, porque para gozar sua companhia, é preciso, pelo contrário, o hábito de acumular nas horas passadas em leitura, recordações inapagáveis. Conhecer os grandes autores do passado é um dever para todos os que de fato querem ser parcelas da inteligência humana. Qu em se deixar absorver pelos escritos da própria época, falta aos deveres sagrados de velar sobre os depósitos preciosos do espírito humano, conservar a frescura retentiva da memória de nossa raça, aumentar nosso contato com o passado à medida que este se vai afastando." (NABUCO, 1940, p.64)
} 
contraposição antitética do gênio, sofredor e criador, no passado, e a condição profissional de muitos dos escritores contemporâneos, entendendo-se haver "a very high conscience",343 a "stop a dealer on the way to fortune from taking advantage of the public favor and from watering his inspiration". ${ }^{344}$ Seja como for, "the cycle of Literature seems to be already closed, the goal of the human ideal having been attained in it, as well as in Painting, Sculpture, Architecture, Music and Religion", ${ }^{345}$ perspectiva e diagnóstico que não escondem seu caráter hegeliano. O último parágrafo da conferência é em tom elegíaco que registra: "There is now about forty years that I follow the march of literature, and its relative place in the world seems to me to become each day smaller."346 A invenção da máquina-de-escrever decretara a morte do manuscrito, promovendo a nova e lamentável situação de "the affinities of inspiration with the machine"347 muito certamente não serem "the same as with the pen". ${ }^{348}$ Embora a imortalidade dos grandes artistas estivesse segura, Nabuco elenca apenas exemplos de muito antes de seu tempo - Homero, Dante, Camões e Shakespeare -, sugerindo assim que, de fato, a era da arte já havia terminado.

A visão sobre literatura e as artes em geral nesse período em que professava as conferências camonianas nos EUA é sensivelmente insatisfeita com a contemporaneidade e nostálgica ou aferrada aos valores clássicos. A falta de sintonia com essa época pode ser averiguada, tendo-se em vista que em fevereiro de 1909 Marinetti publicava o "Manifesto do futurismo", proposta de inovação revolucionária estética que, aliás, entusiasmaria o jovem Graça Aranha, com quem Nabuco tinha então laços de amizade, não obstante a diferença

\footnotetext{
343 NABUCO(c), 1924, p.6. Tradução: "uma consciência muito alta" (NABUCO, 1940, p.76)

344 NABUCO(c), 1924, p.6. Tradução: "impedir que o mercenário em busca da fortuna tire proveito do favor do público e acrescente água à sua inspiração" (NABUCO, 1940, p.76)

${ }^{345}$ NABUCO(c), 1924, p.6. Tradução: "o ciclo da Literatura parece já estar fechado, tendo ela atingido, como a Pintura, a Escultura, a Arquitetura, a Música e a Religião, a mira final do ideal humano" (NABUCO, 1940, p.77)

${ }^{346}$ NABUCO(c), 1924, p.23. Tradução: “Há agora uns quarenta a nos que acompanho a marcha da litera tura, e, a cada dia, seu lugar relativo neste mundo me parece menor." (NABUCO, 1940, p.98)

347 NABUCO, 1924, p.23. Tradução: "as afinidades de ins piração com a máquina" (NABUCO, 1940, p.98)

348 NABUCO, 1924, p.23. Tradução: "as mesmas com as da pena" (NABUCO, 1940, p.98)
} 
etária considerável entre os dois. Entretanto, seria exigir demais de um sexagenário, desde a juventude admirador do legado dos classicismos, render-se ao gosto vanguardista que irrompia no século XX. Afinal, Nabuco era um homem oitocentista, e, ao lado de um Machado de Assis, mal ou não tiveram olhos mesmo para a poesia de Baudelaire, de Rimbaud, de Mallarmé. Em certa medida, as três conferências endossavam o diagnóstico do fim da arte e nelas o autor pernambucano se confessava incomodado com o ambiente mercadológico no qual a arte se envolvia, já desde o século retrasado, a exemplo do que analisaria Walter Benjamin sobre o poeta das Flores do mal. ${ }^{349}$

Vimos que, no tocante à tradução, para Nabuco, a ideia de uma autoria individual perde a importância em favor da qualidade do texto. Todavia, vale recordar que Nabuco compreendia, àquela altura, Os Lusíadas como poema passível de ser ampliado com outros episódios heroicos da história de Portugal, desde que houvesse poeta de nível comparável a Camões. Dá-se aqui, portanto, mudança drástica de concepção e avaliação da estrutura da obra. Na conferência de 1880, Joaquim Nabuco retomava, mais severamente, a crítica feita em 1872 aos cantos posteriores ao sexto da epopeia, nos quais enxergava, à exceção do episódio da Ilha dos Amores, o cansaço do poeta e, por fim, uma expansão forçada, talvez sucedida porque o autor acreditasse que uma grande obra deveria ser uma obra grande. Nessa conferência de 1908, Nabuco passa a considerar Os Lusíadas obra em aberto, na medida em que "Vasco da Gama's voyage is only the episode of the Poem". ${ }^{350}$

Por outro lado, devemos observar que essa abertura do poema, segundo o embaixador, refere-se ao ciclo da narrativa da história de Portugal, que os cantos sétimo, oitavo, novo e décimo não tematizam. A possibilidade de acréscimo de outras páginas à obra dar-se-ia entre os cantos sexto e sétimo.

\footnotetext{
${ }^{349}$ Está claro que nos referimos ao ensaio Charles Baudelaire: um lírico no auge do capitalismo.

350 NABUCO(a), 1924, p.6. Tradução: "A viagem de Vasco da Gama não é senão um episódio do poema". (NABUCO, 1940, p.6)
} 
É também pensando assim que o conferencista defende Camões dos que recriminam sua epopeia por conter muito da Eneida. Afinal, Nabuco cita a frase de Molière, "Je prends mon bien où je le trouve", sendo essa "law of genius", ${ }^{351}$ que deve "make it truly his own by a different and superior title". ${ }^{352}$ Com efeito, ao cotejar o trabalho de 1872 e "The place of Camoens in literature", mudanças significativas se fazem notar no que se refere à presença dos intertextos na obra do quinhentista português. No terceiro capítulo do segundo livro de Camões e os Lusíadas, o jovem autor, em linguagem condoreira, mostrava-se desconfortável frente às passagens nas quais a Eneida se revelaria o modelo para a epopeia publicada em 1572:

O canto II dos Lusiadas resente-se da leitura da Eneida; o poeta ainda tinha diante de si, como modelo, o poema de Virgilio, precisava ainda de um guia, não tendo coragem para fazer acceitar as creações do seu génio. Seguindo, porém, o original latino, Camões mostrou sempre que imital-o era mais um constrangimento do que um auxilio para si. É elle como um condor que, posto nos Alpes e desconfiando do poder de seu vôo, não deixasse a região das águias. ${ }^{353}$

Esse julgamento, inseguro, comprometido pelo comentário posterior "reconhece-se que o que elle [Camões] produz é distincto, original, novo, como uma creação"354 e, mais adiante, "o poeta, a nosso ver, não tentou o que podia: ser original, seguindo Virgilio"355 converte-se, na conferência de 1908, em concepção mais amadurecida e convicta sobre o gênio em geral e o camoniano em particular.

\footnotetext{
${ }^{351}$ NABUCO(a), 1924, p.25. Tradução: "lei do gênio" (NABUCO, 1940, p.29).

${ }^{352}$ NABUCO(a), 1924, p.25. Tradução: "firmar o direito de posse com um título diferente e superior". (NABUCO, 1940, p.29).

${ }^{353}$ NABUCO, 1872, p.180.

${ }^{354}$ NABUCO, 1872, p.180.

${ }^{355}$ NABUCO, 1872, p.190.
} 
Outra questão importante contemplada nessas três conferências refere-se à crítica literária e à recepção de Camões no século XIX. Em "Camoens, the lyric poet", embora não deixe de reverenciar o resultado das pesquisas e interpretações de cunho biográfico de Teófilo Braga e Wilhelm Storck - os dois principais nomes aqui lembrados -, Joaquim Nabuco pontua diversas restrições em relação a "their divining gift" ${ }^{\text {"35 }}$ que conduziram o português e o alemão a extrair certezas acerca de datas e episódios da vida de Camões, com base em poemas. Também o conferencista reprova o fetichismo de Stork, Teófilo Braga, Richard Burton, e outros, fetichismo que os obrigaria a ver somente perfeição na obra camoniana. ${ }^{357}$ De fato, Nabuco diverge dessa postura crítica (ou a-crítica), desde seu livro de 1872. Ele, em "Camoens, the lyric poet", com efeito, observa: "Every truly great work must contain much rock by the side of the gold. I find dreary, long passages in Dante, Milton, or Camoens." ${ }^{358}$ Essas linhas certamente nos forçam a repensar qualificação de Carlos Daghlian acerca das três conferências camonianas, para quem estas seriam "apreciações e não crítica das obras do poeta",359, ou ainda, Nabuco teria escrito e proferido "uma apologia em vez de uma apreciação crítica dos poemas de Camões"360.

Também o conferencista desqualifica comparações entre obras-primas, no intuito de se estabelecer se esta ou aquela canção de Camões, como o fizeram alguns comentaristas, é melhor: "All classification of them is only a personal caprice of the critic"361 e já em "The place of Camoens in literature" apregoava: "All is equally good that is really created. You

\footnotetext{
${ }^{356}$ NABUCO(b), 1924, p.3. Tradução: "seus poderes divinatórios" (NABUCO, 1940, p.35)

${ }^{357}$ Cf. NABUCO(b), 1924, p.3.

${ }^{358}$ NABUCO(b), 1924, p.3. Tradução: “Em toda obra-prima, há muito cascalho misturado com o ouro. Descubro longas passagens tediosas tanto em Dante, quanto em Milton ou em Camões". (NABUCO, 1940, p.35)

359 DAGHLIAN, 1988, p.31.

360 DAGHLIAN, 1988, p.33.

${ }^{361} \operatorname{NABUCO}(\mathrm{b}), 1924$, p.22. Tradução: “Quaisquer classificações, porém, não passam de cap richo pessoal do crítico". (NABUCO, 1940, p.56)
} 
cannot graduate perfection."362 Apenas haveria credibilidade a comparação, se fosse realizada por um "superior poet" aos autores confrontados, solução que definitivamente desautorizaria - pode-se dizer - todos os críticos. Em outro passo de "Camoens, the lyric poet", se Storck datava certo soneto camoniano como escrito na manhã de seu desterro de Lisboa e Teófilo Braga, na manhã de sua partida para as Índias, o conferencista, diante de um poema que tematiza a dor da separação dos amantes, observa que uma terrível comoção poderia advir de uma separação menos drástica, e, sendo assim, com boa dose de ironia, completa: "This is a point which lovers can judge better than critics. ${ }^{363}$

A questão de como Nabuco passa a lidar com a crítica literária e a recepção camoniana oitocentista será aprofundada no capítulo seguinte de nosso trabalho. Nesse capítulo, articularemos essas afirmações das conferências pronunciadas nos Estados Unidos com outros textos do próprio Joaquim Nabuco que nos ajudarão a compreender melhor seus fundamentos e motivações na recepção da obra camoniana.

Em Camões e o descobrimento do mundo, conferência proferida no Rio de Janeiro, Jaime Cortesão afirma que "um dos homens que mais profundamente compreendeu os Lusíadas foi Joaquim Nabuco",364 sendo "The place of Camones in literature" "um dos melhores balanços críticos, conhecidos"365 da epopeia quinhentista. Cortesão observa que boa parte da recepção crítica camoniana oitocentista elegeu como chave de interpretação d' $O s$ Lusíadas o fato de ser essa uma obra renascentista. Assim o conceberam Oliveira Martins, Antero de Quental, Wilhelm Storck, Carolina Michaëlis e outros. Nabuco, segundo o historiador português, teria, a partir de Humboldt e Quinet, compreendido o épico camoniano

\footnotetext{
${ }^{362}$ NABUCO(b), 1924, p.24. Tradução: “Tudo é bom, logo que for criado. A perfeição não se gradeia”. (NABUCO, 1940, p.29)

363 NABUCO(b), 1924, p.14. Tradução: "É ponto a ser resolvido melhor por namorados do que por críticos" (NABUCO, 1940, p.46)

364 CORTESÃO, 1944, p.9.

${ }^{365}$ CORTESÃO, 1944, p.10.
} 
como "poema do Oceano" e "poema da criação do Novo-Mundo", além de "santuário e relicário de Portugal", para dizer, em segundo plano, "aliás com exagero, que os Lusíadas são o único poema que reflecte e resume o Renascimento". ${ }^{366}$ Passemos a discutir a relação de Camões e de sua epopeia com o Renascimento, segundo o embaixador brasileiro.

Assim como no livro de 1872 e no discurso de 1880, Joaquim Nabuco, nas conferências de 1908-09, reflete sobre Camões como poeta que expressou a nacionalidade portuguesa, sendo "above all his Nation's poet", 367 mas também autor que escreveu obra - Os Lusíadas - que consistiria em 'the only poem that reflects and resumes it [a Renascença], the only one written under its inspiration". ${ }^{368}$ No capítulo anterior deste trabalho, apontamos para essa tensão entre o nacional e o universal que a leitura nabucoana fazia ver em 1872 e 1880 . Na primeira década do século XX, essa tensão ainda marca presença na compreensão crítica do autor pernambucano. Em 'The place of Camoens in literature", a primeira impressão d'Os Lusíadas destacada é a do "Country-worship", 369 elemento que restringiria enormemente o público leitor que quisesse compreender plenamente a epopeia, dado que "Portions of it can only be appreciated with the Portuguese soul", ${ }^{370}$ isso para não mencionarmos, mais uma vez, a perda que haveria na leitura da obra traduzida, sobretudo, para uma língua não neolatina. Contudo, é na condição de autor d'Os Lusíadas que Camões se torna apenas comparável aos poetas considerados universais Homero e Virgilio, pois o quinhentista português e os clássicos grego e romano produziram obras fincadas em terreno "eternal, as the one on which was raised the Parthenon". ${ }^{371}$ Quanto ao receio por Camões passar a ter, progressivamente,

\footnotetext{
${ }^{366}$ CORTESÃO, 1944, p.10.

367 NABUCO(a), 1924, p.2. Tradução: "antes de tudo o poeta da sua nação". (NABUCO, 1940, p.2)

368 NABUCO(a), 1924, p.16. Tradução: "o único poema que a reflete e resume [a renascença], o único que se escreveu sob sua inspiração". (NABUCO, 1940, p.18)

369 NABUCO(a), 1924, p.6. Tradução: “culto da pátria”. (NABUCO, 1940, p.7)

370 NABUCO(a), 1924, p.7. Tradução: “Certos trechos só podem ser apreciados pela alma lus itana”. (NABUCO, 1940, p.7-8)

371 NABUCO(c), 1924, p.25. Tradução: “eterno, como aquele em que se elevou o Partenon". (NABUCO, 1940, p.28)
} 
menos leitores, estando em declínio a cultura latina e o desprestígio da história e da língua de Portugal, Nabuco se mostra tranquilo, com base no exemplo da situação do autor da Ilíada, o qual "has no readers compared with the writers of the day, still we must not fear for him". 372

Também em 1872 e 1880 Nabuco insistira em aproximar Camões a Homero, nisso contribuindo ou, pelo menos, endossando a homerização do quinhentista português (conforme vimos nos Capítulos 1 e 2 desta tese). Em várias passagens do ensaio de 1872, com efeito, deparamo-nos com comparações aproximativas entre Camões e Homero, Os Lusíadas e a Ilíada, o que aí se explicava em a epopeia camoniana, conquanto ser classificada como individual, conter traços que a caracterizariam também como nacional. Isso se reproduz no seguinte trecho de "The Lusiads as epic of Love": "Camoens is really a combination of two souls: he is a Greek poet, as well as a modern one."373 Desse modo, a ideia de renascimento estaria fielmente realizada na poesia camoniana. Para demonstrá-lo, o embaixador brasileiro aponta para o episódio do Adamastor e o da Ilha dos Amores. Sobre o malogrado amante de Tétis, em "The place of Camoens in literature", lemos que se trata mais do que "a greater creation on modern Literature", ${ }^{374}$ seria "a living Myth". ${ }^{375}$ Em "The Lusiads as epic of love", "Modern literature has added no myth but this one to the grand series of Homer and Hesiod". ${ }^{376}$ Sobre o célebre episódio do canto nono da epopeia, seria esse, conforme a primeira conferência, "The last of the large frescoes worthy of the Renaissance"377 e "Cupid's

\footnotetext{
372 NABUCO(c), 1924, p.23. Tradução: "não tem leitores, comparado com os escritores em voga. No entanto, ninguém receia por ele". (NABUCO, 1940, p.98)

373 NABUCO(c), 1924, p.17. Tradução: “Camões, em verdade, é uma fusão de duas almas. É poeta grego e é poeta moderno". (NABUCO, 1940, p.90)

${ }^{374}$ NABUCO(a), 1924, p.13. Tradução: "criação que na literatura moderna não foi superada". (NABUCO, 1940, p.14)

375 NABUCO(a), 1924, p.13. Tradução: "mito vivo". (NABUCO, 1940, p.14)

${ }^{376}$ NABUCO(a), 1924, p.14. Tradução: "Foi es te [o Adamastor] o único mito que a literatura moderna acresceu à alta série de Homero e de Hesíodo". (NABUCO, 1940, p.87)

377 NABUCO(a), 1924, p.15. Tradução: “O último dos grandes afrescos digno da Renascença”. (NABUCO, 1940, p.18)
} 
forge is worth the Greek imagination in all its freshness", ${ }^{378}$ conforme a terceira conferência.

A conclusão acerca da mitologia clássica n'Os Lusíadas, temo-la expressa em 'The place of Camoens in literature":

The Mythology of the Lusiads seems an evolution of the old Mythology such as would perhaps have taken place if Paganism had lasted ten centuries more by the side of Christianity. It is living. As a Poetics, it has kept all its plastic force. It is not a pastiche; it is a perfect survival. ${ }^{379}$

Américo da Costa Ramalho, em sua conferência pronunciada em Nova Iorque, em 1972, e publicada no volume intitulado Estudos camonianos, em 1975, avalia as que proferiu Joaquim Nabuco nos Estados Unidos, para concluir que "a mais surpreendente transformação nas suas ideias a respeito de Camões se verifica no capítulo da Mitologia de Os Lusíadas".380 O estudioso português acresce que seria "na sua compreensão dos Lusíadas como poema do Renascimento, sobretudo na relação estabelecida entre o poder da criação plástica da imaginação do poeta e a pintura mitológica da época, que se encontra o mais original dos pontos de vista de Nabuco". ${ }^{381}$ Isso porque o embaixador brasileiro, já mais maduro conhecedor das artes plásticas da Antiguidade que pudera admirar em museus da Europa, tinha-se dado conta dos

[...] méritos de Camões como pintor verbal do Renascimento, artista plástico por meio da palavra criadora, [...] muito mais altos [do que os dos poetas da Antiguidade], sendo ele português, nascido num dos lares da ContraReforma, do Humanismo cristão, do que se tivesse visto luz e vivido em

\footnotetext{
${ }^{378}$ NABUCO(c), 1924, p.17. Tradução: “Esta oficina de Cupido tem toda a pujança da imaginação grega em plena florescência". (NABUCO, 1940, p.90)

379 NABUCO(a), 1924, p.16-17. Tradução: “A mitologia dos Lusíadas parece evoluir da antiga, como se o paganismo tivesse durado mais dez séculos, vivendo ao lado do cristianismo. Ali está realmente vivo. Conserva, como fator poético, toda sua pujança plástica. Não é pastiche. A sobrevivência é perfeita". (NABUCO, 1940, p.19)

380 RAMALHO, 1975, p.112.

${ }^{381}$ RAMALHO, 1975, p.115.
} 
Itália pela mesma altura, rodeado de um ambiente artístico parcialmente paganizado e mais afim do seu génio de poeta renascentista. ${ }^{382}$

De fato, para quem oscilava, em 1872, entre enaltecer (“As mais bellas pinturas dos Lusiadas são desenhadas com as cores de Homero",383) e recriminar (“Se á maneira do poeta grego, seu mestre [Camões] houvesse elle creado uma theogonia, se houvesse povoado com creações suas o mundo dos espiritos, [...] os Lusiadas não teriam certas belezas convencionaes, nem pareceriam ás vezes obra de outro seculo"384) e passava a considerar, quase três décadas depois, tais méritos do quinhentista português, é uma transformação e tanto de concepção crítica. O certo é que, definitivamente, Joaquim Nabuco deixa de se incomodar com a mitologia n'Os Lusíadas - e, vale destacar, de seu convívio com o maravilhoso cristão, questão não mais tocada em seus textos camonianos desde 1880 - e, sobretudo nas conferências de 1908-09, vê em Camões o grande poeta renascentista que consegue ressuscitar a mitologia antiga nos tempos modernos e, inclusive, contribuir com a criação de um ser mitológico, o Adamastor.

No discurso proferido a 10 de junho de 1880, Joaquim Nabuco parecia lamentar que o quinhentista português não tivesse ido ao berço e polo do Renascimento, "em vez de ficar encerrado no horizonte moral de um povo [o português do século XVI] que não sentia a Arte", pois se

[...] tivesse ido á Italia, e se houvesse misturado em Roma com os discipulos de Raphael, com os amigos de Ticiano, com os adoradores de Miguel Angelo, familiarizando-se com os frescos do Vaticano, e a tragedia humana da Sixtina; como elle não teria crescido pelo Arte, e pela liberdade! ${ }^{385}$

\footnotetext{
382 RAMALHO, 1975, p.116.

${ }^{383}$ NABUCO, 1872, p.153.

384 NABUCO, 1872, p.153.

${ }^{385}$ NABUCO, 1980, p.13.
} 
A hipótese desse "se" levava o orador convidado pelo Real Gabinete Português de Leitura do Rio de Janeiro a acreditar na escrita de outras "obras-primas" (outras epopeias?), além d'Os Lusíadas. ${ }^{386}$ Já na conferência pronunciada a 14 de maio de 1908, o embaixador explica aos estudantes de Yale:

Camoens never left Portugal, except to fight in Africa and to fight in India. He had, however, the intuition of the Renaissance as perfect as if he had been, like Francisco de Hollanda, in the company of Michelangelo, Baccio Bandinelli, Perino del Vaga, Sebastiano del Piombo, and, last but not least, Vittoria Colonna, marchesa di Pescara. ${ }^{387}$

Em "The place of Camoens in literature", o embaixador brasileiro passa a enxergar uma vantagem em o quinhentista não ter ido à Itália, para poder ter senso maior ainda da Renascença, porém, se assim fosse, "he would not have been the national poet he is".388 Todavia, tanto no discurso de 1880 quanto na conferência de 1908, o autor pernambucano confessa-se convencido de que a viagem ao Oriente foi fundamental para a concepção e escrita d'Os Lusíadas.

Para concluir esta apresentação das conferências camonianas pronunciadas nos EUA, detenhamo-nos um pouco no que tange à compreensão a respeito do gênio e sua afinidade com o sofrimento, compreensão expressa nestes termos no ensaio de 1872: "Se nenhuma desgraça tivesse-lhe [a Camões] atravessado a vida, e se elle fosse sempre o amante de

\footnotetext{
${ }^{386}$ Cf. NABUCO, 1980, p.13.

${ }^{387}$ NABUCO(a), 1924, p.16. Tradução: “É curioso que Camões, nunca tendo saído de Portugal, senão para baterse na África e na Índia, tenha tido uma intuição tão perfeita da Renascença, quanto poderia ter Francisco de Holanda ou ele mesmo como se tivesse tido ensejo de frequentar Michelangelo, Baccio Bandinelli, Perimo del Vaga, Sebastiano del Piombo e, última, sem ser menor, Vittoria Colonna, marqueza de Pescara." (NABUCO, 1940, p.18-19)

${ }^{388}$ NABUCO(a), 1924, p.21. Tradução: "ele não seria o poeta nacional que é". (NABUCO, 1940, p.24)
} 
Catharina de Athaide, não teriamos os Lusiadas." Obviamos, havemos de ter em mente que Joaquim Nabuco, acompanhado da supremacia crítica de sua época, que a poesia épica de Camões era mais importante, ou melhor do que a lírica. Sendo assim, o infortúnio garantira ao vate quinhentista uma imortalidade ligada a uma obra maior, expressão máxima de sua genialidade, que o levaria a suplantar Petrarca. A postulação dessa "alliança antiga do talento e da miseria", 389 esse raciocínio causa (sofrimento)/consequência (Os Lusíadas) também aparece no discurso de 1880 , nesta passagem:

Em Lisbôa, com as occupações insignificantes, mas forçadas, da vida da Côrte, com as pequenas conspirações da inveja, e as feridas do amor proprio, com o espirito alegre, sociável, e superficial, que é preciso ter nas salas, com a intervenção benevola da Inquisição e dos Jesuitas, o que teriam sido os Lusiadas? ${ }^{390}$

E, finalmente, em "The place of Camoens in literature", a estada no Oriente, resultado de uma cadência ininterrupta de desfavores do destino, é, da mesma forma, avaliada: “[...] without the voyage to India it is impossible to imagine the Lusiads. ${ }^{, 391}$

Joaquim Nabuco, portanto, passou toda sua vida de convívio com a biografia e a obra camoniana convicto da relação gênio-sofrimento, patente resquício romântico. Em seu diário, ensinava para si mesmo, a 25 de outubro de 1907:

Que grande obra foi produzida na boa fortuna? Dos grandes poemas quase todos foram obra da adversidade, do exilio, do ostracismo social, da pobreza. Muitos dos grandes poetas teriam sido toda a vida políticos, soldados, cortesãos, ou teriam feito somente obras ligeiras, se a adversidade não os

\footnotetext{
${ }^{389}$ NABUCO, 1872, p.268.

${ }^{390}$ NABUCO, 1980, p.16-17.

${ }^{391}$ NABUCO(a), 1924, p.21.
} 
tivesse forçado a viver em si mesmos, consigo, sós. Dante, Camões, Milton. Comparar com Goethe. ${ }^{392}$

Fosse como fosse, estava fechado o ciclo da grande poesia, conforme já assinalamos relativamente a comentários nostálgicos de Nabuco sobre as condições da arte na sua época (séculos XIX e XX). Sublinhemos mesmo os exemplos pensados pelo autor pernambucano Dante, Camões, Milton, Goethe - todos não pertencentes ao período em que viveu o embaixador brasileiro.

\section{3) Um Camões pan-americanista?:}

Antes de levar adiante nossa análise específica dessas três conferências, cumpre esclarecer o pan-americanismo e o monroísmo, trazendo outras informações e discussões em torno de como Joaquim Nabuco apropriou-se desse ideário de política externa.

Conforme a lição de Anatoli Glinkin, repassada por Paulo José dos Reis Pereira, havemos de distinguir primeiramente "duas etapas pan-americanistas na história do continente: uma latino-americana (desde as independências hispano-americanas até o final do século XIX) e outra norte-americana (desde o fim do século XIX)". ${ }^{393}$ Como se está a ver, a acentuada modulação ideológica do pan-americanismo - de uma proposta de solidariedade e união baseada em suposta unidade identitária e cultural do sul das Américas para uma vigilância imperialista encabeçada pelos Estados Unidos sobre todo o Continente - mais do que por influxos cronológicos, se daria pela migração geográfica. A considerada primeira etapa do pan-americanismo tem por motivador os movimentos de independência das colônias

\footnotetext{
392 NABUCO, 2006, p.654.

393 PEREIRA, 2006, p.112.
} 
espanholas, emancipadas nas décadas iniciais do oitocentos. Em seguida, personagens históricos como Simon Bolívar e Francisco de Miranda lideram tentativas seja de formar uma única república, num propósito romântico e utópico de "resgatar a base cultural hispanoamericana", ${ }^{394}$ chegando a conceber "um imperador inca governando Estados indoamericanos federativos", 395 seja de simplesmente estabelecer "uma confederação de nações, separadas no exercício de questões particulares, mas unidas especialmente para garantia da independência adquirida e da integridade territorial contra potências estrangeiras, promoção de relações pacíficas entre os membros desse grupo e estímulo à prática de uma política externa ativa"; 396 além disso, "era essencial ter uma nação liberal de peso que pudesse dar proteção a essa iniciativa, enquanto ela não pudesse sustentar-se por si mesma. Essa nação seria a Inglaterra". ${ }^{397}$ Ambos os projetos revelar-se-iam tão irrealizáveis quanto ingênuos, sobretudo no que se refere à suposição de uma unidade identitária e cultural hispanoamericana, de um interesse por parte das oligarquias de cada país da América hispânica em unir-se num espírito de fraternidade, e de uma boa vontade zeladora britânica. Somar-se-ia ao contexto de instabilidade política das novas nações americanas, que contribuiu para a nãoconcretização do pan-americanismo em sua primeira etapa,

[...] a mensagem presidencial norte-americana que originou a Doutrina Monroe, apesar de não ser propriamente uma proposta integradora que rivalizasse com as idéias de integração bolivarianas, acabou the tirando grande parte da força por se propor a "garantir" a independência das nações recém-descolonizadas. As independências pareceram, assim, protegidas de investidas européias e uma das grandes motivações da união latina se viu questionada. $^{398}$

\footnotetext{
394 PEREIRA, 2006, p.114.

395 PEREIRA, 2006, p.114.

396 PEREIRA, 2006, p.114.

397 PEREIRA, 2006, p.114.

398 PEREIRA, 2006, p.115.
} 
Pronunciada em 1823, a mensagem do presidente Monroe determinava como hostilidade aos Estados Unidos qualquer propósito europeu de recolonizar territórios independentes nas Américas ou intervir nas questões desse Continente. Por outro lado, os norte-americanos também se comprometiam a não interferir nos assuntos da Europa. Estava, assim, sedimentado o terreno em que se apoiaria a segunda etapa do pan-americanismo. Reis Pereira distingue uma e outra manifestação pan-americanista nestes termos:

As diferenças entre o monroísmo e o pan-americanismo latino são bem claras. Ao passo que o último se pretendia universalista, já que buscava o diálogo com as outras partes do mundo a partir da confederação dos países latinos, o monroísmo tendia a isolar o hemisfério e dicotomizar o mundo em duas partes. Da mesma forma, seja na sua essência, interpretação ou desenvolvimento, o pressuposto da idéia bolivariana era o multilateralismo, ao passo que a de Monroe pressupunha unilateralidade. Especialmente por essa última característica fica claro que o pan-americanismo latino visava o bem comum dos países envolvidos no movimento, algo distante do monroísmo que tinha como preocupação essencial os benefícios para os próprios Estados Unidos. ${ }^{399}$

Em fins da década de 1880 - momento inserido no princípio do que E. Hobsbawm denominou de a era dos impérios -, os Estados Unidos, já se impondo, juntamente com a Alemanha, como nova potência no cenário econômico mundial, retomam a doutrina monroísta, em prol da garantia de um vasto mercado consumidor para sua indústria e comércio em franca expansão, resguardando-se inclusive do imperialismo europeu, que poderia interessar-se por recolonizar algum território na América Latina. Theodore Roosevelt, presidente da já grande potência norte-americana, entre 1901 e 1909, consolida o monroísmo, concretizando-o com a ameaça de que "os Estados Unidos poderiam ocupar militarmente os 
países que não pagassem regularmente suas obrigações, assumindo, mais do que nunca, um papel de polícia em seu hemisfério". 400 Era a conhecida política do Big Stick.

Se o regime monárquico de D. Pedro II canalizara o principal do esforço de sua política externa em direção à Europa, a república proclamada em 1889 não tardaria a redirecioná-lo para os Estados Unidos, então maior comprador dos produtos exportados pelo Brasil. A nova postura diplomática, incentivada pelo pertencimento ao mesmo continente e por mesmo tipo de governo, daria seu primeiro largo passo com a abertura da primeira embaixada do País em Washington, decisão cuja importância assim explicitam Ricardo Pereira de Azevedo e Tiago Coelho Fernandes:

Se em Washington somente sete representações desse nível (Alemanha, Áustria-Hungria, França, Grã-Bretanha, Itália, México e Rússia), o Rio de Janeiro não era sede de representação diplomática alguma com tal status. A atitude do governo brasileiro, portanto, não foi apenas um mero ato administrativo, mas um sinal real de aproximação com aquele país, constituindo-se no paradigma de nossa política externa nas décadas posteriores. $^{401}$

$\mathrm{Na}$ avaliação de Marco Aurélio Nogueira, o engajamento de Nabuco no panamericanismo não se compara ao que realizou como líder do movimento abolicionista, tendo sido sua "concepção a respeito da união americana primária e jamais chegou a ombrear com a tese de 'deseuropeização' da política externa brasileira implementada por Rio Branco". ${ }^{402}$ Também Nogueira sublinha a "ingenuidade e precipitação" do diplomata pernambucano frente ao papel dos EUA conforme o roteiro monroísta. Fazendo vistas grossas à postura policial do big stick, assumida pelo presidente norte-americano Theodore Roosevelt, tão

\footnotetext{
${ }^{400}$ AZEVEDO \& FERNANDES in NABUCO, 2011, p.9. vol 1.

${ }^{401}$ AZEVEDO \& FERNANDES in NABUCO, 2011, p.10. vol 1.

402 NOGUEIRA, 2010, p.260.
} 
admirado por Nabuco, este "jamais admitirá que os Estados Unidos estavam se convertendo em país expansionista e dominador: suas pretensões hegemônicas derivavam apenas do maior peso que jogavam na esfera internacional e eram, nessa medida, benéficas para a América Latina". ${ }^{403}$ A conclusão acerca da atuação do embaixador do Brasil em Washington é, por fim, de que

Nabuco estava desarmado para enfrentar o problema, pois apenas intuía a mudança que se operava no mundo, baralhando as relações internacionais. Não compreendia o caráter mais profundo daquela fase de transição - os avanços do capitalismo monopolista, com seu corolário maior, o imperialismo - e, nessa medida, extraía conclusões algo precipitadas e rígidas, embora não totalmente discordes das tendências em curso na diplomacia brasileira. ${ }^{404}$

Paulo José dos Reis Pereira, por sua vez, aconselha cautela na aplicação do termo panamericanista para definir o pensamento diplomático de Nabuco em sua última década de vida e, especialmente, como embaixador em Washington. Isso porque, para Nabuco, não se trataria preponderantemente da postulação da "união e solidariedade incondicional de todos os países americanos", 405 mas, sobretudo, de uma "visão hierarquizada dos países, na sua idéia de relacionamentos preferenciais independentes e na perseguição de interesses nacionais brasileiros alheios a de outros". ${ }^{406}$ De qualquer forma, para Reis Pereira: "A disposição panamericanista de Nabuco é complexa, difusa e, mais importante, em alguns momentos contraditória, característica recorrente da sua trajetória de vida."407

\footnotetext{
403 NOGUEIRA, 2010, p.271-272.

${ }^{404}$ NOGUEIRA, 2010, p.277.

${ }^{405}$ PEREIRA, 2006, p.124.

${ }^{406}$ PEREIRA, 2006, p.124.

${ }^{407}$ PEREIRA, 2006, p.124.
} 
Dentre os autores que comentaram as conferências camonianas que Nabuco proferiu nos Estados Unidos, parece haver consenso no que se refere a motivações menos literárias do que políticas ou diplomáticas. Segundo Angela Alonso, ele teria difundido “o panamericanismo também obliquamente, ao falar de Camões", bem como o quinhentista português teria sido "o mote para afirmar a grandeza cultural da Ibéria e singularizar o Brasil em meio à América Latina". ${ }^{408}$ Graça Aranha já havia afirmado algo parecido na introdução à edição que preparou das correspondências entre os dois amigos, Joaquim Nabuco e Machado de Assis:

Nas suas conferências é sempre do Brasil que fala, da antigüidade do nosso espírito nacional, das nossas possibilidades, e, para terminar o ciclo da vida espiritual, foi inconscientemente, mas imperiosamente, levado a revelar Camões aos americanos, realçar a epopéia portuguesa, tratar enfim da emoção e da glória em que nos foi gerada a nação. ${ }^{409}$

Em prefácio ao livro Pages choisies, de Joaquim Nabuco, o autor de Canaã noticia aos leitores de língua francesa: "De retour aux États-Unis, il y poursuivit son action panaméricaniste, à laquelle vient s'ajouter une vive activité littéraire sous forme de conférences. Sa fidélité à Camöens lui suggère l'idée de révéler le poète et l'epopée des Lusiades aux Américains. ${ }^{\natural 10}$ Em trabalho de referência incontornável sobre o assunto, Os discursos americanos de Joaquim Nabuco, Carlos Daghlian postula que, nessas suas conferências,

\footnotetext{
${ }^{408}$ ALONSO, 2007, p.339.

${ }^{409}$ ARANHA, 2008, p.84.

${ }^{410}$ ARANHA, 2008, p.247. Tradução nossa: "De volta aos Estados Unidos, el e levou adiante sua campanha panamericanista, à qual veio se associar uma viva atividade literária na forma de conferências. Sua fidel idade a Camões Ihe sugere a ideia de apresentar o poeta e Os Lusíadas aos norte-americanos".
} 
Nabuco pretendia fazer com que seus ouvintes percebessem o significado da cultura luso-brasileira, apresentando-lhes Camões, a língua portuguesa e o Brasil. Ele esperava que tal conhecimento acabaria por levar a uma melhor compreensão entre os Estados Unidos e o Brasil. ${ }^{411}$

E mais adiante, afirma ainda Daghlian:

Ao relacionar Camões, o Brasil, os Estados Unidos e o Pan-Americanismo, Nabuco acreditava que o conhecimento de Os Lusíadas faria com que os americanos se interessassem pela história de Portugal. Isso teria como conseqüência o estudo do português e um maior conhecimento do Brasil. ${ }^{412}$

Seja por tal ou qual razão, com essa ou aquela intenção diplomática, é curioso que o embaixador do Brasil não tenha eleito autor brasileiro para cumprir os propósitos de propagandear seu País nos Estados Unidos. Na época da polêmica com José de Alencar (década de 1870), o jovem pernambucano dizia nada encontrar de relevante na literatura escrita em seu País. ${ }^{413}$ Contudo, no biênio 1908-09, o Brasil já contava com obras do quilate de Memórias póstumas de Brás Cubas (1881), Dom Casmurro (1900), de Machado de Assis, reiteramos, amigo de Nabuco, e até Os sertões (1902), de Euclides da Cunha, que, ademais, foi imortal da Academia Brasileira de Letras, da qual o romancista carioca era presidente e o diplomata pernambucano, secretário-geral. Pelo menos, a 3 de abril de 1909 (isto é, semanas antes de Nabuco pronunciar "Camoens, the lyric poet"), Oliveira Lima, outro diplomata pernambucano, proferiria na Sorbonne a conferência "Machado de Assis et son oeuvre littéraire" ("Machado de Assis e sua obra literária"), em evento intitulado "Festa da Intelectualidade Brasileira", organizado por Anatole France. ${ }^{414}$

\footnotetext{
411 DAGHLIAN, 1988, p.28.

412 DAGHLIAN, 1988, p.29-30.

413 Cf citação 514 desta monografia (Capítulo 4).

414 Não apenas nisso Oliveira Lima se desentendeu com Nabuco. O chamado por Gilberto Freyre "Quixote gordo" também era acerbo crítico do pan-americanismo defendido entusiasticamente pelo conterrâneo, o que acabou por motivar o fim das relações cordiais entre um e outro.
} 
Mas também a eleição de Camões àquela altura provoca o incômodo diante do fato de que Joaquim Nabuco se arregimentara nas hostes pan-americanistas, política de fechamento a intervenções europeias no Continente americano. Nos contornos contextuais das conferências camonianas pronunciadas em 1908 e 09, portanto, há essa dissonância ou incoerência, para as quais os que trataram desses textos não chamaram a atenção. Também não as explica a contento frase de conferência realizada pouco após a "The place of Camoens in literature", na mesma Universidade de Yale: "Parece natural sequencia falar do Brazil, depois de me haver occupado dos Lusiadas, uma vez que Brasil [sic] e os Lusiadas são as duas grandes obras de Portugal". ${ }^{415}$ Essa frase, em que a altivez retórica sobrepuja o valor argumentativo, dá início a "O espírito de nacionalidade na história do Brasil", em que podemos hoje ler: "O espirito nacional desenvolveu-se, lá [no Brasil] como aqui [nos EUA], dês dos seus primeiros dias", 416 a que se segue todo um histórico de confirmação dessa união identitária que diferenciava a colônia americana e a metrópole europeia, até esbarrar na ligação brasileira com os norteamericanos no tocante a um ponto decisivo:

Tanto comprehendeu logo o Brazil o bem que importava para a America Latina a Doutrina Monroe, que foi a primeira das novas nações que the deu apoio. Sessenta dias depois de ser emitida, na Mensagem de 3 de Dezembro de 1823, mandou o Governo Brazileiro ao seu Representante em Washington instrucções para propôr ao Governo Americano uma Alliança offensiva e defensiva. Muito antes da nossa Independência, quanto até pensar nisso era crime, já os Patriotas brazileiros punham os olhos na nova democracia americana. Já em 1787 tentaram interessar em sua causa a Jefferson, então em França, e elle lhes não recusou sua sympathia, ainda que estava obrigado, como Agente Diplomatico, a lhes legar cooperação. Parte dahi o curso da sympathia nacional, da nossa parte [para com os EUA]. ${ }^{417}$

\footnotetext{
415 NABUCO, 1911, p.121.

${ }^{416}$ NABUCO, 1911, p.121.

417 NABUCO, 1911, p.133.
} 
Seja como for, o próprio Nabuco, em carta a Machado de Assis, de 8 de junho de 1908, após, portanto, ter proferido "The place of Camoens in literature", noticiava que "[...] me tornei propagandista aqui dos Lusíadas", esclarecendo o propósito de que "Faço isto também em honra da nossa língua, que é tomada como um dialeto do espanhol, o que dá à América Espanhola, com as suas dezoito nações, certo prestígio sobre nós". ${ }^{418}$

Tomemos esse esclarecimento de Nabuco a Machado como mote para nossa discussão a seguir. $\mathrm{Na}$ primeira das três conferências camonianas, podemos distinguir como o embaixador brasileiro, mais do que divulgar o poeta português e Os Lusíadas para os estudantes universitários norte-americanos, procura fazê-los se interessar pelo autor e obra, assinalando aspectos dessa epopeia que falariam diretamente a supostas características do povo dos EUA. Certa situação, a de que

[...] the subject of the Lusiads, the discovery of the East, appeals more to the European than to the American imagination. For the Americans Vasco da Gama is a secondary figure to that of Columbus. The true interest of Discovery centres for us in the crossing of the Atlantic and in the finding of America[, $]^{419}$

situação essa elencada como um dos obstáculos para o interesse universal (e pan-americana) pela poesia camoniana, é posta em contestação. Para isso, Nabuco argumenta que as grandes navegações europeias só teriam sido possíveis, graças aos avanços e conhecimentos náuticos dos portugueses, com base nos quais certamente Cristóvão Colombo veio a descobrir as Américas. Adiante, ao explicitar as impressões provocadas pel'Os Lusíadas, o conferencista

\footnotetext{
${ }^{418}$ NABUCO, 2008, p.155.

${ }^{419}$ NABUCO(a), 1924, p.3. Tradução: "o assunto dos Lusíadas, a descoberta do Oriente, fala mais à imaginação europeia do que à americana. Para os americanos, Vasco da Gama é figura inferior à de Colombo. Para nós o verdadeiro interesse de qualquer descobrimento está na travessia do Atlântico e da descoberta da América". (NABUCO, 1940, p.3)
} 
defende que esse seria "the poem of colonization, of far away enterprise, and therefore the poem of the building up of the New World" ${ }^{, 420}$ e que

The two shores that the Lusiads seem destined to link are not so much those of Europe and Asia, as those of Europe and America, because, as has so often been said, the Lusiads is the poem of commerce and industry, the poem of the Modern Age, and in all this the part of America is and shall be much larger than that of Asia. ${ }^{421}$

Eis aí semeada a semente argumentativa de como a epopeia camoniana teria uma ligação muito íntima com as Américas, cujas nações se construíram, sobretudo, pelos movimentos migratórios. Mas também cumpre destacar que, com isso, Joaquim Nabuco acaba por afirmar a atualidade da epopeia de Camões, obra que, no contexto da projeção cultural ibérica, ensejou o seguinte diagnóstico de Antonio Candido: "Enquanto a Espanha, com o Quixote e a picaresca, abria caminho para o romance, isto é, um gênero inovador que serviria para exprimir o moderno, Portugal produzia Os Lusíadas [...], num gênero [...] destinado a perder atuação rapidamente. ${ }^{, 42}$ Por outro lado, devemos também destacar que o então quase sexagenário Joaquim Nabuco, filho do século XIX, apresentava concepções esboçadas sobre literatura e, digamos, modernidade, numa perspectiva marcadamente nostálgica e passadista. $^{423}$ A esse propósito, o parágrafo com que encerra a última das três conferências camonianas é significativo:

\footnotetext{
420 NABUCO(a), 1924, p.12. Tradução: "Os Lusíadas são o poema da colonização, dos empreendimentos longínquos, e são, portanto, o poema da criação do Novo Mundo". (NABUCO, 1940, p.13)

${ }^{421}$ NABUCO(a), 1924, p.12. Tradução: “As duas margens opostas que os Lusíadas parecem destinadas a unir são menos as da Europa e da Ásia que as da Europa e da América. Como já muitas vezes tenho dito, os Lusíadas são o poema da era moderna. Ora, o papel da América é e será neste aspecto muito maior que o da Ásia". (NABUCO, 1940, p.13)

422 CANDIDO, 2004, p.143.

${ }^{423}$ No Capítulo 4 desta monografia, discutiremos mais profundamente a concepção classicizante de Joaquim Nabuco acerca de literatura.
} 
There is now about forty years that I follow the march of literature, and its relative place in the world seems to me to become each day smaller. This, we must remember, is no longer the Age of writing; it is already the Age of typewriting. The Manuscript is dead. I doubt if the affinities of inspiration with the machine will ever be the same as with the pen. Allow me to express to you my whole faith. I do not believe that there is anywhere through heavens a register for money deals, however great; but I believe there is one for intellectual creations, and that the work of Homer, Dante, Camoens, Shakespere, and their like, transcends the Earth. ${ }^{424}$

O embaixador brasileiro, portanto, parece apontar para um descompasso entre a sua época e o que compreende que fosse o lugar da literatura, o qual, aliás, estava sendo reproposto em moldes revolucionários pelas vanguardas modernistas europeias (em fevereiro de 1909, conforme o dissemos anteriormente, o italiano Marinetti publicava seu "Manifesto do futurismo", em ataque frontal e impiedoso a tudo o que Joaquim Nabuco concebia no âmbito literário). A modernidade aceitável para o conferencista parecia encerrar-se na sua própria definição de Camões, como poeta que fundia duas almas: "he is a Greek poet, as well as a modern one."

Voltemos ao tema da ligação estabelecida pelo conferencista pernambucano da poesia camoniana com a cultura norte-americana. Em "The place of Camoes in literature", Nabuco situava como uma das impressões provocadas pel'Os Lusíadas 'the gospel of true American spirit", 425 denominado "strenuous life", o que também teria impelido os navegantes portugueses comandados por Vasco da Gama. Importa esclarecer que essa expressão "strenuous life" - tinha dado título a um discurso de Theodore Roosevelt, proferido a 10 de abril de 1899, em Chicago e seria, segundo o político norte-americano, o ideal maior dos

\footnotetext{
${ }^{424} \operatorname{NABUCO}(c), 1924$, p.23. Tradução: “Há agora uns quarenta anos que acompanho a marcha da literatura, e, a cada dia, seu lugar relativo neste mundo me parece menor. Já não estamos, é mister lembrar-se, na era da letra traçada a mão, mas na da máquina de escrever. Morreu o manuscrito. Duvido que as afinidades de inspiração sejamas mesmas com a máquina que com a pena. Deixai-me exprimir minha fé. Não creio que haja nos céus registro algum para as transações financeiras, por maiores que sejam. Creio, porém, que existe registro par as criações intelectuais, e que a obra de Homero e de Dante, de Camões, de Shakespeare e de seus pares transcende a terra." (NABUCO, 1940, p.98)

${ }_{425}$ NABUCO(a), 1924, p.20. Tradução: "o verdadeiro evangel ho do que é o espírito americano". (NABUCO, 1940, p.21)
} 
EUA na busca do progresso desse país e do mundo no século XX. Obviamente, Nabuco prestava, em sua conferência de quase dez anos depois, homenagem ao então presidente que dizia tanto admirar.

Ratificando sua compreensão d'Os Lusíadas como o "poema de Vênus", em "Camoens, the lyric poet", Joaquim Nabuco ensinava às alunas do Vassar College que a mulher ocupava lugar de destaque na epopeia camoniana. Não apenas a deusa do amor, mas também a Rainha Maria, Inês de Castro, Dona Leonor de Sá expressariam, assim como a poesia lírica camoniana, comprovariam "o culto da mulher" professado pelo quinhentista português. ${ }^{426}$ Está claro que a referência ia ao encontro do que o conferencista afirmava ser "the greatest human fact of the twentieth [century]", 427 isto é, "the social progress of woman", 428 que, ao lado da imigração, "the greatest human fact of the nineteenth", ${ }^{429}$ eram ambos "principally American facts". 430

A defesa de que haveria uma sintonia na obra camoniana com o povo norte-americano está acompanhada de outra acentuada preocupação do embaixador brasileiro: de, mediante a

\footnotetext{
${ }^{426} \mathrm{Na}$ verdade, nessa sua segunda conferência norte-americana, Nabuco não estava apenas adaptando seu assunto ao público. O suposto "culto da mulher", especialmente verificado n'Os Lusíadas, tinha sido considerado no ensaio de Oliveira Martins. Conforme edição revista de 1891, o historiador português explicava: "Nos Lusíadas há três mulheres: Vénus, Maria a formosíssima, e a linda Inês. Em todas elas se vê o traço fundamental do carácter feminino; a meiguice. São todas três medianeiras; e os três episódios femininos formam porventura os melhores, e, decerto, dos dez ou doze melhores episódios da epopeia. São todas três submissas, mas activas; e o feminino eterno do poeta vai crescendo, desde o amor naturalista de Vénus, cinzelada com um buril celinesco, até o martírio augusto de Inês, tendo de permeio a voz eloquente de Maria, quando implora de seu pai a salvação da família intei ra, completamente feita de abnegação. Amante, esposa e mártir: nestas três palavras se resume a essência daquelas que, junto de nós, são até certo ponto o símbolo real da existência, porque são a poesia da espécie." (MARTINS, 1952, p.47) Também Miguel Lemos, no ensaio de 1880 , chamava a atenção, relativamente a Os Lusíadas, para o papel da figura feminina, especialmente representada por Vênus, no poema. A deusa romana do amor, na epopeia camoniana, seria "l'être qui sanctifie et purifie notre personnalité grossière", (LEMOS, 1880, p.231) / tradução nossa: "o ser que santifica e purifica nossa personalidade grosseira", leitura que se pauta na função superior, social e moral, exercida pela mulher segundo o positivismo comtiano.

${ }^{427}$ NABUCO(b), 1924, p.27. Tradução: “o maior acontecimento do século [vinte]". (NABUCO, 1940, p.65)

${ }^{428}$ NABUCO(b), 1924, p.27. Tradução: “o progresso social da mulher" (NABUCO, 1940, p.65) É este assunto do oitavo capítulo, intitulado "A nova mulher", de $A$ era dos impérios, de Hobsbawm.

${ }^{429}$ NABUCO(b), 1924, p.27. Tradução: "o maior acontecimento do dezenove" (NABUCO, 1940, p.65) Segundo Hobsbawm, "nunca foi tão fácil encontrar um lugar para onde emigrar que entre 1880 e 1914". (HOBSBAWM, 2003, p.105)

${ }^{430}$ NABUCO(b), 1924, p.27. Tradução: "realizações primordialmente americanas” (NABUCO, 1940, p.65)
} 
divulgação de Camões, singularizar o Brasil em meio à América Latina. Em 'The Lusiads as epic of love", já de início providencia Joaquim Nabuco desfazer um equívoco generalizado nos EUA, o de que "in Brazil we speak Spanish", ${ }^{431}$ tendo-se em vista que "The expression Spanish America is used here for the whole of Latin America". ${ }^{432}$ Conquanto tivesse dito, na primeira das conferências camonianas, serem o português e o espanhol "two sister languages", 433 explica agora que "Portuguese is a very distinct language from Spanish, and was bound to have a different literature". ${ }^{434}$ Fato significativo dessa distinção residiria na "predominance in Portuguese of the word saudade and its premature death in Spanish". ${ }^{435}$ Em passagem da conferência de 21 de abril de 1909, Nabuco afirmara que a saudade é "the predominant sentiment of the race", 436 "the soul, the essence, of Portuguese", 437 e, finalmente, "the most beautiful word of any language". 438

Três textos literários bastam para termos em mente o significado dessa palavra no imaginário luso-brasileiro oitocentista, a que o embaixador brasileiro recorria. Um seria o Camões, de Almeida Garrett, cujos versos iniciais definem:

Saudade! gosto amargo de infelizes!

Delicioso pungir de acerbo espinho,

Que me estás repassando o íntimo peito,

Com dor que os seios d'alma dilacera,

- Mas dor que tem prazeres! - Saudade $!^{439}$

\footnotetext{
431 NABUCO(c), 1924, p.1. Tradução: "no Brasil falamos espanhol”. (NABUCO, 1940, p.72)

432 NABUCO(c), 1924, p.1. Tradução: "O termo América espanhola é por vós aplicado a toda a América latina". (NABUCO, 1940, p.72)

433 NABUCO(a), 1924, p.7. Tradução: "duas línguas irmãs" (NABUCO, 1940, p.39)

434 NABUCO(c), 1924, p.2. Tradução: "o idioma português é muito diverso do espanhol, e assim era fatal que tivesse literatura distinta". (NABUCO, 1940, p.72)

435 NABUCO(c), 1924, p.2. Tradução: "predominância da palavra saudade em português e [o] seu prematuro desaparecimento em espanhol". (NABUCO, 1940, p.72)

${ }^{436}$ NABUCO(b), 1924, p.17. Tradução: "o sentimento predominante da raça". (NABUCO, 1940, p.49)

${ }^{437}$ NABUCO(b), 1924, p.19. Tradução: “a alma, a essência da língua portuguesa”. (NABUCO, 1940, p.50)

438 NABUCO(c), 1924, p.18. Tradução: "vocábulo o mais lindo que existe em qualquer idioma" (NABUCO, 1940, p.49)

${ }^{439}$ GARRETT, 1963, p.301. vol.II
} 
O romantismo brasileiro também teria sua obra de estreia a marcar, curiosamente, a importância do mesmo sentimento para a afirmação da nacionalidade de uma ex-colônia recém-independente: os Suspiros poéticos e saudades, de Gonçalves de Magalhães. Todavia, Olavo Bilac sintetizaria muito da discussão que o companheiro de geração desenvolve em suas conferências sobre Camões nos EUA, no célebre soneto simplesmente intitulado "Língua portuguesa" e coligido do volume Tarde, de 1919. Os versos desse poema, com efeito, acentuam a beleza em contraste com o desprestígio mundial do idioma, referem-se a Camões - homenageado como seu maior poeta - e colocam a palavra saudade num lugar central:

Última flor do Lácio, inculta e bela, És, a um tempo, esplendor e sepultura:

Ouro nativo, que na ganga impura

A bruta mina entre os cascalhos vela...

Amo-te assim, desconhecida e obscura, Tuba de alto clangor, lira singela, Que tens o trom e o silvo da procela, E o arrolo da saudade e da ternura!

Amo o teu viço agreste e o teu aroma De virgens selvas e de oceano largo! Amo-te, ó rude e doloroso idioma,

Em que da voz materna ouvi: "meu filho!",

E em que Camões chorou, no exilio amargo,

$\mathrm{O}$ gênio sem ventura e o amor sem brilho! ${ }^{440}$

Com as explicações em torno da palavra-síntese da raça lusitana, que não fora incorporada pelo léxico espanhol, Joaquim Nabuco objetiva não somente reforçar a especificidade cultural do Brasil em meio à América latina, mas também reverter, aos olhos dos norte-americanos, o quadro de desprestígio de um país que os hispano-americanos, historicamente, consideravam uma "ovelha negra", dado o antigo

${ }^{440}$ BILAC, 1997, p.272. 
[...] contraste entre o republicanismo hispano-americano e o monarquismo brasileiro, diferença que se expandia para outros âmbitos, como o das alianças e dos projetos nacionais. O sistema escravista brasileiro foi outro ponto de divergência com os países latinos, bem como as questões litigiosas fronteiriças. $^{441}$

Posto que tenha combatido o regime escravocrata do País nas décadas de 1870 e 1880 e se rendido, no início do século $\mathrm{XX}$, ao regime republicano - essas duas das mais assinaladas razões da negritude da pelagem brasileira no sul do continente -, Joaquim Nabuco estava mais propenso, com seu pan-americanismo, a aproximar o Brasil dos Estados Unidos do que da América latina. Assimétricas as relações entre a ex-colônia portuguesa e as ex-colônias espanholas, conforme ilustra Antonio Candido com o exemplo de que "se for [...] à Bolívia, um brasileiro se esforçará por falar portunhol, enquanto um boliviano no Brasil falará tranqüilamente o seu bom castelhano" ${ }^{442}$ além da vitória pelo apelo moderno de D. Quixote obra-prima da literatura da Espanha - sobre Os Lusíadas - obra-prima da literatura de Portugal - ${ }^{443}$ o embaixador recorre a uma comparação metafórica, sem possibilidade de fundamentação racional ou lógica:

There is no name in Portugal in the field of art to be opposed to Velasquez, or Murillo, or Goya. She has no Cathedrals to be compared to those of Burgos or Toledo. Nothing to rival the Alhambra. Yet if you put all that together in a scale of the balance, adding to it Don Quixote, and put the Lusiads in the other, I doubt which would weigh more, just as if all ancient

\footnotetext{
441 PEREIRA, 2006, p.122.

442 CANDIDO, 2004, p.143.

443 Consideração que subscreveria com prazer na da naci onalista António José Saraiva, que enxergava no cantor d'Os Lusíadas um quixotesco preservador de ideais cavaleirescos não mais compatíveis com a época (o quinhentos), contexto mais bem captado por Cervantes. Cf. os artigos que compõem o volume $O$ Tejo é um rio controverso, de Jorge Fernandes da Silveira (2008).
} 
Art was weighed against the Iliad, I believe Homer's scale would remain immovable. ${ }^{44}$

Parece-nos claro que Camões e Os Lusíadas como temas das conferência pronunciadas pelo embaixador brasileiro, adepto fervoroso do monroísmo, eram utilizados com duas finalidades confluentes: a) aproximar os EUA do Brasil, país este herdeiro da cultura portuguesa, sendo que a epopeia camoniana teria muitos pontos afins à cultura norteamericana; b) podemos dizer que afastar o Brasil do restante da América latina, de fato, singularizando-o nessa parte do continente.

A acreditarmos em tal leitura, o Camões luso-brasileiro de 1872 e 1880 ganha a roupagem nova do pan-americanismo tal qual Nabuco mais ostensivamente defendia e propagandeava.

${ }^{444}$ NABUCO(c), 1924, p.3. Tradução: "No campo da arte Portugal não pode opor nome algum aos de Velásquez, Murillo ou Goya. Não tem catedrais que se comparem com as de Burgos ou Toledo, e nada que rival ize com Alhambra. No entanto, se puserdes tudo isso num lado da balança, acrescentando-Ihes o Dom Quixote, e no outro puserdes os Lusíadas, não sei que lado pesará mais, assim como, se toda a Arte antiga se opusesse da mesma forma à llíada, creio que a posição de Homero permaneceria inalterável. (NABUCO, 1940, p.73) 


\section{CAPÍTULO 4:}

JOAQUIM NABUCO LEITOR DE CAMÕES:

O ESTIGMA DA CONTRADIÇÃO 


\section{1) Nabuco e a crítica literária:}

Em tempos nos quais os Cultural Studies deixaram sua marca indelével na concepção crítica de literatura, os textos que Joaquim Nabuco dedicou a Camões nos impõe uma sensação de desatualidade. Pois o cânone literário ocidental - tão acusado há décadas de excluir autores e obras em nome da hegemonia étnica, político-econômica, geográfica, de gênero... - é tudo quanto o autor pernambucano defendeu, chegando a afirmar, em Pensées détachés, que as letras "ne peuvent être qu'une aristocratie". ${ }^{44}$ Com efeito, Homero, Virgilio, Dante, Petrarca, Shakespeare e Goethe são referências as mais frequentes nos seus trabalhos camonianos, à parte - é claro - o próprio Camões, dentre o panteão dos escritores e poetas.

$\mathrm{Na}$ segunda das conferências pronunciadas em inglês, a 21 de abril de 1909, perante estudantes do Vassar College, o embaixador brasileiro dizia da importância de se ler os clássicos, quando preteridos pela leitura de obras de autores contemporâneos: "If one lets his taste for the writings of the day absorb him, he overlooks that sacred duty of watching over the precious deposits of the human mind, of keeping fresh and retentive the memory of our race, of increasiag its touch with the past the more it drifts away from us." ${ }^{, 46}$ Especificamente quanto aos anos de 1908-09, porém, Nabuco deixava claro e também nas entrelinhas que a época da grande literatura, e da grande arte, havia morrido; a recente invenção da máquina de escrever era uma das últimas pás de terra lançada para dentro de sua cova. E Camões, nesse contexto, encontrava-se em situação ruim: além de poeta pertencente à literatura de um país periférico, de ter escrito em língua desprestigiada no cenário mundial, padecia das consequências do declínio da cultura latina, e ascensão concomitante da anglo-germânica.

\footnotetext{
${ }^{445}$ NABUCO, 1906, p.120. Tradução nossa: "não podem ser senão uma aristocracia".

${ }^{446}$ NABUCO(b), 1924, p.27. Tradução: "Quem se deixa absorver pelos escritos da própria época, falta aos deveres sagrados de velar sobre os depósitos preciosos do espírito humano, conversar a frescura retentiva da memória de nossa raça, aumentar nosso contato com o passado à medida que este se vai afastando". (NABUCO, 1940, p.64)
} 
Ainda que o conferencista tentasse se mostrar convencido de que o lugar do poeta d'Os Lusíadas na literatura universal não estava ameaçado, uma vez que sua obra seria como estrelas no firmamento que a observação de uns poucos telescópios garantiam a admiração delas aqui na Terra, essa mesma metáfora denunciava como Nabuco sentia distante - a anosluz, diríamos - o tempo dos autores clássicos ${ }^{447}$ em relação a sua época.

Não devia imaginar Joaquim Nabuco que, naqueles anos de exercício diplomático nos EUA, vanguardas europeias já preparavam a revolução das letras, que assumiriam não sua mera modernidade, mas a condição de modernistas. De qualquer modo, Nabuco revelou ter uma mínima consciência ou intuição do que se passava no âmbito artístico e literário do começo do novecentos, tendo prognosticado, ao fim e ao cabo, que a máquina de escrever transformaria definitivamente a relação do escritor com o texto.

Se voltarmos, no contexto brasileiro, a meados do século $\mathrm{XX}$, chegaremos a outra camada da sensação de desatualidade dos estudos camonianos de Nabuco. Naquela época, Afrânio Coutinho encampava verdadeira batalha contra o que ele mesmo tachava de crítica de rodapé ou impressionista, na proposta de uma análise literária científica, acadêmica, instrumentalizada pelo New Criticism. ${ }^{448} \mathrm{Na}$ década de 1970, já consolidado o ensino universitário de Letras nos principais centros do País, o estruturalismo seria adotado por parte significativa dos professores de $3^{\circ}$ grau e pesquisadores brasileiros, de modo a deixar ainda mais ultrapassada a crítica praticada na segunda metade do século XIX. Mas a verdade é que Joaquim Nabuco tampouco chegou a exercer a crítica literária com a dedicação de Araripe

\footnotetext{
447 No sentido de canônico.

${ }^{448}$ Coutinho el egera Álvaro Lins como inimigo maior contra o qual lutar, uma vez que este era o mais influente nome da crítica que se veiculava nos jornais, capaz de, algumas vezes, determinar o sucesso ou insucesso de uma obra ou de um autor. Afrânio Coutinho, em sua campanha, reivindicava "uma substituição do jornal pela universidade como 'templo da cultura literária' e da figura do crítico enciclopédico e impressionista, com sua habilidade para a crônica, pelo do professor universitário, com seu jargão próprio e uma crença inabalável no papel 'modernizador' que poderia exercer no campo dos estudos literários. Tratava -se, em suma, de substituir o rodapé pela cátedra." (SÜSSEKIND, 2002, p.22)
} 
Júnior, Sílvio Romero e José Veríssimo, ${ }^{449}$ nem tendo sido essa, aliás, ao que consta, uma das ambições do abolicionista, que, por toda a vida, padeceu de frustrações literárias. Seus estudos sobre Camões, especialmente, ora integram manifestações comemorativas - caso do livro de 1872 e do discurso de 1880 -, ora se enquadram no gênero textual destinado originalmente a ser ouvido - caso também do discurso de 1880 e das três conferências proferidas nos Estados Unidos. Dentre as ocasiões nas quais se expressou publicamente a respeito do poeta de "Alma minha gentil de que te partiste", o mais adequado gênero para o exercício da crítica, isto é, Camões e Os Lusíadas, que, parcialmente endossando o julgamento de Teófilo Braga, Américo da Costa Ramalho afirma, no tocante às informações históricas, "nada adiantou e ficou mesmo aquém do que se poderia saber no seu tempo", ${ }^{450}$ Nabuco confessava ele mesmo o propósito maior de homenagem do que de contribuição aos estudos camonianos: pretendia tanto "dar sempre e sinceramente os fructos de minha idade",451 quanto pagar "o tributo de uma admiração sempre crescente á Luiz de Camões no terceiro centenario de seu poema". ${ }^{452}$

Em termos sintéticos, podemos compreender a atividade crítica nabucoana como diletante, isto é, como resultado não de uma vivência profunda e profissional com o objeto literário, mas de uma necessidade de expressar publicamente a admiração pelo quinhentista português - frente ao que discutimos nos capítulos anteriores desta monografia, obviamente havia outras questões em jogo. Seria infeliz a tentativa de compará-lo ou aproximá-lo de um Araripe, de um Romero, de um Veríssimo, os maiores representantes da crítica brasileira no

\footnotetext{
449 Vale trazer aqui o que informa Benedito Nunes: "[No Brasil], a crítica literári a começou a fazer sua própria história no fim do séculoXIX, com a chamada geração de 70, republicana e anti -escravagista, de Sílvio Romero e José Veríssimo, que, na passagem para a escola naturalista [...] adotou o positivismo de Auguste Comte, o evolucionismo do naturalista alemão Ernst Haeckel (1834-1919) e a filosofia evolucionista do inglês Herbert Spencer (Primeiros princípios, 1862), que eram as 'idéias novas' da época, mas sem perder de vista o postulado por essa mesma geração recebido do romantismo, da equivalência, na literatura brasileira, entre afirmação de nacionalidade e caráter estético." (NUNES, 2007, p.54-55)

450 RAMALHO, 1975, p.107. Por outro lado, Afrânio Peixoto - mais generoso do que criterioso - escreve que o Camões e Os Lusíadas de Joaquim Nabuco "resume o que se sabia na época". (PEIXOTO, 1947, p.389)

${ }^{451}$ NABUCO, 1872, p.16.

452 NABUCO, 1872, p.17. Em 1880, Afonso Celso Jr. publica ensaio sobre Camões, saindo-se com a justificativa para um livro que "pouco vale" de que tinha vinte anos. (Cf. RAMALHO, 1975, p.103)
} 
oitocentos. É de se notar, a propósito, que esses três ocuparam-se principalmente da literatura brasileira, ou antes, de uma produção literária de autores brasileiros, procurando fazer desta, mediante discussões e argumentos em torno da nacionalidade do que escreveram os escritores e poetas analisados, uma literatura brasileira. Naturalmente, não era esse o interesse de Joaquim Nabuco, ao debruçar-se sobre Luís de Camões. Com algo mais afim ao que o pernambucano legou à camonologia deparar-nos-emos em Oliveira Martins e Francisco Leoni, portugueses que tiveram a mesma ideia do pernambucano, a de prestar homenagem em volume ao tricentenário de publicação d'Os Lusíadas; nos positivistas Teixeira Mendes e Miguel Lemos, este autor do ensaio que analisamos no Capítulo 1; aquele, de discurso proferido também a 10 de junho de 1880. Ou ainda em conferência pronunciada em Buenos Aires, um século depois, por ninguém menos que Jorge Luis Borges, que dizia: "Hay algo, hay algo misterioso en Camoens, no sólo en su destino sino en el destino de la obra, que hace que nos congreguemos esta tarde, que hace que la tarde nos congregue aquí para honrar su alta memoria." ${ }^{453}$ Em comum, o propósito humanista de afirmação e celebração dos valores da alta literatura ocidental.

O fato incontestável é que o autor de Balmaceda, em balanço de toda sua existência, concentrou a maior parte de suas energias intelectuais (e físicas) em questões de ordem política, seja o abolicionismo, seja a manutenção reformista da monarquia, seja a defesa da posse brasileira de territórios da Guiana reivindicados pela Inglaterra, seja o panamericanismo monroísta. Diante de tudo isso, pode-se afirmar que, para Nabuco, a importância de Camões é restrita e secundária, observação que ainda se reforça com o fato de que não deixou escapar a oportunidade de discutir a questão do escravo em alguns versos d'Os Lusíadas (no livro de 1872 e no discurso de 1880) e arregimentado o poeta português

\footnotetext{
${ }^{453}$ BORGES, 2001, p.25.
} 
como garoto-propaganda da cultura luso-brasileira dentro de um contexto diplomático em prol do estreitamento de laços entre Brasil e Estados Unidos.

Seja como for, a problemática relação de Joaquim Nabuco com a atividade crítica não se ateve a questões de gênero textual e circunstâncias; tinha também a ver com sua própria concepção acerca dela. Em Pensées détachés, publicado em 1906, temos um autor bastante disposto desqualificar o ofício crítico. E, assim, atacava: 'Il n'y a pas d'usurpation plus indélicate en littérature [...] que [...] de se croire la conscience vraie de l'oeuvre d'autrui. En ce cas, l'honneur de la création reviendrait de droit au critique. ${ }^{, 454}$ Ou também: "Les critiques sont les blasés de esprit. Rien n'est plus faux que l'air de fraîcheur et de jeunesse qu'ils affectent; on dirait que le lecture peut encore leur donner des sensations vraies. ${ }^{` 455}$

Tanto em 1872 e quanto em 1880, o autor pernambucano sustentava a opinião de se manter o que havia de lendário na biografia camoniana e não desmenti-las com certezas históricas e científicas, em proveito da maior popularidade do poeta: "A illusão é uma parte de nós mesmos, e a melhor; não é possivel arrancal-a sem que no espaço que ella occupa fique um vazio que nada enche". ${ }^{456}$ Também assim pensará Massaud Moisés, quem, provavelmente sem ter em vista os textos nabucoanos, veio a perguntar: "Que mal há que o mito se sobreponha aos fatos praticamente improváveis, se ele estimular o leitor à contemplação e admiração do legado poético camoniano?" ${ }^{457}$ Com esse pensamento, Joaquim Nabuco contestava uma preocupação dos estudiosos de Camões em determinar o que foi fato ou lenda ou ainda equívoco na reconstituição da biografia do poeta quinhentista. Wilhelm Storck, por exemplo, na alentada obra Luis de Camoens Leben (Vida de Luís de Camões),

\footnotetext{
${ }^{454}$ NABUCO, 1906, p.116. Tradução nossa: “Não há usurpação mais indelicada em literatura do que se acreditar a verdadeira consciência da obra al heia. Nesse caso, a honra da criação converter-se-ia em direito à crítica". ${ }^{455}$ NABUCO, 1906, p.118. Tradução nossa: "Os críticos têm a insensibilidade do espírito. Nada é mais falso do que o ar de frescor e juventude que eles afetam; dir-se-ia que a leitura pode ainda dar-lhes sensações verdadeiras".

${ }^{456}$ NABUCO, 1980, p.13.

${ }^{457}$ MOISÉS, 1968, p.9.
} 
publicada em 1890, recrimina o biógrafo setecentista Faria e Souza por ter dado "por factos verdadeiros e indubitaveis uma serie de hypotheses vãs e phantasticas; servindo-se de poesias apocryphas, tiradas sem escrupulo das obras de outros poetas peninsulares, de nomeada geral, que elle explorou sem dó nem consciencia, a favor do seu Mestre idolatrado" ${ }^{458}$ ou seja, o próprio Camões. Relativamente à questão da cidade em que teria nascido esse poeta, Wilhelm Storck debruça-se sobre uma série de eventos, documentos, evidências para concluir: 'Decide a questão, a meu vêr, o facto da residencia da familia Camões em Coimbra, durante seculos; depois a affeição constante do poeta pela cidade do Mondego; e por ultimo, os versos autobiographicos da quarta Canção." ${ }^{459}$ No ensaio de 1872, Nabuco resolvia a polêmica pela simples diplomacia e efeito retórico: "Pertencendo menos á Lisboa, á Santarém, á Alemquer, á Coimbra, elle [Camões] pertence mais á Portugal." ${ }^{460}$ Isso porque, no discurso de 1880 , afirmaria: "A verdade, senhores, é divina; mas a certeza nem sempre vale mais do que a duvida. ${ }^{461}$

Nas três conferências de 1908-09, Joaquim Nabuco expressa com veemência, por vezes irônica, sua opinião acerca da crítica literária, em especial acerca da recepção camoniana. Em Camões e Os Lusíadas, o jovem ensaísta havia contestado os comentaristas do século XIX D. Francisco Alexandre Lobo e o Bispo de Vizeu, para quem Camões ou não teria amado ou teria amado não apenas uma mulher, vendo neles integrantes de uma "escola histórica”, à qual contrapõe o imaginário cultural popular: “[...] a immortalidade que o poeta quiz dar á sua amada triumphará de todos os argumentos da critica". ${ }^{462}$ Quatro décadas depois, em "Camoens, the lyric poet", parecia o velho Nabuco reproduzir, em outras palavras,

\footnotetext{
${ }^{458}$ STORCK, 1898, p. 29.

459 STORCK, 1898, p.117.

460 NABUCO, 1872, p.30. Obviamente em outra proposta discursiva, Lima Barreto lançará mão do mesmo recurso para caracterizar o patriotíssimo protagonista de Triste fim de Policarpo Quaresma: “Não se sabia bem onde nascera, mas não fora decerto em São Paulo, nem no Rio Grande do Sul, nem no Pará. Errava quem quisesse encontrar nele qualquer regionalismo: Quaresma era antes de tudo brasileiro." (BARRETO, 1998, p.17) ${ }^{461}$ NABUCO, 1980, p.14.

462 NABUCO, 1872, p.36.
} 
sua lição de juventude: "Willing and reasoned admiration is never such a perfect tribute as the unconscious one [...]." ${ }^{\text {463 }}$ É que o sentido profundo da obra de um gênio, a qual "an immemorial prescription raises above [criticism]", ${ }^{464}$ revelar-se-ia mais facilmente para o povo do que para o crítico, uma vez que o gênio "draws from [the masses] the inspiration that it returns to our mind in poetry, as the cloud gives back to the earth in fertilizing rain the water it drew from the ocean". ${ }^{465}$ A 21 de abril de 1909, no Vassar College, Joaquim Nabuco definia a atividade crítica como "an assumption of superiority" 466 por parte de quem assume ser juiz de suas próprias leis; desse modo, o hábito de classificar esta ou aquela obra como melhor, muito praticado pela exegese oitocentista, seria apenas "a personal caprice of the critic" 467 Desse modo, trazendo para cá a distinção benjaminiana entre "crítico de arte" (Kunstkritiker) e "juiz da arte" (Kunstrichter), que Luiz Costa Lima retoma em Limites da voz, Joaquim Nabuco, em suas conferências de 1908-09, alveja os que, à maneira dos poetólogos renascentistas (entendidos como Kunstrichter) são ao mesmo tempo juízes e legisladores, diferentemente do Kunstkritiker, que "supõe a intervenção teórica e não a mera aplicação de normas existentes", 468 postura crítica que, a propósito, o embaixador parecia desconhecer, considerando-se o meio pouco propício à teorização como era, na época, o do país que representava em Washington. ${ }^{469}$

A reconversão de Nabuco ao catolicismo repercutiu sensivelmente na sua compreensão literária. No último parágrafo de "The place of Camoens in literature", o autor

\footnotetext{
${ }^{463}$ NABUCO(b), 1924, p.22. Tradução: “A admiração voluntaria e arrazoa da nunca é tributo tão perfei to quanto a admiração inconsciente, aquella que ignora onde principia e onde acaba." (NABUCO, 1940, p.56)

464 NABUCO(a), 1924, p.23. Tradução: "um preceito imemorial põe acima dos juízos [da crítica]". (NABUCO, 1940, p.27)

465 NABUCO(a), 1924, p.23. Tradução: "tira a inspiração [das massas] que depois restitui ao es pírito humano na forma de poesia, assim como a nuvem devolve à terra, em chuva fertilizante, a água que tirou do oceano". (NABUCO, 1940, p.27)

${ }^{466}$ NABUCO(b), 1924, p.22. Tradução: "uma autoinvestidura de superioridade". (NABUCO, 1940, p.56)

467 NABUCO(b), 1924, p.22. Tradução: “um capricho pessoal do crítico". (NABUCO, 1940, p.56)

468 LIMA, 2005, p.203.

469 Adiante, também na companhia de Luiz Costa Lima, consideraremos com mais vagar esse contexto brasileiro avesso ao exercício do Kunstkritiker.
} 
pernambucano situava o legado camoniano, e toda alta poesia, acima de quaisquer propósitos comparativos, e críticos, nestes termos: "The true law of criticism is found in the Genesis: 'And God saw that it was good.' All is equally good that is really created. You cannot graduate perfection. ${ }^{, 70}$ Ora, a passagem é ressonância nítida de outra que podemos ler em Minha fé, obra em que o embaixador brasileiro registrava as próprias motivações e convicções que o reaproximaram da religião católica:

O sentimento do belo, na criatura humana[,] é apenas um vestígio da alegria do criador, que a bíblia [sic] nos revela, quando ele viu que a sua obra era boa.

A emoção, a arte, a estética têm a mesma origem e fazem por sua vez, do instinto revelador do qual dimanam, o mais límpido, o mais delicado e o mais perfeito reflexo de Deus que se possa imaginar. ${ }^{471}$

A arte, portanto, segundo Joaquim Nabuco, conectaria o homem com Deus, levando o primeiro vislumbrar as emoções divinas logo após a criação. Todavia, também nesse livro não publicado em vida, o autor enxergava na análise um obstáculo para o mais livre trânsito através dessa ponte de ordem metafísica: "Sempre que a análise se interpõe entre uma emoção verdadeira, como a suscitada pela idéia de Deus, e a alma que a experimenta, a emoção é interceptada. ${ }^{472}$

Contrário ao fetichismo que observava ostentar a recepção de Teófilo Braga, Wilhelm Storck e Richard Burton, os quais somente teriam olhos para as perfeições da poesia camoniana, Nabuco, que, mesmo no ensaio de 1872, apontava para as deficiências d'Os Lusíadas, não obstante toda sua admiração por essa obra, com efeito, confessava, na

\footnotetext{
${ }^{470} \operatorname{NABUCO}(a), 1924$, p.25. Tradução: “A verdadeira lei da crítica está no Gênesis: “E Deus viu que estava bom”. Tudo é bom, logo que for realmente criado". (NABUCO, 1940, p.29)

${ }^{471}$ NABUCO, 1985, p.54.

${ }^{472}$ NABUCO, 1985, p.52.
} 
conferência de 21 de abril de 1909: "Every truly great work must contain much rock by the side of the gold. I find dreary, long passages in Dante, Milton, or Camoens." $" 473$ A essa afirmação, porém, sucede a exposição do que concebe o conferencista como diferença entre a obra imaginada e a obra efetivada:

[...] the author reads what he composes at the light of his inspiration; his writing is only the shadow of what rushes on him, either through his brain or through his heart, and which he tried to reduce to words. Other people read without any interior light to illuminate them as to the source of the thought; they receive only the ashes of the poet's inspiration, the echo of his inner song, and they interpret him, each in his own way. ${ }^{474}$

Fica, nessas linhas acima citadas, patente o substrato platônico (ou neoplatônico) ${ }^{475}$ da compreensão nabucoana acerca de literatura e da criação poética. A perfeição da obra circunscrevia-se ao plano das ideias do poeta; cabia ao leitor apenas ter acesso à physis textual, com seus cascalhos misturados ao ouro. Desse modo, podemos encontrar uma das prováveis razões que levaram Joaquim Nabuco a desqualificar o ofício do crítico literário, que, em relação ao escritor, conforme noticia Leyla Perrone-Moisés, em livro publicado em fins da década de 1970,

[...] sempre foi o segundo, o inferior, o servidor. Se percorrermos uma antologia da crítica desde a Idade Média (manifestações precursoras),

\footnotetext{
473 NABUCO(b), 1924, p.3. Tradução: "Em toda obra prima ha muito cascal ho misturado com o ouro. Descubro longas passagens tediosas tanto em Dante, quanto em Milton ou em Camões." (NABUCO, 1940, p.35)

474 NABUCO(b), 1924, p.3. Tradução: “O autor lê o que compõe à luz de sua inspiração e aquilo que ele escreveu é apenas uma sombra do que Ihe assaltou o espírito ou coração querendo ser reduzido a palavras. 0 leitor, desconhecendo essa luz interior que revelaria a fonte do pensamento, col he apenas, para interpretá -las como puder, as cinzas da inspiração do poeta, o eco do seu cantar interior". (NABUCO, 1940, p.35-36)

${ }^{475}$ Sabe-se que Platão foi uma das leituras diletas de Nabuco nos anos derradeiros de sua vida. No diário, o embaixador do Brasil em Washington registrava a 30 de outubro de 1907: "Ainda tenho tempo de ler $A$ República antes da chegada de Evelina [sua espoa]". (NABUCO, 2006, p.655) E a 17 de dezembro de 1909 transcrevia passagem de carta remetida a um amigo: "Estou agora embebido em Platão. Não sei se é tarde ao 60 anos para entrar para a Academia, mas é o mais conveniente preparo para a Eternidade." (NABUCO, 2006, p.715)
} 
passando pelo século XVII (data do batismo da crítica literária), até os nossos dias, verificaremos como constante, no testemunho dos críticos sobre sua atividade, o complexo de inferioridade. ${ }^{476}$

Filho do século XIX, quando "a hipertrofia do gênio tornará ainda mais evidente a pequena estatura do crítico", ${ }^{47}$ Joaquim Nabuco acabaria, nas suas conferências de 1908-09, a postular todo o seu idealismo platônico em matéria de literatura, concebendo "a obra como cópia e a crítica como simulacro", para aplicarmos a lição de Perrone-Moisés sobre o "o lugar crítico" no período anterior à Gilles Deleuze:

O crítico é aquele que está separado da Idéia, das essências, e que só pode reproduzi-las passando por um intermediário, o autor, o qual se encontra em comunicação direta com a origem ou centro. A cópia da cópia é ilegítima, degradada, suspeita de infidelidade, e só pode ser tolerada dentro de uma hierarquia bem definida: Idéia, cópia, simulacro - Criador, criador, crítico. ${ }^{478}$

Por isso, então, o conferencista brasileiro nos Estados Unidos contrapunha valorativamente, de um lado, a "willing and reasoned admiration" - a do crítico - e, de outro, uma admiração inconsciente, "that which does not know where it begins and where it ends". ${ }^{479}$ Era esta, afinal, como o próprio autor pernambucano registrava em Minha fé, a via direta única pela qual o leitor caminharia para vislumbrar o mais perfeito reflexo de Deus que se possa imaginar.

Tanta birra para com o exercício da crítica literária talvez se possa explicar também no fato de que Joaquim Nabuco se manteve aferrado a certas concepções românticas, ao longo de toda sua existência. Onde estaria o romantismo nabucoano? Sublinhamos em capítulos

\footnotetext{
${ }^{476}$ PERRONE-MOISÉS, 1978, p.16.

477 PERRONE-MOISÉS, 1978, p.17.

478 PERRONE-MOISÉS, 1978, p.20.

479 NABUCO(b), 1924, p.22. Tradução: “que ignora onde principia e onde acaba”. (NABUCO, 1940, p.56)
} 
anteriores, a dicção condoreira de passagens de Camões e Os Lusíadas e do discurso de 1880. $\mathrm{Na}$ verdade, metáforas altissonantes marcam mesmo textos nabucoanos de caráter eminentemente político. Mas o romantismo do Joaquim Nabuco leitor de Camões fica evidente na insistência com que relaciona gênio e sofrimento, numa típica afirmação da ligação entre vida e obra, pois não esclarecia, em 1880, não poder "estudar a obra [camoniana] sem fallar [ainda que] rapidamente do homem"? ${ }^{480}$ Numa das últimas páginas do ensaio de 1872, lemos: 'De certo a imaginação é uma causa eterna de soffrimento, e n'esse sentido pode-se dizer que os poetas teem em si a fonte de sua desgraça."481 Ilustrava-o o jovem autor com os exemplos de vida de Lord Byron e Álvares de Azevedo, dois poetas mártires para o romantismo ocidental e brasileiro, respectivamente. Já na terceira das conferências pronunciadas nos Estados Unidos, dizia: 'In fact, the great poet, as a human creator, leads a double and contrary life: enjoying real bliss in the companionship of his creatures during his greatest personal sorrows, and suffering agonies with them during his own raptures." ${ }^{482}$ Cumpre também mencionar, a esse propósito, a relação entre poesia e amor: “Os grandes poetas não parecem completos sem uma mulher que os acompanhe perante a historia. Só se comprehende que elles tenham inspiração, tendo amor", o que é dito no discurso de 1880. Embora aí se revelasse cônscio de que se trata de uma ilusão do sentimento popular, em Pensées détachés, 36 anos depois, Nabuco assumia-se iludido: 'Il n’y a que deux sources d'inspiration et de poésie pour l'homme: Dieu et la femme."483

Referimo-nos aqui, está claro, a somente parcela do romantismo; decerto não o de um Friedrich Schlegel, cuja "teoria romântica da crítica de arte" teria, segundo Walter Benjamin,

\footnotetext{
${ }^{480}$ NABUCO, 1980, p.12.

481 NABUCO, 1872, p.269.

482 NABUCO(c), 1924, p.5. Tradução: "De fato, todo grande poeta vive, enquanto criador humano, uma existência dupla e contraditória: gozando felicidade real na companhia de suas criações, embora cercado pelos maiores desgostos pessoais e sofrendo agonias com eles no meio do êxtase criador". (NABUCO, 194 0, p.76) ${ }^{483}$ NABUCO, 1906, p.97. Tradução nossa: "Não há mais do que duas fontes de inspiração e poesia para o homem: Deus e a mulher".
} 
um "caráter representativo" para os primeiros românticos alemães. ${ }^{484}$ Como se sabe, a literatura luso-brasileira oitocentista pouco ou nada dialogou com as reflexões teóricofilosóficas do idealismo alemão, preferindo o que se poetava e discutia na França. A verdade é que a crítica literária no Brasil do século XIX foi predominantemente pobre de reflexão, ao passo que riquíssima de erudição, verborragia, elogios mútuos e ataques levados para o lado pessoal. $^{485} \mathrm{O}$ seguinte excerto do prefácio a $O$ conde Lopo, de Álvares de Azevedo, aliás, um dos raros poetas nacionais oitocentistas dados ao exercício da crítica, foi com certeza motivado por esse lamentável ambiente pseudointelectual: 'E pois consolar-me-ei de ótima mente com as críticas. - Se os grandes as ouviram, por que queixar-me? Não é dos jasmineiros chamar os reptis? Não é das doçuras chamar os insetos?"486 Também estas palavras de Sílvio Romero, publicadas em 1880, devemos citá-las:

Não deixa de ser coisa perigosa o publicar neste país um livro de crítica.

Além da falta absoluta que existe aqui desta ciência e disciplina de espírito, acresce que os nossos ledores, grandes e pequenos, como bons burgueses, estão tranqüilíssimos com tudo quanto os cerca, e repelem soberbamente aquilo que os possa perturbar. ${ }^{487}$

\footnotetext{
${ }^{484}$ Cf. BENJAMIN, 2002, p.20.

485 No que se refere aos autores mais sérios do tempo de Joaquim Nabuco, como Sílvio Romero, Ara ripe Jr. e José Veríssimo, Antonio Candido ensina o que era uma análiseliterária, que "consistia no seguinte conjunto de procedimentos: 1) citação de trecho, que, pelo próprio critério da escolha, deveria tornar patente o que era o escritor estudado, conforme o ponto de vista do crítico; 2) resumo do enredo ou apresentação do assunto em suas diversas partes, o que pela tradição era a análise propriamente dita; 3 ) juízo de valor, em função de algum princípio geral, que podia ser a impressão de realidade, a beleza, a força, etc. Assim fazia Villemain, modelo de críticos portugueses e brasileiros, como Sotero dos Reis." (CANDIDO in ROMERO, 1977, p.xxvi -xxvii)

${ }^{486}$ AZEVEDO, 2000, p.377. Deixemos de lado a produção poética azevediana (em verso e prosa), para informar que o jovem autor paulista não era propriamente inimigo da atividade crítica, mas dos que dela se utilizavam para injustamente julgar obras alheias. Esta passagem de outro ensaio seu esclarece o ponto: "Se a crítica se ala nobre é quando [...] nas mãos de Sainte-Beuve, Th. Gautier, Chateaubriand, V. Hugo é ela o treslado de idéias filosóficas - e não a diatribe a rasgar com mãos ímpias o véu de vestal das criações da poesia." (AZEVEDO, 2000, p.664) 487 ROMERO, 1977, p.3.
} 
Interessante e profícuo para a compreensão das competências crítico-literárias de Joaquim Nabuco é o texto que lhe dedicou Luiz Costa Lima, texto este que integra o volume Intervenções, de 2002. Nesse artigo, intitulado "Nabuco: trauma e crítica", o autor maranhense-pernambucano não considera propriamente o que o abolicionista escreveu sobre Camões, mas acaba avaliando-o por tabela, a partir das conclusões acerca da atuação nabucoana na polêmica com José de Alencar, em 1875. Em livro anterior, Sociedade e discurso ficcional, Costa Lima já havia se debruçado sobre a célebre contenda, tendo por objetivo maior nela salientar e analisar manifestações do controle do imaginário, traduzidas em veto ao ficcional, na literatura (e na cultura) brasileira. Disso era exemplo contundente o julgamento negativo, por parte de Nabuco, da obra do romancista e dramaturgo cearense, com base em critérios de verossimilhança e de uma pedagogia morigeradora. Quanto à mesma polêmica, o artigo de Intervenções avalia aspectos argumentativos de ambos os participantes, muito próximos em suas bases, que, revelariam relativamente a um e a outro uma “impropriedade para a função que pretendiam realizar". ${ }^{488}$ Luiz Costa Lima elenca a "comunidade de critérios": "ataque personalizado, gramaticalidade, verossimilhança do usual, disputa por quem possuiria maior erudição" e, por fim, mais concernente a Nabuco, a ideia de que "o teatro e o romance de Alencar não retratam a sociedade e não respeitam a moral". ${ }^{489}$ Compartilhando os dois lados da polêmica "critérios tão grosseiros", indiferentes ou alheios a postulações estéticas kantianas e schlegelianas acerca da "autonomia da arte face às exigências da moral", tanto Joaquim Nabuco quanto José de Alencar atestariam aí "a inanidade do meio intelectual, mormente no âmbito da arte e da literatura", não só no Brasil do século XIX, mas também ainda nos dias atuais, legado aos que, embora desprendidos de critérios como os gramaticais e de verossimilhança, aferrar-se-iam à "explicação sociológica e

\footnotetext{
488 LIMA, 2002, p.351.

489 LIMA, 2002, p.352.
} 
realista". 490 "Nabuco: trauma e crítica", portanto, subscreve o que antes dissera Roberto Schwartz, em Ao vencedor as batatas, sobre a polêmica, questionando a patrioteira avaliação de Afrânio Coutinho, ${ }^{491}$ quem se preocupou em divulgá-la, hiperbolizando-lhe o valor:

[...] sobra-nos isenção, para, colocando a polêmica no seu tempo, compreender o que há nela de grandeza humana no espetáculo do debate entre dois dos maiores espíritos do Brasil. Um país que os possui, e uma literatura que suporta um choque intelectual daquela envergadura, dão-nos sobrados motivos de confiança. ${ }^{492}$

De fato, nada mais oposto às conclusões do artigo de Intervenções do que esta apreciação de Coutinho: “O choque de idéias literárias, de concepções críticas, de teorias e poéticas, sobreleva ao aspecto puramente pessoal da troca de doestos entre os dois admiráveis contendores." 493 Porém, o mais agudo no texto de Luiz Costa Lima refere-se ao trauma do regime escravocrata, cujos resquícios sociais nem mesmo a abolição logrou eliminar, trauma que teria imposto aos intelectuais brasileiros condições adversas ao exercício pleno do pensamento crítico. O caso de Joaquim Nabuco seria significativo em relação a isso, na medida em que ele revelaria consciência desses produtos nefastos da escravidão no Brasil. Tendo por divisa intelectual "Num país de escravos a missão dos poetas é combater a escravidão"494 e tendo associado a ideia de ficção a distanciamento da realidade, atestada pelas leis civis que ignoravam textualmente a existência do escravo, conforme frisa Nabuco em $O$ abolicionismo, a poesia e a literatura produzidas no Brasil não disporiam da liberdade de legitimação social que se verificaria na "Europa sem escravos". Os poetas e escritores

\footnotetext{
${ }^{490}$ LIMA, 2002, p.355.

491 "Ao contrário do que dizem, a sua disputa [de Nabuco] com Alencar é pobre em reflexão e baixa nos seus recursos [...]." (SCHWARTZ, 2003, p.39)

${ }^{492}$ COUTINHO, 1965, p.12.

${ }^{493}$ COUTINHO, 1965, p.9.

${ }^{494}$ LIMA, 2002, p.347.
} 
brasileiros, na compreensão nabucoana algo tácita, haveriam de aquiescer ao imperativo "da denúncia da mancha negra", 495 tal qual fazia Castro Alves, admirado pelo abolicionista, e diferentemente do que propunha Machado de Assis, cuja obra, não obstante a amizade entre os dois Joaquins, era pouco capaz de cativar a admiração do pernambucano. Desse modo, postula Luiz Costa Lima sobre a desqualificação de Nabuco para o ofício de crítico literário, patente na polêmica com Alencar:

Como ele próprio dissera, em um país que assenta na escravidão, todas as profissões são afetadas. Constitui-se um trauma, que, de uma maneira ou de outra, afetará todas as profissões. Nabuco será apenas um caso exemplar desse trauma pela maneira como formará seu arcabouço intelectual. Seu exame, portanto, nele não se encerra senão que serve de ponta de lança para entenderse a razão da debilidade da crítica, não só literária, mas sim de nosso espírito crítico, i.e., reflexivo. ${ }^{496}$

Com isso, o teórico de Limites da voz propõe esclarecimento da recepção de Um estadista do império, Minha formação, $O$ abolicionismo, Conferências e discursos abolicionistas e Campanhas de imprensa, obras estas de cunho político e historiográfico, como a contribuição nabucoana de maior valor, ao passo que "Só com bastante distância, o leitor encontrará interesse em suas tentativas de escritor e de crítico literário, em que Camões será figura freqüente". 497

A condição, algo consciente, de Joaquim Nabuco como crítico literário canhestro talvez - a endossar o que conclui Luiz Costa Lima - tenha sido anunciada muito cedo, já aos quinze anos, quando o filho do Senador do Império responde à apreciação pública que Machado de Assis the fizera dos versos de "Uruguaiana", declamados em solenidade na Arcádia Fluminense: “[...] ora dou asas à minha imaginação; mas um dia virá, e este dia talvez

\footnotetext{
495 LIMA, 2002, p.348.

496 LIMA, 2002, p.348.

497 LIMA, 2002, p.341.
} 
esteja perto, no qual me desligue completamente desse mundo de visionários, para ir tomar parte no grêmio daqueles que, mais chegados às realidades da vida, consideram este mundo como ele realmente é". ${ }^{498}$ Em parágrafo do capítulo "A crise poética" de Minha formação, o maduro autor ratifica a confissão do adolescente:

Quanto à grande poesia, à poesia de imaginação e criação, poema, romance, balada que fosse, para essa eu seria incapaz, além da insuficiência do talento, pela falta de coragem para habitar a região solitária dos espíritos criadores, os quais vivem naturalmente entre figuras tiradas de si mesmos, sem vida própria, autômatos da sua inteligência e da sua vontade, como em um sonho acordado. Nessa altura, onde tudo é fictício, tudo irreal, tudo fantástico, a poesia tem para mim o terror do adytum da Pítia. Mesmo quando as figuras sejam meigas, suaves, humanas, a criação envolve sempre alguma coisa de misterioso e terrível; a completa abstração, que ela supõe, da realidade exterior, do mundo dos sentidos, me daria vertigem. ${ }^{499}$

Em parentesco com essa reflexão contida no volume de 1901, aparecerá outra, registrada em diário, a 11 de outubro de 1905:

A poesia, em grande parte, é a obra do homem que se sente livre no espaço, rei do seu próprio pensamento, servido pelos seus desejos, em uma esfera onde nenhuma coação o poderia alcançar. Há alguma coisa de criminoso no poeta, do criminoso que se absolve a si mesmo e endeusa o crime, do espírito que rompe idealmente o pacto social e cria sua própria lei irresponsável. ${ }^{500}$

Recordemo-nos de que, na conferência de 21 de abril de 1909, o embaixador do Brasil em Washington via no crítico a coexistência do juiz e do legislador; logo acima, o próprio poeta é o criminoso que se absolve a si mesmo, resultando entre o escrito no diário e o dito na conferência numa disposição bastante interessante de termos, que nos levam a concluir que,

\footnotetext{
498 NABUCO in ARANHA, 2003, p.90.

499 NABUCO, 1981, p.64.

500 NABUCO, 2006, p.584.
} 
de fato, Joaquim Nabuco nutria convicções que não lhe permitiam compactuar plenamente, na qualidade tanto de poeta quanto de crítico, com o universo literário, regido por leis irresponsáveis.

Não teríamos, com tudo até aqui exposto neste capítulo, a explicação para o lugar dissemos acima - restrito e secundário de Camões dentro da produção intelectual nabucoana, bem como da sua aversão para com a atividade de crítica literária? Não teríamos, afinal, de endossar as palavras de Graça Aranha, melhor compreendendo-as, sobre o amigo mais velho:

[...] Joaquim Nabuco, dentro deste culto [a Camões], não se afina totalmente com a divindade. Jamais foi um camoniano no estrito sentido literário. Entre Camões e Nabuco não existiu o fluido íntimo, que tudo funde, e que identifica misteriosamente as essências dos seres. O seu culto é antes político, um ato da imaginação social, que the perdura como uma das forças motrizes do espírito. ${ }^{501}$

Mas essa conclusão não deixa de nos fazer deparar, ao fim e ao cabo, com a contradição de um autor que escreveu poemas na juventude, na maturidade e na velhice; de um autor que foi um dos fundadores da Academia Brasileira de Letras; ${ }^{502}$ publicou, durante o exercício diplomático na embaixada em Washington, o drama em francês L'option; e que, com sua obra-prima, Um estadista do império, de marcado caráter historiográfico, segundo Milton Carlos Costa, "soluciona o seu problema literário, encontra a sua maneira de ingressar e realizar-se na literatura". ${ }^{503}$ Contradição que igualmente verificamos no Joaquim Nabuco leitor de Camões: tão indisposto para com a crítica literária quanto, quer queira, quer não, intelectual que apresentou uma consciência crítica em matéria de literatura. Pois, se podemos

\footnotetext{
${ }^{501}$ ARANHA, 2003, p.27-28.

502 De qualquer forma, Joaquim Nabuco era favorável a uma composição de membros não apenas literatos, mas também políticos, cientistas e outras profissionais.

${ }^{503}$ COSTA, 2003, p.130.
} 
concordar com Carlos Daghlian, quando afirma que os estudos camonianos de Nabuco "são apreciações e não crítica das obras do poeta", ${ }^{504}$ não somos pela sua resolução da contradição, quando entende que, frente aos ataques à atividade crítica expressos tanto em Pensées détachés quanto nas conferências de 1908-09, o autor pernambucano teria escrito "uma apologia em vez de uma apreciação crítica dos poemas de Camões". ${ }^{505}$ Fosse em 1872, fosse em 1880, fosse ainda em 1908-09, ele jamais se isentou de levar em conta as deficiências ou o que enxergava como tais, na poesia camoniana, com seu ouro e seu cascalho.

Era Nabuco o leitor contraditório que, no ensaio de juventude, diante da imitação vigiliana n'Os Lusíadas, comparava Camões a "um condor que, posto nos Alpes e desconfiando do poder de seu vôo, não deixasse a região das aguias", ${ }^{506}$ para logo adiante dizer que "reconhece-se que o que elle [o quinhentista português] produz é distincto, original, novo, como uma creação".507 Era Nabuco o leitor contraditório que, nas conferências de 1908-09, recorria sistematicamente à comparação para situar o lugar de Camões na literatura, mas que ponderava nessas mesmas conferências: "To be able to weigh comparatively the inspiration of the most beautiful Canzones of Petrarca and Camoens would require a poet

\footnotetext{
504 DAGHLIAN, 1988, p.31.

505 DAGHLIAN, 1988, p.33.

506 NABUCO, 1872, p.180.
}

507 NABUCO, 1872, p.180. Importa comentar que Joaquim Nabuco veio a amadurecer sua concepção sobre originalidade e imitação, sobretudo no que se refere a Os Lusíadas. Nos parágrafos conclusivos de "The place of Camoens in literature", explica: "Camoens, no doubt, borrowed from Virgil [...]. No human mind was ever great enough to owe all to itself alone. [...] The law of genius is that of Molière: 'Je prends mon bien ou je le trouve;' only he must make it truly his own by a different and superior title, as Shakespeare so often did." (NABUCO(a), 1924, p.25) Tradução: "Não há dúvida de que Camões inspirou-se em Virgílio [...]. Nunca houve espírito humano suficientemente grande para tudo dever a si mesmo. [...]. A lei do gênio é a de Molière: 'Je prends mon bien où je le trouve'. É necessário, porém, em tais casos firmar o direito de posse com um título diferente e superior, a exemplo do que fez Shakespeare, não uma, senão repetidas vezes." (NABUCO, 1940, p.28-29). Certo aforismo de Pensées détachés igualmente testemunha o amadurecimento de Nabuco a respeito do assunto: "Ne recherchez pas l'originalité. Elle est plutôt, en général, un signe de médiocrité. On n'a le droit d'être original que sans le vouloir. Pour faire le génie il ne suffit pas l'originalité. Il faut que l'originalité soit l'expression de la pensée ou de l'aspiration universelle. L'originalité par elle seule est une qualité négative; il faut l'ajouter à une autre pour qu'elleait une valeur et celle-ci dépendra de la quantité positive qu'elle suivra." (NABUCO, 1906, p.109) Tradução nossa: "Não buscai a originalidade. Ela é antes, em geral, um sinal de mediocridade. Tem-se a penas o direito de ser original, sem o querer ser. Para se produzir um gênio, não basta originalidade. É necessário que a originalidade seja a expressão do pensamento ou da aspiração universal. A originalidade por si só é uma qualidade negativa; é necessário juntá-la a uma outra para que ela tenha um valor e faça parte da qualidade positiva que se Ihe atribui." 
superior to either, possessing not only the gifts of both, but the spirit of their two Ages and languages". 508

\section{2) Por que Camões?:}

Por que, afinal, Joaquim Nabuco elegeu Luís Vaz de Camões como assunto para o mais importante de sua atividade de crítico literário, ou antes, comentador literário? A pergunta, nesses termos, talvez soe besta, mas é pertinente, à medida que vamos conhecendo o conjunto da obra nabucoana, em todas as áreas abordadas e expressões. Mesmo que um Luís Viana Filho explique que o jovem pernambucano, em certo período do ano de 1872, "não tinha nada para fazer" e "gastou o tempo em ensaio sôbre os Lusíadas [...], quando ainda uma vez, faminto de celebridade e de pressa, se viu de braços cruzados diante do tempo, que voava",509 mesmo que um Antônio Carneiro Leão proponha que, pelo contrário, "Nabuco, desde a juventude, mostrou-se devoto de Os Lusíadas, fiel contrito do estro de Camões", 510 a pergunta - numa ou noutra perspectiva - permanece: por que Camões? Por que o primeiro embaixador do Brasil em solo norte-americano, sem os incentivos da efeméride de 1872 e 1880, escolheu o considerado nome maior da literatura portuguesa e não algum representante da literatura brasileira?

Nesta última parte do último capítulo de nossa tese, levantaremos algumas hipóteses que nos podem levar a compreender tal escolha de Joaquim Nabuco, embora - naturalmente não objetivem consistir numa explicação categórica, nem definitiva.

\footnotetext{
508 NABUCO(b), 1924, p.22. Tradução: "Para poder pesar em justa comparação o sopro inspirador das mais belas canções de Petrarca e de Camões, só um poeta superior aos dois, possuindo os dotes de um e outro, e, ademais, o espírito de suas duas épocas e dos seus dois idiomas". (NABUCO, 1940, p.56)

${ }^{509}$ FILHO, 1973, p.44.

${ }^{510}$ LEÃO, 1953, p.xxii.
} 
Os três momentos em que o autor de Balmaceda divulgou publicamente os resultados de suas leituras e reflexões camonianas - momentos esses distribuídos em fases distintas de sua vida: 1872, juventude; 1880, maturidade; 1908-09, velhice - revelam por si sós que ele admirava, se sentia bastante atraído pelo tema Camões. Porém, até ao ponto da devoção, da fé, como quer Carneiro Leão? O fato é que, em Minha formação, Joaquim Nabuco se limita a redigir uma única passagem na qual menciona o nome do quinhentista português. Passagem demasiado citada e célebre, onde o autor evoca a intenção juvenil de escrever e publicar o livro Camões e Os Lusíadas como exemplo de sua "atração do mundo".511 Desse modo, parece dar a entender que se circunscreve sua dedicação a Camões à motivação circunstancial (o ano do tricentenário da epopeia). Todavia, outro trecho do livro de 1900 é, a nosso ver, mais revelador. Trata-se de notícia sobre uma escalada qualitativa de leitura de poesia que encampa o autobiógrafo desde a juventude:

[...] tinha passado de Lamartine para Victor Hugo, o de Hernani quase exclusivamente, e de Victor Hugo para Musset, como devia depois passar de Musset para Shelley, de Shelley para Goethe, escala em que parei, mas onde não espero morrer, porque tenho diante de mim o Dante... o que não quer dizer que não tenha nos ouvidos a ressonância das grandes rimas novas de um Banville, e não admire o cinzelado dos fortes relevos de José Maria Heredia. ${ }^{512}$

A ausência de Camões na lista acima incomoda os que confiam na devoção camoniana de Nabuco. Seria o caso de sair-se com o que assegura Gilberto Freyre, notório estudioso do conterrâneo abolicionista?

"Está aí muito da minha vida", escreveu o próprio Nabuco ao prefaciar Minha formação. Mesmo assim talvez tenha se exagerado ao escrever "muito da minha vida". O que aí se revela é apenas uma complexa personalidade. "As

\footnotetext{
${ }^{511}$ Cf. NABUCO, 1981, p.42.

512 NABUCO, 1981, p.57.
} 
lacunas deste livro", também as reconhece Nabuco no mesmo prefácio. Mas sem especificá-las. A verdade é que são muitas do ponto-de-vista autobiográfico. ${ }^{513}$

Assim, nessa área de incompletude se encontraria a devoção camoniana que o próprio Joaquim Nabuco afirmaria cultivar, desde jovem, ao longo da vida, conforme lemos na sua primeira conferência pronunciada nos Estados Unidos acerca do poeta português?

Aquando da polêmica com José de Alencar, em 1875, Nabuco expressava opinião bem desfavorável a respeito da literatura do País (o que, tendo-se em mente a amizade com Machado de Assis, não parece derivar de mero ataque pessoal ao romancista de Iracema):

Para mim, o escritor brasileiro é um escritor de decadência. O Brasil não atravessa hoje uma época de florescência literária, quem o dissesse enganarse-ia muito. Os nossos tempos são de esterilidade, de mediocridade; a nossa produção não tem cotação nos grandes centros intelectuais do mundo. Virão talvez dias mais brilhantes, eu creio que hão de vir, só digo talvez porque nem todos os povos que atravessaram a cena da história distinguiram-se pela glória das letras. ${ }^{514}$

Mais de duas décadas após a polêmica, em artigo sobre o chileno Guilherme PuelmaTupper, coligido nos Escritos e discursos literários, de 1901, Nabuco parte da afirmação de que "as raças levam séculos a se formarem", para postular que

[...] nós, sul-americanos, que aspiramos no século XIX à vida superior, quisemos nascer antes $\mathrm{d}[\mathrm{o}]$ tempo e por isso ficamos todos falhos. Os melhores deixam um sulco; nenhum deixa uma obra. Puelma pertence a essa lista de insignes manqués, políticos, literários, filósofos, artistas, que compõem os nossos dicionários de biografia nacional. ${ }^{515}$

Em nota a outro texto que viria a integrar o mesmo livro, o discurso que proferiu na inauguração da Academia Brasileira de Letras, em julho de 1897, o secretário geral defendia a

\footnotetext{
513 FREYRE, 2010, p.183.

514 NABUCO in COUTINHO, 1965, p.217-218.

515 NABUCO, 1949, p.199.
} 
inferioridade literária de toda a América frente à Europa, de modo que: "Não se imagina literatura norte-americana mais rica do que a inglêsa; uma cultura chilena, colombiana, argentina, eclipsando a espanhola; nem - ignoro se há patriotas literários nessa reunião produção literária brasileira avassalando a portuguêsa." ${ }^{, 516}$ E também no corpo do próprio discurso, na presença de autor que já havia publicado As memórias póstumas de Brás Cubas e Quincas Borba, que "não tivemos ainda nosso livro nacional". ${ }^{517}$ Por outro lado, esse mesmo discurso continha passagem que marcava a transformação de pensamento do acadêmico de quase 50 anos de idade e o ensaísta de 23, que publicara Camões e Os Lusíadas e aí defendera consistir em "preconceito" o "dizer-se que devemos tornar-nos independentes de Portugal, litteraria, como nos tornámos politicamente":.518

\begin{abstract}
A principal questão, ao fundar-se uma Academia de Letras Brasileira, é se vamos tender à unidade literária de Portugal. Julguei sempre estéril a tentativa de criarmos uma literatura sôbre as tradições de raças que não tiveram nenhuma; sempre pensei que a literatura brasileira tinha que sair, principalmente, do nosso fundo europeu. Julgo, porém, outra utopia igual pensarmos que nos havemos de desenvolver literàriamente no mesmo sentido que Portugal, ou conjuntamente com êle, em tudo o que não depende do gênio da língua. $\mathrm{O}$ fato é que, falando a mesma língua, Portugal e o Brasil têm de futuro destinos literários tão profundamente divididos como são os seus destinos nacionais. Querer a unidade em tais condições seria um esfôrço perdido. Portugal, decerto, nunca tomaria nada essencial ao Brasil, e a verdade é que êle tem muito pouco, de primeira mão, que the queiramos tomar. ${ }^{519}$
\end{abstract}

Assim sendo, dado que o secretário geral da ABL já concebia que as literaturas brasileira e portuguesa estavam separadas, em consonância com a separação política entre

\footnotetext{
516 NABUCO, 1949, p.189.

517 NABUCO, 1949, p.186. Perante tudo isso, ficamos com a impressão de que Nabuco teria sido mais elegante que entusiasmado com o recebimento de exemplar e leitura de Dom Casmurro, comentado nestes termos em carta a Machado de Assis de 12 de junho de 1900: "Muito agradecido por suas felicitações e por seu livro que já tinha sorvido na fonte. V. sabe que sobre mim sua pena tem o poder de um condão e como V. me pode virar no que bem Ihe parecer [...]. (NABUCO in ARANHA, 2003, p.103) Em 1902 o também acadêmico Euclides da Cunha publicaria Os Sertões, que Nabuco qualifica de "bíblia da nacionalidade brasileira". Teria sido, finalmente, na opinião do pernambucano esse o "nosso livro nacional"?

518 NABUCO, 1872, p.15.

519 NABUCO, 1949, p.188.
} 
Brasil e Portugal, mesmo que Camões integre o muito pouco que os brasileiros quereriam tomar da literatura portuguesa, reforça-se ainda mais a estranheza na escolha da poesia camoniana como assunto das conferências que o dali a alguns anos embaixador do Brasil em Washington pronunciará. É certo, todavia, como vimos acima, que Joaquim Nabuco jamais teve em alta conta a literatura brasileira.

Descartada a literatura brasileira, pela sua generalizada baixa qualidade estética, o que mesmo os pendores nacionalistas não the perdoavam, ${ }^{520}$ na concepção de Joaquim Nabuco, este elegeria um poeta ou o poeta da literatura portuguesa, sobre cujas relações com a literatura do Brasil o autor pernambucano vai pensando diferentemente no Camões e Os Lusíadas, no discurso de 1880 e nas conferências de 1908-09. Não nos contentemos com a hipótese de que a literatura portuguesa, pela língua e pela história colonial, era a escolha mais legítima e natural, fora dos limites nacionais, para Nabuco, sendo Camões o maior poeta de Portugal. Nem sempre nosso interesse maior fareja o supra-sumo das coisas. Decerto devemos pensar na provável afinidade estética do abolicionista brasileiro com o quinhentista português.

Joaquim Nabuco foi perseguido continuamente pelo desejo frustrado de ser poeta. $\mathrm{Na}$ sua época e ainda hoje, a crítica literária jamais reconheceu efetivo valor nos seus versos, muitos em francês - os que constituem obras como Amour et Dieu, o drama escrito na juventude, revisado e publicado na velhice L'option, e Esclaves! versos franceses a Epiteto e outros versos em português, a exemplo dos sonetos inspirados na figura de Camões. Essa simples referência já insinua como o Nabuco poeta desprezava nacionalismos em literatura, e recorria a idioma no qual dizia pensar (o francês) e a temas estrangeiros. Embora alveje o regime escravocrata do Brasil em Esclaves!, para além de o poema ter sido composto na

\footnotetext{
520 Sendo assim, Nabuco pensaria algo muito próximo ao juízo de Antonio Candido acerca do assunto em prefácio à primeira edição de Formação da literatura brasileira, trecho que quase dispensa citação de tão conhecido: "Comparada às grandes, a nossa literatura é pobre e fraca", (CANDIDO, 2000, p.10.vol.I) sendo esta "galho secundário da portuguesa, por sua vez arbusto de segunda ordem no jardim das Musas". (CANDIDO, 2000. p.9.vol.I) Contudo, Nabuco não parece que subscreveria estas palavras de Candido: "Mas é ela, não outra, que nos exprime. Se não for amada, não revelará a sua mensagem; e se não a amarmos, ninguém o fará por nós." (CANDIDO, 2000, p.10. vol.I)
} 
língua de Racine, há aí muito de discussão universalizante do problema da escravidão. Em certa passagem do poema ("Oh le Brésil entier, c'est comme le Portique, -“), aproxima-se o Brasil ao Pórtico de Atenas, onde 'brillaient les combats sanglants et radieux / Des Amazones, sur le sol saint de l'Attique, / Des Vierges qui portaient la guerre aux Demi-dieux, -”.) ${ }^{521}$ O próprio destinatário dos versos sugere a inspiração e a motivação clássicas do texto. Pois, de fato, Joaquim Nabuco conciliou o cosmopolitismo, traduzido em Minha formação como "atração do mundo", à índole classicizante.

O que acima dissemos parece convergir com a análise de Ricardo Salles, em Joaquim Nabuco: um pensador do império, do livro Um estadista do império. É bom frisar de início que muitos estudiosos, alguns dos quais do porte de Gilberto Freyre, assinalam qualidades literárias em livros de Nabuco não propriamente literários. Na obra nabucoana como um todo, Freyre, rebatendo antiga crítica de um polícia gramatical, dirigida ao português supostamente errado do autor de $O$ abolicionismo, chega a fazer equiparar o legado estilístico de Nabuco para o Brasil ao de Eça de Queirós para Portugal. ${ }^{522}$ A esse propósito, um artigo publicado na revista $O$ eixo e a roda de 2010, dedicado a Joaquim Nabuco, propõe-se a ratificar o quilate literário de livros como Pensées détachées, do qual, segundo José Américo Miranda, o autor "soube muito defender sua pertença ao campo da literatura". 523

Um estadista do império foi escrito em momento de ostracismo político do autor, situação motivada ou imposta pela proclamação da República, em novembro de 1889 , e pela fidelidade monárquica desse que viera propondo reformas federalistas ao regime de D. Pedro II. Publicada completa ainda no século XIX, a obra colocava-se como manifesto monárquico e civilizatório contra a barbárie republicana, manifesto que, todavia, trazia a carga de desesperança em qualquer possibilidade de restauração.

\footnotetext{
${ }^{521}$ NABUCO, 1886, p.66.

${ }^{522}$ Cf. FREYRE, 2010, p.32.

${ }^{523}$ Cf. MIRANDA, 2010, p.54.
} 
Ricardo Salles interpreta Um estadista do império como obra clássica nas diversas acepções do termo. O pesquisador carioca opera, conjugadamente, com algumas das proposições definidoras de um clássico em conhecido texto de Italo Calvino, a concepção de Gadamer acerca de clássico e também com a condição de o livro de Nabuco, bem como outros produtos intelectuais de outros autores brasileiros, habitarem o entrelugar do ensaísmo e da literatura, caso de Os Sertões. Com efeito, a análise comparativa dessa obra de Euclides da Cunha integra a clave interpretativa de Ricardo Salles, que parte da compreensão de que clássico é 'tudo aquilo que transcende seu tempo e que, ao fazê-lo, tem a qualidade de transcender todos os tempos, de definir um padrão universal". ${ }^{524} \mathrm{Na}$ verdade, Salles procura esclarecer, de maneira conceptualmente sofisticada, ${ }^{525}$ as razões de Um estadista do império ser "quase unanimemente considerado um clássico da literatura política brasileira". 526 Duas razões seriam as principais: uma, de ordem estilística, marcada que é a narrativa do livro pela "retórica clássica", pelo "estilo literário",527 que vincava na "valorização do estilo clássico [que] predominava a partir do parnasianismo". ${ }^{528}$ Além disso, o pesquisador ressalta o "estilo particular do autor, seu esteticismo e seu gosto pelas frases cuidadosamente construídas, sua sintaxe afrancesada, como notou José Veríssimo". ${ }^{529}$ A outra razão residiria no fato de que "a obra de Nabuco realiza um projeto que dizia respeito a um passado ainda que não remoto, encerrado, um passado que essa mesma obra [Um estadista do império] retrataria como clássico por excelência". ${ }^{530}$ Em outras palavras, dentro do que Salles denomina de "projeto classicizante", Joaquim Nabuco associaria uma forma clássica a um assunto - o período

\footnotetext{
524 SALLES, 2002, p.181.

525 Dessa brilhante proposta analítica de Ricardo Salles só me incomoda o relativo incômodo do autor perante as poucas edições de Um estadista do império, como se o fato pudesse abalar a condição da obra nabucoana como clássico. Os interesses editoriais vinculam-se, como sabemos, mais a questões mercadológicas do que estéticas e intelectuais.

526 SALLES, 2002, p.182.

527 SALLES, 2002, p.186.

${ }^{528}$ SALLES, 2002, p.203.

${ }^{529}$ SALLES, 2003, p.203.

${ }^{530}$ SALLES, 2003, p.186.
} 
político em que viveu e atuou seu pai - assunto em decorrência de cuja "dimensão ímpar" e por se tratar de "uma época que se colocava para a nação brasileira como um momento fundamental e, ao mesmo tempo, perdido, de grandeza que nunca mais poderia ser igualada"531 - como clássico também. Assim sendo, estabelecer-se-ia, em Um estadista do império, não uma visão histórica de continuidade, mas de interrupção e conclusão de um período da história brasileira. Esse distanciamento entre o presente republicano e o passado monárquico teria permitido a Nabuco atingir em sua obra "uma dimensão de fruição estética". ${ }^{532}$ Mas a força clássica dessa época tal qual a apresenta Um estadista do império também se verificaria na sua condição de modelo em que se devia espelhar o presente, isso em conformidade com preceitos de obras não só literárias, mas também de cunho historiográfico enquadráveis no classicismo ${ }^{533}$ e na Antiguidade. Desse modo, "as normas clássicas de conduta política gestadas nessa época [da monarquia brasileira]"534 converteriam o passado em "mais que objeto de pura nostalgia", mas, numa integração com o presente, na medida em que se dava a "apontar rumos para o futuro". 535

Se, como quer Ricardo Salles, tanto Um estadista do império quanto Minha formação são realizações de um projeto classicizante e se as obras literárias - ou mais plenamente merecedoras de tal adjetivo - ostentam caráter profundamente clássico ou classicizante, temos aí outro veio de explicação para a escolha do abolicionista em tematizar Camões em seus trabalhos, de maneira tão especial. Afinal, mais do que um clássico da literatura lusófona, o poeta português era um autor clássico em termos estético-cronológicos. Cumpre observar que Nabuco amadureceu intelectualmente numa época em que a cultura brasileira (a que ditava e irradiava o Rio de Janeiro, pelo menos) incentivava simpatias e identificações com a arte, a

\footnotetext{
531 SALLES, 2002, p.199.

532 SALLES, 2002, p.199.

533 Caso d'Os Lusíadas, no qual a história de Portugal serviria de lições, dentro do preceito horacioano de docere cum delectate, para a sociedade e o governo portugueses.

534 SALLES, 2002, p.204.

535 SALLES, 2002, p.205.
} 
literatura, tudo que fosse ou cheirasse a classicismo. O grande produto literário desse contexto foi decerto o parnasianismo, aliás nomeado (por maioria ideológica) escola oficial das letras brasileiras.

Na segunda metade do século XIX, o universalismo de coloração classicizante pode ser verificado na presença de Camões e da autoridade literária e linguística portuguesa que muitos brasileiros acataram. Olavo Bilac, corifeu parnasiano, escreverá o soneto 'Língua portuguesa" em severa obediência à gramática lusitana e mencionando Camões, em sugestão de este ser o maior poeta da "inculta e bela", e Lima Barreto, aliás, ferrenho crítico do parnasianismo, acusará em carta a Austregésilo de Ataíde, em 1921, muito significativamente, Machado de Assis de escrever "com medo do Castilho".536 António Feliciano de Castilho, afinal, com seu Tratado de versificação (1855), modificou a concepção do verso em língua portuguesa também no Brasil, cujos poetas, dentre os quais Machado de Assis, abandonam o sistema espanhol, vigente, de contagem métrica de um verso (considerando-se uma sîlaba após a última tônica) e adotam a concepção francesa, segundo a qual se contava até a última sillaba tônica do verso, concepção que, afinal, saiu vitoriosa tanto em Portugal quanto no Brasil, conforme se pode atestar no conjunto dos tratados de versificação de lá para cá publicados. ${ }^{537}$ Tal peso ou influência portuguesa na cena cultural oitocentista brasileira levanos a pensar no diálogo estabelecido entre a geração de 70 d'aquém e d'além-mar. Pois, conforme observamos no Capítulo 1 de nosso trabalho, a poesia camoniana esteve presente no horizonte de reflexão tanto de Teófilo Braga, Oliveira Martins, Antero de Quental, Eça de Queirós, Ramalho Ortigão, quanto de Joaquim Nabuco, Machado de Assis, Miguel de Lemos, Teixeira Mendes, dentre outros.

\footnotetext{
${ }^{536}$ Cf. BARRETO, 1956, p.257. vol.XVII.

537 Remetemos o leitor ao artigo que escrevemos em coautoria com o professor José Américo Miranda "O alexandrino português" In O eixo e a roda, Belo Horizonte, v. 14, n. 1, p.15-28, jan-jun. 2007.
} 
De início, cabe dizer que os brasileiros da pequeníssima percentagem alfabetizada e leitora liam bastante Eça de Queirós, Ramalho Ortigão, Camilo Castelo Branco, Pinheiro Chagas e outros autores portugueses do século XIX. O relativamente grande número de leitores que Eça de Queirós contava no Brasil, a ponto de "editores brasileiros [tomarem] a liberdade de publicar os seus romances sem sua permissão", e o sucesso de O primo Basílio foi de tal ordem no País, que a obra chegou a ser adaptada para o palco carioca no mesmo ano de publicação do romance (1878). ${ }^{538}$ Com efeito, sobretudo no que toca ao escritor d'Os Maias, a influência da literatura portuguesa foi considerável. Muitos escritores nacionais, mais afeitos às diretrizes realistas e naturalistas, a exemplo de Aluízio Azevedo, reverenciaram-no como modelo e mestre. ${ }^{539}$ Mas devemos salientar também a presença de outros portugueses na cena intelectual da segunda metade do século XIX brasileiro: Oliveira Martins, cujo "O Brasil e as colônias portuguesas [...] [de 1880] foi uma sensação" Teófilo Braga, que "era talvez o nome mais citado entre 'cientificistas' e 'positivistas' [brasileiros]". ${ }^{541}$ Alguns dos que pertenceram à chamada a posteriori Geração de 70 brasileira estabeleceram mesmo relações de amizade e colaboração com integrantes da Geração de 70 portuguesa, conforme noticia Beatriz Berrini:

\footnotetext{
538 VIEIRA, 1991, p.93.

539 "[...] a esse sim é que se pode chamar Mestre", disse o romancista de $O$ cortiço em carta datada de abril de 1904. (apud MOISÉS in COSTA E SILVA, 2002, p.200) Se o entusiasmo pela obra eciana resultou nos bons romances de Aluízio Azevedo, por outro lado, Monteiro Lobato, em prefácio de No silêncio..., livro de Borges Neto, a 1918, escreverá: “...quando Eça, novidade, grassava no Brasil inteiro, a imitação inconsciente produziu os mais desastrosos efeitos. Eça matou muita vocação promissora. Fêz pálidos satélites de talentos capazes de luz própria. Deu nascimento a uma pasticharia mecânica, donde todo tipo gordo saía molda do pelo Consel heiro [Acácio] e as mulheres eram Luísas, os boêmios Egas, virando o autor simples papel carbono de decalque." (apud MARTINS, 1969, p.23-24) Nélson Werneck Sodré, em O naturalismo no Brasil, aponta em toda essa receptividade brasileira muito de "incompreensão a respeito da significação e do conteúdo do naturalismo e particularmente da obra de Eça de Queiroz", pois "aquilo que ficou na memória geral foi, destacadamente, a galeria de tipos" e não "a sua ironia, a sua graça, o seu sarcasmo, a sua linguagem, a sua exatidão", além da "descrição da sociedade, de uma sociedade em decomposição, a minuciosa análise da lenta fermentação que nela vinha ocorrendo". (SODRÉ, 1992, p.167)

540 ALONSO, 2002, p.174.

${ }^{541}$ ALONSO, 2002, p.175.
} 
Se Eduardo Prado necessita comprar papel para seus jornais recorre a António Feijó e the pede informações comerciais a respeito dos fornecedores suecos; por outro lado, Eça vai recorrer a Eduardo Prado para averiguar a possibilidade de adquirir na Inglaterra clichês para a publicação da revista que tem em mente. Nabuco por seu lado quer saber por onde anda Queiroz, que estimaria encontrar no Sul da França, enquanto Rio Branco dá indicações a Ramalho a respeito de mapas que se encontram em Madrid e que lhe são necessários para vencer o processo contra a Argentina a respeito dos limites do Sul do Brasil; e ainda: não se hospedava Batalha Reis com sua filha, frequentemente, na casa londrina de Joaquim Nabuco $[\ldots] ?^{542}$

Nos diários de Joaquim Nabuco também se encontram diversas anotações que comprovam essa ligação entre a Geração de 70 portuguesa e brasileira. Nos primeiros dias de janeiro de 1881, quando o abolicionista estava em Lisboa, anota ter jantado com Bordalo Pinheiro, Ramalho Ortigão, Eduardo Coelho, Júlio César Machado, Eduardo Garrido, Brito Aranha e Augusto Rosa, ter visitado Teófilo Braga, na companhia de Carvalho Monteiro e outra vez jantado na casa de Ramalho Ortigão na companhia de Oliveira Martins. ${ }^{543}$

Dito tudo isso, quanto às nossas hipóteses relativas às razões da escolha de Camões por parte de Joaquim Nabuco para o que se afirmou como o mais importante de sua crítica (ou, como prefere dizer Luiz Costa Lima, tentativa de crítica) literária, podemos acrescentar o fato de a poesia camoniana e o próprio poeta quinhentista terem-se tornado um dos valores fundamentais do mundo luso-brasileiro, e também objeto de notável interesse de estudiosos europeus, a exemplo de Alexander von Humboldt, Edgar Quinet, Friedrich Schlegel, Wilhelm

\footnotetext{
542 BERRINI, 2003, p.56.

${ }^{543}$ Cf. NABUCO, 2006, p.222. Por outro la do, é curioso notar que dois dos mais importantes críticos literários do Brasil da época, Araripe Júnior e Sílvio Romero, nutrissem patriótica aversão à literatura portuguesa em geral, engajados eles em definir a identidade nacional de nossa literatura, supostamente tão autônoma da exmetrópole quanto politicamente o era a ex-colônia. Desconsiderando o valor da literatura portuguesa, da qual "excluído Camões nada há [...] que nos possa causar inveja", (ARARIPE JÚNIOR, 1977, p.376) segundo Araripe esclarece das opiniões de Romero, este, em artigo que compõe sua História da literatura brasileira, considera com orgulho nacionalista que, em Álvares de Azevedo, "melhor do que em nenhum outro distingo eu os dois sintomas: 10 é ele um produto local, indígena, filho de um meio intelectual, de uma academia brasileira; 20 arranca-nos de uma vez da influência exclusiva portuguesa", (ROMERO in AZEVEDO, 2000, p.27) sintomas que se confirmariam, no âmbito político, com Eusébio de Queirós, Zacarias, Joaquim Nabuco, Rio de Branco e, na literatura, com Bernardo Guimarães, Junqueira Freire, Joaquim Manuel de Macedo e outros. (ROMERO in AZEVEDO, 2000, p.27-28)
} 
Storck, Carolina Michaëlis de Vasconcelos, conforme observamos no Capítulo 1 deste nosso trabalho.

E, assim, ficamos com estes vetores de influência: 1) o contexto de alcance lusobrasileiro e ocidental, em que Camões se tornou objeto de reverência cultural e de canonização cívico-literária; 2) o vínculo, o diálogo estreito entre integrantes da Geração de 70 brasileira com Geração de 70 portuguesa, juntamente ao fato de a literatura portuguesa ter tido bastante público e ressonância no meio literário brasileiro na época; 3) a concepção classicizante de Nabuco como homem de letras, o que atestam suas obras tanto literárias, a exemplo de L'option, e ensaísticas, a exemplo de Um estadista do império; 4) a compreensão de que a literatura brasileira, bem como todas as americanas, eram inferiores às europeias, e o Brasil não ter produzido ainda seu livro nacional, em concordância com o diagnóstico de que as eminências políticas e intelectuais da América do Sul seriam todos falhos, nenhum deles deixando uma obra digna de ter cotação nos grandes centros intelectuais do mundo.

Apontamos, na primeira parte deste capítulo, para as contradições que marcam a relação de Joaquim Nabuco com a obra de Camões. De um lado, o pernambucano praticou, durante toda sua vida intelectualmente madura, a poesia, tendo publicado numerosos versos, em português e francês, e foi seduzido, nos últimos anos de existência, a fazer publicar o drama L'option, obra escrita na juventude e revisada posteriormente; de outro lado, expressou mais de uma vez sua reserva quanto à poesia, à ficção - o que Luiz Costa Lima atribui ao trauma da escravidão, que partiria, conforme Nabuco alerta em $O$ abolicionismo, do fato de que as leis brasileiras, desde o jurisconsulto Teixeira de Freitas, que as consolidaria em 1855, “ignora[vam] a mera existência do trabalho escravo", fazendo "com que o termo 'ficção' se esgotasse na sinonímia de falsidade e mentira". ${ }^{54}$ A proposta interpretativa do teórico maranhense, como vimos, se revela mais convincente, face ao trecho do diário em que

544 LIMA, 2002, p.347. 
Nabuco compara o poeta a um criminoso que se absolve a si mesmo. Também, de um lado, temos um Nabuco interessado na atividade de crítica literária, sobretudo em torno de Camões; mas, de outro, principalmente em Pensées détachés e nas conferências de 1908-09, dedicado a desqualificar sistematicamente essa mesma atividade.

Em meio às nossas hipóteses com que procuramos compreender o que teria motivado Joaquim Nabuco a eleger Camões nos propósitos já aqui explicitados, confrontamo-nos com outras contradições: a de um autor que declarava admirar o quinhentista português nos estudos camonianos, mas que não se referiu a esse poeta em outras obras, ao exemplo contundente de Minha formação, de modo a nos convencer dessa sua admiração; a de um autor que, a partir do século XIX, está convicto de que a literatura brasileira deve seguir um caminho próprio, sem unidade com a literatura portuguesa, mas um autor que escolhia Camões para fomentar o interesse norte-americano pelo Brasil, nas conferências que pronunciará como embaixador deste País em Washington.

Esse estigma da contradição, verificável em distintos aspectos, nos textos que Joaquim Nabuco escreveu sobre o autor d'Os Lusíadas talvez constitua, paradoxalmente, a coerência interna de toda sua obra escrita e realizações políticas - passíveis de ser interpretadas por uns como as de um reformador radical e por outros como as de um conservador reacionário. 
CONCLUSÃO 
Foi válido termos dividido a recepção nabucoana de Camões em dois períodos abordados nos Capítulos 2 e 3: o primeiro período a concernir ao ensaio de 1872 e ao discurso de 1880; o segundo, às três conferências de 1908-09. Mais do que referir-se a dois séculos distintos, trata-se de duas fases diferentes da vida de Joaquim Nabuco, engajado em cada uma numa causa que comprometeu, em menor ou maior profundidade, a significação de seus textos camonianos.

Com efeito, a questão da escravidão, que interessou Joaquim Nabuco muito cedo, atingiu os seus dois primeiros trabalhos sobre o poeta quinhentista. Em Camões e Os Lusíadas, o regime escravocrata figura como um dos fatores que impediriam a literatura brasileira de conquistar sua autonomia frente à portuguesa. E o jovem ensaísta ainda lamentava a suposta apologia à escravidão na epopeia. Oito anos depois, Camões passa a ser, na visão do então deputado, espécie de abolicionista avant-la-lettre. Já no século XX, na condição de embaixador do Brasil em Washington, Nabuco está de mãos dadas com o panamericanismo monroísta e é, em nome dessa doutrina de política externa, que pronuncia suas três conferências sobre o vate lusitano.

Seja como for, o monroísmo contextualiza muito melhor "The place of Camoens in literature", "Camoens, the lyric poet" e "The Lusiads as epic of love" do que o abolicionismo o ensaio de 1872 e o discurso de 1880. Isso porque esses dois produtos da admiração de Nabuco por Camões foram motivados, em grande medida, pelo tricentenário de publicação d'Os Lusíadas e pelo da morte do poeta português, respectivamente. Em 1908 e 09, sem o incentivo da efeméride, são os objetivos diplomáticos do pernambucano nos Estados Unidos que o impelem a abordar, novamente, o assunto.

A importância de Camões para a literatura oitocentista é assinalável, e não apenas considerando-se os limites luso-brasileiros. Pré-românticos e românticos europeus, como 
Ludwig Tieck, Chateaubrind, os irmãos Schlegel, Lord Byron ficaram sensibilizados com o patriotismo expresso n'Os Lusíadas, com a alta voltagem amorosa nos sonetos e com a qualidade poética tanto na lírica quanto na épica camonianas.

$\mathrm{Na}$ primeira metade do século XIX, Almeida Garrett transformou o compatriota quinhentista no símbolo maior da pátria e Os Lusíadas na bíblia da nacionalidade portuguesa, num processo ao qual se associaram romantismo, liberalismo, saudade, tudo isso condicionado pelo imperativo cívico que a consolidação da nação como novo paradigma político-cultural ditava aos escritores. $\mathrm{Na}$ segunda metade do século XIX, Teófilo Braga sente-se herdeiro desse legado garrettiano. Não se atém, todavia, a pesquisar a vida e a obra de Camões, com isso se tornando o maior camonólogo português do oitocentos, mas também se empenha em fazer do tricentenário de 1880 uma cerimônia de resgate do orgulho patriótico e, ao mesmo tempo, propaganda antimonárquica e republicana.

Conquanto não comungassem das crenças políticas e positivistas teofilianas, tampouco aprovassem a apropriação de Camões nas comemorações de 1880 realizada pelo futuro primeiro presidente da república portuguesa, Oliveira Martins e Antero de Quental (mas principalmente Oliveira Martins) ratificaram a importância do autor d'Os Lusíadas para Portugal. As sérias pesquisas camonianas dos alemães Wilhelm Storck e Carolina Michaëlis de Vasconcelos acabariam por endossar ainda mais a canonização do cantor de "Alma minha gentil que te partiste" nos limites lusófonos.

Os brasileiros Álvares de Azevedo, Casimiro de Abreu, Machado de Assis, Miguel Lemos e Afrânio Peixoto somente constituem mínima amostra de como, na ex-colônia americana, Camões foi bastante reverenciado, seja nos moldes de uma recepção crítica, seja nos de uma recepção criativa. $O$ que se destaca nesse amplo panorama luso-brasileiro oitocentista é, de qualquer forma, a questão da nacionalidade. 
E a questão da nacionalidade pode ser entendida como uma das chaves de interpretação dos textos que Joaquim Nabuco dedicou a Camões. No ensaio de 1872, o autor pernambucano era indiferente ao cinquentenário de proclamação de nossa independência, e reivindicava o poeta português como assunto nacional. Homenageando o terceiro centenário de publicação d'Os Lusíadas, nesse volume, Nabuco não considerava a literatura brasileira independente da portuguesa, argumentando que o indianismo não poderia propor-se na condição de autêntica literatura do Brasil, pois a estrutura de nossa sociedade devíamos antes à Europa do que aos índios. Ademais, o regime escravocrata atestaria o resquício colonial do País. E ainda o jovem ensaísta tinha por preconceito o anseio de se dar o grito às margens do Ipiranga no jardim das musas. Desse modo, contra o romantismo indianista, expressão simbólica do Segundo Reinado, Joaquim Nabuco brandia o classicismo camoniano, postura que se reafirma - involuntária no princípio, de maneira mais programática no seu desenvolvimento - na polêmica que travaria com José de Alencar, em 1875, e se enquadra numa outra, de longeva duração e repercussão, que Afrânio Coutinho batizou de "polêmica da Minerva Fluminense". Em suma, Nabuco não estava sozinho na sua defesa da unidade das literaturas brasileira e portuguesa, mas, em diferentes aspectos argumentativos, na companhia de autores, tanto da primeira quanto da segunda metade do século XIX, como Álvares de Azevedo, Machado de Assis e, até certa fase, José Veríssimo.

Em 1880, ocasião de outro centenário (este muito mais comemorado, aquém e alémmar do que o de 1872), o então deputado pernambucano discursava sobre o vate quinhentista, em evento organizado pelo Real Gabinete Português de Leitura do Rio de Janeiro. Era mais uma oportunidade de dar novo aperto no laço cultural entre Portugal e Brasil. A afirmação da identidade nacional pautava-se agora, com mais força, não na idealização do índio, mas no iberismo - isto é - na revisão da história do Brasil colônia, e também no olhar voltado para o escravo, tradicionalmente à margem da sociedade, da literatura, das leis, e no crescente 
movimento abolicionista. Nabuco estava, portanto, em perfeita sintonia com o ambiente daquelas comemorações, que reproduziam a adesão ampla de nomes ilustres da política e da intelectualidade que se dava em Portugal. No entanto, no discurso, Joaquim Nabuco não mais encampa a defesa de unidade entre as literaturas brasileira e portuguesa, tal qual fizera em 1872. Camões, em 1880, ensejava uma festa da nacionalidade lusitana, na qual os brasileiros deviam participar por fazerem parte da mesma família. O passado colonial, a permanência da dinastia bragantina no governo do País, a residência aqui de numerosos emigrantes portugueses eram os indicativos dessa proximidade de sangue entre Portugal e Brasil. Quanto a Os Lusíadas, a epopeia deixava de ser a obra-prima de uma literatura que é nossa para nos pertencer também um pouco.

$\mathrm{O}$ que proferia Joaquim Nabuco naquela noite de 10 de junho respondia aos ataques de integrantes da comunidade portuguesa residente no Rio de Janeiro, insatisfeitos com o fato de um brasileiro ter sido convidado a ser o orador oficial de uma festa de cunho patriótico. Em 1872 e 1880, Nabuco apresentou, contra brasileiros lusófobos e portugueses xenófobos, um Camões, acima de tudo, luso-brasileiro.

Nos anos finais da primeira década do século XX, a causa abolicionista havia muito estava ganha, a república já se tornara o regime de governo do Brasil. Joaquim Nabuco enfrentara fase bastante difícil, de 1889 até o início do novecentos, fiel que seria durante tal período à monarquia. Ao aceitar o cargo de embaixador em Washington, adere oficial e definitivamente ao barrete frígio, e se dispõe a executar a aproximação do país que representava com os EUA, segundo o que entendia do pan-americanismo monroísta. Este, afinal, à revelia das demais nações da América latina, foi seu principal objetivo como panamericanista, de modo a precisarmos empregar o termo ao caso nabucoano com cautela. As três conferências acerca de Camões, que pronuncia em universidades norte-americanas, têm 
sido, de fato, compreendidas como à serviço do projeto diplomático do autor de Um estadista do império.

Contudo, em se tratando de um fundador e secretário geral da Academia Brasileira de Letras, de alguém convencido àquela altura da necessidade de os escritores nacionais tomarem rumos independentes dos da literatura da ex-metrópole, a escolha de Camões era algo inusitado. Fosse como fosse, Nabuco procurou destacar, com essas conferências, pontos de identificação entre a poesia camoniana e a cultura norte-americana e, além disso, singularizar o Brasil dentro da América latina. Na verdade, o embaixador, tendo em vista o desprestígio da ex-colônia portuguesa em relação às ex-colônias espanholas, atribuía significativamente a Os Lusíadas o mesmo valor cultural de todo o conjunto da grande arte, plástica e literária, da Espanha, num propósito de valorizar o país que dera origem ao Brasil. Temos, pois, nesses anos de 1908-09, um Camões pan-americanista, mas de um panamericanismo que privilegiava o estreitamento de laços Brasil-EUA, em certo desfavor do restante da América espanhola.

Decerto Joaquim Nabuco jamais foi um leitor abalizado da poesia camoniana, tampouco um crítico literário no rigor do termo, mesmo para os padrões oitocentistas. De qualquer forma, seus estudos camonianos comprometeram-se com o que aqui denominamos de estigma da contradição. Sobretudo a partir de Pensées détachés, livro publicado em 1906, Nabuco ataca a atividade da crítica literária, desqualificando-a, num ranço que nos parece advir dos resquícios de concepção romântica, aliás, presentes nos seus trabalhos de 1872, 1880 e 1908-09. Também o platonismo nabucoano, bem aclimatado no contexto brasileiro bastante adverso ao pensamento reflexivo, e respaldado em tradição ocidental de se considerar o crítico inferior e vampirizador do que escreve o poeta, parecia pressupor que a obra literária consistia numa cópia da ideia que nunca se concretizava plenamente na escrita, ao passo que o 
texto crítico era seu nefasto simulacro. Outrossim, conforme compreensão certamente limitada desta atividade, o crítico era um presunçoso misto de juiz e legislador. Entretanto, que foi o Nabuco leitor de Camões senão, posto que não abalizado, alguém que tentava produzir crítica literária?

O estigma da contradição também se verifica na relação dúbia do autor pernambucano com a própria literatura: ao mesmo tempo em que escrevia textos literários, e até mesmo obras como Minha formação e Um estadista do império têm sido acolhidas como literárias, Nabuco manteve certa reserva diante da literatura, considerando a ficção criminosamente alheia à realidade.

E quando procuramos responder a por que Joaquim Nabuco escolheu Camões para tema de seus mais importantes estudos literários, deparamo-nos com o mesmo estigma da contradição. A canonização luso-brasileira e europeia do poeta no decorrer do século XIX; a pouca conta em que tinha o autor pernambucano a literatura brasileira; a presença intelectual acentuada de Portugal na ex-colônia em todo o oitocentos; e a índole classicizante de Nabuco foram nossas hipóteses para tentar explicar aquela escolha. Mas a admiração por Camões se choca com sua ausência em textos não propriamente dedicados ao tema, mas que proporcionavam oportunidade para o autor ratificar sua admiração pelo quinhentista português.

Se Camões e Os Lusíadas, o discurso de 1880 e as três conferências de 1908-09 pouco ou nada pesam na camonologia oitocentista e foi desprezada quase totalmente pela novecentista e ainda hoje não alcançou real reconhecimento, pelo menos é inegável que esses trabalhos contribuem para a maior compreensão das práticas culturais do Brasil da década de 1870 até princípios do século XX, além de iluminar o sentido de outras obras de Joaquim Nabuco mais favorecidas pela posteridade. 


\section{Bibliografia:}

ABREU, Casimiro. Poesias completas. Rio de Janeiro: Ediouro, [s.d.].

ALONSO, Angela. Idéias em movimento: a geração 1870 na crise do Brasil-Império. Rio de Janeiro: Paz e Terra, 2002.

Joaquim Nabuco: os salões e as ruas. Perfis Brasileiros. São Paulo: Companhia das Letras, 2007.

ANDRADE, Olímpio de Souza. Joaquim Nabuco e o pan-americanismo. São Paulo: Companhia Editora Nacional, 1950.

ARANHA, Graça (org.) Machado de Assis e Joaquim Nabuco: Correspondência. Rio de Janeiro: Topbooks, 2003.

ARARIPE JÚNIOR. Teoria, crítica e história literária. Seleção e apresentação de Alfredo Bosi. São Paulo: EDUSP, 1977.

ASSIS, Machado de. Dom Casmurro. Rio de Janeiro: Globo, 1997.

- "Notícia da atual literatura brasileira: Instinto de nacionalidade". In: CANDIDO,

Antonio; CASTELLO, José Aderaldo. Presença da literatura brasileira II: do romantismo ao simbolismo. São Paulo: Difusão Européia do Livro, 1968. pp.136-141.

. “Tu, só tu, puro amor”. In: Theatro. Rio de Janeiro; São Paulo; Porto Alegre: W. M. Jackson, 1938. pp. 263-308.

ASSUNÇÃO, Maria. O essencial sobre Carolina Michaëlis de Vasconcellos. Lisboa: Incm, 1986.

AZEVEDO, Álvares de. Obras completas. Rio de Janeiro: Nova Aguilar, 2000.

BALAKRISHNAN, Gopal (org.). Um mapa da questão nacional. Rio de Janeiro: Contraponto, 2000.

BAPTISTA, Abel Barros. "O cânone como formação: a teoria da literatura brasileira de Antonio Candido". In: O livro agreste. Campinas: Unicamp, 2005. pp. 41-80.

BARRETO, Lima. Obras. Rio de Janeiro: Brasiliense, 1956. vol. XVI.

Triste fim de Policarpo Quaresma. 2a ed. São Paulo; Rio de Janeiro: Record, 1998.

BENJAMIN, Walter. O conceito de crítica de arte no romantismo alemão. $3^{\mathrm{a}}$ ed. São Paulo: Iluminuras, 2002.

BERARDINELLI, Cleonice. Estudos camonianos. Rio de Janeiro: MEC; UFF, 1973. 
BERRINI, Beatriz. Brasil e Portugal: a geração de 70. Porto: Campo das Letras, 2003.

BILAC, Olavo. Poesias. São Paulo: Martins Fontes, 1997.

BOCAGE, M. M. Barbosa du Bocage. Sonetos. Rio de Janeiro; Belo Horizonte: Garnier, 1994.

BORGES, Jorge Luis. Destino y obra de Camoens. Buenos Aires: Embajada de Portugal, 2001.

BRAGA, Teófilo. História da literatura portuguesa: Renascença. $3^{\text {a }}$ ed. Lisboa: Imprensa Nacional - Casa da Moeda, 2005. Vol 2.

O sentimento nacional. Porto: Lugan \& Genelioux, 1891.

BRAGA, Teophilo. Luiz de Camões (escorço biographico). In: CAMÕES, Luiz de. Sonetos: $1^{\text {a }}$ parte. Lisboa: A Educadora, 1913. pp. 5-26.

CABRAL, Alexandre. "A estranha participação de Camilo Castelo Branco nas comemorações camonianas de 1880". In: Revista Camoniana. Centro de Estudos Portugueses. 2a série, vol II. São Paulo, USP, 1979. pp.7-20.

. "Comemorações camonianas de 1880". In: Notas oitocentistas. Lisboa: Plátano, 1973. pp.91-256.

CAMÕES, Luís de. Os Lusíadas. Porto: Porto Editora, 1997.

CANDIDO, Antonio. "A educação pela noite”. In: A educação pela noite e outros ensaios. $2^{\text {a }}$ ed. São Paulo Ática, 1989. pp.10-22.

Formação da literatura brasileira: momentos decisivos. 9a ed. Belo Horizonte; Rio de Janeiro: Itatiaia, 2000. vol.I.

Formação da literatura brasileira: momentos decisivos. 9a ed. Belo Horizonte; Rio de Janeiro: Itatiaia, 2000. vol.II.

. "Os brasileiros e a nossa América". In: Recortes. Rio de Janeiro: Ouro sobre Azul, 2004. pp.143-155.

CARVALHO, José Murilo de. A formação das almas: o imaginário da república no Brasil. São Paulo: Companhia das Letras, 2011.

CARVALHO E SILVA, Maximiano. "Joaquim Nabuco e as comemorações camonianas de 1880". In: NABUCO, Joaquim. Camões: discurso pronunciado a 10 de junho de 1880 por parte do Gabinete Português de Leitura. Rio de Janeiro: Biblioteca Nacional, 1980. pp.7-26.

CASTELO BRANCO, Camilo. Luís de Camões: apontamentos biográficos. In: GARRETT, Almeida. Obras. Porto: Lello \& Irmão, 1963. vol.II. pp.271-292.

Obras completas. Porto: Lello \& Irmão, 1989. vol.XI. 
CATÁLOGO DA EXPOSIÇÃO CAMONEANA: realizada pela Bibliotheca Nacional do Rio de Janeiro a 10 de Junho de 1880 por ocasião do Centenario de Camões. Rio de Janeiro: Typographia Nacional, 1880.

CIDADE, Hernâni. Luís de Camões: o lírico. $3^{\mathrm{a}}$ ed. Lisboa: Bertrand, 1967. vol I. Luís de Camões: o épico. $3^{\mathrm{a}}$ ed. Lisboa: Bertrand, 1968. vol II.

COELHO, A. do Prado. Teófilo Braga. Lisboa: Eduardo Simões, 1921.

CORTESÃO, Jaime. Camões e o descobrimento do mundo. Lisboa: Cadernos da Seara Nova, 1944.

COSTA, Milton Carlos. Joaquim Nabuco entre a política e a história. São Paulo: Anablume, 2003.

COUTINHO, Afrânio (organização e introdução). A polêmica Alencar-Nabuco. Rio de Janeiro: Tempo Brasileiro, 1965.

A tradição afortunada: o espírito de nacionalidade na crítica brasileira. Rio de Janeiro: José Olympio; Edusp, 1968.

Conceito de literatura brasileira. In: Conceito de literatura brasileira. Rio de Janeiro: Ediouro, [s.d.]. pp. 9-86.

COUTINHO, Afrânio. Introdução à Literatura Brasileira. Rio de Janeiro: Livraria São José, 1968.

CUNHA, Carlos Manuel Ferreira da. A construção do discurso da história literária na literatura portuguesa do século XIX. Braga: Universidade do Minho / Centro de Estudos Humanísticos, 2002.

DAGHLIAN, Carlos. Os discursos americanos de Joaquim Nabuco. Recife: Massangana, 1988.

DIAS, J. S. da Silva. Camões no Portugal de quinhentos. Lisboa: Instituto de Cultura e Língua Portuguesa; Ministério da Educação, 1981.

DÓRIA, A. Álvaro. "Oliveira Martins e Camões". In: Revista Camoniana. Centro de Estudos Portugueses. 2a série, vol II. São Paulo, USP, 1979. pp.21-63.

DASILVA, Xosé Manuel. "Carolina Michaëlis e a inauguração da modernidade dos estudos camonianos”. Revista Línguas e Literaturas. Porto, XVIII, 2001. pp.93-106.

DRUMOND, Adriano Lima. "A binomia de duas almas irmanadas: Bocage na obra de Álvares de Azevedo". In: Revista Crioula. no 5, maio, 2009. Disponível em: << http://www.fflch.usp.br/dlcv/revistas/crioula/edicao/05/Artigos\%20e\%20Ensaios\%20$\% 20$ Adriano\%20Drumond.pdf $\gg>$

EHRHARDT, Marion. “A projeção de Os Lusíadas nas letras alemãs”. In: Panorama: revista portuguesa de arte e turismo. $\mathrm{n}^{\text {os }} 42 / 43$, IV série, setembro de 1972. pp.55-62. 
ELIA, Hamilton. Camões e a literatura brasileira. Rio de Janeiro: MEC; UFF, 1973.

ELIOT, T. S. Selected Essays. Glasgow: University Press Glasgow, 1951.

FERREIRA, Alberto e MARINHO, Maria José. Bom senso e bom gosto: a Questão Coimbrã (1865/1866). Lisboa: Imprensa Nacional-Casa da Moeda, 1985. vol.I.

FRANÇA, José-Augusto. O romantismo em Portugal: estudos de factos socioculturais. $3^{\text {a }}$ ed. Lisboa: Livros Horizonte, 1999.

FRÈCHES, Claude-Henri. "Camões et la France. De |Voltaire a Edgar Quinet".. In: Panorama: revista portuguesa de arte e turismo. $n^{\text {os }} 42 / 43$, IV série, setembro de 1972. pp.4854.

GARRETT, Almeida. Obras. Porto: Lello \& Irmão, 1963. vol. I.

Obras. Porto: Lello \& Irmão, 1963. vol. II.

GOUVÊA, Fernando da Cruz. Joaquim Nabuco entre a monarquia e a república. Recife: Fundação Joaquim Nabuco; Massangana, 1989.

HANSEN, João Adolfo. A máquina do mundo. In: NOVAES, Adauto (org.). Poetas que pensaram o mundo. São Paulo: Companhia das Letras, 2005. pp.157-197.

HERCUlANO, Alexandre. "Carta V”. In: NEVES, Lúcia M. B. Pereira; OLIVEIRA, Paulo Motta et alii (orgs.). Literatura, história e política em Portugal (1820-1856): Almeida Garrett, Alexandre Herculano, A. P. Lopes de Mendonça. Rio de Janeiro: Eduerj, 2007. pp.115-135. O bobo. Lisboa: Difel, 1967.

HERMANN, Jacqueline. No reino do desejado: a construção do sebastianismo em Portugal séculos XVI e XVII. São Paulo: Companhia das Letras, 1998.

HOBSBAWM, Eric J. A era dos impérios (1875-1914). $8^{\mathrm{a}}$ ed. Rio de Janeiro: Paz e Terra, 2003.

Nações e Nacionalismo desde 1780: programa, mito e realidade. $3^{\mathrm{a}}$ ed. Rio de Janeiro: Paz e Terra, 2002.

JUROMENHA, Visconde de. Obras de Luiz de Camões. Lisboa: Imprensa Nacional, 1861. vol 2.

KOTHE, Flávio R. O cânone imperial. Brasilia: UnB, 2000.

LEÃO, A. Carneiro. Nabuco e Junqueiro. Porto: Lello \& Irmão, 1953.

LEMOS, Miguel. Luís de Camoëns. Paris: Siège Central du Positivisme, 1880.

LIMA, Luiz Costa. A aguarrás do tempo: estudos sobre a narrativa. Rio de Janeiro: Rocco, 1989. 
1981.

Dispersa demanda: ensaios sobre literatura e teoria. Rio de Janeiro: Francisco Alves,

. "Documento e ficção". In: Sociedade e discurso ficcional. Rio de janeiro: Guanabara, 1986. pp.187-242.

Intervenções. São Paulo: Edusp, 2002.

Limites da voz (Montaigne, Schlegel, Kafka). 2a ed. Rio de Janeiro: Topbooks, 2005.

O fingidor e o censor: no Ancien Régime, no Iluminismo e hoje. Rio de Janeiro: Forense-Universitária, 1988.

LOURENÇO, Eduardo. O labirinto da saudade: psicanálise mítica do destino português. $7^{\mathrm{a}}$ ed. Lisboa: Gradiva, 2010.

LOURENÇO, Eduardo. Mitologia da saudade. São Paulo: Companhia das Letras, 1999. pp.54-64.

MACEDO, Francisco Ferraz de. Desabafo patriotico e o tricentenario de Camões no Rio de Janeiro. Rio de Janeiro: Typographia Academica, 1880.

MACHADO, Álvaro Manuel. A geração de 70: uma revolução cultural e literária. $3^{\mathrm{a}}$ ed. Lisboa: Ministério da Educação, 1986.

MAGALHÃES, Dr. Figueiredo. Camões e os portuguezes no Brasil: reparos criticos. Primeira parte. Rio de Janeiro: Typographia da Gazeta de Noticias, 1880.

MARTINS, Oliveira. Camões. Lisboa: Guimarães \& Cia, 1952.

MARTINS, Oliveira. História da civilização ibérica. Lisboa: Europa-América, [s.d.].

MARTINS, Wilson. A crítica literária no Brasil. $2^{\mathrm{a}}$ ed. Rio de Janeiro: Francisco Alves, 1983. vol. 1

MENDES, R. Teixeira. Discurso comemorativo do tricentenário de morte de Luís de Camões (10 de junho de 1880). Rio de Janeiro: Igreja Positivista do Brasil, 1977.

MIRANDA, José Américo. "Joaquim Nabuco, artista". In: $O$ eixo e a roda, Belo Horizonte, v. 19, n.2, p.33-56, jul-dez. 2010.

MIRANDA, José Américo \& DRUMMOND, Adriano Lima. "O alexandrino português". In: O eixo e a roda, Belo Horizonte, v. 14, n. 1, p.15-28, jan-jun. 2007.

MOISÉS, Massaud. Camões: lírica. São Paulo: Cultrix, 1968.

MOISÉS, Massaud. Dicionário de termos literários. São Paulo Cultrix, 2004.

MONTELLO, Josué. Um protesto a propósito de Camões. In: Os bonecos indultados. Rio de Janeiro: A Casa do Livro, 1973. pp.119-121. 
MOREIRA, Adriano. Teoria das relações internacionais. Lisboa: Almedina, 1999.

NABUCO, Carolina. A vida de Joaquim Nabuco. $5^{\mathrm{a}}$ ed. Rio de Janeiro: José Olympio, 1979.

NABUCO, Joaquim. A escravidão. Rio de Janeiro: Batel, 2010.

1906.

“A república é incontestável". In: Acervo digital da Fundação Joaquim Nabuco,

$<<$ http://digitalizacao.fundaj.gov.br/fundaj2/modules/visualizador/i/ult_frame.php?cod=1495

$>>$

- Camões e assumptos americanos: seis conferencias em universidades americanas.

São Paulo: Companhia Editora Nacional; Rio de Janeiro: Civilização Brasileira, 1940.

1872.

Camões e os lusíadas. Rio de Janeiro: Tipografia do Imperial Instituto Artístico,

. Discursos e conferências. Rio de Janeiro; Nova Iorque: Benjamin Aguila, 1911.

. Diários (1873-1910). $2^{\mathrm{a}}$ ed. Rio de Janeiro: Bem-Te-Vi, 2006.

. Escravos!: versos francezes a Epitecto. Rio de Janeiro: G. Leuzinger \& Filhos, 1886.

Escritos e discursos literários. L'option. São Paulo: Instituto Progresso, 1949.

. Joaquim Nabuco embaixador (1905-1907). Rio de Janeiro: Fundação Alexandre de

Gusmão, 2011. vol 1.

. Joaquim Nabuco embaixador (1908-1910). Rio de Janeiro: Fundação Alexandre de Gusmão, 2011. vol 2.

. Minha fé. Recife: Fundação Joaquim Nabuco; Massangana,1985.

. Minha formação. 10ª ed. Brasîlia: Universidade de Brasîlia, 1981.

Mr. Root and Peace: speech at the dinner given by the Peace Society of New York in

honor of Mr. Root on February 26, 1909. Rio de Janeiro: G. Leuzinger \& Filhos, 1909.

. “O abolicionismo". In: SANTIAGO, Silviano (coordenação seleção de livros e prefácios). Intérpretes do Brasil. Rio de Janeiro: Nova Aguilar, 2002. v.3. pp.3-167.

Pensées détachées et souvenirs. Paris: Hachette, 1906.

Um estadista do império. $5^{\mathrm{a}}$ ed. Rio de Janeiro: Topbooks, 1997. vol 1.

. Um estadista do império. $5^{\mathrm{a}}$ ed. Rio de Janeiro: Topbooks, 1997. vol 2.

NABUCO(a), Joaquim. "The place of Camoens in literature". Disponível no site da Cornell University Library: <<http://archive.org/details/cu31924027723059〉>

NABUCO(b), Joaquim. "Camoens, the lyric poet". Disponível no site da Cornell University Library: <<http://archive.org/details/cu31924027723059>>

NABUCO(c), Joaquim. "The Lusiads as epic of love". Disponível no site da Cornell University Library: <<http://archive.org/details/cu31924027723059>> 
NEVES, João Alves das. As relações literárias de Portugal com o Brasil. Lisboa, Instituto de Cultura e Língua Portuguesa; Ministério da Cultura, 1992.

NIETZSCHE, Friedrich. II consideração intempestiva sobre a utilidade e os inconvenientes da história para a vida. In: Escritos sobre história. Rio de Janeiro: PUC-RIO; São Paulo: Loyola, 2005. pp.67-178.

NOGUEIRA, Marco Aurélio. O encontro de Joaquim Nabuco com a política: as desventuras do liberalismo. Rio de Janeiro: Paz e Terra, 2010.

NUNES, Benedito. "Crítica literária no Brasil, ontem e hoje". In: MARTINS, Maria Helena (org). Rumos da crítica. $2^{\mathrm{a}}$ ed. São Paulo: Senac, 2007. pp.51-79.

OLIVEIRA, Paulo Motta. "De navegações e naufrágios: imagens de Portugal de Garrett a Pessoa". In: PEREIRA, Edgar; OLIVEIRA, Paulo Motta; PESSÔA DE OLIVEIRA, Silvana Maria. Intersecções: ensaios de literatura portuguesa. Campinas: Komedi, 2002. pp.69-162.

ORTIGÃO, Ramalho. "Luís de Camões". In: Figuras e questões literárias: perfis de escritores e problemas de estilo. Lisboa: A. M. Teixeira \& Cia, 1945. vol. I. pp.99-220.

PEIXOTO, Afrânio. Camões e o Brasil. Paris; Lisboa: Aillaud; Bertrand, 1928.

XIX.

Ensaios camonianos. Rio de Janeiro; São Paulo; Porto Alegre: Jackson, 1947. Vol.

PEREIRA, Paulo José dos Reis. A política externa da primeira república e os Estados Unidos: a atuação de Joaquim Nabuco em Washington (1905-1910). São Paulo: Fapesp; Hucitec, 2006.

PERRONE-MOISÉS, Leyla. "O lugar crítico". In: Texto, crítica e escritura. São Paulo: Ática, 1978. pp.15-34.

PIRES, Maria Lucilia Gonçalves. A crítica camoniana no século XVII. Lisboa: Instituto de Cultura e Língua Portuguesa; Ministério da Cultura e das Universidades, 1982.

QUADROS, António. A ideia de Portugal na literatura portuguesa dos últimos cem anos. Lisboa: Fundação Lusíada, 1989.

QUENTAL, Antero de. Poesia e prosa. São Paulo: Cultrix, 1974.

Prosas da época de Coimbra: Lisboa: Sá da Costa, 1973.

QUEIRÓS, Eça. A ilustre casa de Ramires. Cotia: Ateliê, 2000.

RAMALHO, Américo da Costa. Estudos camonianos. Coimbra: Instituto de Alta Cultura, 1975.

RENAN, Ernest. Qu'est-ce qu'une nation?. Paris: Mille et une nuits, 1997. 
RIBEIRO, Maria Aparecida. "Camões passado a limpo?: o poeta como personagem dramática no século XX". São Paulo: Actas da V Reunião Internacional de Camonistas, USP/FFLCH, 1987. p. 627-645.

RICUPERO, Bernardo. O romantismo e a idéia de nação no Brasil (1830-1870). São Paulo: Martins Fontes, 2004.

RODRIGUES, Marina Machado. Camões e os poetas do século XVI. Rio de Janeiro: Eduerj, 2006.

ROMERO, Sílvio. Teoria, crítica e história literária. Seleção e apresentação de Antonio Candido. São Paulo: EDUSP, 1977.

SALLES, Ricardo. Joaquim Nabuco: um pensador do Império. Rio de Janeiro: Topbooks, 2002.

SANDMANN, Marcelo Corrêa. As comemorações do tricentenário de Camões no Brasil. Revista Letras, Curitiba, n. 59, jan/jun. Editora UFPR, 2003. pp. 197-205.

SARAIVA, António José. A tertúlia ocidental: estudos sobre Antero de Quental, Oliveira Martins, Eça de Queiroz e outros. 2a ed. Lisboa: Gradiva, 1996.

Estudos sobre a arte d'Os Lusíadas. 2ª ed. Lisboa: Gradiva, 1996.

Luís de Camões. Lisboa: Europa-América, 1959.

SCHWARTZ, Roberto. Ao vencedor as batatas: forma literária e processo social nos inícios do romance brasileiro. São Paulo: Duas Cidade; 34, 2003.

SENA, Jorge de. A estrutura de "Os Lusíadas" e outros estudos camonianos e de poesia peninsular do século XVI. Lisboa: Portugália, 1970.

Trinta anos de Camões: 1948-1978 (estudos camonianos e correlatos). Lisboa: Edições 70, 1980. vol I.

SILVA, Joaquim Norberto de Sousa. Bosquejo da história da poesia brasileira. Belo Horizonte: UFMG, 1997.

SILVEIRA, Jorge Fernandes da. O Tejo é um rio controverso: António José Saraiva contra Luís Vaz de Camões. Rio de Janeiro: 7Letras, 2008.

SIMÕES, João Gaspar. "Biografia feita por Storck". In: Estudos sobre Camões: páginas do Diário de Notícias dedicadas ao poeta no $4^{\circ}$ centenário de sua morta. Lisboa: Imprensa Nacional - Casa da Moeda, 1981. pp.85-90. 
SODRÉ, Nélson Werneck. O naturalismo no Brasil. $2^{\mathrm{a}}$ ed. Belo Horizonte: Oficina de Livros, 1992.

SOUZA, Roberto Acízelo de. Introdução à historiografia da literatura brasileira. Série Ponto de Partida. Rio de Janeiro: Eduerj, 2007.

STORCK, Wilhelm. Vida e obras de Luís de Camões. Primeira parte. Lisboa: Typographia da Academia Real de Sciencias, 1898.

SÜSSEKIND, Flora. "Rodapés, tratados e ensaios". In: Papéis colados. $2^{\mathrm{a}}$ ed. Rio de Janeiro: UFRJ, 2002. pp.15-36.

TELES, Gilberto Mendonça. Camões e a poesia brasileira. 2a ed. São Paulo; Brasilia, Quíron; MEC: 1976.

TENGARRINHA, José (org.). História de Portugal. 2a . ed. São Paulo: EDUSC; UNESP; Instituto Camões, 2001.

VERDE, Cesário. O livro de Cesário Verde. $4^{\mathrm{a}}$ ed. Lisboa: Biblioteca Ulisseia de Autores Portugueses, [s.d.]

VERÍSSIMO, José. Teoria, crítica e história literária. Seleção e apresentação de João Alexandre Barbosa. São Paulo: EDUSP, 1977.

VIANA FILHO, Luis. A vida de Joaquim Nabuco. São Paulo: Martins/MEC, 1973.

VICHINSKY, Flávio Garcia. "Do mito Camões ao outro Camões de Saramago". Dissertação de mestrado. FFLCH/USP. São Paulo, 2008. 167p.

VIEIRA, Nelson H. Brasil e Portugal - a imagem recíproca: o mito e a realidade na expressão literária. Lisboa: Ministério da Educação, 1991.

WELLEK, René. História da crítica moderna: século XVIII. São Paulo: Herder; USP, 1967. vol. I. 